\title{
Het verzekeringsgeneeskundig handelen en de verzuimduur : een studie naar het handelen en de taakopvattingen van verzekeringsgeneeskundigen en met verzekeringsgeneeskundige taken belaste bedrijfsartsen in de regio Zuid-Limburg
}

Citation for published version (APA):

Kaiser, C. P. (1992). Het verzekeringsgeneeskundig handelen en de verzuimduur : een studie naar het handelen en de taakopvattingen van verzekeringsgeneeskundigen en met verzekeringsgeneeskundige taken belaste bedrijfsartsen in de regio Zuid-Limburg. [Doctoral Thesis, Maastricht University]. Datawyse / Universitaire Pers Maastricht. https://doi.org/10.26481/dis.19920618ck

Document status and date:

Published: 01/01/1992

DOI:

10.26481/dis.19920618ck

Document Version:

Publisher's PDF, also known as Version of record

Please check the document version of this publication:

- A submitted manuscript is the version of the article upon submission and before peer-review. There can be important differences between the submitted version and the official published version of record. People interested in the research are advised to contact the author for the final version of the publication, or visit the DOI to the publisher's website.

- The final author version and the galley proof are versions of the publication after peer review.

- The final published version features the final layout of the paper including the volume, issue and page numbers.

Link to publication

\footnotetext{
General rights rights.

- You may freely distribute the URL identifying the publication in the public portal. please follow below link for the End User Agreement:

www.umlib.nl/taverne-license

Take down policy

If you believe that this document breaches copyright please contact us at:

repository@maastrichtuniversity.nl

providing details and we will investigate your claim.
}

Copyright and moral rights for the publications made accessible in the public portal are retained by the authors and/or other copyright owners and it is a condition of accessing publications that users recognise and abide by the legal requirements associated with these

- Users may download and print one copy of any publication from the public portal for the purpose of private study or research.

- You may not further distribute the material or use it for any profit-making activity or commercial gain

If the publication is distributed under the terms of Article $25 \mathrm{fa}$ of the Dutch Copyright Act, indicated by the "Taverne" license above,

Download date: 26 Apr. 2023 


\section{HET VERZEKERINGSGENEESKUNDIG HANDELEN EN DE VERZUTMDUUR}

Een studie naar het handelen en de taakopvattingen van verzekeringsgeneeskundigen en met verzekeringsgeneeskundige taken belaste bedrijfsartsen in de regio Zuid-Limburg 



\section{HET VERZEKERINGSGENEESKUNDIG HANDELEN EN DE VERZUIMDUUR}

Een studie naar het handelen en de taakopvattingen wan verzekeringsgeneeskundigen en met verzekeringsgeneeskundige taken belaste bedrijfsartsen in de regio Zuid-Limburg

\section{PROEFSCHRIFT}

ter werkrijging van de graad wan doctor aan de Rijksuniversiteit Limburg te Maastricht, op gezag van de Rector Magnificus, Prof. Mr. M.J. Cohen, volgens het besluit van het College van Dekanen, in het openbaar te verdedigen op donderdag 18 juni 1992 , om 14.00 uur

door

Claude Paul Kaiser

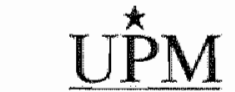




\section{Promotores:}

Prof. Dr. H. Philipsen

Prof. Dr. Tj. de Boorder

\section{Co-promotor:}

Dr. F.J.N. Nujhuis

\section{Beoordelingscommissie:}

Prof. Dr. J. van der Zee (voorzitter)

Prof. Dr. J.J.C.B. Bremer

Prof. Dr. F.J.H. van Dijk (Universiteit van Amsterdam)

Prof. Dr. E.P. de Jong (Gemeenschappelijk Administratiekantoor

Prof. Dr. F. Stumans

\section{Druk:}

Datawyse Maastricht / Krips Repro Meppel

CIP-GEGEVENS KONINKLIIKE BIBLIOTHEEK, DEN HAAG

Kaniser "Clude Paul

Het verzekeringsgeneeskundig handeten en de verzaimdlus: een studie nar het handelen en de takkopvattingen van verzokeringsgeneeskundigen en met verzakeringsgeneeskundige taken belaste bedrijfsartsen in de regiv Zuid-Limburg / Claude Paul Kaiser. - Maastricht

Universituire Pers Mastricht. - III.

Proefschrif Maastricht. - Met lit. opg. - Met samenvatting in het Engets.

ISBN 90-5278-028-5

NUGI 757

Trefw.: verzekeringsgeneeskunde / ziekteverzuim / arbeidsongeschiktheid 


\section{INHOUDSOPGAVE}

pag.

\section{VOORWOORD}

INLEIDING

1 HISTORIE

1.1 Historie van de arbeidsongeschiktheidswerzekeringen Nederland 5

1.2 Historische ontwikkeling van het ziekteverzuim in Nederland 9

1.2.1 Statistische ontwikkelingen $\quad 10$

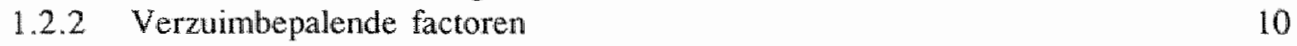

$\begin{array}{lll}\text { 1.2.3 De maatschappelijke context } & 15\end{array}$

1.2.4 De invloed van de curatieve gezondheidszorg op arbeidsongeschiktheid 16

$\begin{array}{lll}\text { 1.3 De uitvoeringsorganisaties } & 17\end{array}$

$\begin{array}{ll}\text { 1.3.1 Uitwoeringsorganisaties sociale verzekeringen } & 17\end{array}$

$\begin{array}{ll}\text { 1.3.2 De uitvoering van de ziektewet } & 19\end{array}$

1.3.3 Uitwoeringsorganisatie ten behoeve van ambtenaren $\quad 22$

$\begin{array}{lll}\text { 1.3.4 Naamgeving artsen } & 23\end{array}$

1.4 De taak van de verzekeringsgeneeskundige $\quad 24$

$\begin{array}{lll}1.4 .1 & \text { Inleiding } & 24\end{array}$

1.4.2 De verzekeringsgeneeskundige beoordeling 27

1.4.3 Verzekeringsgeneeskunde in de dagelijkse praktijk 27

1.5 De taak van de bedrijfsarts/verzekeringsgeneeskundige in de uitvoeringsorganisaties 31

1.5.1 Taken bedrijfsarts/verzekeringsgeneeskundige bij de uitvoering van de $\begin{array}{ll}\text { ziektewet } & 32\end{array}$

1.5.2 Taken bedrijfsarts/verzekeringsgeneeskundige bij de uitwoering van de
ambtenarenwet en additionele regelingen

1.6 Probleembespreking $\quad 32$

2 LITERATUURONERZICHT EN PROBLEEMSTELLING

$2.1 \quad$ Inleiding

$\begin{array}{lll}2.2 & \text { Literatuuroverzicht } & 37\end{array}$ 
2.3 De rol van de verzekeringsgeneeskundige in het verzuim

2.4 Probleemstellingen

3 ONDERZOEKSOPZET

3.1 De artsen

3.2 De patiënten

3.2.1 Selectie door instellingen

3.2.2 Uitvoering van het onderzoek door de instellingen

3.3 Gegevensverzamelingen

3.3.1 Kenmerken van artsen 58

3.3.2 Taakopvattingen van artsen $\quad 58$

3.3.3 Het verzekeringsgeneeskundig handelen $\quad 59$

3.3.4 Kenmerken van patiënten $\quad 60$

4 TAAKOPVATTINGEN 61

4.1 Inleiding 61

4.2 Vragenlijsten $\quad 62$

4.2.1 Het concjpiëren van taakinhoudelijke variabelen: een modelbeschrijving 62

4.2.2 Constructie van de taakinhoudsvariabelen 64

4.2.2.1 Factor- en betrouwbarheidsanalyse $\quad 64$

4.2.2.2 Beschrijving van de taakinhoudelijke variabelen 65

$\begin{array}{ll}\text { 4.3 Analyse taakopvattingen: resultaten } & 74\end{array}$

$\begin{array}{lll}4.3 .1 & \text { Verschillen in takopvatting } & 74\end{array}$

4.3.2 Onderscheid tussen verzekeringsgeneeskundige, bedrijfsarts/verzekerings$\begin{array}{ll}\text { geneeskundige en bedrijfsarts } & 75\end{array}$

4.3.2.1 Onderscheid tussen verzekeringsgeneeskundige en bedrijfsarts 76

4.3.2.2 Onderscheid tussen verzekeringsgeneeskundige en bedrijfsarts/verzekeringsgeneeskundige $\quad 77$

4.3.2.3 Onderscheid tussen bedrijfsarts/verzekeringsgeneeskundige en bedrijfsarts 78

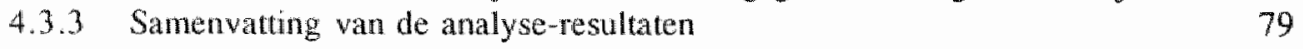

4.4 Constructie van takinhoudsvariabelen ten behoeve van de effectmeting $\quad 80$ 
$5.1 \quad$ Inleiding

5.2 Beschrijving van de artsen- en patiëntenpopulaties

5.2.1 Artsenpopulatie

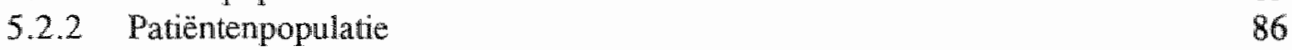

5.2.3 Kenmerken van de onderzoekspopulaties 90

5.3 Verschillen in begeleiding tussen verzekeringsgeneeskundige en bedrijfs arts/verzekeringsgeneeskundige

5.3.1 Verschillen in arbeidsongeschiktheidsduur

5.3.2 Verschillen in begeleidingsactiviteit

5.3.3 Verschillen in oordeelsvorming

5.4 Analyse-resultaten

5.4.1 De onafhankelijke variabele: wachttijd, in relatie tot de ao-duur 101

5.4.2 De onafhankelijke variabelen

5.4.3 De correlatie tussen de arbeidsongeschiktheidsduur en de onafhankelijke variabelen: onderzoekspopulatie

106

5.4.4 De multiple regressie-analyse: onderzoekspopulatie

107

5.4.4.1 Inleiding

107

5.4.4.2 Multiple regressie-analyse: stapsgewijs

108

5.4.4.3 Multiple regressie-analyse met groepen variabelen

109

5.4.5 De diagnosegroepen

5.4.5.1 De correllatie tussen ao-duur en de onafhankelijke variabelen in de verschillendle diagnosegroepen

5.4.5.2 Multiple regressie-analyse: diagnosegroepen

5.5. Bespreking van de analyse-resultaten

5.5.1 Verschillen in begeleiding tussen verzekeringsgeneeskundige en bedrijfsarts/verzekeringsgeneeskundige

5.5.2 De relatie tussen wachttijd en arbeidsongeschiktheidsduur

5.5.3 De relatie tussen variabelen en arbeidsongeschik theidsduur

5.5.3.1 De correlatie tussen variabelen en arbeidsongeschiktheidsduur

5.5.3.2 De multiple regressie-analyse

6 SLOTBESCHOUWING: ONDERZOEKSRESULTATEN IN SOCIAALVERZEKERINGSGENEESKUNDIG PERSPECTIEF

6.1 Reikwijdte en beperkingen van het onderzoek 
6.4 Verschillen in begeleiding tussen verzekeringsgeneeskundigen en bedrijfsarts/verzekeringsgeneeskundigen

$\begin{array}{ll}6.4 .1 & \text { De begeleiding en oordeelsvorming } \\ 6.4 .2 & 128\end{array}$

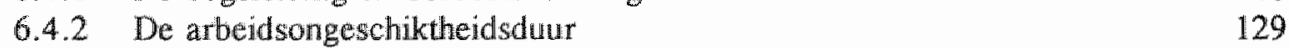

6.4.3 Samenvatting van de resultaten 132

6.5 De maatschappelijke relevantie 133

$\begin{array}{ll}\text { SUMMARY } & 139\end{array}$

$\begin{array}{lr}\text { SAMENVATTING } & 145\end{array}$

$\begin{array}{ll}\text { LTTERATUUR } & 151\end{array}$

\section{BULAGEN}

$1 \quad$ Overzicht sociale verzekeringswetten in Nederland in $1989 \quad 161$

2 Overzicht bedrijfsverenigingen naar administratiewijze 164

3 Taakopvattingen, overzicht vragenclusters 165

$4 \quad$ Statistische kenmerken taakopvattingsclusters 170

$5 \quad$ Overzicht van de in onderzoek betrokken diagnosen 171

6 Statistische kenmerken beoordelingsitems verzekeringsgeneeskundigen $\quad 176$ en bedrijfsartsen/verzekeringsgeneeskundigen

7 Correlatie tussen onafhankelijke variabelen en ao-duur en onafhankelijke 177 variabelen onderling

CURRICULUM VITAE 


\section{VOORWOORD}

Velen ben ik dank verschuldigd voor hun medewerking, ondersteuning en begrip, die ze mij direct of indirect gegeven hebben bij de totstandkoming van dit proefschrift. Dit geldt in de eerste plaats voor mijn promotores Prof. Dr. H. Philipsen, prof. Dr. Tj. de Boorder en Dr. F.J.N. Nijhuis. Zij waren, ieder op hun eigen wijze, een belangrijke en onmisbare steun in de nug.

Prof. Philipsen, die de voortgang bewaakte en eerdere versies van dit proefschrift methodologisch van commentaar voorzag; Prof, de Boorder, die mij stimuleerde tot dit onderzoek en mij in alle fasen ondersteunde, en Dr. Nijhuis, die mij kritisch en collegiaal ondersteund en gestimuleerd heeft bij de analyses en het schrijven van dit proefschrift.

Voorts ben ik dank verschuldigd aan de referenten voor de wijze, waarop zij dit proefschrift van commentaar voorzagen. Prof. Dr. J.J.C.B. Bremer voor zijn zeer nauwgezette taalkundig commentaar; Prof. Dr. J. van der Zee voor zijn kritische opmerkingen en adviezen ten aanzien de analyses; prof. Dr. F.J.H. van Dijk voor zijn aanwijzingen ten aanzien van de onderzoeksresultaten; Prof. Dr. E.P. de Jong voor zijn aanwijzingen bij de historische ontwikkeling van de Sociale Zekerheid en Prof. Dr. F. Surmans voor zijn methodologische kanttekeningen.

Het onderzoek naar het verzekeringsgeneeskundig handelen kon alleen worden worden uitgevoerd dankzij de uitstekende samenwerking met de vakgroep arbeidsgeneeskunde van de Rijksuniversiteit Limburg. Voor de opzet van het onderzoek en uitvoering van het veldwerk ben ik vee] dank verschuldig aan Dr. L. Vermeer. Een groot deel van de statische verwerking werd uigevoerd door J. Slangen.

Mijn dank geldt ook het Gemeenschappelijk Administratiekantoor, dat mij in staat heeft gesteld dit onderzoek naast mijn normale werkzaamheden te verrichten. In het bijzonder geldt dit voor W. van Erk-Jansen, die een deel van het veldwerk, het coderen en de gegevensverwerking heeft verzorgd. Van groot belang is de wijze geweest, waarop de medewerksters van het GAK-districtskantoor Den Haag mij de gelegenheid hebben gegeven dit proefschrift te schrijven.

Dit onderzoek zou onmogelijk geweest zijn zonder de medewerking van de respondenten, die tijdens hun normale werk uitgebreide vragenlijsten moesten invullen, en de arbeidsorganisaties, die hen daartoe in staat hebben gesteld.

Tot slot zijn er de vele bekenden en familie, die het mij mogelijk hebben gemaakt mij te onttrekken aan delen van mijn maatschappelijke en huishoudelijke verplichtingen. Vaak werd mij de vraag gesteld: is jouw boek nu eindelijk klaar? Het antwoord heeft $\mathrm{u}$ in de hand.

's-Gravenhage, 1992 



\section{INLEIDING}

De omvang van het ziekteverzuim in Nederland en met name het grote aantal langdurig arbeidsongeschikten, dat zich bijna onstuitbaar in de richting van de eérn miljoen lijkt te bewegen, wordt momenteel algemeen beschouwd als een maatschappelijk probleem van de eerste orde.

Sedert het eind van de jaren vijftig richtten steeds meer onderzoekers zich op de problematiek van het ziekteverzuim, op zoek naar determinanten die van invloed zijn op het ziekteverzuim en naar aangrijpingspunten om het ziekteverzuim te beheersen en te verminderen.

Deze inspanningen leidden tot nauwkeuriger definities van ziekteverzuim en deden begrippen als zwart, wit en grijs verzuim, verzuimbehoefte, verzuimnoodzaak, verzuimgelegenheid en verzuimmogelijkheid ontstaan, waarmee tevens wordt aangegeven dat ziekteverzuim bepaald wordt door meer factoren dan ziekte alleen.

Het inzicht in de verzuimveroorzakende en verzuimbeïnvloedende factoren is in deze periode aanzienlijk vergroot door onderzoeken die zich veelal richtten op de arbeidsbelasting, de arbeidsomgeving en de mogelijkheden tot bijstelling ervan, de sociaal-culturele en sociaal-economische omstandigheden. Met name is veel onderzoek gedaan naar de relatie tussen arbeidsongeschiktheid en arbeidsomstandigheden, evenals naar de opvattingen van patiënten over arbeidsongeschiktheid. Ook het stelsel van sociale zekerheid is onderzocht op zijn verzuimbeperkende en verzuimbevorderende werking (Buys, 1985).

Merkwaardigerwijs blijft de werkwijze van de uitvoeringsorganisaties sociale verzekeringen en met name de rol van de medicus bij de uitvoering van de arbeidsongeschiktheidswetten grotendeels buiten beschouwing. Wel wordt regelmatig de vraag gesteld welke invloed de medicus - in casu de verzekeringsgeneeskundige - heeft op het verzuim. Soms bestaat zelfs de indruk dat deze invloed in bepaalde situaties wel eens verzuimverlengend kan zijn (Soeters, 1983).

Dit vormt voldoende reden om de vraag te stellen: wat doen verzekeringsgeneeskundigen in de dagelijkse praktjjk en wat is de invloed van hun handelen op het ziekteverzuim. Immers, zeker het langdurig ziekteverzuim wordt op de een of andere wijze gelegitimeerd door artsen.

Dit onderzoek richt zich specifiek op de samenhang tussen enerzijds het handelen van verzekeringsgeneeskundigen ( $\mathrm{vg}$ ' $\mathrm{n}$ ) en wan bedrijfsartsen, die met verzekeringsgeneeskundige taken belast zijn (de bedrijfsarts/verzekeringsgeneeskundigen, ba/vg" $\mathrm{n}$ ) en anderzijds de arbeidsongeschiktheidsduur.

Het onderzoek naar het handelen van verzekeringsgeneeskundigen en met verzekeringsgeneeskundige taken belaste bedrijfsartsen is uitgevoerd in de jaren 1986-1988 in de regio Zuid-Limburg. Aan het onderzoek namen 35 verzekeringsgeneeskundigen (vg'n) en bedrijfsarts/verzekeringsgeneeskundigen (ba/vg'n). Het handelen van deze 35 
vg' $n$ en ba/vg' $n$ is in kaart gebracht aan de hand wan de registratie van de begeleiding van 480 arbeidsongeschikten vanaf de $4 \mathrm{e}$ arbeidsongeschiktheidsweek $\mathrm{t} / \mathrm{m}$ de $9 \mathrm{e}$ arbeidsongeschiktheidsmaand. De door deze artsen begeleide arbeidsongeschikten zijn. woonachtig in Midden-en Zuid-Limburg.

Alvorens het onderzoek te beschrijven wordt in hoofdstuk 1 een overzicht gegeven van de historische ontwikkeling van de arbeidsongeschiktheidsverzekeringen en het ziekteverzuim in Nederland, alsmede van het ontstaan van de huidige inrichting van de uitvoeringsorganisaties op het terrein van de arbeidsongeschiktheidsverzekeringen.

Hoofdstuk 2 bevat een owerzicht van de relevante literatuur. Hierbij valt op, dat ondanks het feit dat ziekteverzuim al sedert het midden van de jaren vijftig in de belangstelling staat, er betrekkelijk weinig literatuur beschikbaar is over (het effect van) het handelen van verzekeringsgeneeskundigen. Bovendien wordt de bruikbaarheid wan de beschikbare buitenlandse literatuur beperkt door de grote verschillen tussen de sociale stelsels in de westerse industrielanden. Een vergelijking met de Nederlandse situatie is hierdoor moeilijk.

Het registreren van het handelen van vg'n en ba/vg'n, het vaststellen van verschillen in handelen en het in kaart brengen van de relatie tussen het handelen en de verzuimduur levert niet zonder meer handvatten woor een betere beheersing van het verzuim.

Hiervoor is het nodig inzicht te hebben in de factoren, die invloed hebben op het handelen van de artsen, in de beïnvloedbaarheid van deze factoren alsmede in het effect van het handelen op de verzuimduur. In dit onderzoek worden de kenmerken van artsen, patiënten en uitvoeringsorganisaties beschreven; bij de analyses worden deze kenmerken als onafhankelijke variabelen ingevoerd. De onderzoeksopzet is beschreven in hoofdstuk 3.

Specifieke aandacht is in dit verband besteed aan de taakopvattingen van artsen. Het is bekend dat taakopvattingen invloed hebben op het handelen van mensen. Evenwel, literatuuronderzoek leert dat systematisch onderzoek naar taakopvattingen bij verzekeringsgeneeskundigen niet eerder heeft plaatsgevonden. Bij huisartsen zijn taakopvatlingen al geruime tijd onderwerp van onderzoek (Sluijs, Dopheide en Van der Zee, 1985). De in dergelijke onderzoeken gehanteerde taakopvattingensmodellen en het daarbij ontwikkelde instrumentarium zijn niet zonder meer toepasbaar op vg'n en ba/ $v g$ 'n.

Dit betekent dat ten behoeve van het construeren van taakopvattingsvariabelen nader onderzoek naar de taakopvattingen van vg'n en ba/vg'n verricht moet worden. Dit deel van het onderzoek, beschreven in hoofdstuk 4, beperkt zich niet tot vg'n en ba/vg'n, maar strekt zich uit bedrijfsartsen. Bedrijfsartsen nemen wat de taakopvattingen betreft een vergelijkbare positie in ten opzichte van de $\mathrm{vg}$ en ba/vg. Daar zij geen verzekeringsgeneeskundige taken hebben, kunnen zij niet in het hoofdonderzoek (relatie tussen handelen en ao-duur) betrokken worden. Om die reden is hun deelname aan het onderzoek beperkt tot het onderzoek naar taakopvattingen. 
Hoofdstuk 4, Taakopvattingen, bestaat uit 2 delen:

1. het onderzoek naar de taakopvattingen van $v g^{\prime \prime} n, b a / g^{\prime \prime} n$ en ba'n en het vaststellen van de verschillen in taakopvattingen tussen deze categorieën artsen, en

2. het construeren van taakopvattingsvariabelen ten behoeve wan het onderzoek naar de samenhang tussen de arbeidsongeschiktheidsduur en onder andere de taakopvattingen

De onder 2. genoemde taakopvattingsvariabelen zijn als onafhankelijke variabelen gebruikt bij de in hoofdstuk 5 beschreven analyses van de samenhang tussen het handelen van $v g / n$ en ba/vg'n en de arbeidsongeschiktheidsduur.

In hoofdstuk 5, Resultaten, is de correlatie tussen wachttijd en arbeidsongeschiktheidsduur (ao-duur) beschreven, gevolgd door de analyse van de samenhang tussen ao-duur en onafhankelijke variabelen. Onder wachttijd wordt verstaan de periode tussen de ziekmelding en de start van de verzekeringsgeneeskundige begeleiding: het eerste spreekuurbezoek aan de verzekeringsgeneeskundige of bedrijfsarts/verzekeringsgeneeskundige.

Hoofdstuk 6 bevat de slotbeschouwing, waarin de onderzoeksresultaten in een sociaalverzekeringsgeneeskundig perspectief worden geplaatst. Dit hoofdstuk bevat naast de belangrijkste conclusies van dit onderzoek ook aanbevelingen ten aanzien van de verzekeringsgeneeskundige begeleiding en de inrichting van de uitvoeringsorganisaties sociale verzekeringen in het licht van het volumebeleid sociale verzekeringen. 



\subsection{Historie van de arbeidsongeschiktheidsverzekeringen Neder- land}

Het moment, waarop de sociale regelingen en arbeidsongeschiktheidsregelingen in Nederland zijn ontstan, is niet exact aan te geven. In deze paragraf is dankbaar gebruik gemaakt van de studie van Abram de Swaan, getiteld: Zorg en de Staat, waarin het ontstaan en de ontwikkeling van sociale regelingen in Europa uitvoerig zijn beschreven en waaraan de verdere uiteenzetting voor een deel is ontleent.

De ontwikkeling van wat heden ten dage "de sociale zekerheid" heet, heeft zijn wortels in de tweede helft van de $18 \mathrm{e}$ eeuw, toen de toenemende macht van de burgers zichtbaar werd. Het meest direct kwam dit tot uniting in de Franse revolutie.

Zij leidde tot een definitieve wijziging van de machtsverhoudingen, allereerst in Frankrijk, in de volgende eeuw ook in andere Europese landen. De macht van de burgers nam toe evenals de macht van de door burgers vertegenwoordigde staat.

Vanaf het begin van de $19 \mathrm{e}$ eeuw zijn een tweetal ontwikkelingen op het gebied van sociale zekerheid zichtbaar: het ontstaan van regelingen voor staatsdienaren en het ontstaan van regelingen voor werkenden in het vrije bedrij. Deze ontwikkelingen kunnen naar thu ontstaansmoment en ontstaanshistorie als gescheiden ontwikkelingen worden beschouwd. Echter, er blijkt ook een zekere mate van overeenkomst te zijn wat betreft de verschuiving van taken van de individuele werkgever naar de staat. Tot op de dag van vandaag kan men constateren dat de regelingen voor ambtenaren en werknemers in de private sector verschillen; zowel in de uiteindelijke prestaties (bijvoorbeeld de waardevastheid wan pensioenen) als in de bijdrage, die van de individuele werknemer of ambtenaar gevraagd worden (lagere premie, premie-vrije verzekeringen).

De toenemende macht en invloed van de "burgerlijke staat." leiden tot toenemende taken en regelgeving wan staatswege. De groeiende behoefte aan geschoolde en loyale ambtenaren met name voor vitale staatstaken leidt in het begin van de 190 eeuw tot het ontstaan van pensioenregelingen voor staatsdienaren. De eerste pensioen-regeling in Nederland betrof de belastingambtenaren, wier pensioen in een algemeen besluit werd vastgelegd (1802). Betrof dit algemeen besluit uitsluitend de belastingambtenaren, in 1814 kwam er een "Reglement voor burgerlijke ambtenaren in algemene dienst van de Staat". Deze regeling onderging in de daaropvolgende jaren verschillende uitbreidingen, waarbij onder andere premievrijdom werd verleend. Dit leidde in 1836 tot de inwoering van het "Reglement op het Algemeen Burgerlijk Pensioenfonds", hetwelk in 1846 verwangen werd door een wettelijke regeling. Was deze wet aanwankelijk alleen van toepassing woor rijksambtenaren, later werden ook provincie-ambtenaren, leerkrachten in het openbaar onderwijs en gemeenteambtenaren onder de werking van deze 
wet gebracht (1913). De regelingen kenden echter voor de verschillende groepen ambtenaren grote verschillen. In de jaren na 1913 werd getracht een uniformering tot stand te brengen, hetgeen leidde tot de Pensioenwet (1922), waarin het merendeel van de toentertijd bestaande regelingen werd samengebracht. Deze Pensioenwet heeft gegolden tot 1966, in welk jaar de Algemeen Burgerlijke Pensioenwet in werking trad. Deze wet voorziet onder andere in verstrekking van pensioenen ingeval van blijvende arbeidsongeschiktheid en ouderdom.

\section{Sociale zekerheid ókk voor werknemers}

In de loop van de tweede helft van de $19 \mathrm{e}$ eeuw ontstonden de eerste geluiden om ook voor werknemers in het bedrijfsleven sociale regelingen te treffen. Aanvankelijk betrof dit regelingen voor hoger-geschoolden, die voor het bedrijf van essentieel belang waren. De toenemende industrialisering leidde tot een groeiend aantal industriële werkers. Waar de burgerij profiteerde van een toenemende welvaart, werd de samenleving geconfronteerd met een steeds omvangrijker verpauperd proletariaat, dat de volstrekte afhankelijkheid van en uitbuiting door de werkgevers afwees. Vanuit zedelijkheidsoverwegingen ontstonden bewegingen, die hun oorsprong vonden in de verschillende geloofsrichtingen en levensovertuigingen en tot doel hadden geldelijke of materiële ondersteuning te bieden aan armen. Op initiatief van individuele werkgevers ontstonden regelingen die het bestaan van werknemers beoogden te verbeteren.

De eerste nationale en verplichte verzekering tegen inkomstenderving ontstond in het Duitsland van keizer Wilhelm en werd tot stand gebracht onder het bij uitstek autoritaire regime van Bismarck. Zo ontstonden de wet op de ziekteverzekering (1883), die voorzag in medische hulp én ziekengeld, de ongevallenwet (1884) en de invaliditeitsverzekering (1899). De doorbraak in Groot-Brittannië kwam 25 jaar later met de invoering van de Pensioenwet (1908), gevolg door ziekte- en werkloosheidswetten.

Frankrijk volgde in 1930 met de totstandkoming van een nationaal stelsel.

De ontwikkeling van een nationale en verplichte verzekering in Nederland kwam, evenals in Frankrijk, betrekkelijk traag tot stand. Tot de eerste overheidsmaatregelen in Nederland behoren de maatregelen ter beperking van onder andere kinder- en vrouwenarbeid. Een voorbeeld hierwan is het zogenaamde kinderwetje van Van Houten (1874).

De totstandkoming van deze wet op de kinderarbeid en de kritiek op de naleving ervan zijn mede een verdienste van Coronel (Bergink, 1960). Coronel vroeg in zijn functie van stadsgeneesheer te Middelburg in zijn boek, getiteld "Middelburg, voorheen en thans", aandacht voor de nadelige gevolgen van de armoede voor de lichamelijke en geestelijke gezondheid van het volk. Na zijn benoeming tot stadsgeneesheer te Amsterdam vestigde hij de aandacht op de ongebreidelde en ongeordende industrialisering als belangrijkste ziekteoorzaak.

Mede op grond van zijn rapportages over de slechte naleving van de Kinderwet drong de toenmalige Nederlandsche Maatschappij ter bevordering der Geneeskunst bij het 
Parlement aan op maatregelen, hetgeen leidde tot de eerste parlementaire enquête.

De opdracht van deze parlementaire enquête betrof naast onderzoek naar de naleving van de Kinderwet ók onderzoek naar de toestand in fabrieken en werkplaatsen met het oog op de veiligheid, gezondheid en het welzijn der werklieden.

Dit betekende een krachtige impuls voor het op gang komen van de sociale en arbeids: wetgeving: de Arbeidswet (1889) en de Veiligheidswet (1895) zagen het licht. In 1890 werd de Arbeidsinspectie opgericht, die in 1903 uitgebreid werd met artsen (Geers, 1988).

De toenemende invloed van de arbeidersbeweging, op zoek naar nieuwe organisatievormen en bestaanszekerheid voor de arbeiders, leidde tot de roerige eerste decennia van de 20 e eeuw. Angst voor rewolutie bij wat toen de "bibber-bourgeoisie" genoemd werd, was groot (De Galan en Windmuller, 1974) en leidde tot incorporatie van de arbeidersklasse in nieuwe machtstructuren. Het ontstaan van politieke partijen en vakverenigingen als weerspiegeling van toenemende macht van de arbeiders was een sterke stimulans tot het ontstaan van sociale verzekeringswetten, die de bestaanszekerheid van de arbeiders trachten te vergroten.

\section{De arbeidsongeschiktheidswetten}

In 1901 werd de Ongevallenwet ingevoerd, gevolgd door de Invaliditeitswet in 1913 (Geers, 1988). Zowel de Ongevallenwet als de Invaliditeitswet waren verplichte verzekeringen. Naast het voorzien in inkomen bij invaliditeit kenden zij de mogelijkheid tot het verstrekken van geneeskundige behandeling. De bij deze wet vastgestelde invaliditeitsrenten waren niet welvaartsvast, hetgeen leidde tot vele tussentijdse aanpassingen. Op 1 januari 1963 werd ter vervanging van de Invaliditeitswet de Interimwet invaliditeitstrekkers ingevoerd, die een welvaartsvaste uitkering kende.

$\mathrm{Na}$ een parlementaire behandeling, die zich uitstrekte over een periode van \pm 25 jaar, werd in 1930 de Ziektewet ingevoerd. Deze wet verzekerde werknemers of daarmee gelijkgestelden tegen de geldelijke gevolgen van arbeidsongeschiktheid voor de laatstelijk verrichte arbeid ten gevolge van ziekte of gebrek gedurende maximaal 1 jaar.

De huidige Ziektewet, waarin de toenmalige Ongevallenwet is opgegaan, voorzlet in een uitkering die gelijk staat met $70 \%$ van het dagloon ingaande de derde arbeidsongeschiktheidsdag. Veelal wordt de uitkering door de werkgever aangevuld tot $100 \%$. De verzekering dekt ook de dagen dat een vrouwelijke werknemer afwezig is wegens zwangerschap of bevalling.

Op 1 juli 1967 werd, ter vervanging van de Interiminvaliditeitswet en de Invaliditeitswet, de Wet op de Arbeidsongeschiktheidsverzekering (WAO) ingevoerd. Het werkingsgebied van de WAO bleef beperkt tot werknemers. Op 1 oktober $1976 \mathrm{kwam}$ er een volksverzekering: de Algemene Arbeidsongeschiktheidswer (AAW).

De Wet op de Arbeidsongeschiktheidsverzekering (WAO) geldt voor werknemers die langer dan 52 weken arbeidsongeschikt zijn voor in billijkheid op te dragen arbeid; de hoogte van de uitkering is afhankelijk van het loon (met een maximum) en de mate van arbeidsongeschiktheid. 
De Algemene Arbeidsongeschiktheidswet (AAW) geldt woor alle ingezetenen wan her Koninkrijk der Nederlanden tussen de 18 en 65 jaar, voorzover zij loonvormende arbeid verrichten: voor werknemers (in loondienst werkenden in private ondernemingen of in overheidsdienst) als voor zelfstandigen. Zij voorziet in een uitkering op minimumniveau in geval van arbeidsongeschiktheid voor in billikheid op te dragen arbeid. De hoogte vin de uitkering is onafhankeliyk van de hoogte wan het inkomen van de uitkeringsgerechtigde, maar wel afhankelijk van do burgerlijke status en gezinssituatie. Recht op een uikkering krachtens deze wet ontstaat na een arbeidsongeschiktheidsduur van 52 weken.

Naast een werzekering tegen de geldeljke gevolgen van Jangdurige arbeidsongeschiktheid kent de AAW mogelijkheden tot het verstrekken van voorzieningen ter bevordering wan de terugkeer in het arbeidsproces en ter werbetering van de leefomstandigheden. Hieronder vallen voorzieningen als aanpassingen van de arbeidsplek, het verstrekken van hulpmiddelen (rolstoelen, aangepaste automobielen etc.) en dieet- en taxikostenvergoedingen.

Een aantal arbeidsverhoudingen wordt niet als dienstbetrekking beschouwd woor de werknemerswerzekering. Het betreft hier woornamelijk overheidspersoneel, te onderscheiden in ambtenaren (inclusief het personeel werkzaam in het (bijzonder) onderwijs), militairen en spoorwegpersoneel. De arbeidsverhoudingen voor de ambtenaren zijn vastgelegd in verschillende Ambtenarenreglementen. Deze reglementen voorzien onder andere in een loondoorbetaling lijdens ziekte.

Op 1 januari 1966 trad de Algemene Burgerlijke Pensioenwet (ABP-wet) in werking. In deze wet is, in aanvulling op de Pensioenwet (1922), naast het ouderdomspensioen ook het invaliditeitspensioen voor ambtenaren geregeld.

De uitvoering van de arbeidsongeschiktheidswetten voor werknemers in de private sector is opgedragen aan zogenaande "bedrijfsverenigingen". Ten behoeve van de medische advisering in het kader van de ziektewet maken deze in de regel gebruik van een eigen medische dienst. De medische advisering in het kader van de $A A W / W A O$ is opgedragen aan de Gemeenschappelijk Medische Dienst (GMD).

De uitvoering van de arbeidsongeschiktheidsregelingen woor ambtenaren is opgedragen aan de werkgever. Deze regelingen vinden hum basis in de ambtenarenwet en de verschillende rechtspositionele reglementen, zoals het Algemeen Rijksambtenarenreglement (ARAR) en werschillende gemeentelijke en andere reglementen. Ter medische advisering in geval wan vermoedelijk tijdelijke arbeidsongeschiktheid moet de werkgever gebruik maken van een door de minister erkende dienst: de Rijks Bedrijfsgezondheidsen Bedrijfsveiligheidsdienst (RBB, voorheen RGD), een gemeentelijke of districtsgezondheidsdienst, een bedrijfsgezondheidsdienst of een daartoe gecontracteerde arts.

In geval van blijvende gehele of gedeeltelijke arbeidsongeschiktheid kan de werkgever een beroep doen op de ABP-wet. Deze wet bepaalt onder andere dat de advisering ten aanzien van blijvende gehele of gedeeltelijke arbeidsongeschiktheid en de nitkerings- 
en voorzieningsmogelijkheden die daamee samenhangen is opgedragen aan hot Algemeen Burgerlikk Pensioenfonds (ABP).

De uitvoering wind plats op de Bedrijsenheid Arbeidsongeschiktheidsverzekening $(A O V)$, waarvan de medische dienst deel uitmaakt. De taak van de AOV is te vergelijken met de taken van de Bedrijfsverenigingen (het verlenen van witkeringen en verstrekken van voorzieningen) én de Gemeenschappelijk Medische Dienst (het adviseren ten aanzien van arbeidsongeschiktheid, herplaatsbaarheid en voorzieningen).

Het onderhavige onderzoek beperkt zich tot de uitvoering van de begeleiding van arbeidsongeschikten gedurende de eerste negen maanden van arbeidsongeschiktheid, zoals uitgevoerd door $\mathrm{gg}^{\mathrm{n}} \mathrm{n}$ en ba/vg' $\mathrm{n}$ in dienst van of werkend namens de bedrijfsverenigingen (werknemers in de private sector), de Rijks Bedrifsgezondheids- en Bedrijfsveiligheidsdienst (RBB) en vergelijkbare diensten ten behoeve van ambtenaren.

\subsection{Historische ontwikkeling van het ziekteverzuim in Nederland}

De bespreking van de historische ontwikkeling van het ziekteverzuim beperkt zich in het kader van dit onderzoek tot de periode nà de tweede wereldoorlog.

Deze keuze is niet zozeer gemaakt ondat de ontwikkeling van het ziekteverzuim in de eerste helft van deze eeuw niet van belang zou zijn, maar ondat het huidige stelsel wan sociale verzekeringswetten en uitvoeringsorganisaties pas in de jaren vijftig zijn huidi ge vorm heeft gekregen. Onder invloed van deze wetgeving ontstond binnen de uitvoeringsorganisaties de behoefte aan artsen met kennis van sociale verzekeringswetten en inzicht in de oorzaken van arbeidsongeschiktheid en ziekteverzuim. Aanvankelijk hadden de met de witvoering van de arbeidsongeschiktheidswetten belaste artsen een wnl. op controle gerichte taak. $\mathrm{Zij}$ ontlenen hieraan de tot op heden onuitroeibaar gebleken benaming: controle-arts. In de loop der jaren is het accent echter verschoven wan controle naar reintegratie en zeer recent ook naar preventie. Daarmee evolueerde de toenmalige controle-arts tot de huidige vg. Onderzock naar het handelen van vg'n en ba/vg'n zou, indien het onderzoek zich uitstrekte tot de periode vóór 1940, op grond varn werschillen in wetgeving en uitvoering geen vergelijking met het huidige verzekeringsgeneeskundig handelen toelaten.

Alvorens in te gaan op de historie van het ziekteverzuim, werdienen allereerst de begrippen arbeidsongeschiktheid, ziekteverzuim en verzuimparameters enige toelichting.

Bij uitkeringen krachtens de ziektewet en AAW/WAO is er in de wet sprake van arbeidsongeschiktheid. In de ziektewet is er sprake van arbeidsongeschiktheid voor de laatstelijk verrichte (eigen) arbeid, in de AAW/WAO voor in billikheid op te dragen arbeid.

In het algemeen spraakgebruik duidt men met arbeidsongeschikten veelal diegenen aan die een uitkering krachtens de $\mathrm{A}$ AW/WAO ontvangen; ontvangt men een uitkering krachtens de ziektewet, dan is sprake van zowel ziekteverzuim als arbeidsongeschiktheid (Buys, 1985). 
Met de inwoering van de ziektewet ontstond de behoefte tot het registreren van werzuim, allereerst ten behoeve van de uitwoering door de bedrijfsverenigingen, later ook ten behoeve van wetenschappelijk onderzoek naar de oorzaken en achtergronden van ziekteverzuim. Zo startte het Nederlands Instituut voor Praeventieve Gezondheidszorg (NIPG) na de tweede wereldoorlog met een registratiesysteem volgens afspraken van het International Labour Office (ILO) en de World Health Organisation (WHO) (Draaisma en Smulders, 1978). Gebruik makend van de NIPG ziekteverzuimcijfers begon het Centraal Bureau voor de Statistiek (CBS) met publikatie van ziekteverzuim gegevens. Sinds 1975 houdt ook de Stichting Coördinatie van Communicatie met betrekking tot Onderzoek inzake Ziekteverzuim (CCOZ) zich bezig met ziekteverzuimregistratie (Mertens en Streng, 1981). In 1987 is de CCOZ opgegaan in het Nederlands Instituut voor Arbeidsomstandigheden (NIA).

Als verzuimparameter wordt in de regel het begrip ziekteverzuimpercentage gebruikt: het gemiddeld aantal verzuimde dagen per honderd kalenderdagen (inclusief weekends, feestdagen) per persoon. Andere verzuimparameters (Smulders, 1984) zijn: de gemiddelde verzuim-/arbeidsongeschiktheidsduur (de gemiddelde duur per verzuimgeval) en de verzuimfrequentie (het gemiddeld aantal verzuimmeldingen per persoon per jaar).

\subsubsection{Statistische ontwikkelingen}

Het ziekteverzuim in Nederland stijgt in de periode 1950 tot 1980 (zie tabel 1.1); met name in de periode 1960 tot 1980 is er sprake van een relatief sterke stijging: 1,0 tot $1,4 \%$ per 5 jaar. Wordt deze stijging in de jaren 1950 tot 1975 vooral bepaald door de stijging van het ziekteverzuim bij de mannelijke werknemers, in de periode 1975 tot 1980 is er sprake van een explosieve stijging van het ziekteverzuim bij vrouwelijke werknemers. Na een stabilisatie in de jaren 1978 en 1979 treedt er in de tachtiger jaren een geleidelijke daling van op 10.0 tot $6.8 \%$; Deze daling slaat in 1989 om in een geleidelijke stijging van het ziekteverzuim, het eerst bij de vrouwelijke werknemers, waar de omslag zich voordoet in 1987, gevolgd door een stijging van het ziekteverzuim bij mannelijke werknemers vanaf 1989 . Deze stijging zet zich tot op heden voort.

\subsubsection{Verzuimbepalende factoren}

Al lange tijd wordt gestreefd naar een beheersing en beperking van zowel het kort-als langdurend ziekteverzuim. Hierbij spelen de als te hoog ervaren arbeids- en uitkeringskosten een belangrijke rol (Van den Heuvel, Sinnighe Damsté, Westerduin, 1990). Bij het ontstaan van ziekteverzuim spelen niet alleen ziekten en arbeidsomstandigheden maar ook andere maatschappelijke en sociale factoren een grote rol.

Het beïnvloeden van de maatschappelijke en sociale factoren kan een matigend effect hebben op het optreden van ziekteverzuim. Dit beïnloedbare deel van het ziekteverzuim wordt ook wel aangeduid als het zogenaamd vermijdbaar verzuim. De sociale wetgeving richtte zich op de loonderving. De Ongevallenwet (1901), die beschouwd kan worden als de eerste sociale verzekeringswet, is hiervan een voorbeeld (Geers, 
1988). Na de invoering van de Arbeidswet in 1889 werd in 1890 de Arbeidsinspectie in het leven geroepen. Het medisch element hierin ontbrak anvankelijk. Na de benoeming echter van een Medisch Adviseur in 1903 ontstond meer aandacht voor de omstandigheden, waaronder beroepsziekten optraden kennelijk met als doel op den duur tot een preventie van ziekten te komen. Door deze arbeidsgeneeskundige inbreng heeft de Arbeidsinspectie een positieve invloed gehad op de ontwikkeling van de bedrijfsgeneeskunde in Nederland (Burger, 1974).

Tabel 1.1 Ziekteverzuimpercentages in Nederland per 5 jaar en per jaar in de periode $1950 \mathrm{t} / \mathrm{m} 1989$; index: $1950=100$

\begin{tabular}{l|rr|rr|rr}
\hline jaren & mannen & index & vrouwen & index & total & index \\
\hline 1950 & 4.0 & 100 & 4.6 & 100 & 4.1 & 100 \\
1955 & 4.6 & 115 & 4.7 & 102 & 4.6 & 112 \\
1960 & 5.3 & 133 & 5.0 & 109 & 5.3 & 129 \\
1965 & 6.4 & 160 & 5.9 & 128 & 6.3 & 154 \\
1970 & 7.6 & 190 & 8.4 & 183 & 7.7 & 193 \\
1975 & 8.5 & 213 & 10.5 & 228 & 8.8 & 215 \\
1976 & 9.0 & 225 & 11.0 & 239 & 9.3 & 227 \\
1977 & 9.2 & 230 & 11.5 & 250 & 9.5 & 232 \\
1978 & 9.7 & 243 & 12.0 & 261 & 10.0 & 244 \\
1979 & 9.7 & 243 & 12.0 & 261 & 10.0 & 244 \\
1980 & 9.1 & 228 & 11.3 & 245 & 9.4 & 229 \\
1981 & 8.2 & 205 & 10.9 & 237 & 8.5 & 207 \\
1982 & 7.8 & 195 & 10.3 & 224 & 8.1 & 198 \\
1983 & 7.2 & 180 & 9.4 & 204 & 7.5 & 183 \\
1984 & 6.9 & 173 & 9.2 & 200 & 7.2 & 176 \\
1985 & 6.6 & 165 & 8.6 & 187 & 6.9 & 168 \\
1986 & 6.6 & 165 & 8.4 & 183 & 6.9 & 168 \\
1987 & 6.3 & 158 & 8.7 & 189 & 6.7 & 163 \\
1988 & 6.2 & 155 & 8.7 & 189 & 6.6 & 161 \\
1989 & 6.4 & 160 & 8.8 & 191 & 6.8 & 166 \\
\hline
\end{tabular}

Bron: NPPG, 1990.

Onder invloed van het stijgende ziekteverzuim en het toenemend aantal arbeidsongeschikten ontstaat ook binnen de uitvoeringsorganisaties sociale verzekeringen toenemend aandacht voor preventie van ziekteverzuim. Een voorbeeld hiervan is het Actieprogramma Ziekteverzuim 1972 - 1975, dat in opdracht van de Commissie Opvoering Produktiviteit/SER door het Nederlands Instituut voor Praeventieve Gezondheidszorg TNO (NIPG/TNO) werd uitgevoerd (Draaisma en Smulders, 1978). Ook de oprichting wan de Stichting Coördinatie van Communicatie met betrekking tot Onderzoek inzake Ziekteverzuim (CCOZ) in 1976 op gezamenlijk initiatief van de ministeries van Sociale Zaken en Binnenlandse Zaken, de Sociale Verzekeringsraad ( $S V r$ ) en de Federatie van Bedrijfsverenigingen (FBV) wijst op een streven naar beheersing van het verzuim. Het 
advies van de Sociaal Economische Raad (1982) onderstreept de functies, die de bedrijfswerenigingen, onder andere belast met de uitvoering van de ziektewet, bij de beperking wan het ziekteverzuim hebben:

a. verbetering van de verzuimregistraties, onder andere door een uitbreiding met diagnosegegevens, het analyseren van deze verzuimgegevens en het op grond hierwan signaleren van risicogroepen aan bedrijven en bedrijfstakken;

b. het adviseren van bedrijven over het nemen van maatregelen.

Dit advies heeft er mede toe bijgedragen dat bedrijfsverenigingen registratiesystemen hebben ontwikkeld om meer inzicht te krijgen in het ziekteverzuim. Voorbeelden hiervan zijn het Ziekterisico Registratiesysteem (ZIRIS) het - van meer recente datum het Informatiesysteem Medische Functie van het GAK. Deze informatiesystemen leveren verzuminformatie over (delen van) de werknemers- en bedrijfspopulatie. Volgens de verzuimgegevens van het Gemeenschappelijk Administratiekantoor heeft ruim 40\% van de verzuimers binnen éen week het werk weer hervat; na twee resp. vier weken heeft 80 resp. $89 \%$ het werk hervat. Van het totaal aantal ziektegevallen duurt $8,3 \%$ langer dan 6 weken; hiermede is $62 \%$ van het aantal ziektedagen gemoeid.

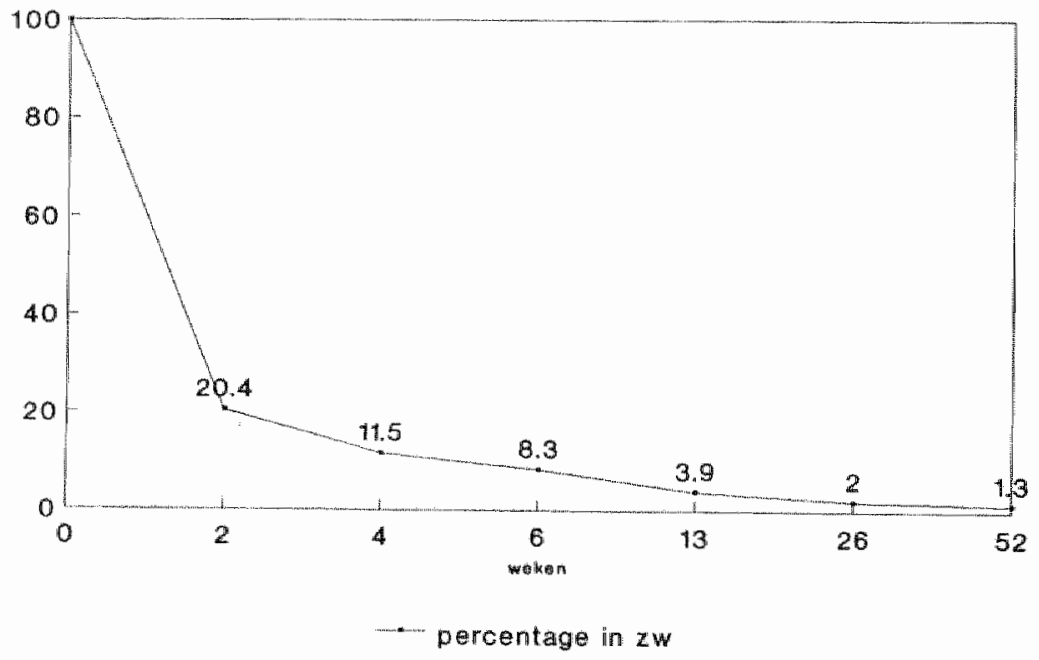

OAK, 190

Figurr 1 Uitstroomcurve GAK-bedrijfsverenigingen

Tenslotte heeft $5 \%$ van het aantal ziektegevallen een verzuimduur van meer dan 13 weken (zie figuur 1). Hiermede is $45 \%$ van het aantal verzuimdagen gemoeid (zie 
figuur 2). Uiteindelijk komt $1,5 \%$ in de WAO terecht (SVR, 1988; GAK, 1990). Van degenen die na 13 resp. 26 weken nog arbeidsongeschikt zijn bereikt éénderde resp. tweederde de WAO (GAK, 1985, 1990).

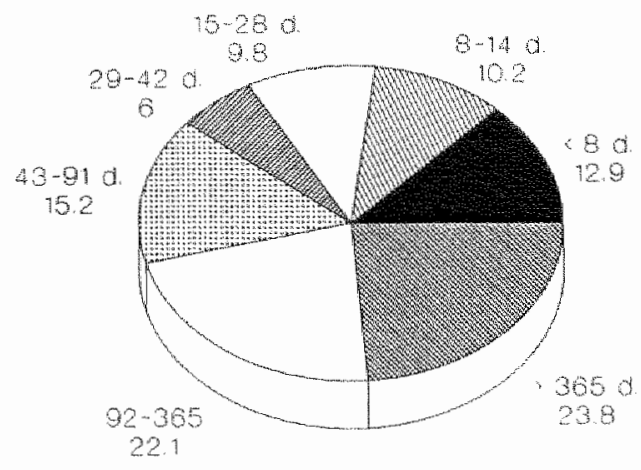

Figuur 2 Verzuim-wolume 1989 GAK-bedrijfsverenigingen in $\%$

Het beroep op de WAO is zeer groot. Bij de invoering van de WAO in 1967 verwachtte men na een jaar of zeven een stabilisatie rond de 150.000 uitkeringsgerechtigden. In werkelijkheid groeide het aantal uitkeringsgerechtigden tot 164.000 in 1968 en 349.00 in 1975 . In 1975 werd de AAW van kracht; hierdoor steeg het aantal witkeringsgerechtigden tot 475.000 in 1976 . In 1983 werd een aantal uitkeringsgerechtigden van 690.000 bereikt. In 1988 bedroeg het aantal uitkeringsgerechtigden 755.768 (zie tabel 1.2).

Tabel 1.2 In- en uitstroom AAW/WAO in aantallen uitkeringsgerechtigden in de periode 1980 tot en met 1988

\begin{tabular}{cccc}
\hline & aantal nieuwe gevallen & aantal beëindigde gevallen & totalal aantal gevallen \\
\hline 1981 & 68.946 & 53.465 & 660.108 \\
1982 & 67.234 & 53.044 & 674.298 \\
1983 & 66.980 & 51.252 & 690.026 \\
1984 & 65.359 & 50.641 & 704.744 \\
1985 & 65.278 & 59.059 & 710.963 \\
1986 & 64.643 & 55.280 & 725.991 \\
1987 & 71.426 & 55.649 & 735.266 \\
1988 & 76.100 & 55.306 & 755.768 \\
\hline
\end{tabular}

Bron: GMD, Statistische informatie 1985 en 1989.

Hierbij moet men zich realiseren dat deze toename het netto-resultaat is van het aantal nieuwe gerechtigden verminderd met het aantal beëindigingen. Beëindiging geschiedt bij het bereiken van de 65 -jarige leeftijd, het weer arbeidsgeschikt worden of overlij- 
den. De afname van de groei van het aantal uitkeringsgerechtigden wordt voornamelijk veroorzaakt door beèindiging wegens het bereiken van de 65-jarige leeftijd.

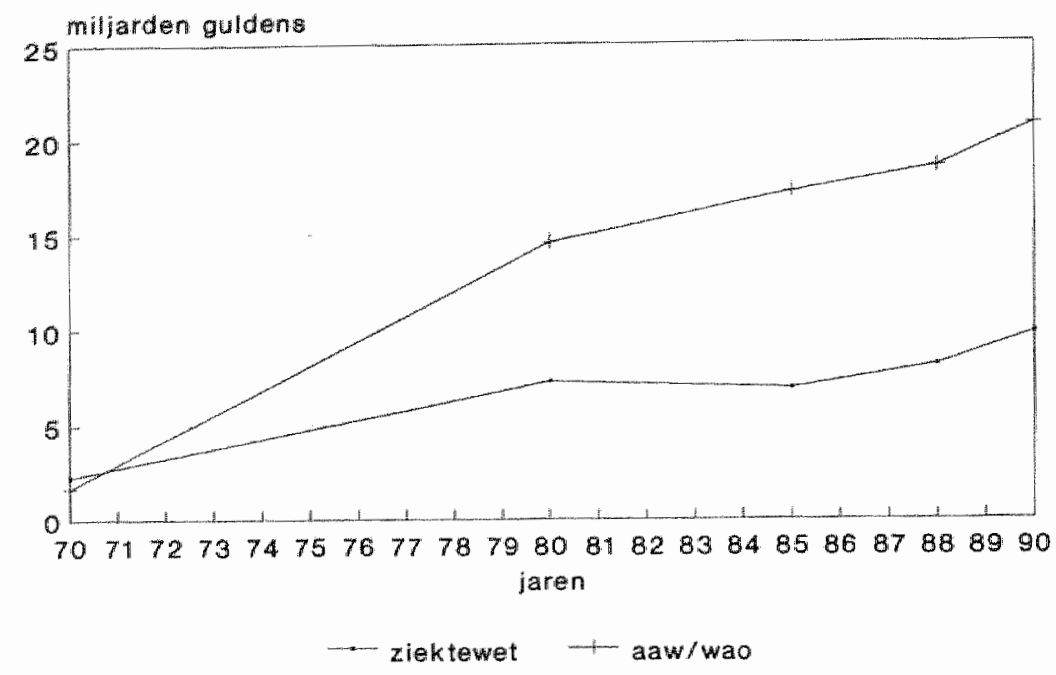

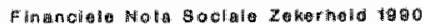

Fuguur 3 Lastenontwikkeling $Z W$ en AAW/WAO van $1970 \mathrm{t} / \mathrm{m} 1990$ in miljarden guldens

De ontwikkeling van de financiële lasten toont sedert 1960 eenzelfde stijgende lijn. Werd in 1960 een bedrag van 3 miljard gulden aan uitkeringen verstrekt (Doeleman, 1980), in 1990 zijn de lasten van de arbeidsongeschiktheidswetten ZW, AAW en WA$O$, inclusief de kosten van de administratie en het beheer ten behoeve van deze wetten gestegen tot ruim 30 miljard gulden (zie figuur 3). De ZW, AAW en WAO tezamen vormen thans $\pm 25 \%$ van de kosten van de sociale zekerheid en leggen beslag op \pm $7 \%$ van het nationaal inkomen.

In de jaren 1986-1987 zijn maatregelen getroffen die tot doel hadden het aantal uitkeringsgerechtigden te verminderen. Tot deze maatregelen behoren de verlaging van het uitkeringsniveau en het wegvallen van de verdiscontering werkloosheid. Deze maatregelen hebben, zoals tabel 1.2 laat zien, na 1987 niet geleid tot een daling van het aantal WAO-arbeidsongeschikten.

Het meest zorgelijke blijft het grote aantal "nieuwe" gevallen: het aantal nieuwe toekenningen in het betreffende jaar. Daarnaast hebben ook de herbeoordelingsoperaties, die tot doel hebben het aantal lopende WAO-toekenningen te verminderen, slechts een zeer beperkt en, zoals figuur 4 laat zien, tijdelijk effect. 


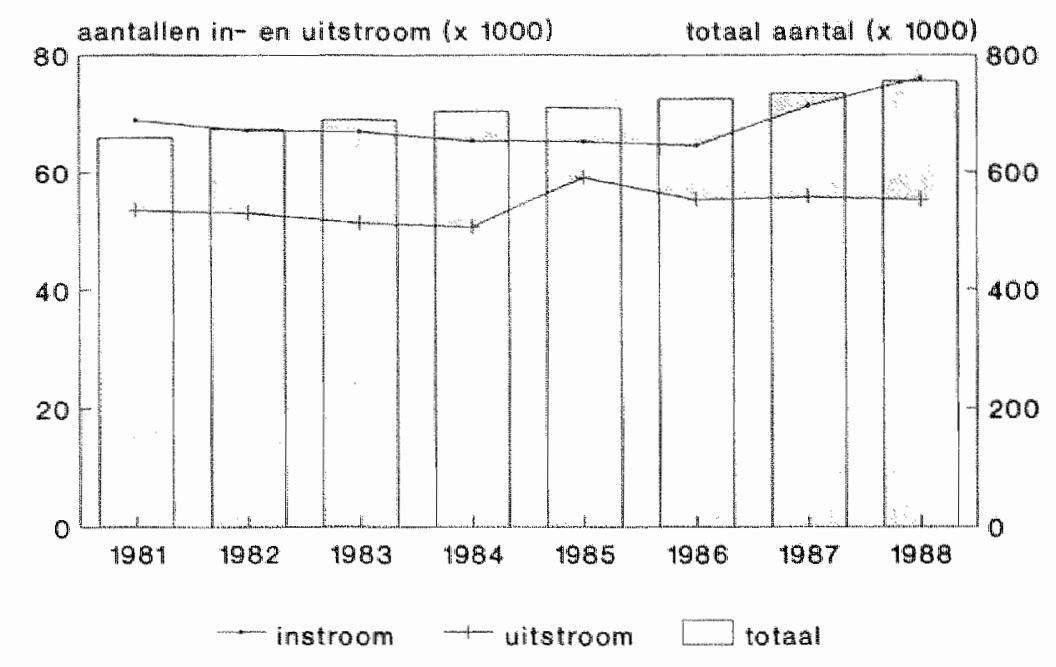

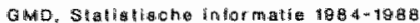

Figuur 4 In- en uitstroom WAO en totaal aantal uitkeringsggerechtigden $1981 \mathrm{t} / \mathrm{m} 1988$

\subsubsection{De maatschappelijke context}

Het hoge aantal arbeidsongeschikten, zowel kortdurend als langdurend, mag als onwenselijk worden beschouwd vanuit medisch en maatschappelijke oogpunt.

Uit medisch oogpunt is het zonder meer verontrustend dat veel werknemers zodanig ziek zijn, dat er sprake is van ziekteverzuim en arbeidsongeschiktheid. Vroege (1982, 1983) wijdt dit aan een toename van de produktiviteit, die leidt tot een vergroting van de belasting en stress in de werkende bevolking. Deze belastingstoename wordt niet gecompenseerd door een adlequate toename van het aantal vrije dagen. Voor de totale Nederlandse bevolking geldt dat het sterftecijfer en de levensverwachting gunstiger zijn dan in de ons omringende landen. De intrede in de WAO is met name verontrustend voor de werknemers van jonge en middelbare leeftijd. Bij deze leeftijdsgroepen vormen de diagnosegroepen: psychische ziekten en ziekten van het bewegingsstelsel, een belangrijke oorzaak. In vergelijking evenwel met België en West-Duitsland hebben deze werknemers een relatief gunstige gezondheidstoestand; bij hen komen relatief meer non-letale klachten en aandoeningen yoor (Prins, 1990). Hoewel de totale Nederlandse populatie gunstig afsteekt wat betreft het artsenbezoek en medicijngebruik, die lager liggen dan in de ons omringende landen, leidt het grote aantal arbeidsongeschikten desalniettemin tot een grote druk op de curatieve sector met kans op medicalisering.

De maatschappelijke verontrusting over het hoge aantall langdurig arbeidsongeschikten is groot. Overheid en politici streven naar een vermindering en beheersing van het 
aantal langdurig arbeidsongeschikten. Maatregelen als het wegvallen van de verdiscontering van de werkloosheid in de WAO (het laten meewegen van de werkloosheid bij de vaststelling van het arbeidsongeschiktheidspercentage) en verlaging van de uitkeringspercentages kunnen als een uiting van dit streven gezien worden. Tot op heden hebben deze maatregelen niet de gewenste vermindering van het aantal langdurig arbeidsongeschikten tot stand heeft gebracht.

Langdurige arbeidsongeschiktheid gaat veelal gepaard met negatieve veranderingen. Vervreemding van de werkplek, het missen van de regelmaat van werk en de contacten en meningsvorming op de werkplek en het gevoel geen bijdrage te leveren aan de malatschappij (Merens-Riedstra, 1981). Van der Horst (1988) constateert een relatie tussen langdurige arbeidsongeschiktheid en een verslechterende gezondheidstoestand. Hoe langer men afwezig is op het werk, hoe geringer de bereidheid is bij werkgever om een werknemer weer te laten hervatten. De inkomenspositie van de arbeidsongeschikte werknemer verslechtert.

\subsubsection{De invloed van de curatieve gezondheidszorg op arbeidsongeschiktheid}

De curatieve gezondheidszorg toont betrekkelijk weinig interesse in het ziekteverzuim. De arbeid van de patiënt wordt met name door huisartsen vaak als oorzaak van ziekte wordt aangeduid. De huisarts richt zich op de individuele patiënt en neemt het aspect arbeid niet of nauwelijks mee in zijn therapeutische overwegingen.

Wat er na de ziekmelding gebeurt, hangt onder andere af van de opleiding, attitude, ervaring, werkomstandigheden en samenwerkingsrelaties van de huisarts (Buys, 1985). Binnen de eerste lijn valt dit bij een goede samenwerking nog wel mee (bijvoorbeeld bij fysiotherapie); een verwijzing naar een specialist echter leidt tot wachttijden voor onderzoek en behandeling. Ook in de fase, die voorafgaat aan het ziekteverzuim - de pre-verzuimfase - kan de curatieve arts door een goede samenwerking met de ba een bijdrage aan de preventie van ziekteverzuim leveren (Buys, 1985). Hetzelfde geldt mijns inziens voor de samenwerking tussen huisarts en $\mathrm{vg}$.

Deze samenwerking is noodzakelijk, temeer daar onder de miljoenen patiënten, die zich jaarlijks onder behandeling stellen, er zeer velen zijn die tevens een uitkering krachtens de sociale verzekeringswetten ontwangen. Voor het ontbreken van communicatie tussen huisartsen en $\mathrm{vg}^{\prime} \mathrm{n}$ wordt de in Nederland geldende scheiding tussen behandeling en controle als excuus gebruikt.

Vaak wordt de invloed van het oordeel en de handelwijze van de curatieve arts over de werkhervatting onderschat. Daarnaast wordt onvoldoende onderkend wat de invloed van wachttijden is op de duur van de arbeidsongeschiktheid en de reintegratiemogelijkheden. De Groot (1958) sprak in ons land als eerste over het zogenaamde iatrogene verzuim, doelend op het grote aantal verwijzingen naar een specialisme en de wachttijden. Het gevolg hiervan is dat de curatieve gezondheidszorg, naast de arbeidsinhoud, arbeidsorganisatie en de sociale zekerheid, als een der oorzaken van het ziekteverzuim wordt genoemd. 
Maatschappelijk is de relatie tussen arbeid en gezondheid een probleem. De relatie tussen werk en ziekte wordt omgeven door een groot aantal wetten ter voorkoming van de nadelige effecten wan inkomensderving ten gevolge van arbeidsongeschiktheid, ouderdom, werkloosheid etc. Daamaast bestaan wetten gericht op het voorkomen van ongunstige arbeidsomstandigheden en bevordering van de herinpassing in het arbeidsproces van gehandicapte werknemers. Deze studie beperkt zich tot onderzoek naar de uitvoering van slechts een beperkt aantal sociale verzekeringswetten: de arbeidsongeschiktheidswetten, welke van toepassing zijn gedurende het eerste arbeidsongeschiktheidsjaar. Ter completering van deze studie is in bijlage 1 een overzicht opgenomen van de thans geldende sociale verzekeringswetten in Nederland.

\subsection{De uitvoeringsorganisaties}

In de voorgaande paragrafen is de omvang van het gebruik van arbeidsongeschiktheidsverzekeringen ais probleemweld beschreven. Dit onderzoek richt zich op de uitvoering van de arbeidsongeschiktheidsverzekeringen voor werknemers in de private sector en ambtenaren gedurende thet eerste jaar arbeidsongeschiktheid. Centraal staan de aard en effecten van het verzekeringsgeneeskundig handelen en wel in hun relatie tot de verzuimduur. Alvorens in te gaan op het verzekeringsgeneeskundig handelen worden allereerst de uitvoeringsorganisaties en de wijze van uitvoering beschreven.

Werkgevers en werknemers zijn gezamenlijk verantwoordelijk voor een goede uitvoering van de arbeidsongeschiktheidswetten. De werkgever heeft met betrekking tot de uitvoering van de ziektewet een registratiefunctie. Als een werknemer arbeidsongeschikt wordt, informeert de werkgever zo snel mogelijk de bedrijfsvereniging over de ingangsdatum van de arbeidsongeschiktheid, het loon en het arbeidsverleden van de werknemer. Deze gegevens zijn noodzakelijk ter vaststelling van het recht op, de ingangsdatum en de hoogte van de uitkering.

De uitvoering van de arbeidsongeschiktheidswetten geschiedt door eén van de 19 bedrijfsverenigingen (BV'en). Elke onderneming is van rechtswege aangesloten bij een bedrijfsvereniging. Bij de uitvoering wan de WAO en AAW zijn de Bedrijfsvereniging verplicht advies te vragen aan de Gemeenschappelijk Medische Dienst.

De uirwoering van de arbeidsongeschiktheidsregelingen woor ambtenaren is opgedragen aan zowel de werkgever als het Algemeen Burgerlijk Pensioenfonds.

In paragraaf 1.3.1 worden de uitvoeringsorganisaties ten behoeve van werknemers beschreven. Paragraaf 1.3 .2 bevat een beschrijving van de uitvoeringsorganisatie ten behoeve van ambtenaren.

\subsubsection{Uitvoeringsorganisaties sociale verzekeringen}

Bij de uitvoering van de sociale verzekeringswetten zijn organen uit het bedrijfsleven betrokken: de zogenaamde Bedrijfsverenigingen.

De Bedrijfsverenigingen zijn opgericht door eén of meer organisaties van werkgevers, 
welke naar het oordeel van de minister wan Sociale Zaken en Werkgelegenheid (SoZaWe) representatief zijn voor een bedriffstak, en één of meer organisaties van werknemers. De Organisatiewet Sociale Verzekering bepaalt aan welke eisen Bedrijfsverenigingen dienen te voldoen. $\mathrm{Zij}$ moeten de uitvoering van de sociale verzekering voor een bepaalde tak vam het bedrijfs- of beroepsleven tot doel hebben; zij mogen geen winst maken; het bestuur moet uit evenveel werkgevers als werknemersvertegenwoordigers uit de bedrijfstak zijn samengesteld; en zij moeten erkend zijn door de Minister. Voor elke tak van het bedrijfs- en beroepsleven kan slechts één Bedrijfsvereniging worden erkend. De Organisatiewet Sociale Verzekering heeft het gehele bedrijfs- en beroepsleven verdeeld in 19 onderdelen (aanvankelijk 26). Elke tak van het bedrijfs- en beroepsleven valt onder één der 19 onderdelen. Voor elk der 19 takken van het bedriifs- en beroepsleven is de uitwoering van de sociale verzekering opgedragen aan een aparte Bedrijfsvereniging (bijlage 2). Om een forum voor onderling overleg te scheppen en gemeenschappelijke belangen te kunnen behartigen werd een overkoepelend orgaan in het leven geroepen: de Vereniging "De Federatie van Bedrijfsverenigingen" (FBV). De FBV geeft aan de Bedrijfsverenigingem niet-bindende adviezen over het uitvoeringsbeleid van de sociale verzekering.

Nu er eenmaal voor gekozen was de uitwoering wan de sociale verzekeringswetten op te dragen atan Bedrijfsverenigingen, zou ook een gerneenschappelijke administratie door een door het bedrijfsleven opgericht en geleid administratiekantoor uitgevoerd moeten worden. Van overheidswege werd voorgesteld over te gaan tot de oprichting van een centraal administratiekantoor, opgericht door en onder leiding van de Sociale Verzekeringstaad. In principe zouden alle Bedriffsverenigingen hun administratie moeten opdragen aan dit centrale administratiekantoor, tenzij klemmende argumenten reden waren voor dispensatie.

Er bestond echter verzet tegen deze als vrijheidsbeknotting ervaren centrale administratie. Ook het feit dat dit centrale administratiekantoor opgericht en geleid zou worden door de Sociale Verzekeringsraad, die geen zelfstandig orgaan van het bedrijfsleven was, leidden tot grote bezwaren. Men heeft tenslotte gekozen voor een gemeenschappelijk administratiekantoor, waarbij Bedrijfsverenigingen zich vrijwillig kunnen aansluiten en dat beheerd wordt door de centrale organisaties van werknemers en werkgevers: het Gemeenschappelijk Administratiekantoor (GAK). Bedrijfsverenigingen, die zelfstandig hun taken uitvoeren, worden zelf-administrerende Bedrijfswerenigingen genoemd (ZA-BV). Thans voert het GAK de administratie voor een 13-tal Bedrijfsverenigingen (zie bijlage 2). Bedrijfswerenigingen en de Vereniging "Het Gemeenschappelijk Administratiekantoor" voeren de administratie ten behoeve van de uitvoering van een vijftal sociale verzekeringswetten: de ziektewet $(\mathrm{ZW})$, de wet op de arbeidsongeschiktheidsverzekering (WAO), de algemene arbeidsongeschiktheidswet (AAW), de werkloosheidswet (WW) en de Toeslagenwet (TW). Een en ander is vastgelegd in de Organisaticwet Sociale Verzekeringen. De ZW, WAO en WW zijn werknemers verzekeringen; zij gelden voor werknemers. Een werknemer in de zin van de wet is de natuurlijke persoon, jonger dan 65 jaar, die in een privaatrechtelijke (bij een particulier persoon of onderneming) of publiekrechtelijke (bij Staat, Provincie, Water- 
schap) dienstbetrekking staat. We spreken van een dienstbetrekking, als een 3 voorwaarden is voldaan: de werknemer verricht persoonlijke arbeid, de werkgever betaalt de werknemer loon en tussen werkgever en werknemer bestaat een gezagswerhouding. Uitgezonderd van de verzekering zijn ABP-gerechtigden (ambtenaren) en dienstplichtige militairen.

De AAW is een volksverzekering met het karakter van een werknemersverzekering: het voorzien in een uitkering indien door ziekte of gebrek geen arbeid verricht kan worden. Deze wet geldt voor alle ingezetenen ongeacht hun nationaliteit, die de leeftijd van 65 nog niet bereikt hebben. Naast criteria als wachttijd (52 weken) en mate van arbeidsongeschiktheid (minimaal 25\%) moet men in het jaar woorafgaande aan het intreden van de arbeidsongeschiktheid inkomen hebben verworven. In deze zin is de $A A W$, zoals de werknemerswerzekeringen $Z W$ en $W A O$, cen loondervingsverzekering. Dit loondervingsaspect alsmede het feit dat deze wet ook van toepassing is op werknemers, naast ambtenaren en zelfstandigen, heeft ertoe geleid "dat de uitvoering is opgedragen aan de Bedrijfsverenigingen.

Andere sociale verzekeringswetten mogen alleen na uitdrukkelijke toestemming van de minister van Sociale Zaken geadministreerd worden. Op grond hiervan voert het GAK de administratie van een aantal bedrijfspensioenfondsen en van de Gemeenschappelijk Medische Dienst (GMD).

Onder administratie wordt onder andere verstaan: premie-inning, verstrekken van uitkeringen, het verrichten van medische beoordelingen, het voeren van een financiële administratie en het statistisch bewerken van gegevens.

Het Gemeenschappelijk Administratiekantoor en de BV'en zijn erkend door de minister van Sociale Zaken en onderworpen aan het toezicht van de Sociale Verzekeringsraad (SVR). De SVR kan zich laten vertegenwoordigen op vergaderingen van het bestuur van het GAK en $B V$ en voorschriften geven ten aanzien van de inrichting van de administratie.

\subsubsection{De uitvoering van de ziektewet}

De doelstelling van de Bedrijfsverenigingen bij de uitvoering van de ziektewet kan alss volgt onschreven worden: het verstrekken van een uitkering krachtens de ziektewet aan diegenen, die daarop krachtens de ziektewet aanspraak kunnen maken.

Deze doelstelling impliceert ook het niet-toekennen van een uitkering aan diegenen, die daarop geen recht hebben. Er zal dus sprake moeten zijn van toegangsbewaking, of populair gezegd: controle. De Bedrijfsverenigingen hebben derhalve als aanvullende doelstelling:

- het voorkomen van ongerechtvaardigd verzuim;

- het voorkomen van vermijdbaar verzuim.

In de doelstelling "het voorkomen van onterecht verzuim", komt het controle-aspect naar woren: allereerst dient te worden vastgesteld of een werknemer ongeschikt voor 
zijn/haar arbeid wegens ziekte of gebrek. De doelstelling "het voorkomen van vermijdbaar verzuim" wijst op alle activiteiten, die ontplooid kunnen worden ter verkorting van de arbeidsongeschiktheidsduur, ter beyordering van de reintegratie in het arbeidsproces, alsmede op het treffen van preventieve maatregelen ter voorkoming van verzuim.

De uitwoering van de ziektewet ligt in handen van de BV, het GAK of het bedrijf. Of en in welke mate een bedrijf de ziektewet uitvoert en is afhankelijk van de verzekeringsvorm. De verzekeringsvorm bepalt of het bedrijf het eigen risico draagt en de uitwoering van de ziektewet, al of niet met de medische beoordeling zelf, overigens onder supervisie van de BV, uitvoert.

Wij kennen 3 verzekeringsvormen met betrekking tot de ziektewet, die te onderscheiden zijn naar de wijze van premiebetaling, premiebeheer en het verstrekken van een uitkering of loondoorbetaling:

a. omslaglid: de leden dragen het ziekterisico gezamenlijk. De ziekiewetpremie is gebaseerd op het ziekterisico van alle bedrijven in dezelfde Bedrijfsvereniging en wordt afgedragen aan de betreffende Bedrijfswerenigingen, die de inning ervan en de uitkeringsverstrekking verzorgen. Een bedrijf met een hoog ziekteverzuim betaalt derhalve evenveel premie als een bedrijf met een lag ziekteverzuim.

b. afdelingskas. Hierbij zijn een of enkele aan elkaar verwante bedrijven aangesloten. Deze bedrijven storten de premie in een eigen kas en verstrekken daaruit de uitkeringen onder supervisie van de Bedrijfswereniging. De ziektewetpremie is gebaseerd op het ziekterisico van de leden van de afdelingskas. Hoe lager het ziekte verzuim, hoe lager de premie.

c. eigen-risicodrager. Deze bedrijven innen geen premie en verstrekken geen uitkering; Bij deze vorm is de werkgever verplicht bij ziekte het loon door te betalen. Ook hier voert de Bedrijfsvereniging supervisie uit.

Bij afdelingskas en eigen-risicodragers (de zogenaamde "akers") bestaat er een directe relatie tussen de op te brengen premie of ziekengeld en de hoogte van het ziekteverzuim bij de aangesloten leden. Deze verzekeringsvormen zijn uit kostenoogpunt gunstig voor bedrijven met een laag ziekteverzuim. Tevens vormt deze verzekeringsvorm een prikkel om het verzuim te verminderen en zo laag mogelijk te houden. Bedrijven met een hoog ziekteverzuim zullen wit financiële overwegingen veelal kiezen voor de status van omslaglid.

Afhankelijk van de mate, waarin bedrijven zelf de verantwoordelijkheid dragen voor de uitvoering van de ziektewet, bestaan er 3 controlevormen wat betreft de verzekeringsgeneeskundige controle en begeleiding:

1. controle en begeleiding door het Gemeenschappelijk Administratiekantoor of de Bedrijfsvereniging; Dit geldt voor de onslagleden en de zogenaamde "gele" akers ("geel" slaat hierbij op de kleur van de gebruikte formulieren); 
2. controle en begeleiding door het bedrijf zelf; in het BV-jargon spreekt men van "superaker"; de Bedrijfsvereniging of het GAK oefent de supervisie wit op de verzekeringsgeneeskundige controle en begeleiding. Tot slot bestat er

3. een combinatie van 1 en 2 , waarbij de controle en begeleiding in het kader van de uitvoering van de ziektewet wordt uitgevoerd gedurende de eerste 10 weken door het bedrijf zelf en nà de $10 \mathrm{e}$ week door het GAK of de Bedrijfswereniging. In het BV-jargon spreekt men naar de kleur van de gebruikte formulieren van een "rode aker".

Achtereenvolgens worden de door het Gemeenschappelijk Administratiekantoor en de zelfstandige Bedrijfsverenigingen gehanteerde controlevormen beschreven.

\section{a. Gemeenschappelijk Administratiekantoor (GAK)}

Binnen het Gemeenschappelijk Administratiekantoor komen de drie bovenbeschreven controlevormen van de controle en begeleiding voor.

De meest voorkomende vorm is controlevorm 1, waarbij de controle en begeleiding tijdens de ziektewet wordt uitgevoerd door eigen $\mathrm{vg}^{\prime} \mathrm{n}$. Deze $\mathrm{vg}$ ' $\mathrm{n}$, die in dienst zijn van het GAK dragen zorg voor de controle en begeleiding van werknemers van bedrijw ven, aangesloten bij Bedrijfsverenigingen, waarvoor het GAK de administratie voert. ledere $\mathrm{vg}$ draagt zorg voor de werknemers, woonachtig in een bepaald geografisch gebied (niet per definitie het vestigingsgebied van het bedrijf van de werknemers).

De laatste jaren is er in toenemende mate sprake van bedrijfsgebonden vg'n, die alle werknemers van een bedrijf, ongeacht hun woonplaats, controleren en begeleiden. Hiermede wordt de afstand tussen vg en bedrijf verkleind, waarvan een verzuimdalend en preventief effect wordt verwacht.

De verzekeringsgeneeskundige controle en begeleiding in het kader van de ziektewet kan in bepaalde omstandigheden opgedragen zijn aan een bedrijf: de zogenaamde "superaker" (controlevorm 2). De controle en begeleiding gedurende de ziektewet wordt uitgevoerd door een $\mathrm{vg}$ of $\mathrm{ba} / \mathrm{vg}$ in dienst van het bedrijf onder supervisie van het Gemeenschappelijk Administratiekantoor.

Bij controlevorm 3 is de controle en begeleiding gedurende de eerste 10 weken arbeidsongeschiktheid opgedragen aan het bedrijf: de zogenaamde "rode aker". Deze controle en begeleiding wordt uitgevoerd door de ba dan wel een andere door het bedrijf gecontracteerde arts (bijvoorbeeld een huisarts). Ook hier vervult het Gemeenschappelijk Administratiekantoor een superviserende rol. De superaker (controlevorm 2) en de rode aker (controlevorm 3) laten de beoordeling en begeleiding tijdens de ziektewet uitvoeren door eigen vg'n (onder andere Philips) of artsen, die zowel een bedrijfsgeneeskundige alsook een verzekeringsgeneeskundige tak hebben: de ba/vg'n (onder andere DSM). 


\section{b. Zelfatministrerende Bedrifsverenigingen (ZA)}

De controlevormen bij de zelfadministrerende Bedrijfswerenigingen worden onder andere bepaald door het aantal aangesloten verzekerden. Hoe kleiner de Bedrijfsvereniging, hoe meer gebruik gemaakt zal worden van contractartsen bijvoorbeeld huisartsen (niet-vg'n).

De Bedrijfsvereniging voor de Bouwnijverheid (BV Bouw, Sociaal Fonds Bouwnijverheid, SFB) maakt, evenals het Gemeenschappelijk Administratiekantoor gebruik van $v g^{\prime} n$ in eigen dienst.

De Bedrijfsvereniging voor de Gezondheid, Geestelijke en Maatschappelijke Belangen (BVG) laat tot de tweede thelft van de tachtiger jaren de controle en begeleiding gedurende de eerste 3 maanden uitvoeren door huisartsen. De Bedrijfsvereniging voor de Detailhandel, Ambachten en Huisvrouwen maakte tot 1987 uitsluitend gebruik van huisartsen. Momenteel wordt door deze bedrijfsverenigingen gedurende het gehele ziektewettraject in toenemende mate gebruik gemaakt wan eigen vg'n.

De Bedrijfsvereniging voor de Tabakverwerkende Industrieën, de Bedrijfsvereniging voor het Bakkersbedrijf en de Bedrijfsvereniging voor het Slagers- en Vleeswarenbedrijf, de Groothandel in Vlees en de Pluimveeslachterijen "De Samenwerking" en de Bedrijfswereniging voor het Agragrisch Bedrijf maken bij de controle en begeleiding gebruik van huisartsen.

\subsubsection{Uitvoeringsorganisatie ten behoeve van ambtenaren}

De uitvoering van de arbeidsongeschiktheidsregelingen voor ambtenaren is op grond van de ambtenarenwet en de verschillende rechtspositionele reglementen in handen gelegd van de werkgever.

In geval van tijdelijke arbeidsongeschiktheid is de werkgever belast met en verantwoordelijk voor de beoordeling en begeleiding van arbeidsongeschikte werknemers. De werkgever makt thiertoe gebruik van een door de minister erkende medische dienst (de Rijksbedrijfsgezondheids- en Biedrijfsveiligheidsdienst, een gemeentelijke of districtsgezondheidsdienst) of een hiertoe gecontracteerde arts. Bovengenoende diensten ontlenen hun taken aan de ambtenarenwet en de rechtspositionele reglementen (zoals onder andere het Algemeen Rijksambtenarenreglement ARAR); de taken op grond van de ambtenarenwet en de verschillende reglementen zijn in hoge mate uniform.

Als de arbeidsongeschiktheid 8 maanden heeft geduurd, dient de werkgever een advies $\mathrm{ABP}$ te vragen in verband met de vaststelling van het recht op en de hoogte van een witkering krachtens de AAW. De werkgever kan los hiervan de begeleiding van de werknemers voortzetten.

Wanneer er sprake is of lijkt van een blijvende arbeidsongeschiktheid kan de werkgever of werknemer advies vragen aan het ABP; de cerste acht maanden arbeidsongeschiktheid zijn zij hiertoe niet verplicht. Het ABP-bestuur neemt op grond van het verzekeringsgeneeskundig en arbeidsdeskundig advies van de Bedrijfseenheid Arbeidsongeschiktheidsverzekering, afdeling Medische Dienst (voorheen Sociaal Medische Sector) de uiteindelijke beslissing. Deze beslissing kan zijn een volledige afkeuring of 
cen herplaatsbaarheidsverklaring.

Ten aanzien van de herplaatsbaarheid wordt onderscheid gemaakt tussen herplaatsbaarheid binnen of buiten het eigen bedrijf.

Wordt een werknemer herplaatsbaar geacht birnen het eigen bedrijf, dan wordt de werkgever geacht de herplaatsing te realiseren. Hierbij zal hij gebruik maken van de adviezen en de hulp van de ba/vg. Eventueel loonverlies (het verschil tussen wat men heeft verdiend en nog kan verdienen) wordt (deels) gecompenseerd met een herplatsingstoelage, waaraan het loonverlies uitgedrukt in procenten ten grondslag ligt.

Indien een werknemer well herplaatsbaar is doch niet binnen het eigen bedrif kan de werknemer ontslagen worden, waarna een herplaatsingswachtgeld wordt toegekend; na 5 jaar zal dit omgezet worden in een invaliditeitspensioen. Indien de werknemer niet ontslagen wordt (nogmaals, dit is een zaak van de werkgever!), kan hij, in geval van volledige afkeuring, tot het 65 e jaar rekenen op $80 \%$ van het laatst genoten salaris.

Het zal duidelijk zijn, dat hoewel er geen wettelijke verplichting bestaat tot het melden aan het $\mathrm{ABP}$ en het realiseren van geadviseerde herplaatsingen, financiële overwegingen een melding aan het $\mathrm{ABP}$ en het meewerken aan herplaatsingen woor de werkgever aantrekkelijk maken.

\subsubsection{Naamgeving artsen}

Uit het voorgaande is duidelijk geworden dat binnen de uitvoeringsorganisaties voor werknemers in de private en overheidssector verschillende categorieën artsen c.q. sociaal geneeskundigen werkzaam zijn: $\mathrm{vg}^{\prime \prime} \mathrm{n}$ en ba/vg'n.

Binnen ến uitvoeringsorganisatie kunnen de zowel $\mathrm{vg}^{\prime} \mathrm{n}$ als ba/vg'n voorkomen (zie figuur 5). Hoewel de GMD en het ABP niet in het onderzoek zijn betrokken, zijn zij volledigheidshalve wel in het schema opgenomen. De verklaring van de afkortingen is opgenomen in de afkortingenlijst op pag. 181.

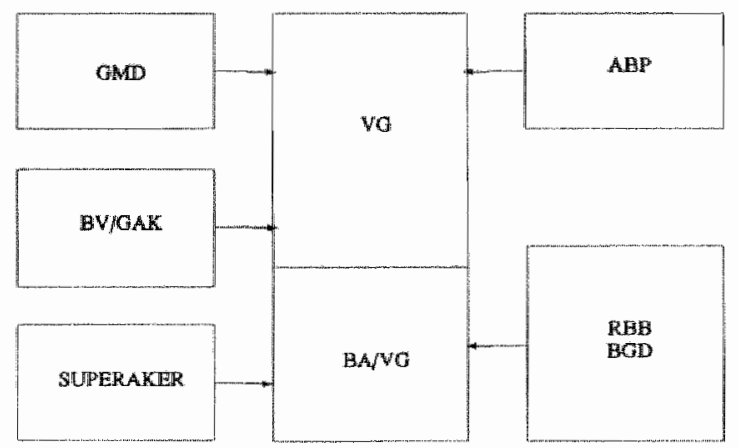

Figuw 5 Uitwoeringsorganisaties en soorten artsen 
On de taken van de artsen bimnen de verschillende uitvoeringsorganisaties te kunnen beschriven, wordi onderscheid gemaakt tussen:

1. Arsen, die uitsluitend een verzekeringsgeneeskundige taak uitoefenen: vg'n.

2. Artsen, die een gecombineerde bedriffsgezondheidskundige en verzekeringsgeneeskundige taak uitoefenen: bafvg'n.

In de paragrafen 1.4 en 1.5 zullen de taken van deze artsen bij de witwoering van de ziektewer en de uitvoering van de rechtspositionele regelingen ten behoeve van ambtenaren beschreven worden. De taken van de vg'n werkzaam bij de GMD en het ABP blijwen in het kader van deze studie onbesproken.

\subsection{De taak van de verzekeringsgeneeskundige}

\subsubsection{Inleiding}

Zoals in de voorgaande paragrafen beschreven, is er in Nederland wat de ontwikkeling van de sociale verzekeringen betreft sprake van een min of meer gescheiden ontwikkeling voor ambitenaren en niet-ambtenaren. Met name in de opbouw van de uitvoeringsorganisaties komt dit tot uiting. Ook in de taken van de in de verschillende uitvoerings organisaties werkzame artsen is deze gescheiden ontwikkeling herkenbaar. Waar bij de uitvoeringsorganisaties ten behoeve van ambtenaren het accent vooral (niet uitsluitend!) lag en ligt op de preventie (RGD, 1982), werd en wordt de uitvoering van de sociale verzekeringen voor werknemers in de private sector vooral gekenmerkt door de grote aandacht woor het controleaspect.

Het zal gezien de ontstaanshistorie geen verwondering wekken, dat de artsen, belast met de verzumbegeleiding van ambtenaren, zich vooral oriënteren op de bedrijfsgezondheidszorg, war de preventie wan oudsher reeds een centrale plaats heeft ingenomen (RGD, 1982). Zij worden dan ook niet zozeer beschouwd als vg'n, maar veeleer, zoals zij zichzelf ook aanduiden, als ba'n, zij het met een verzekeringsgeneeskundige taak. De discussie over het als te hoog ervaren ziekteverzuim in Nederland en het streven naar cen daling van het ziekteverzuim leiden momenteel tot een herbezinning wat betreft de taken bij $\mathrm{vg}^{\prime} \mathrm{n}$ en ba'n. Dit laidt ertos, dat ba $\mathrm{n}$ zich in toenemende mate richten op de verzumbeoordeling en begeleiding; vg " $n$ daarentegen richten hun aandacht steeds meer op de preventie. Bij de beschrijving van de taken van de vg - de controlerende, beoordelende en reintegrerende taken - wordt uitgegaan van de taken, die $\mathrm{gg}^{\mathrm{n}} \mathrm{n}$ in dienst van de Bedrijfswerenigingen ten behoeve van de uitvoering van de ziektewet hebben en met mame op basis van de theorievorming die daarover de laatste jaren tot stand is gekomen (par. $1.4 .2 \mathrm{t} / \mathrm{m}$ 1.4.4). In paragraaf 1.4 .5 wordt vervolgens ingegaan op de taak van de $\mathrm{vg}$ en de ba/vg in dienst van of werkend namens de $\mathrm{BV}$.

De sociale verzekeringswetten zoals de ziektewet $(Z W)$, de wet op de arbeidsongeschiktheidsverzekering (WAO) en de algemene arbeidsongeschiktheidswet (AAW) vereisen bij de uitvoering een aantal medische en niet medische beoordelingen: 
1. Allereerst dient beoordeeld te worden of een verzekerde voldoet aan de toelatingsvoorwaarden. Hiertoe behoort een antwoord op de vraag of men tot de "kring van verzekerden" behoort en loonvormende arbeid heeft verricht. Indien geen loonvormende arbeid wordt verricht, zoals het geval is bij bijvoorbeeld onbetaalde vrijwilligers, behoort men niet tot de "kring der verzekerden" en komt men derhalve niet woor een uitkering in aanmerking, ook als er wegens ziekte of gebrek sprake is van arbeidsongeschiktheid.

2. Behoort betrokkene wel tot de kring der verzekerden, dan is een antwoord op de vraag of er sprake is van arbeidsongeschiktheid door ziekie of gebrek noodzakelijk: hier start de verzekeringsgeneeskundige beoordeling. Timmer (1985a) formuleert dit abstracter: "de vaststelling dat een verzekerd object beschadigd is door ziekte of gebrek". Hoewel in deze definitie het benoemen van de verzekerde als object wel erg kil en beperkt is, gaat het hier in feite om de vaststelling van ziekte en/of gebreken op grond waarvan de verzekerde zijn arbeid tijdelijk of blijvend niet meer kan verrichten. Indien zulks het geval is, komt een verzekerde in aanmerking voor een uitkering, mits er voldaan wordt aan bepaalde voorwaarden.

3. Alvorens tot uitkering kan worden overgegaan moet worden vastgesteld of bepaalde rechtsregels moeten worden toegepast. De belangrijkste is ongetwijfeld de vaststelling dat de arbeidsongeschiktheid niet reeds bestond bij aanvang van de verzekering dan wel binnen een half jaar na aanvang van de verzekering te verwachten was. Indien het antwoord op deze vragen bevestigend is, kan de Bedrijfsvereniging uitkering weigeren juist omdat er sprake van arbeidsongeschiktheid was en is. Daar bij de uitvoering van de ziektewet zwangerschap gelijkgesteld wordt met ziekte, geldt deze bepaling ook, als de arbeidsongeschiktheid veroorzaakt wordt door zwangerschap. In de praktijk wordt evenwel slechts uitkering geweigerd, als er sprake is van mallifiditeit (de zwangere is gaan werken met het oogmerk on een uitkering te verkrijgen); vermoedelijk wordt deze bepaling in de nabije toekomst niet meer van toepassing verklaard in geval van zwangerschap.

Ook dient in voorkomende gevallen vastgesteld te worden of een verzekerde zich onder behandeling stelt, de genezing niet belemmert en zich houdt aan de voorschriften van de huisarts of specialist. Zeker zo belangrijk is de verzekeringsgeneeskundige reïntegratie, gericht op het vergroten van de kans op en zo mogelijk het realiseren van een werkhervatting. De $\mathrm{vg}$ is echter door de scheiding van controle en behandeling afhankelijk van de curatieve sector en beschikt door de vaak geringe samenwerking en afstermming met de curatieve sector over beperkte mogelijkheden tot of ondersteuning van de reïntegratie.

4. Tot de taak van de vg behoort dan ook tevens de beoordeling van het adequat zijn van de schade verminderende maatregelen. Indien de $\mathrm{vg}$ van mening is dat deze maatregelen niet adequaat zijn, zal hij trachten in overleg met de betrokken huisarts of specialist een bijsturing tè bewerkstelligen. Naast de genezing van de pa- 
tient zal de vg ook oog dienen te hebben voor het effect daarvan op de vergroting van de arbeidsgeschiktheid.

5. Tot slot dient te worden wastgesteld of voldaan wordt aan de beerndigingswoorwarden. Het betreft hier een vertekeringsgeneeskundige en wetstechnische vraag. De vg zal een antwoord moeten geven op de vraag of de ziekte of het gebrek in zodanige mate geweken is, dat de verzekerde weer geschikt is voor zijn arbeid. Daarnaast dient vastgesteld te worden of de door de wet gestelde maximum termijn, waarower een uitkering kan worden genoten, niet overschreden wordt. Indien zulks het geval is, wordt de uitkering van rechtswege beëindigd.

Bij het proces van uitwoering worden uit de bovengenoemde taken af te leiden juridische, economische, sociale, medische en ergonomische oordelen gevraagd. Het beoordelen van de fysieke en psychische aspecten van de arbeidsongeschiktheid, zowel als van de adequaatheid wan de maatregelen, vergt een verzekeringsgeneeskundig oordeel. Het beoordelen van de juridische, socialle en economische aspecten wordt meestal door anderen verricht. Het verzekeringsgeneeskundig oordeel is hoe dan ook een noodzakelijk onderdeel van de beoordeling.

De verzekeringsgeneeskundige beoordaling werd vanaf de jaren vijftig verricht door controle-artsen in dienst van of werkend in opdracht van de uitvoeringsorganisaties. Deze controle-artsen deelden het resultat van hun beoordeling mede aan de uitwoeringsorganisaties. Daarmee was hun taak feitelijk beëindigd (Kagenaar, 1985).

Deze wijze van functioneren is heden ten dage niet meer nogelijk.

Niet alleen de toenemende complexiteit van de sociale wetgeving, maar ook accentverschuivingen in het beoordelingsproces leidden tot andere taken; de controlle-arts evolueert tot $\mathrm{wg}$. Naast het beoordelen van arbeidsongeschiktheid krijgt de reintegratie in het arbeidsproces toenemende aandacht; naast het beoordelen van het individu strekt de belangstelling zich meer en meer uit naar de preventie van het ziekteverzuim (NVVG, $1987 \%$.

Onder invloed van deze veranderingen heeft de verzekeringsgeneeskunde zich binnen het specialisme sociale geneeskunde ontwikkeld tot een erkende tak. Nog wel een jonge tak, hetgeen zich onder andere wit in het ontbreken dan wel het nog in ontwikkeling zijn van een verzekeringsgeneeskundig referentiekader. In een dergelijk referentiekader zouden de taken en gehanteerde begrippen voor vg'n zelf énduidig en inzichtelijk moeten worden angegeven.

Een eerste integrale beschrijving van het verzekeringsgeneeskundig referentiekader is beschreven door Timmer (1985a, 1985b).

Onderstand wordt dit referentiekader voorzover relevant in het kader van deze studie besproken. Dit referentiekader is gebaseerd op de dagelijkse verzekeringsgeneeskundige praktijk en kan mede als uitgangspunt dienen voor het de beschrijving van het handelen wan de $\mathrm{vg}$. 


\subsubsection{De verzekeringsgeneeskundige beoordeling}

De verzekeringsgeneeskundige beoordeling is volgens Timmer (1985a, 1985b) te onderscheiden in de volgende stappen:

1. De verzekeringsgeneeskundige oordeelsgang bij het beoordelen van een eventuele arbeidsongeschiktheid gaat uit van de op professionele wijze vastgestelde ziekte en/of gebrek bij de betrokkene.

2. In tweede instantie worden de stoornissen in verzekeringsgeneeskundige zin die door de ziekte zijn ontstaan of uit het gebrek voortkomen door de vg zoveel mogelijk door eigen onderzoek vastgesteld en geregistreerd.

3. Vervolgens worden de gevolgen van de stoornissen in verzekeringsgeneeskundige zin nagegaan op hun invloed op het arbeidsvermogen wat betreft de beroepsvaardigheden, de persoonlijkheidskenmerken (mijns inziens is het beter te spreken van psychische kenmerken) en de lichamelijke kenmerken. Deze drie laatste categorieën omvatten de mogelijkheden en kwaliteiten in materiële en immateriële zin die betrokkene bezit en deze zijn tezamen de krachten en bekwaamheden warmee de arbeid wordt uitgevoerd.

4. Daarna volgt een confrontatie met de werkuitworingseisen van het laatst verrichte werk (ZW) of het referentieberoep (AAW/WAO) enerzijds en het aanwezige, eventuele ondanks ziekte en/of gebrek nog resterende arbeidsvermogen anderzijds. Is het arbeidsvermogen toereikend, dan is er sprake wan arbeidsgeschiktheid voor het betrokken beroep. Onder referentieberoep verstaat men datgene, wat men op grond van opleiding en werkervaring als beroep kan aanmerken.

5. Als het arbeidsvermogen niet toereikend is voor het laatstelijk verrichte beroep of het referentieberoep dan kan worden nagegaan of er andere beroepen zijn, waarvan het geheel van de werkuitvoeringseisen valt binnen de grenzen van het resterend arbeidsvermogen. Dit zoeken naar andere passende beroepen, de reimtegratie in het arbeidsproces, geschiedt onder andere door de arbeids(des)kundige.

\subsubsection{Verzekeringsgeneeskunde in de dagelijkse praktijk}

De in de vorige paragrafen beschreven verzekeringsgeneeskundige taken en beoordelingsstappen zijn gevat in het verzekeringsgeneeskundig referentiekader, zoals door Timmer (1985a, 1985b) beschreven. De vraag rijst echter in hoeverre dit theoretisch model door vg'n wordt herkend en erkend in de dagelijkse praktijk. Hanteren zij de door Timmer aangereikte begrippen? Hieraan mag worden getwijfeld. In gesprekken met $\mathrm{vg}$ ' $\mathrm{n}$ zullen begrippen als stoornis in verzekeringsgeneeskundige zin, arbeidsvermogen en werkuitvoeringseisen zelden gebruikt worden. Dit heeft te maken met onbekendheid met het model, maar nog veel meer met de dagelijkse verzekeringsgeneeskundige praktijk, waarbij het gaat om de vraag of een verzekerde redelijkerwijs in staat kan worden geacht het eigen werk te doen of, anders gezegd, of en in welke mate hij/zij arbeidsgeschikt of arbeidsongeschikt is. 
Hoewel wg'n alle in het referentiekader beschreven taken uitvoeren, kunnen er toch grote accentverschillen bestaan. Deze accentverschillen ontstaan door verschillen in uit te voeren wetten (ziektewet, ambtenarenwet) en verschillen in regelgeving tussen de uitvoeringsorganisaties.

Vg"n zijn belast met de uitvoering van de arbeidsongeschiktheidswetten: de zicktewet (ZW) of de algemene arbeidsongeschiktheidswet/wet op de arbeidsongeschiktheidswerzekering (AAW/WAO), nooit beide soorten wetten tegelijkertijd.

De advisering in het kader van de ziektewet is opgedragen aan de vg van of namens de Bedrijfsvereniging.

De advisering in het kader van de AAW/WAO daarentegen is opgedragen aan de $\mathrm{vg}$ " $\mathrm{n}$ van de Gemeenschappelijk Medische Dienst. De vg van de Bedrijfsvereniging zal aandacht moeten geven aan het kortdurend én langdurend verzuim. Hij vervult een expliciet toegangsbewakende taak zowel ten aanzien van de $\mathrm{ZW}$ als de AAW en WAO. De vg van de Gemeenschappelijk Medische Dienst zal zijn aandacht vooral richten op het langerdurend verzuim.

De taak wan de vg in de uitvoeringsorganisatie sociale verzekeringen, de bedrijfsverenigingen, behelst de adwisering ten behoeve van de uitvoering van de ziektewet.

De doelstellingen van de bedrijfsverenigingen - het voorkomen van onterecht en vermijdbaar verzuim - vinden hun weerklank in de taak van de vg, die als volgt omschreven kan worden:

- het vaststellen van het bestaan van arbeidsongeschiktheid voor zijn/haar arbeid ten gevolge van ziekte of gebrek;

het treffen van maatregelen ter beperking van de arbeidsongeschiktheidsduur en ter realisering van een reïntegratie in het arbeidsproces, en

- het adviseren van aangesloten bedrijven met betrekking tot het treffen van verzuim-voorkomende en verzuim-beperkende maatregelen.

In deze drie taken herkennen wij respectievelijk het van oudsher bestaande controletaak, de reïntegrerende en de preventieve taak van de $\mathrm{vg}$. $\mathrm{Zij}$ worden aangeduid als sociaal medische begeleiding (LHV, LVSG, 1986).

Bij de uitvoering van de ziektewet zal het accent zowel op de controle en beoordeling als op de rë̈ntegratie liggen; bij de uitvoering van de AAW/WAO zal daarentegen de reỉntegratie meer centraal staan. De $v g$, belast met de uitvoering van de AAW/WAO wordt hierbij ondersteund door een arbeids(des)kundige. Onder invloed van het streven naar een daling van het ziekteverzuim en het volume arbeidsongeschikten zijn deze accenten alan het verschuiven: bij de uitvoering van de ziektewet wordt steeds meer aandacht gegeven aan reïntegratie en preventie, terwijl bij de uitvoering van de AAW/WAO in toenemende mate aandacht wordt gegeven aan de beoordeling: het toekennen of beëindigen van de uitkering.

Uitvoeringsorganisaties verschillen in de wijze, waarop de verzekeringsgeneeskundige beoordeling en begeleiding gerealiseerd wordt. Zelfadministrerende bedrijfsverenigin- 
gen kunnen gebruik maken yan vg'n en/of huisartsen. Het Gemeenschappelijk Administratiekantoor maakt uitsluitend gebruik van (geregistreerde) $\mathrm{vg}^{5} \mathrm{n}$.

Huisartsen, die naast hun curatief werk ook een verzekeringsgeneeskundige taak hebben, kunnen in een belangenconflict komen: moeten zij de belangen van de patiënt of de bedrijfsvereniging laten prevaleren? Vermoedelijk zal voor hen het curatieve referentiekader overheersen.

Daarnaast kunnen verschillen in de verzekerde populaties tussen de zelfadministrerende bedrijfsverenigingen leiden tot accentverschillen in de uitvoering van de verzekeringsgeneeskundige taken. Deze verschillen betreffen de aard van de werkzaamheden en de daarmee samenhangende belasting en ziekten. Het begeleiden van werknemers in de bouw vraagt door de specifieke werkomstandigheden een andere aanpak dan het begeleiden van bijwoorbeeld werknemers in het bank- en verzekeringswezen.

Het hiervoor beschreven verzekeringsgeneeskundig referentiekader en de daaruit afgeleide stappen van de verzekeringsgeneeskundige beoordeling behoeven een aanpassing, zodanig dat zij in de dagelijkse praktijk gehanteerd kunnen worden en bruikbaar worden voor de meting van het verzekeringsgeneeskundig handelen.

De behoefte on meer inzicht te krijgen in het verzekeringsgeneeskundig handelen bestaat all veel langer. Jaren geleden reeds heeft de medische dienst van het GAK, om meer inzicht te krijgen in het verzekeringsgeneeskundig handelen en om instrumenten te ontwikkelen tot sturing ervan, een praktisch, direct op de dagelijkse praktijk geënt, registratiemodel ontwikkeld. Sedert 1983 coderen vg'n van het GAK dagelijks hun handelen volgens dit standaardmodel. Dit model is vanwege zijn bewezen bruikbaarheid in de dagelijkse praktijk als uitgangspunt gekozen voor de meting van het verzekeringsgeneeskundig handelen. Tevens is dit model te beschouwen als een operationalisering van de theoretische beschrijving van het verzekeringsgeneeskundige handelen. Het model onderkent de volgende stappen in de verzekeringsgeneeskundige beoordeling:

1. hoofddiagnose: de diagnose, die de op dat moment bestaande arbeidsongeschiktheid veroorzaakt. Dit komt overeen met het vaststellen van de ziekte en/of gebrek uit het theoretisch model.

2. nevendiagnose: de nà de hoofddiagnose meest relevante eventueel te stellen tweede diagnose.

3. beperkingen: de door ziekte en/of gebrek (hoofddiagnose) veroorzaakte beperkingen in belastbaarheid.

4. conclusie: de verzekeringsgeneeskundige conclusie, waarin word weergegeven of er sprake is van ziekte en/of gebrek en/of arbeidsongeschiktheid.

Stap 3 en 4 komen bevatten het vaststellen van de aanwezigheid van een stoornis in verzekeringsgeneeskundige zin, het effect daarvan op het verzekerd arbeidsver- 
mogen en een confrontatie met de werkuitwoeringseisen, uitmondend in een oordeel over het al of niet bestaan van arbeidsongeschiktheid.

5. begeleidingsplan: de activiteiten, die de vg gaat ontplooiern naar verzekerde, curatieve sector en/of werkgever en die tot doel hebben de arbeidsongeschiktheid te verminderen of op te heffen en een reïntegratie in het arbeidsproces te bereiken.

6. prognose: de visie van de vg op het moment van beoordeling met de betrekking tot de eventuele werkhervatting in de toekomst.

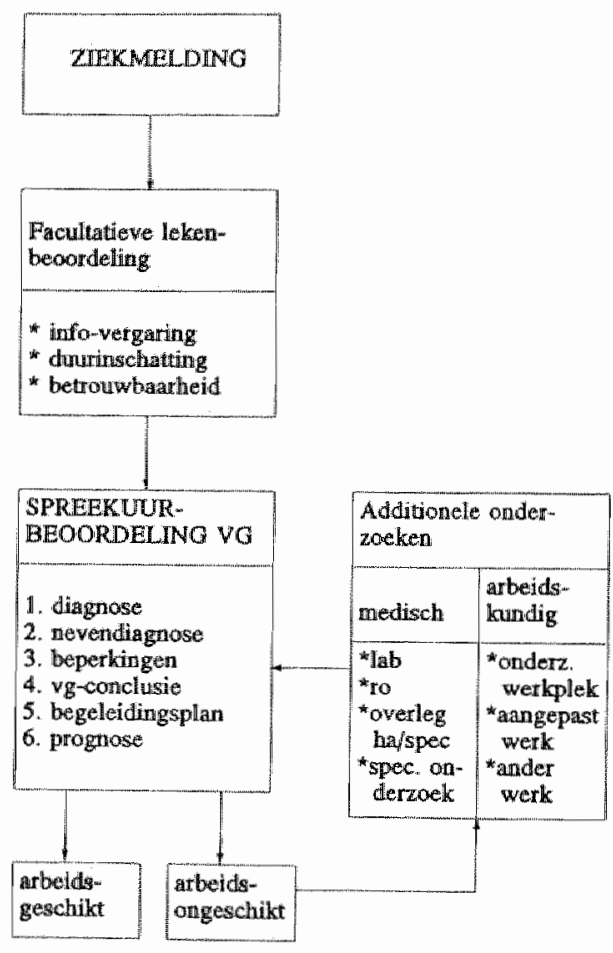

Figuur 6 Schematisch overzicht van verzekeringsgeneeskundig handelen, inclusief facultatieve lekenheoordeling

In figuur 6 is het verzekeringsgeneeskundig handelen, inclusief de facultatieve lekenbeoordeling, schematisch weergegeven.

Tot slot een korte opmerking over de relatie verzekeringsgeneeskunde - curatieve geneeskunde. 
Het kernobject van de verzekeringsgeneeskunde, aldus Timmer $(1985 \mathrm{a}, 1985 \mathrm{~b})$ heeft, zoals uit het overzicht van verzekeringsgeneeskundige begrippen blijkt, een tweepolige structuur. Aan de ene zijde staan de ziekten en gebreken, aan de andere zijde staan het arbeidsvermogen en de werkuitwoeringseisen. In de curatieve medische opleiding wordt zeer uitvoerig aandacht besteed aan ziekten en gebreken. De $\mathrm{vg}$ zal zich in zijn voortgezette opleiding zeer indringend moeten verdiepen in en kennis verwerven van alle bekende ziekten en gebreken in relatie tot alle in ons land voorkomende beroepen en het in een specifiek beroep vereiste arbeidsvermogen. De verzekeringsgeneeskunde is een specifieke toepassingswetenschap. Bovendien zal de $\mathrm{vg}$ de onderlinge relatie tussen ziekte en gebrek enerzijds en arbeidsvermogen anderzijds als selectiecriterium moeten gebruiken. De verzekeringsgeneeskunde heeft raakvlakken met en onderhoudt werkrelaties met de curatieve geneeskunde, de bedrijfsgezondheidszorg, de arbeidskunde en technologische revalidatie (Heuperman, 1986). De beofenaar van de verzekeringsgeneeskunde kan zich derhalve geen specialisatie veroorloven zoals vereist voor een aspect-wetenschap (immunologie, oogheelkunde).

\subsection{De taak van de bedrijfsarts/verzekeringsgeneeskundige in de uitvoeringsorganisaties}

Zowel de uitvoeringsorganisaties van sociale verzekeringen voor werknemers in de private sector, de bedrijfsverenigingen, als die voor de overheidssector, de RBB, GGD'n/ DGD'en of BGD, maken gebruik van ba/vg'n. Hieronder verstaan wij al dan niet als ba geregistreerde sociaal geneeskundigen, die naast hun bedrijfsgeneeskundige taak ook een verzekeringsgeneeskundige taak vervullen.

$\mathrm{De} b a / v g ' n$, die belast zijn met de uitwoering van sociale verzekering ten behoeve van werknemers in de private sector, i.c. de ziektewet, zijn werkzaam binnen een aan een bedrijf (superaker) verbonden enkelvoudige of ten behoeve van het bedrijf ingeschakelde gemeenschappelijke bedrijfsgeneeskundige dienst of bedrijfsgezondheidsdienst. Zij verrichten hun werk in het kader van de betreffende bedrijfsvereniging of het GAK. De taak van deze ba/vg'n in het kader van de uitvoering van de ziektewet komt overeen met de taak van de vg in dienst van de BV of het GAK. Uiteraard zal het feit, dat zij zowel een $\mathrm{vg}$ als bedrijfsgeneeskundige taak hebben, van invloed zijn op de werkwijze en leiden tot accentverschillen bij de uitwoering.

De ba/vg' $n$, belast met de uitvoering van de arbeidsongeschiktheidsregelingen ten behoeve van ambtenaren zijn werkzaam binnen de Rijks Bedrijfsgezondheids- en Bedrijfsveiligheidsdienst (RBB), gemeentelijke of districtsgezondheidsdiensten (GG \& GD, DGD) of bedrijfsgezondheidsdiensten. Hun taken ontlenen zij aan de ambtenaren wet en de verschillende rechtspositionele reglementen (onder andere het Algemeen Rijksambtenarenreglement, ARAR). De wijze van taakuitvoering heeft door de combinatie van bedrijfsgezondheidszorg en verzekeringsgeneeskundige taken een sterk accent op de bedrijfsgezondheidszorg. 
In de paragrafen 1.5 .1 en 1.5 .2 zullen de belangrijkste verschillen in taken van de ba/vg"n belast met de uitwoering van de ziektewet en de ambtenarenwet/ARAR beschreven worden.

\subsubsection{Taken bedriffsarts/verzekeringsgeneeskundige bij de uitvoering van de niektewel}

De taken wan de ba/vg, voortvloeiend uit de ziektewet, komen overeen met die van de vg van BV of GAK. De verschillen witen zich vooral in de taakuitvoering, die voor wat betreft de ba/wg sterk wordi beïnvloed door diens bedriffsgezondheidszorgtaken. De baivg zal zich meer richten op de begeleiding van de individuele werknemer en de preventie. De begeleiding wordt dan ook gekenmerkt door het weelal ontbreken wan het controle-aspect en een zwaarder accent op het zorg-en begeleidingsaspect. Het zwaartepunt van de activiteiten ligt bij het bedrijfsgezondheidskundig spreekuur (De Winter/Dijkstra, 1984). Er bestaat grote aandacht voor ziektegedrag (verzuim, doktersbezoek, medicingebruik).

\subsubsection{Taken bedrijfsarts/verzekeringsgeneeskundige bij de uitvoering van de ambtenarenwet en additionele regelingen}

Op grond van de ambtenarenwet en de verschillende rechtspositionele reglementen (zoals bijvoorbeeld het ARAR) kunnen ambtenaren bij arbeidsongeschiktheid rekenen op loondoorbetaling. De ba/vg adviseert bij arbeidsongeschiktheid de werkgever met betrekking tot het al of niet bestaan wan arbeidsongeschiktheid.

De ba/vg richt zich dan ook vanuit zijn bedrijfsgezondheidskundige taken primair op de individuele ambtenaar. Wat de uitvoering betreft bestaat er grote gelijkenis met de balvg belast met de uitvoering van de ziektewet.

\subsection{Probleembespreking}

In het eind van de jaren zeventig richtte de provincie Limburg in het kader van de voorbereiding van de Perspectievennota Limburg zich tot de Rijksumiversiteit Limburg met het verzoek om een onderzoek in te stellen naar de sociaal-economische en sociaal-medische factoren, die van invloed zijn op de afwezigheid wegens ziekte in het Herstuctureringsgebied. Redenen hiervoor waren het ten opzichte van andere provincies en vooral het omringende buitenland hoge ziekteverzuim en de mogelijk nadelige invloed hiervan op Zuid-Limburg als investerings- en westigingsgebied voor bedrijven. In vervolg hierop verzocht de provincie aan de Rijksuniversiteit Limburg mede te werken aan en diagnosestellend rapport over het voorkomen en de oorzaken van het ziekteverzuim in Zuid-Limburg.

De eerste bevindingen kwamen in 1980. Soeters (1980a) constateerde dat werknemers in Zuid-Limburg niet vaker verzuimden dan werknemers elders in Nederland. Wel verzuimde men, als men zich eenmaal had ziekgemeld, langer dan elders in Nederland. 
Ten aanzien van de mogelijke oorzaken werd het volgende gesignaleerd:

a. de gezondheidstoestand van de werknemers in Zuid-Limburg is (naar verhouding) minder goed dan die van hun landgenoten. Zuid-Limburgers hebben een hogere sterftekans en leggen meer riskante leefgewoonten aan de dag dan elders.

b. relatief veel Zuid-Limburgse werknemers komen via de ziektewet en de wet op de arbeidsongeschiktheidsverzekering terecht in het bestand van niet-actieven.

c. de voorzieningen op het gebied van de gezondheidszorg waren in 1979 in ZuidLimburg minder goed ontwikkeld; het beroep op die voorzieningen daarentegen was in deze regio juist groter.

Met name de langere verzuinduur was reden tot nader onderzoek.

Onderzoek van Tordoir e.a. (1978) had reeds vastgesteld, dat ca. $20 \%$ van alle ziektedagen bij ziektegevallen langer dan 6 weken uit zogenaamde wachtdagen bestond. Tijdens deze wachtdagen werd er geen voortgang in de behandeling van de ziekte geboekt. Verondersteld werd dat als gevolg van deze wachtdagen het herstel en de werkhervatting later zou optreden. De ziekteperioden zouden hierdoor langer duren dan strikt noodzakelijk was.

Gelet op de bevindingen betreffende het aanbod en gebruik van gezondheidszorgvoorzieningen in Zuid-Limburg, was er reden te veronderstellen dat de wachttijden-problematiek hier een grote rol zou spelen. Soeters (1983) onderzocht de verzuimduur-verlengende factoren, die in de interactie tussen patiënt en gezondheidszorg kunnen ontstaan. Dit onderzoek leverde de volgende bevindingen:

de netto-wachttijd in Zuid-Limburg ligt 2,6\% hoger dan in de Randstad, vermoedelijk als gevolg van de hogere opnamecoëfficiënt en minder sturende GAK vg'n.

de indruk bestaat dat vg'n nogal gedifferentieerd te werk gaan, afhankelijk van de organisatorische context, waarin zij werkzaam zijn. Zo bestaan er verschillen in de frequentie, waarmee vg'n contact hebben met hun verzekerden, alsmede de wijze waarop vervolgcontacten tot stand komen.

de verwijzingskans van eerste naar tweede lijnszorg is groter naarmate het aantal specialismen in het meest nabije ziekenhuis groter is en de behandeling in het begin van de ziekteperiode als onduidelijker wordt ervaren.

stuurloze dagen (dit zijn dagen zonder dat een koers voor verdere behandeling is uitgezet) komen vooral voor bij werknemers, die een aandoening zonder verleden hebben of een aandoening, die wijst op een algemene malaisetoestand.

ziekenfondsverzekerden en zieke werknemers met een geringe arbeidssatisfactie maken relatief veel stuurloze dagen mee.

Soeters merkte bovendien op dat dit onderzoek veel stof tot discussie gaf. Dit werd nog versterkt door het feit dat het onderzoeksterrein weinig geëxploreerd was. Om verschillen in behandelingskenmerken zoveel mogelijk te elimineren, raadde hij aan vervolgonderzoek te beperken tot patiënten met omschreven diagnosen. Aanvullend adviseerde hij niet slechts gebruik te maken van informatie van de kant van de patiënt. 
Door de patiênt als enige informatiebron te gebruiken ontstaat een onduidelijk beeld van thet handelen van de artsen. Daarnaast ontbreekt ieder zicht op de contacten tussen de betrokken artsen: de huisarts, de specialist, de ba en de vg.

De aanbeveling werd gedaan een vervolgonderzoek uit te laten gaan van het gezichtspunt van de artsen. Vele artsen zijn betrokken bij de begeleiding van langdurig zieke werknemers; dataverzameling bij al deze artsen is bijzonder moeilijk. Soeters (1983) adviseerde, als alternatief, de dataverzameling bij één soort arts te doen plaatsvinden, bijvoorbeeld de huisarts, de ba, de vg etc.

Gelet op de centrale rol, die de vg bij de beoordeling op de rechtmatigheid van afwezigheid wegens ziekte vervult, het ontbreken van fundamenteel onderzoek naar thet handelen van de vg en de aanwijzingen voor een sterk gedifferentieerd werkwijze van vg'n, werd voorgesteld vervolgonderzoek te richten op het handelen van de vg'n.

Het onderhavige onderzoek is een vervolg op genoemd onderzoek van Soeters. Zijn aanbevelingen met betrekking tot vervolgonderzoek zijn ten dele gevolgd. Om praktische redenen is afgezien van uitbreiding van het onderzoeksgebied over Nederland. Gekozen is voor Zuid-Limburg als onderzoeksgebied.

Onderwerp van onderzoek is het handelen van twee categorieën artsen: de vg en de $\mathrm{ba} / \mathrm{vg}$. Daar er een samenhang verwacht mag worden tussen het handelen van artsen en hun taakopvattingen (Boots, 1983), is tevens onderzoek verricht naar de taakopvattingen van de twee categorieën artsen. Tevens is van de mogelijkheid gebruik gemaakt dit onderzoek naar de taakopvattingen uit te breiden tot een derde categorie arts: de ba.

Dit maakt het mogelijk naast het in kaart brengen van het handelen van genoemde artsen naar aard en effect ook de verschillen te benoemen naar aard en effect. Met betrekking tot dit laatste is de geringe omvang van het onderzoeksgebied geen nadeel: variabelen met betrekking tot het gezondheidszorgaanbod zijn voor beide categorieën artsen gelijk. Het handelen van de artsen zal gemeten worden aan de hand van de begeleiding van patiënten uit omschreven diagnosegroepen. Dit maakt een vergelijking van het handelen per diagnosegroep mogelijk.

Hiermede zijn de twee beschrijvende vraagstellingen van dit onderzoek gegeven:

1. Welke activiteiten ontplooien vg'n en ba/vg'n in het kader van de controle en begeleiding?

2. Zijn er verschillen in activiteiten en taakopvatting tussen deze twee groepen artsen?

Daarnaast wordt in deze studie getracht inzicht te krijgen in factoren, die de verschillen in arbeidsongeschiktheidsduur verklaren, middels de volgende twee vraagstellingen:

3a. Zign de verschillen in arbeidsongeschiktheidsduur afhankelijk van de taakopvattingen en activiteiten van de $\mathrm{vg}$ en ba/vg?

3b. Zijn de verschillen in ao-duur athankelijk van de organisatorische context, walarbinnen de $\mathrm{vg}$ en ba/vg werkzaam zijn? 
De antwoorden op dit soort vraagstellingen hebben een grotere reikwijdte dan het geografisch gebied, waarop het onderzoek in kwestie betrekking heeft.

Immers, de relatie tussen de verzuimduur en de factoren, die daarop invloed zijn, kan op overeenkomstige wijze overal worden vastgesteld, waar deze variabelen op dezelfde wijze gemeten kunnen worden. Dit betekent dat de analyses met betrekking tot de determinanten van de arbeidsongeschiktheidsduur niet alleen betekenis hebben voor Zuid-Limburg, maar tenminste voor geheel Nederland (Philipsen, 1969).

Om deze vraagstukken te kunnen bestuderen is het handelen van $35 \mathrm{vg}$ "n en ba/vg'n gevolgd aan de hand van de begeleiding van 495 werknemers, die tenminste 8 weken arbeidsongeschikt waren.

Vg'n en ba/vg'n zijn geïnterviewd om de organisatorische context in kaart te brengen en hun taakopvattingen te registreren. De aan het onderzoek deelnemende patiënten hebben zelfstandig een vragenlijst ingevuld, samengesteld uit vragen naar specifieke kenmerken van de persoon, het arbeidsverleden, de huidige arbeid, eerdere en huidige ziekte en contacten met de gezondheidszorg en werkgever. Bovendien is ieder contact tussen $\mathrm{vg}$ en ba/vg met behulp van een aparte registratie vastgelegd. 

LING

\section{$2.1 \quad$ Inleiding}

Ziekteverzuim is sedert het eind van de jaren veertig in toenemende mate onderwerp wan onderzoek geweest, niet in het minst door de hoge kosten van het ziekteverzuim. Het inzicht in de factoren, die invloed hebben op het optreden en voorturen van ziekteverzuim is enorm gegroeid. Echter, een zodanig inzicht in deze factoren, dat door beïvloeding erwan ziekteverzuim een beheersbaar verschijnsel is geworden, is niet ontstaan. De discussie rond de sociaal-medische begeleiding, die een aanzet moet ge ven tot een andere vorm van begeleiding van arbeidsongeschikten met een betere beheersing van het ziekteverzuim als doel, is hiervan de meest recente uiting (NVAB, 1987; VNO, 1990).

Alle onderzoeken en rapporten van werkgroepen, commissies en individuele onderzoekers in de laatste decennia geven toenemend zicht op de relatie tussen ziekteverzuim en werk- en werkomgevingsfactoren, maatschappelije factoren, sociaal-economische factoren en de curatieve gezondheidszorg.

In dit hoofdstuk wordt nader ingegaan op de literatuur en zullen aansluitend de probleemstellingen, waarop dit onderzoek een antwoord tracht te geven, worden uitgewerkt.

Het onderwerp wan studie, de rol en takuitoefening van $v g^{\prime} n$ en ba/vg' $n$, is geënt op een specifiek Nederlandse situatie. Met uitzondering van Griekenland, is in geen enkel land sprake van een strikte scheiding tussen behandeling en controle (Commission of the European Communities, 1988). Behandeling en controle is overal elders geheel of gedeeltelijk in handen van één en dezelfde arts gellegd. Dit heeft consequenties voor het literatuuronderzoek en het, in een latere fase, toetsen van de onderzoeksbevindingen aar onderzoeksresulaten buiten Nederland. Dit zal veelal niet mogelijk zijn. On deze reden zal het literatuuronderzoek zich wrijwel geheel beperken tot de Nederlandise situatile.

\subsection{Literatuuroverzicht}

Ongetwijfeld zal het grote economische belang van ziekteverzuim debet zijn gewcest aan de sinds de veertiger jaren toenemende aandacht wan onderzoekers voor het onderwerp ziekteverzuim. Het onderzoek van Mayo (1945) naar het optreden van ziekteverzuim in Amerika kan beschouwd worden als de start van een onderzoekstraditie, die sedert het eind wan de veertiger jaren ook in Nederland tot grote bloei is gekomen op initiatief van zowel de overheid en het bedrijfsleven. 
In 1949 werd een commissie opgericht ter bestudering van het ziekteverzum in de Limburgse minondernemingen (Crousen, 1968).

Deze commissie onderzocht de relatie ussen arbeid(somstandigheden) en ziekteverzum centraal. De Groot (1958) verrichte onderzoek naar het verzum van patiënten met neurosen bij Philips en Hoogovens.

Dit onderzoek bevatte de eerste theoretische beschouwing over ziekteverzuin in het Nedarlandse taalgebied (Smulders, 1984).

De Groot formuleerde een viertal, overigens niet scherp gedefinieerde omstandigheden, waarvan hei verzuimgedrag afhankelijk was. Deze omstandigheden kunnen, rekening houdend met de herformulering door Philipsen (1966) als volgt benoemd worden:

1. de verzimbehoefte (de werknemersnorm). Hieronder wordt verstaan het complex aan gevoelens van lichamelijke en/of geestelijke aard wan de werknemer (onwelbevinden), resulterend in een gevoel niet tot werken in stat te zijn en veroorzaakt door de situatie, waarin de werknemer zich bevindt.

2. de verzimnoodzaak, bepaald door de geldende medische en maatschappelijke opvattingen met betrekking tot het feit of men bij een bepaalde aandoening al dan niet ziek en/of arbeidsongeschikt moet worlen beschouwd. Philipsen (1969) noemde dit in zijn proefschrift de subjectieve verzuimnoodzaak, ter onderscheid van de objecheve verzummoodzak. Bij dit laatste doelde hij op het "aanbod" van in arbeidsongeschiktheid resulterende aandoeningen (de hoeveelheid en de ernst), die zich aan een werknemer voordoen.

3. de verzimgelegenheld: het complex aan maatregellen en gewoonten, die remmend of bevorderend werken op de beslissing van een werknemer om te verzuimen. Hieronder vallen wolgens De Groot (1958) de ziektecontrole, de vereiste wijze van ziekmelding, de binding aan collega's en de preventieve activiteiten binnen het bedrijf.

4. de verzummogelijheid. Deze wordt bepaald door de financiële en sociale consequenties van ziek zijn cq. verzuimen voor de werknemer en zijn gezin. Bij financiële consequenties moet gedachi worden aan bijvoorbeeld het aantal wachtdagen, hett uitkeringsniveau, de ontslagkans; bij sociale consequenties moet gedacht worden aan ruzie met of sancties door collega's en/of baas. De Groot rekent hiertoe ook de conomische consequenties.

Tot slot wees De Groot op het verzuim, dat een gevolg was van het handelen van de arts zelf, het zogenaamd iatrogene werzum; een bijzondere worm van verzuimgelegenheid of verzuimnoodzaak.

Opmerkelijk was dat de ook toentertijd reeds opgang doende opvatting, dat verzuim te wijten was aan de veranderde mentaliteit van de werknemers als niet bewezen en te énzijdig van de hand werd gewezen.

De Groot deed tevens aanbevelingen tot het uniformeren van de wijze van verzamelen van verzuim - en diagnosegegevens teneinde de vergelijkbaarheid van de ziekteverzuimen diagnosestatistieken te vergroten. 
Ook het onderzoek, dat Van Hoof en Nas (1967) verrichtten in opdracht van de Maastrichtse Kamer van Koophandel naar het voorkomen van ziekteverzuim in een aantal Mastrichtse ondernemingen, had tot doel het inzicht in het ziekteverzuim in de regio Zuid-Limburg te vergroten. Inmiddels werd steeds duidelijker dat ziekteverzuim door vele factoren beïnvloed en bepaald werd.

Philipsen (1969) presenteerde, voortbouwend op de theorie van de Groot (1958), in zijn proefschrift "Afwezigheid wegens ziekte" een sociaal-psychologische en sociologische verzumtheorie. Wat betreft de sociaal-psychologische verzuimtheorie introduceert hij een beslissingsmodel ter verklaring van het verloop van het modale ziekte cq. verzuimgeval, waarin de volgende fasen worden onderscheiden:

1. de toestand van welbevinden en het optreden van onwelbevinden;

2. de herkenning van gezondheidsproblemen;

3. de bereidheid hulp en/of genezing te zoeken;

4. de aanvaarding van de rol van patiënt;

5. de bestendiging gedurende enige tijd van het rolgedrag van de patiënt, en

6. de afloop van het ziektegeval.

In elke fase van het proces bestaat voor de patiënt een zekere mate van beslissingsvrijheid. Philipsen schat dat bij $75 \%$ van de ziekmeldingen een grote mate van beslissingsvrijheid bestaat. Bij de overige gevallen - de meest ernstige - bestaat deze beslissingsvrijheid vooral ten aanzien van de hersteldatum.

Centraall bij deze theorie staat de beslissingsvrijheid van de werknemer. De werknemer heeft bij bepaalde aandoeningen de vrijheid om de patiëntenrol te aanvaarden en ontheven te worden van de maatschappelijke plichten. Onbelangrijk is of deze keuze al of niet bewust geschiedt. Begrippen als wit, grijs en zwart verzuim werden geïntroduceerd. Wit verzuim kenmerkt zich door een voor iedereen ondubbelzinnig vast te stellen afwezigheidsnoodzaak; van zwart verzuim is sprake als er ook naar het oordeel van de patiënt geen afwezigheidsnoodzaak is. Is er sprake van een grote beslissingsvrijheid dan wordt dit gekenschetst als grijs verzuim. Met name verschillen in aantallen verzuimmeldingen, waarbij de beslissingsvrijheid om al dan niet te verzuimen groot is, zijn hiervan een uiting.

Poelstra (1987) daarentegen twijfelt in zijn publikatie "De fictie van de omvang van het grijze verzuim" aan de invloed van beslissingsvrijheid op het ziekmeldingsproces. Niet de beslissingsvrijheid, maar het ingewikkelde samenspel van objectieve en subjectieve afwezigheidsnoodzaak, afwezigheidsbehoefte en afwezigheidsgelegenheid resulteert in een bepaalde kans op ziek- of herstelmelding. Dit samenspel laat evenwel zien, dat juist de werknemer bij de beslissing tot ziekmelden en herstel melden een grote mate van beslissingsvrijheid heeft, die overeenkomt met de theorie van Philipsen.

In het meer organisatie - sociologische gedeelte van zijn proefschrift gat Philipsen er vanuit, dat een organisatie zijn uiterlijke samenhang ontleent aan bindingskracht (innerlijke samenhang), lok- en dwangmiddelen. Binding of gevoelens van gebondenheid met een organisatie kunnen volgens Lammers (1964) een meer instrumentele of sociale 
inhoud hebben. Zij hebben dus te maken met resp. de taakinhoud of de sociale verhoudingen op hat werk.

Philipsen hanteert de begrippen instrumentele en sociale binding als bepalend voor de verzumbehoefie, die dwangmiddelen als bepalend voor de verzumgelegenheid. Aan deze begrippen voegde Philipsen toe: de verzumnoodzaak, de individuele waardeorientatie van de werknemers en de aandacht van het bedriff voor het individuele verzuimgeval.

De theorie van Philipsen is vooral een inhoudelijke theorie; zij geeft antwoord op de wrag welke factoren het verzuin beïrvloeden. Op de wijze, waarop deze factoren het verzuim beinvloeden (de procestheorie) wordt in veel mindere mate ingegaan.

Philipsen koos in 1977 een andere invalshoek: hij onderzocht de relatie tussen levensfase, generatie en xiekteverzuim. Hij toonde aan dat het verschil in ziekteverzuim bij oudere werknemers bepaald werd door de gezondheidsbeleving; verschillen in ziekteverzum tussen jongeren werd daarentegen bepaald door een verlaagde afwezigheidsdrempel, onbedoelde gevolgen van riskante leefgewoonten en toenemende vrijetijdsbehoefte.

Verbaan (1980) deed verslag van de resultaten van een onderzoek naar ziekteverzuim onder 80.000 werknemers van Philips. Bij het hoogste functieniveau lag het verzuimpercentage op 3,7; bij het latagste functieniveau op 18. Ook Molendijk (1980) vond dergelijke verschillen in ziekteverzuimpercentages, maar dan gekoppeld aan het salarisniveau, bij onderzoek onder 23.000 Rotterdamse gemeenteambtenaren.

Ondanks het besef, dat ziekteverzuim door vele factoren werd bepaald zonder dat bekend was in welke mate welke factor verantwoordelijk was, ontstond er well consensus over de oorzaken en achtergronden. Volgens Smulders (1984a, 1984b) kunnen deze gelegen zijn op een vijftal terreinen: de arbeidssituatie, de persoonlijke levenssfeer, de werking wan de gezondheidszorg en het sociale verzekeringsstelsel, en de algemene sociale, social-culturele en sociaal-economische situatie. Wat de arbeidssituatie betreft introduceerden Draaisma en Smulders (1978) een overzicht van verzuimbeinvlloedende factoren in het bedrijf gegroepeerd volgens een 7 -tal hoofdfactoren:"

1. lichamelijke belastingsfactoren in het werk;

2. binding aan het werk;

3. binding an de werkgroep;

4. binding aan het bedrijf;

5. ontwikkeling van het personeelsbeleid;

6. inhoud van het verzuimbeleid, en

7. gemotiveerdheid voor een verzuimbeleid.

Deze indeling wordt nog steeds gehanteerd en ligt ten grondslag aan het beleid van het Gemeenschappelijk Administratiekantoor inzake risicobeperking: het bewerkstelligen van verzuindaling door beinvloeding van verzuimbevorderende factoren in het bedrijf. 
Nijhuis en Soeters (1982) onderzochten in opdracht van het Provinciale Bestuur Limburg welke sociaal-economische en sociaal medische factoren van invloed zijn op de afwezigheid wegens ziekte in het Herstnctureringsgebied (i.c. Zuid-Limburg). De probleemstelling van het onderzoek werd toegespitst op de relatie tussen organisatiekenmerken en de verschillen in afwezigheid wegens ziekte en arbeidsongeschiktheid. Overduidelijk kwam naar voren dat verbetering van de kwaliteit van de arbeid, immaterieel, materieel en de vereiste (persoonlijke) kwalificatie voor de arbeid tot een vermindering van het ziekteverzuim leiden. Ook activiteiten, die de werkbinding bevorderen, een kwalitatief goed personeelsbeleid, een adequate personeelsbezeiting en arbeidsplaatsverbetering hebben een vermindering van ziekteverzuim tot gevolg.

Niet alleen de relatie tussen arbeid, bedrijf en ziekteverzuim, maar ook individuele aspecten als leefgewoonten waren onderwerp van onderzoek. Leefgewoonten als roken, drinken, eten, sporten en andere vormen van vrije tijdsbesteding hebben behalve op de gezondheidstoestand van het individu ook invloed op diens ziekteverzuim (De Pater, 1982). Hieraan kunnen nog factoren als geslacht, leeftijd, burgerlijke staat, nationaliteit, aantal thuiswonende kinderen, reistijd, opleidingsniveau, lengte van het dienstverband, en stedelijkheidsgraad worden toegevoegd (Draaisma en Smulders, 1978).

Reeds in de vijftiger jaren werd de relatie tussen gezondheid en arbeid als een maatschappelijk probleem gezien.

Wat de werkgelegenheidsvooruizichten betreft worden verzuimbeïnvloedende tendensen waargenomen.

a. Een verzuimbeperkende tendens.

Een groeiende werkloosheid gaat gepaard met een daling van het verzuim (Behrend, 1953; Plummer en Hinkle, 1955; Crowther, 1957; Steers en Rhodes, 1978). Slechte algemene economische condities leiden tot een daling van het ziekteverzuim uit angst voor ontslag. Deze verminderde afwezigheid gaat niet op, indien de kans op het vinden van een nieuwe baan erg groot is.

Produktietechnische verbeteringen blijken samen te hangen met een gemiddeld kortere verzuimduur. Deze verzuimbeperkende tendens wordt versterkt door een optimalere benutting van de personeelsbezetting (gezonder personeel) (Nijhuis, 1984a, 1984b).

b. Een verzuimbevorderende tendens.

Kesteloo (1974), Buhring (1977a, 1977b) en Meems (1981) constateren een verzuimverhogende invloed, die uitgaat van een ontslagdreiging. Kruidenier (1981) stelde overigens, dat ook het tegenovergestelde het geval is. Merens-Riedstra (1981) is van mening, dat het niet-kunnen-werken door arbeidsongeschiktheid of werkloosheid een welzijns- en gezondheidsbedreigende werking heeft. Ook Van der Horst (1988) een relatie tussen langdurige arbeidsongeschiktheid en een verslechtering van de gezondheidstoestand. Bijlsma en Koopmans (1984) en Van 't Hullenaar en Van Koningsveld (1986) constateren de ongunstige invloed van reorganisaties en personeelsinkrimping op arbeidsongeschiktheid. Eenzelfde bevinding 
werd gedaan door Van Dijk (1987) die een piek in het aantal toetredingen tot de WAO signaleerde als gevolg van een periode wan werktijdverkorting, gevolg door ingrijperde reorganisates, inkrimpingen en bezuinigingen. Als oorzaak noemt hij het wegvallen van de "lichte" banen. In de periode kort voor de piek in het aantal toetredingen tot de WAO was er evenwel sprake van een dalling van het ziekteverzuim en aantal toetredingen tot de WAO, vermoedelijk als gevolg van werktijdverkorting en verminderde produktie.

Een internationaal vergellikend onderzoek naar verschillen in verzumpercentages tussen verschillende Westeuropese landen en de VS en Canada geeft als oorzaken voor het hogere verzuim in Europa het ontbreken van een ziekteregeling en de hogere werkloosheidspercentages in VS en Canada. Deze inverse relatie tussen werkloosheid en ziekteverzuin werd echter niet altijd gevonden. In een studie naar de relatie tussen de werkloosheid en ziekteverzuim in verschillende Engelse regio"s bleek een hoog werkloosheidspercentage samen te hangen met een hoog ziekteverzuim (Taylor en Pocock, 1969). Een onderzoek naar de relatie tussen ziekteverzuim en werkloosheid in de Nederlandse textielindustrie toont aan dat het ziektewerzuim tijdens perioden van recessie relatief laag is, maar stijgt in de periode nadat ontslag en/of werktijdverkorting heeft plaatsgewonden. Bovendien daalt het ziekteverzuim in perioden van verminderde produktie. De verklaring hiervoor wordt gezocht in de productiviteitsstijging na recessie en ontslag (Buringh, 1977a, 1977b).

Prins (1990) onderzocht de verschillen in ziekteverzuim ussen werknemers in België, West-Duitsland en Nederland, waarbij drie groepen maatschappelijke factoren nader onderzocht werden, te weten: loondervingsregelingen, nortaliteit en social-culturele factoren. De in vergelijking met België en West-Duitsland hoge frequentie van kortdurende gevallen schrijft hij toe aan de ongecompliceerde ziekmeldings- en legitimatieprocedures; het hogere langdurig ziekteverzuim schrijft hij voor een belangrijk deel toe aan de betere ontslagbescherming, het hoge uitkeringsniveau en de relatief soepele toetredingscriteria voor de invaliditeitsverzekering (WAO). Het aantal toekenning ligt een fact twee hoger dan in de ons omringende landen. Tevens valt op de hoge incidenties bij de jongere en middelbare leeftijdsgroepen en voor de diagnosegroepen: psychische ziekten en ziekten van het bewegingsstelsel. De WAO-intreders lijken in vergelijking met de ons omringende landen een relatief gunstige gezondheidstoestand te bezitken

De sterfecijters en de levensverwachting van Nederlanders zijn gunstiger dan in WestDuitsland en Belgie. Het ziektegedrag steekt in bepaalde aspecten, bijvoorbeeld minder artsenbezoek, lager medicijngebruik, gunstig af. Nederlandse werknemers zijn tevredener over hun beloningsniveau en hechten meer warde aan niet-materiële werkaspecten als arbeidssfeer, arbeidsomstandigheden. Nederlandse werknemers hebben een hogere arbeidssatisfactie dan werknemers en Duitsland of België.

Ook de wijze van ziektewet controle wordt als verzuimbeinvloedende factor beschouwd (Draaisma en Sumlders, 1978). Ten aanzien van een strenge ziektewetcontrole wordt geconstateerd dat dit aanleiding kan geven tot meer frequent verzuim, zij het met een 
verkortende werking op de verzuimduur. Hierbij moet worden aangetekend, dat de onderzoeksresultaten niet éénduidig zijn: enerzijds lijkt een aantal van de zeer korte verzuimgevallen te voorkomen, anderzijds treedt door legitimatie een verlenging van het kortdurende verzuim op. Daarnaast bestaat gevaar voor het miet durven verzuimen uit angst voor strenge controle. Ook de toenmalige staatssecretaris De Graaf van Sociale Zaken en Werkgelegenheid (1980) wees erop dat zowell strenge controle als een eigen risico voor de werknemer vermoedelijk weinig effect zullen sorteren. In deze doelde hij op een stijging van het werzuim bij het niet langer betalen van de eerste wachtdag. Ook lijkt de relatie tussen ziekteverzuim en de hoogte van de uitkering twijfelachtig.

Dit geldt evenzeer voor de relatie tussen routinecontrole en ziekteverzuim: het afschaffen van de routinecontrole heeft geen invloed op de verzuimfrequentie van ziektegevallen, die één tot twee weken duren. Ten aanzien van het langdurend verzuim bestaat er een positief verband tussen de verzuimduur en het verzekeringsgeneeskundig-consultpercentage: het aantal contacten tussen $\mathrm{vg}$ en de patiënt per honderd verzuimde dagen (zie ook Smulders en Veerman, 1991). Ook Soeters (1983) signaleert een positieve relatie tussen het aantal contacten en de behandelingsduur.

In 1983 toonde onderzoek wan het NIPG/TNO een verband aan tussen de verzekeringsvorm en de hoogte van het ziekteverzuim (NIPG/TNO, 1983). Dit onderzoek richte zich op bedrijven met tussen de 150 en 1000 werknemers. Bedrijven, die het ziekterisico gezamenlijk dragen (zogenaamde omslagleden) en de controle laten verzorgen door het Gemeenschappelijk Administratiekantoor hadden een ziekteverzuim-percentage van 11; bedrijven, die zelf de financiële gevolgen van het ziekteverzuim ondervinden (zogenaamde Akers, Afdelingskassen en Eigen Risicodragers), toonden een ziekteverzuim, dat 3.5 procent-punt lager lag.

Hierbij moet worden aangetekend, dat de keuze voor een verzekeringsvorm als aker of omslaglid mede wordt bepaald door de verwachting ten aanzien van het ziekteverzuim en de financiële gevolgen ervan.

Naast onderzoek naar factoren, die het optreden van ziekteverzuim kunnen veroorzaken of beïnvloeden ontstond het besef dat niet alleen factoren gelegen in de persoon, het werk of de werkomgeving van invloed waren op het ziekteverzuim, doch ook de interventies vanuit de gezondheidszorg. De sedert de jaren vijftig toenemende stijging van het gebruik van gezondheidszorgvoorzieningen zal hier mede een rol hebben gespeeld.

Sedert de introductie van het begrip "jatrogeen verzuim" zijn vele onderzoeken verricht naar de betrokkenheid van de gezondheidszorg bij ziekteverzuim en arbeidsongeschiktheild (Buys, 1988).

Vele knelpunten kwamen dararbij naar voren, zoals onder andere:

- het overwicht van de tweedelijns-gezondheidszorg;

- het grote aantal verwijzingen naar de tweedelijns-gezondheidszorg;

het groot aantal diagnostische werrichtingen in de tweede-lijnsgezondheidszorg; 
- de geringe aandacht voor preventie, revalidatie, evaluatie van behandelingsmethoden en integrale benadering van de patiënt;

de te optimistische verwachtingen over werkhervatting;

het tekort aan aangepast werk;

onwoldoende wetenschappelijke onderbouwing van het begrip "arbeidsongeschiktheid" en problemen om hiermee in de praktijk te werken; en tekort schietende opleidingen terzake.

Al deze factoren kunnen leiden tot, of tenminste bijdragen aan eer onnodig lang verblijf in de medische circuits, hetgeen op haar beurt kan leiden tot iatrogene invalidering, medicalisering, somatische fixatie en hospitalisering met als gevolg een verlenging van het ziekteverzuim en een toenemende kans op WAO-intrede.

\subsection{De rol van de verzekeringsgeneeskundige in het verzuim}

Voor het eerst kwam in het onderzoek van Soeters (1983) de rol van de vg bij de begeleiding van arbeidsongeschikten uitdrukkelijk aan bod. Opmerkelijk, omdat onderzoeken naar factoren van ziekteverzuim veelal voorbijgingen aan de rol van de $\mathrm{vg}$ en de invloed van de verzekeringsgeneeskundige begeleiding op het ziekteverzuim. Streng (1983) wees in dit kader op het feit, dat behandelend geneesheer en vg te geïsoleerd van elkaar werken. Oorzaken hiervoor zijn onder andere de moeilijke herkenbaarheid en bereikbaarheid van de vg voor de behandelend geneesheer en de complexe structuren van de uitvoeringsorganisatie. In dit verband werd geconstateerd dat het gezamenlijk netwerk van medische diensten van de uitvoeringsorganen sociale verzekering niet in staat is op regionaal niveau én voor de behandelend sector aanspreekbare vg aan te wijzen.

Onderzoekingen naar de oorzaken van ziekteverzuim richten zich vooral op de inhoudelijke theorie en proberen antwoord te geven op de vraag welke factoren het verzuim beïnvloeden. Onderzoek naar ziekteverzuim als proces, waarbij de vraag beantwoord moet worden op welke wijze de verschillende verzuimbeïnvloedende factoren in hun onderlinge samenhang het verzuim beïnvloeden, is grotendeels achterwege gebleven.

Evenals in het verleden worden ook nu de kosten, voortvloeiend uit ziekteverzuim, als te hoog ervaren. Daarnaast wordt de sociaal geneeskundige begeleiding van arbeidsongeschikte werknemers in de praktijk onvoldoende geacht. De bij de begeleiding van arbeidsongeschikte werkmemers betrokken artsen zouden te weinig samenwerken en hun werkzaamheden onvoldoende afstemmen. Met het oog hierop hebben de staatssecretaris van Sociale Zaken en Werkgelegenheid en de statssecretaris van Welzijn, Volksgezondheid en Cultuur in 1983 bij de Nationale Raad voor de Volksgezondheid een adviesaanvraag ingediend. In deze adviesaanvraag worden een drietal modellen, volgens welke de sociaal medische begeleiding van arbeidsongeschikte werknemers wellicht kan worden verbeterd, geschetst: het huisartsenmodel, het verzekeringsgeneeskundig model en het uitgebreid verzekeringsgeneeskundig model (het bundelen van 
bedrijfs- en verzekeringsgeneeskundige kennis in een onafhankelijke dienst). In al deze modellen wordt de coördinatie rond behandeling en werkhervatting bij eén arts gelegd. Daar de opheffing van de scheiding van behandeling en controle onuitvoerbaar en ongewenst wordt geacht wordt het huisartsen- en verzekeringsgeneeskundig-model afgewezen; ook het uitgebreid model wordt ongewenst geacht; immers, het bundelen vam bedrijfs- en verzekeringsgeneeskundige kennis in een onafhankelijke dienst wordt onnodig geacht. Uiteindelijk adviseert de Nationale Raad een bruikbaar eigen model: ongeveer de huidige gang van zaken in optima forma, met een protocol voor moeilijke gevallen, inclusief behandelings- en reïntegratieplannen en informatieuitwisseling ussen curatieve artsen en $\mathrm{vg}^{\prime} \mathrm{n}$ binnen 14 dagen. Echter de vraag rijst of een dergelijke advies realiseerbaar is zonder voldoende betrokkenheid van de uitvoerders: de behan* delend artsen, de vg'n en de ba'n. Kennen de uitvoerders elkanders rol? Kennen ze de eigen rol? De rol van de $\mathrm{vg}$ is voor de behandelend artsen en, in mindere mate, voor ba'n onduidelijk of onbekend. De verzekeringsgeneeskunde is bovendien een jonge tak binnen de sociale geneeskunde: ontstaan na de tweede wereldoorlog is de controlearts door veranderingen in het sociale verzekeringsstelsel uitgegroeid tot vg, die naast de claimbeoordeling het begeleiden naar werkhervatting tot zijn taak rekent.

Hoe werkt de vg in de praktijk? Feitelijk moet geconstateerd worden dat het handelen van de vg"n nooit onderzocht en in kaart is gebracht.

Met name het geringe zicht op en de geringe kennis over de rol van de vg en ba/vg en het door hen gevoerde verzuimbeleid en verzuimbegeleiding vormen de belangrijkste drijfveren voor dit onderzoek en de in paragraaf 2.4 geformuleerde probleemstellingen.

\subsection{Probleemstellingen}

Het aantal interacties tussen arbeidsongeschikte en $\mathrm{vg}$ of baa/vg is het grootst gedurende het eerste arbeidsongeschiktheidsjaar i.c de ziektewetperiode. Het effect van deze interacties is bepalend voor de instroom in de WAO of IP en draagt substantieel bij aan de kosten van het sociale verzekeringsstelsel. Om het handelen van vg'n en ba/vg'n te onderzoeken is gekozen voor een registratie van het handelen en de activiteiten van vg"n en ba/vg"n bij de begeleiding van arbeidsongeschikten vanaf de $2 \mathrm{e}$ tot en met de $9 \mathrm{e}$ arbeidsongeschiktheidsmaand: de periode warin de begeleiding het meest intensief is. Dit impliceert dat de begeleiding van kortdurende arbeidsongeschikten $(<$ 4 weken) en langdurig arbeidsongeschikten ( $>9$ maanden) buiten beschouwing blifft.

Vanuit de hiervoor beschreven omstandigheden en de vaststelling op grond van eerdere studies, dat er verschil is in handelen en effect, komt de vraag aan de orde in hoeverre het beleid van de $\mathrm{vg}$ en $\mathrm{ba} / \mathrm{vg}$ van invloed is op de verzuimduur. Deze probleemstelling wordt, zoals al bleek in paragraaf 1.6 in een viertal vragen uitgewerkt, te weten:

1. Welke activiteiten ontplooien vg'n en ba/vg'n in het kader van de controle en begeleiding? 
2. Zijn er verschillen in activiteiten en taakopvatting tussen deze twee groepen artsen?

3a. Zijn de verschillen in arbeidsongeschiktheidsduur afhankelijk van de taakopvattingen en activiteiten van de $\mathrm{kg}$ en $\mathrm{ba} / \mathrm{vg}$ ?

3b. Zijn de verschillen in ao-duur afhankelijk van de organisatorische context, waarbinnen de vg en ba/vg werkzaam zijn?

Het registreren van het handelen van de twee categorieẽn artsen geschiedt aan de hand van de begeleiding van patiënten, die arbeidsongeschikt zijn ten gevolge van ziekten behorend tot bepaalde diagnosegroepen: ziekten van het bewegingsstelsel, psychische ziekten, ziekten van de ademhalingswegen, ziekten van het hart- en vaatstelsel en ongevallen. De keuze voor deze diagnosecategorieën is bepaald op grond van hun bijdrage aan het ziekteverzuim in Nederland: rond de $60 \%$ van het ziekteverzuim valt onder de diagnosegroepen psychische ziekten, ziekten van het bewegingsstelsel en ongevallen (zie tabel 3.3). De diagnosegroepen: ziekten van het hart- en vaatstelsel en de ademhalingswegen, zijn mede opgenomen om aan te kunnen sluiten bij lopend onderzoek van de Rijksuniversiteit Limburg.

De overige diagnosegroepen hebben een zo lage frequentie van voorkomen, dat gelet op de omvang van de onderzoekspopulatie opname in dit onderzoek niet opportuun werd geacht.

De registratie van de door vg'n en ba/vg'n uitgevoerde activiteiten zullen naar verwachting een per categorie arts verschillende taakinvulling opleveren zowel wat betreft de omvang en aard van de begeleidingsactiviteiten alsook de verwachtingen ten aanzien van het effect van de begeleiding. De vraag is in hoeverre deze verschillen zijn terug te voeren op verschillen in taakopvattingen, ervaring en het vervullen van de functie van $v g$ of ba/vg.

Daarnaast kunnen verschillen ontstaan vanuit de organisatorische context, waarbinnen de arts werkzaam is, wat betreft de verschillende soorten uitvoeringsorganisaties, de beschikbare onderzoeksbegeleidingsmogelijkheden en de afstand tussen arts en bedrijf. Het effect van verschillen in de feitelijke vraag van een patiënt om begeleiding wordt niet onderzocht. Immers, het aanbod wordt sterk door de wetgeving en uitvoeringsorganisaties bepaald: de patiënt is verplicht zich te onderwerpen aan beoordeling en begeleiding om in aanmerking te komen voor de gewenste uitkering.

Vanuit verschillen in taakopvatting, handelen en organisatorische context zijn effecten op de ziekteduur, de werkhervatting en de instroom in de WAO en IP te verwachten. De demografische kenmerken van de werknemerspopulatie, die door de vg en ba/vg verzorgd worden, zullen als controlevariabelen beschouwd worden.

Het onderzoek naar de taakopvattingen neemt binnen dit onderzoek een bijzondere plaats in. Immers, niet eerder is onderzoek verricht naar takopvattingen van vg'n en ba/vg'n. In hoofdstuk 4 wordt het onderzoek naar de taakopvattingen beschreven en de verschillen in taakopvatting tussen vg en ba/vg (én ba'n) aangegeven. Dit hoofdstuk wordt besloten met de beschrijving van de onafhankelijke (verklarende) taakopvattings- 
variabelen, welke bij de analyse van de verschillen in handelen tussen $\mathrm{vg}$ en ba/vg (hoofdstuk 5) en het effect daarvan op de arbeidsongeschiktheidsduur gebruikt zullen worden.

In figuur 7 is de opbouw van het onderzoek schematisch weergegeven onder aanduiding van de hoofdstukken, waarin de betreffende onderdelen besproken zullen worden.

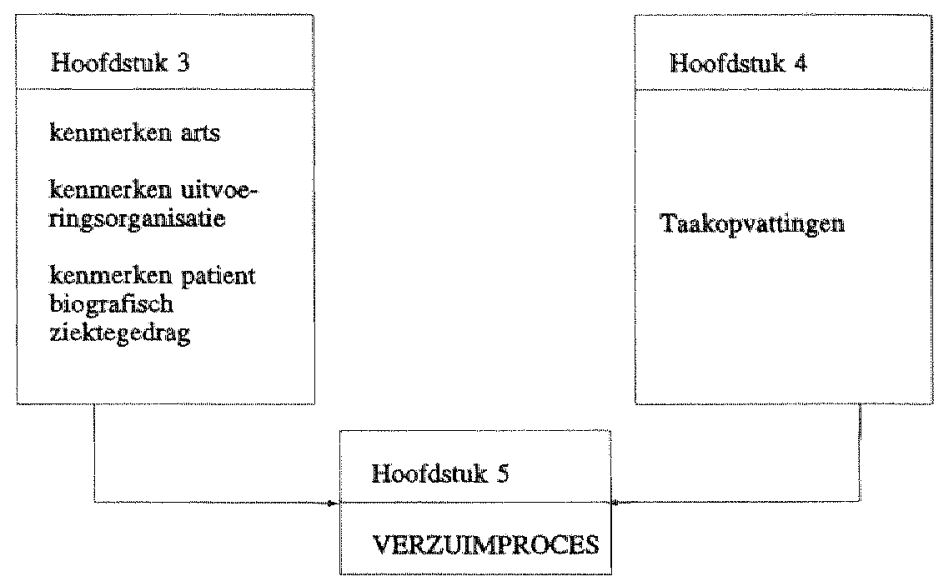

Figuur 7 Schematische weergave opbouw onderzoek 



\section{ONDERZOEKSOPZET}

Het onderzoek betreft in feite een tweetal te onderscheiden, niet te scheiden, deelonderzoeken: het onderzoek naar de taakopvattingen van artsen, in dit geval $\mathrm{vg}^{\mathrm{n}} \mathrm{n}$, ba/vg'n en ba'n, en het onderzoek naar het verzekeringsgeneeskundig handelen van vg'n en ba/vg'n.

In dit hoofdstuk worden achtereenvolgens beschreven:

in paragraaf 3.1: de samenstelling van de artsenpopulaties zowel wat betreft het onderzoek naar de taakopvatting als het verzekeringsgeneeskundig handelen;

in paragraaf 3.2: de samenstelling van de patièntenpopulaties, aan de hand waarvan het verzekeringsgeneeskundig handelen werd gemeten;

in paragraaf 3.3: de wijze van het verzamelen van gegevens ten behoeve van het onderzoek naar de taakopvattingen, en

in paragraaf 3.4: de wijze van het verzamelen van gegevens ten behoeve van het onderzoek naar het verzekeringsgeneeskundig handelen.

\subsection{De artsen}

Het onderzoeksgebied beperkt zich tot de regio Zuid-Limburg.

In het onderzoeksgebied zijn ten behoeve van de uitvoering van de ziektewet de volgende instellingen werkzaam:

1. Gemeenschappelijk Administratiekantoor, namens een 13-tal bedrijfsverenigingen (GAK)

2. De Bedrijfsvereniging voor de Bouwnijverheid (BV Bouw)

3. De Bedrijfswereniging voor de Gezondheid, Geestelijke en Maatschappelijke Belangen (BVG);

4. De Bedrijfsvereniging voor de Detailhandel, Ambachten en Huisvrouwen (DETAM);

5. De Bedrijfswereniging voor de Tabaksverwerkende en Agrarische Bedrijven (BV $T A B)$; ten tijde van het onderzoek waren dit nog twee afzonderlijke bedrijfsverenigingen.

6. De Bedrijfsvereniging voor het Bakkersbedrijf, en

7. De Bedrijfsvereniging voor het Slagers- en Vleeswarenbedrijf, de Groothandel in Vlees en de Pluimveeslachterijen "De Samenwerking".

In het onderzoeksgebied Zuid-Limburg zijn ten behoeve van de beoordeling en begeleiding van arbeidsongeschikte ambtenaren de volgende instanties werkzaam:

1. De Rijks Bedrijfsgezondheids- en Bedrijfsveiligheidsdienst (RBB, voorheen RGD);

2. De Bedrijfsgezondheidsdienst PTT (tijdens het onderzoek nog overheid; sedert 1 januari 1989 geprivatiseerd en vallend onder de ziektewet); 
3. De Bedrijfsgezondheidsdienst NS;

4. De Districtsgezondheidsdiensten te Geleen, Heerlen en Maastricht, en

5. De Bedrijfsgezondheidsdienst Zuidelijk Zuid-Limburg.

Deze instellingen ontlenen hun opdracht aan het Algemeen Rijksambtenarenreglement (ARAR) en voeren verzuimbegeleiding uit volgens de richtlijnen van het Ministerie van Binnenlandse Zaken.

Niet alle bovengenoemde instellingen nemen aan het onderzoek deel. De aan het onderzoek deelnemende instellingen zijn geselecteerd op grond van de volgende criteria:

1. De participerende instelling diende te beschikken over, $\mathrm{vg}^{\prime} \mathrm{n}$ of ba'n met een verzekeringsgeneeskundige taak;

2. Deze artsen dienden in ieder geval betrokken te zijn bij de begeleiding van arbeidsongeschikten gedurende het eerste jaar arbeidsongeschiktheid;

3. De instelling diende bereid te zijn tot deelname.

Met name op grond van het eerste criterium was voor een aantal instellingen deelname niet mogelijk: zij beschikten niet over $\mathrm{vg}^{\prime} \mathrm{n}$ of ba/vg'n. Veelal wordt de controle en begeleiding gedurende het ziektewetjaar verricht door plaatselijke huisartsen. Dit geldt voor de Bedrijfsvereniging voor de Tabakverwerkende Industrieën, de Bedrijfsvereniging voor het Bakkersbedrijf en de Bedrijfsvereniging voor het Slagers- en Vleeswarenbedrijf, de Groothandel in Vlees en de Pluimveeslachterijen "De Samenwerking". Tevens gold dit voor de Bedrijfsvereniging voor de Detailhandel, Ambachten en Huisvrouwen (DETAM), die ten tijde van de selectie van de artsen nog grotendeels gebruik maakte van huisartsen. Inmiddels maakt de DETAM in toenemende mate gebruik van vg'n.

De Bedrijfsvereniging voor de Gezondheid, Geestelijke en Maatschappelijke Belangen (BVG) neemt een bijzondere plaats in: zij maakte toentertijd gedurende de eerste drie maanden arbeidsongeschiktheid nog gebruik van huisartsen, waarna de begeleiding wordt overgedragen aan eigen vg' $\mathrm{n}$. Deze vg' $\mathrm{n}$ voeren gedurende de eerste drie maanden de supervisie over de huisartsen. Gelet op de te registreren begeleidingsperiode, vanaf de $4 \mathrm{e}$ tot de $8 \mathrm{e}$ week gerekend vanaf de eerste arbeidsongeschiktheidsdag, werd besloten de BVG in het onderzoek te betrekken.

Van de uitvoeringsorganisaties ten behoeve van ambtenaren zagen twee instellingen van deelname af vanwege het verwachte tijdsbeslag. Eén instelling was bereid tot medewerking, doch moest hiervan wegens ziekte van de arts alsnog van afzien.

De vg'n en ba/vg'n nemen deel aan het onderzoek naar taakopvatting én het verzekeringsgeneeskundig handelen. Ten behoeve van het onderzoek naar taakopvattingen onder ba'n is gebruik gemaakt van de Bedrijfsgezondheidsdienst Zuidelijk Zuid-Limburg. 
De samenstelling van de onderzokspopulaties artsen op grond van de bovengenoemde criteria is weergegeven in de tabellen 3.1 (taakopvattingen) en 3.2 (verzekeringsgeneeskundig handelen).

Tabel 3.1 Samenstelling onderzoekspopulatie artsen naar categorie arts ten behoeve wan thet onderwoek naar taakopwattingen

Verklaring codes categorie arts:

$$
\begin{array}{ll}
\mathrm{vg} & =\text { verzekeringsgeneeskundige } \\
\mathrm{ba} / \mathrm{vg} & =\text { bedrijfsarts/verzekeringsgeneeskundige } \\
\mathrm{ba} & =\text { bedrijfsarts }
\end{array}
$$

\begin{tabular}{|c|c|c|}
\hline categorie arts & uitvoeringsorganisatie $\$ V$ & anntal artsen \\
\hline vg & $\begin{array}{l}\text { GAK } \\
\text { SFB }\end{array}$ & $\begin{array}{c}16 \\
5\end{array}$ \\
\hline subtotalal vg & & 21 \\
\hline$b a / v g$ & $\begin{array}{c}\text { RBB, DGD } \\
\text { BGD/PTT, } \\
\text { BGD-DSM (superaker) }\end{array}$ & 7 \\
\hline subtotaal ba/vg & & 14 \\
\hline bal & BGD Zuidelijk Zuid-Limburg & 16 \\
\hline Totaal artsen & & 51 \\
\hline
\end{tabular}

Tabel 3.2 Samenstelling onderzoekspopulatie artsen naar categorie arts ten behoeve van het onderzoek naar (het effect van) het verzekeringsgeneeskundig handelen

Verklaring codes categorie arts:

$$
\begin{array}{ll}
\mathrm{vg} & =\text { verzekeringsgeneeskundige } \\
\mathrm{ba} / \mathrm{vg} & =\text { bedrijfsarts/verzekeringsgeneeskundige } \\
\mathrm{ba} & =\text { bedrijfsarts }
\end{array}
$$

\begin{tabular}{l|c|c|c|}
\hline soort arts & organisatie SV & aantal artsen & aantal patiënten \\
\hline vg & GAR & 16 & 210 \\
& SFB, BVG & 5 & 75 \\
subtot. $v g$ & $21 *$ & 285 \\
ba/vg & RBB, DGD, & 7 & 105 \\
& DSM, PTT & 7 & 105 \\
subtot. ba/vg & & 14 & 210 \\
\hline Total & & 35 & 495 \\
\hline
\end{tabular}

* onder de vgn'n bevinden zich een 4-tal part-timers; per full-time vg of per 2 part-timers wordt het verzekeringsgeneeskundig handelen geregistreerd aan de hand van de begeleiding van 15 patienten.

\subsection{De patiënten}

Het onderzoek heeft tot doel inzicht te krijgen in het handelen en het effect van het handelen van $\mathrm{vg}^{\prime} \mathrm{n}$ en ba/kg'n op het ziekteverzuim van arbeidsongeschikte werkne- 
mers en ambtenaren.

De wijze van beoordelling en begeleiding van patiënten en het effect daarvan werd geregistreerd aan de hand van de begeleiding van minimaal 15 patiënten per arts. Hierbij wordt uitgegaan van een full-time dienstverband van de arts.

Om er verzekerd van te zijn dat ten behoewe van het meten van het handelen van de $\mathrm{vg}$ 'n en tra/vg'n voldoende in begeleiding zijnde patiënten voorhanden zouden zijn, werd retrospectief onderzoek verricht naar het verloop van de verzuimduur in een representatieve patiëntenpopulatie. Tevens is nagegaan vanaf welke arbeidsongeschiktheidsduur er sprake is van verzekeringsgeneeskundige begeleiding; ook het moment waarop de begeleiding in de regel wordt beëindigd is onderzocht.

Een ziekmelding leidt niet in alle gevallen tot een verzekeringsgeneeskundige begeleiding. Vaak wordt de patiènt in eerste instantie schriftelijk (via een informatiebriefje) benaderd of bezocht door een leek (bijvoorbeeld rapporteur ziektewet). Op grond van de aldus verkregen informatie wordt een eerste verzekeringsgeneeskundige beoordeling gepland, tenzij de patiënt inmiddels het werk reeds hervat heeft. Om deze reden ligt het moment van start van de verzekeringsgeneeskundige begeleiding vaak weken tot maanden nà de le arbeidsongeschiktheidsdag. Ook het moment waarop de verzekeringsgeneeskundige begeleiding wordt beëindigd, vindt op grond van de geldende regelgeving bij de uitvoeringsorganisaties op verschillende tijdstippen plaats.

De populatie patiënten, waarvan de begeleiding in kaart wordt gebracht, omvat vrijwel alle sectoren van het bedrijfsleven in Nederland. In die zin is er een grote overeenkomst met de door het GAK verzorgde verzekerdenpopulatie. Dit maakt het mogelijk om op grond van de arbeidsongeschiktheidsduur van de GAK-patiëntenpopulatie inzicht te krijgen in de perioden, waarin sprake is van verzekeringsgeneeskundige begeleiding.

Figuur 8 geeft een overzicht van de ziekmeldingen verdeeld over de duurklassen van de GAK-patiëntenpopulatie in 1989. Tevens is voor de volledigheid het percentage van het verzuimvolume (aantal verzuimdagen) van de betreffende duurklasse weergegeven. In de eerste maand treedt een zeer sterke daling op van het aantal arbeidsongeschikten: na 1 maand heeft $80 \%$ van de arbeidsongeschikten het werk hervat, veelal zonder dat er sprake is geweest van een verzekeringsgeneeskundige interventie. Bij 3 maanden arbeidsongeschiktheid blijkt nog slechts $4,5 \%$ arbeidsongeschikt te zijn. Uiteindelijk blijft $1,3 \%$ van de arbeidsongeschikten 1 jaar of langer arbeidsongeschikt.

In gesprekken met de aan het onderzoek deelnemende instellingen werd de begeleidingsmethodiek in kaart gebracht en het moment vastgesteld, waarop de verzekeringsgeneeskundige beoordeling en begeleiding feitelijk start. Verschillende instellingen maken gebruik van leken of huisartsen gedurende de eerste weken tot maanden van arbeidsongeschiktheid; datarnatast hanteren verschillende instellingen gedurende de eerste weken administratieve procedures, waarbij de $v g$ 'n en ba/vg'n niet ingeschakeld worden. Bovendien werd door sommige ba/vg'n een in de tijd vroegtijdige spreekuurbeoordeling niet zinnig gevonden en derhalve niet uitgevoerd. 


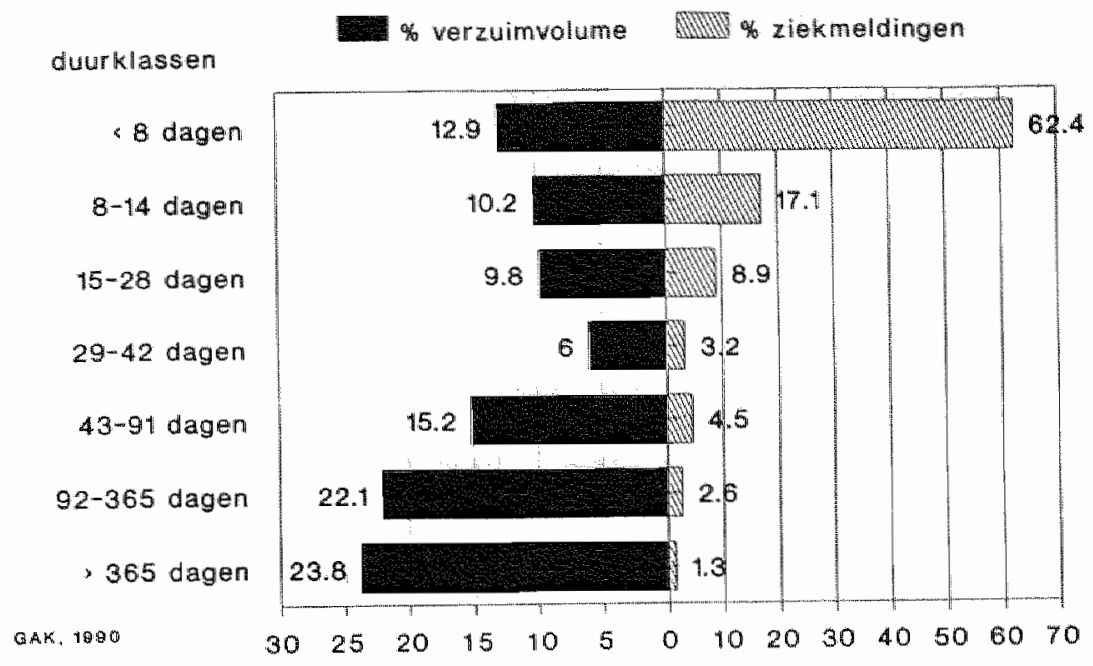

Figuur 8 Ziekmeldingen en verzuimwolume naar verzuimduurklasse 1989, GAK-BV'n omslagleden

Het moment waarop de verzekeringsgeneeskundige beoordeling en begeleiding start ligt in de regel tussen 2 en 6 weken, gerekend vanaf de eerste arbeidsongeschiktheidsdag. De beëindiging van de verzekeringsgeneeskundige begeleiding ligt, mede op grond van de regelgeving, rond de $9 \mathrm{e}$ arbeidsongeschiktheidsmaand.

Rekening houdend met het verloop van de verzuimduur in de tijd én het moment, waarop de verzekeringsgeneeskundige beoordelings- en begeleidingsactiviteiten ontplooit, is gekozen voor het registreren van het handelen van de vg en de ba/vg ingaande de $5 \mathrm{e}$ arbeidsongeschiktheidsweek tot de $9 \mathrm{e}$ arbeidsongeschiktheidsmaand.

Als startmoment van de registratie van activiteiten van vg'n en ba/vg'n is gekozen voor een arbeidsongeschiktheidsduur op de selectiedag van minimaal 4 en maximaal 8 weken.

Op grond van de samenwerkingsafspraken tussen de bedrijfsverenigingen en de Gemeenschappelijk Medische Dienst is voorzien in een overdracht van de begeleiding van de vg van de bedrijfsvereniging naar de vg van de GMD uiterlijk bij een arbeidsongeschiktheidsduur van 9 maanden. Dit stelt de GMD in staat tijdig de bedrijfsvereniging te adviseren met betrekking tot het toekennen van een uitkering krachtens de WAO ingaande de $53 \mathrm{e}$ arbeidsongeschiktheidsweek.

Daarnaast wordt van genoemde overdracht een reïntegratiebevorderend effect verwacht. Deze vorm van overdracht betekent dat de begeleiding door de vg'n van de bedrijfsvereniging in de regel beëindigd wordt op of rond de $9 \mathrm{e}$ arbeidsongeschiktheidsmaand.

Bij de uitvoering van de begeleiding van arbeidsongeschikte ambtenaren gelden derge- 
lijke samenwerkingsafspraken niet; het moment wan overdracht van de begeleiding naar het $A B P$ wordt in hoge mate bepaald door de vaststelling van blijvende arbeidsongeschiktheid en het niet kunnen realiseren van een herplaatsing.

De begeleiding van ambtenaren door de ba/vg kan derhalve ook na de 9e maand voortgang vinden.

Op grond van bovenstaande constateringen is besloten de registratie van de activiteiten, de oordeelsvorming en verwachtingen van de vg" $\mathrm{en}$ ba/vg'n te registreren gedurende maximaal 8 maanden.

Bij de bepaling van de omvang van de patiëntenpopulatie is tevens uitgegaan van de vier meest voorkomende diagnosegroepen: psychische ziekten, ziekten van het bewegingsstelsel, ziekten van het hart- en vaatstelsel en ziekten van de ademhalingswegen. Tabel 3.3 toont het voorkomen van diagnosegroepen in de GAK-ziektewetpopulatie; tabel 3.4 toont de verdeling over diagnosegroepen van AAW/WAO gevallen.

Tabel 3.3 Procentuele verdeling toegekende diagnosecodes ziektewet, alo-duur $\geq 3$ maanden (GAK, 1987)

\begin{tabular}{llr||llr}
0 & Diagnose onbekend & 10.7 & $\mathrm{XX}$ & Spijsvertering & 3.9 \\
I & Infecties & 1.2 & $\mathrm{X}$ & Urogenitiall & 1.9 \\
II & Nieuwvormingen & 2.0 & XI & Zwangerschap & 3.4 \\
III & Stofwisseling & 0.7 & XII & Huid & 0.9 \\
IV & Bloed & 0.2 & XII & Bewegingstelsel & 28.0 \\
V & Psyche & 24.0 & XIV & Congenitaal & 0.2 \\
VI & Zenuwstelsel & 3.0 & XVI & Symptomen & 1.7 \\
VII & Hart/vuat & 6.7 & XVII & Ongevallen & 9.0 \\
VIII & Ademhaling & 2.5 & & & \\
\hline
\end{tabular}

Op grond van de tabellen 3.3 en 3.4 kunnen we concluderen dat de verschillen in verdeling over de diagnosegroepen tussen de ziektewet en AAW/WAO nagenoeg gelijk is. Het aandeel van de diagnosegroepen $V$ (psyche) en XIII (bewegingsstelsel) in de AAW/WAO-populatie is iets groter dan in de ziektewetpopulatie.

Door het betrekken in het onderzoek van de diagnosegroepen V (psyche), VII (hart/ vaat), VIII (ademhaling) XIII (bewegingsstelsel) en XVII (ongevallen) wordt $80 \%$ van de totale populatie in het onderzoek betrokken.

Samengevat is het selecteren van patiënten in het kader van het onderzoek geschiedt aan de hand van een drietal selectiecriteria:

1. leeftijd: $20-40$ jaar;

2. arbeidsongeschiktheidsduur op selectiedatum minimaal 4 en maximaal 8 weken;

3. diagnosegroep: psychische afwijkingen, hart- en vaatziekten, longziekten en ziekten van de bewegingsorganen. 
Tabel 3.4 Procentuele perdeling van het total amidal opgekomen AAW/WAO-gevallen maar oortaak arbeidsongeschiktheild $(S V R, 1988)$

\begin{tabular}{|c|c|c|c|c|c|c|c|c|}
\hline & & 1980 & 1981 & 1982 & 1983 & 1984 & 1985 & 1986 \\
\hline I & Infecties & 0.6 & 0.5 & 5.2 & 1.1 & 1.1 & 1.2 & 2.2 \\
\hline II & Nieuwvormingen & 3.2 & 3.6 & 5.2 & 4.0 & 4.0 & 3.7 & 3.4 \\
\hline III & Stofwisseling & 1.0 & 1.1 & 1.1 & 1.2 & 1.3 & 1.2 & 1.2 \\
\hline IV & Bloed & 0.2 & 0.2 & 0.2 & 0.2 & 0.2 & 0.2 & 0.2 \\
\hline v & Psyche & 26.3 & 25.9 & 26.9 & 29.4 & 30.7 & 30.7 & 29.5 \\
\hline VI & Zenuwstelsel & 4.8 & 5.0 & 4.9 & 5.1 & 4.8 & 4.6 & 4.3 \\
\hline VII & Hart/vat & 14.8 & 14.7 & 13.0 & 12.5 & 12.2 & 11.0 & 10.8 \\
\hline VIII & Ademhaling & 4.5 & 4.1 & 3.3 & 3.5 & 3.2 & 3.0 & 2.9 \\
\hline IX & Spijswertering & 3.2 & 3.1 & 2.6 & 2.6 & 2.5 & 2,4 & 2.4 \\
\hline $\mathrm{X}$ & Urogenitaal & 1.4 & 1.4 & 1.2 & 1.4 & 1.3 & 1.3 & 1.1 \\
\hline $\mathrm{XI}$ & Zwangerschap & 0.2 & 0.2 & 0.2 & 0.3 & 0.3 & 0.4 & 0.4 \\
\hline $\mathrm{XI}$ & Huid & 0.9 & 1.0 & 0.7 & 0.7 & 0.8 & 0.8 & 0.5 \\
\hline XIII & Bewegingsstelsel & 29.0 & 29.7 & 28.2 & 30.3 & 29.8 & 32.1 & 33.2 \\
\hline XIV & Congenitaal & 0.8 & 0.8 & 0.8 & 1.0 & 0.8 & 0.7 & 0.7 \\
\hline XVI & Symptomen & 3.6 & 3.2 & 2.0 & 1.9 & 2.0 & 1.9 & 2.0 \\
\hline \multirow[t]{2}{*}{ XVII } & Ongevallen & 5.5 & 5.5 & 4.5 & 4.8 & 5.0 & 5.1 & 5.0 \\
\hline & & 100.0 & 100.0 & 100,0 & 100.0 & 100.0 & 100.0 & 100.0 \\
\hline
\end{tabular}

De selectie op de criteria leeftijd en arbeidsongeschiktheidsduur werd uitgevoerd door de administratie van de betreffende instelling op de door de onderzoekers aangegeven selectiedag.

$\mathrm{Na}$ ontvangst van de medische gegevens werd door de onderzoekers vervolgens een selectie op grond van de diagnose(groep) uitgevoerd.

\subsubsection{Selectie door instellingen}

On het handelen van $\mathrm{vg}^{\prime} \mathrm{n}$ en ba/vg'n te meten en verschillen in handelen in kaart te brengen is het noodzakelijk om over vergelijkbare patiëntenpopulaties per categorie arts te beschikken. Deze patiëntenpopulaties behoeven geen afspiegeling te zijn van de werkelijke samenstelling van de door deze artsen verzorgde populaties. De bovenbeschreven selectieprocedure, waaraan de selectie op ziektediagnose wordt toegevoegd, leidt tot, op deze aspecten per categorie arts, vergelijkbare populaties.

Ten behoeve van de uniformering van deze selectie werden alle administraties van de deelnemende instellingen door de onderzoekers ruim voor de start van het onderzoek bezocht. Hierbij werd de werkwijze van de betreffende administratie in kaart gebracht en de selectiemethode geïnstrueerd.

In de praktijk blijken er wat het oproepen van patiënten betreft een drietal administratieve methoden gebruikt te worden:

1. het oproepen geschiedt op een door de arts vastgestelde dag in alfabetische volgorde al of niet op een vastgestelde tijd; 
2. het oproepen geschiedt op een door de ants vastgestelde dag in volgorde van binnenkomst van de patient.

3. Er is geen sprake van een oproep op een waste dag en/of op een vast tijdstip; de patiênt wordt schriftelijk of mondeling (door een lekencontroleur of door de arts ujdens wen eerder spreekuurbezoek) verzocht in een bepaalde periode of rond een bepald tijdstip zonodig het spreekuur te bezoeken.

Meestal is er sprake van methode 1 of 2 , beide in combinatie met methode 3 . Tussenwomen, waarbij sprake is van de methoden 1 en 2 in combinatie met methode 3 komen voor.

De selectie van patienten ten behoeve van het onderzoek is op grond van door de onderzoekers vastgestelde regels uitgevoerd door de deelnemende instellingen en uitvoeringsorganisaties.

Als uitgangspunt bij de selectie van patiënten geldt dat iedere patiënt een even grote selectiekans behoort te hebben. Om dit te bereiken werd aan de administratie van de aan het onderzoek deelnemende instellingen of uitvoeringsorganisaties een zogenaamde selectielijst per deelnemende arts verstrekt. Op deze selectielijst per deelnemende arts is naast de datum van selectie tevens aangegeven de hoeveelste patiènt, in volgorde van aanmelden, aan het onderzoek zal deelnemen. Tevens zijn op deze selectielijst per selectiedag de criteria leeftijd (geboortejaar) en verzuimduur (selectiedatum minus datum le arbeidsongeschiktheidsdag) aangegeven.

Tevens konden op deze selectielijst algemene persoonsgegevens van de geselecteerde patiènt te vermelden. Deze gegevens waren uitsluitend bekend bij de administratie van de instellingen en dienden ter bewaking van het verloop van de begeleiding van de aan het onderzoek deelnemende patiënten.

Uitgaande van het gemiddeld aantal per dag op het spreekuur ontvangen patiënten werd geselecteerd op de le tot en met maximal de $15 \mathrm{e}$ patiënt.

\subsubsection{Uitvoering van het onderzoek door de instellingen}

In de weken direct woorafgaande aan de start van he onderzoek werden alle instellingen nogmaals bezocht, waabij de selectieprocedure gedetailleerd werd doorgenomen en beoordeeld op halbaarheid binnen de betreffende administratie; tevens ontving elke met de selectic belaste medewerk(st)er een persoonlike instructie; iedere medewark (st)er ontving tevens een schriftelijke instructie, waarin de selectieprocedure beschreven stond en aangegeven werd hoe te handelen in een aantal voorzienbare prakajksituaties.

De bewaking door de onderzokers van het selectieproces geschiedde aan de hand van de door de arts bij het le bezock in te vullen vragenlijst, bevattende vragen over de persoon en de voorliggende arbeidsongeschiktheidsperiode waaronder onder andere de 
eerste arbeidsongeschiktheidsdag en contacten met de curatieve sector en werkgever. De bewaking van de registratie van het verzekeringsgeneeskundig handelen geschiedde door middel van een registratie van ontvangen vragenlijsten per patiënt. Het niet tijdig ontvangen van deze wragenlijsten leidde tot overleg en corrigerende acties naar de instellingen en uitvoeringsorganisaties.

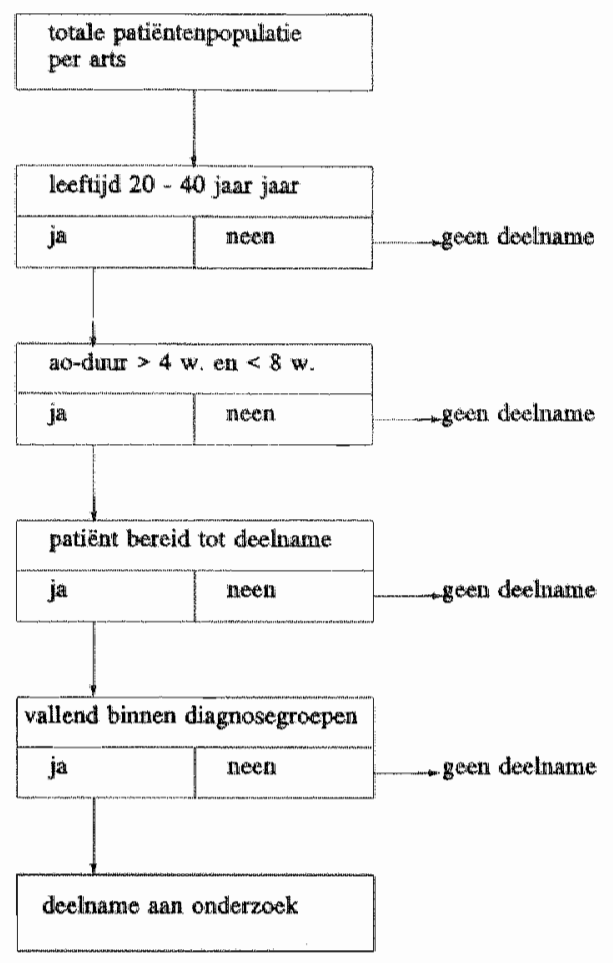

Figuur 9 Sellectieprocedure onderzoekspopulatie patienten

Gelet op de verschillende werkwijzen en de somtijds wat beperkte bewaking van het administratieve proces door de instellingen en uitwoeringsorganisaties, is het praktisch niet doenlijk gebleken zicht te houden op het aantal patiënten, dat deelname weigerde, en het aantal patiënten, dat, hoewel geselecteerd op datum en volgorde, niet voldeed aan de selectiecriteria leeftijd en arbeidsongeschiktheidsduur. Uit periodiek overleg bleek overigens, dat het niet willen deelnemen aan het onderzoek slechts sporadisch voorkwam. In figuur 9 zijn de selectieregels weergegeven. 


\subsection{Gegevensverzamelingen}

\subsubsection{Kenmerken van artsen}

De kenmerken van de aan het onderzoek deelnemende $\mathrm{vg}^{\prime} \mathrm{n}, \mathrm{ba} / \mathrm{wg}^{3} \mathrm{n}$ en ba $\mathrm{n}$ zijn met behulp van interviews aan de hand wan een standaardvragenlijst in kaart gebracht.

Deze artsenvragenlijst (de zogenaamde A-lijst) bevat vragen over de volgende onderwerpen:

1. persoonsgegevens van de $v g$ en ba/vg;

2. opleidings- en werkgegevens;

3. de huidige functie, het huidige werk en de werkwijze;

4. het door de arts gehanteerde controle- en begeleidingssysteem

5. de ter beschikking staande faciliteiten en hulpmiddelen

6. de taakopvattingen van de individuele $\mathrm{vg}$ of $\mathrm{ba} / \mathrm{vg}$.

\subsubsection{Taakopvattingen van artsen}

Ten aanzien van het meten van taakopvattingen van artsen, in het bijzonder vg'n, ba/vg'n en ba'n, is nauwelijks eerder onderzoek bekend. Er kon dan ook niet teruggegrepen worden naar een bewezen betrouwbaar meetinstrument. Dit meetinstrument diende derhalve ontwikkeld te worden, waarbij gebruik is gemaakt van het onderzoek naar taakopvattingen van huisartsen (Boots, 1983). Deze en andere onderzoeken naar takopvattingen richten zich met name op de mate van "speelruimte", de feedback en andere aspecten van de takinhoud.

Dit onderzoek echter richt zich specifiek op de opvattingen over de meest gewenste taakinhoud, taakgerichtheid en taakomvang.

Een extra handicap is, dat de taken van de $\mathrm{vg}$ 'n en ba/vg'n minder duidelijk zijn dan gemeenlijk wordt verondersteld. Er blijken grote accentverschillen in de taken te bestaan (Winter, 1984; Epker, 1986) Zo rekenen sommige artsen het vaststellen van arbeidsongeschiktheid oftewel controle niet tot hun taak; het ziekmelden behoort immers tot de verantwoordelijkheid van de werknemer; een veel gehoorde mening van ba/vg' $n$. Ook bimen de kring van de $\mathrm{vg}$ 'n bleken verschillen te bestaan in de interpretatie van door de bedrijfsvereniging gegeven opdracht: sommigen bleken sterk controle gericht, anderen meenden dat begeleiding naar een reïntegratie de belangrijkste taak was. Een preventieve taak, gericht op het voorkomen van ziekteverzuim bleek niet door iedere arts onderschreven te worden.

Bij de samenstelling van de vragenlijst taakopvattingen (bijlage 3) is wegens het ontbreken van consensus over de taken bij de betrokken artsen uitgegaan van de taken zoals die voortuloeien uit de ziektewet en de interpretatie van deze taken door de bedrijfswerenigingen. 
In paragraaf 4.2.1 wordt nader ingegaan op de inrichting van de taakopwattingen-vragenlijst. De bruikbaarheid van de vragenlijst werd in een pilot-study in de praktijk getoetst. Aan deze pilot-study namen vg'n en ba/vg'n deel uit het westelijk deel van de provincie Noord-Brabant. Deze vg'n en ba/vg'n behoren niet tot de eigenlijke artsenonderzoekspopulatie. Na enige redactionele bijstellingen ontstond de in het onderzoek gebruikte vragenlijst.

De vragen met betrekking tot de taakopvattingen zijn door de vg'n, ba/vg'n en ba'n op de dag van het interview ingevuld; het was niet mogelijk over de taakopvattingenvragen onderling overleg te plegen dan wel vragen te stellen aan de onderzoekers. Deze vragenlijsten werden direct na inwulling ingeleverd bij de onderzoekers.

\subsubsection{Het verzekeringsgeneeskundig tandelen}

Met betrekking tot het registreren van het verzekeringsgeneeskundig handelen zijn twee methoden van onderzoek mogelijk: retrospectief of prospectief. Retrospectief betekent dat het medisch dossier van in begeleiding zijnde of in begeleiding geweest zijnde patiënten als bron van informatie over het handelen van de arts zou gelden.

Gelet op de inhoudelijke kwaliteit en kwantiteit van de in de medisch dossiers opgeslagen informatie en de gedetailleerde vraagstellingen in het kader van dit onderzoek, bleek retrospectief onderzoek geen antwoord te kunnen geven op de gestelde vragen. Om deze reden is gekozen voor een prospectief onderzoek, waarbij het nadeel van een grotere belasting van de aan het onderzoek deelnemende artsen op de koop toe genomen moest worden.

Het handelen van vg'n en ba/ $/ \mathrm{vg}^{\prime} \mathrm{n}$ is in kaart gebracht met behulp van de verzekeringsgeneeskundige vragenlijst (de zogenaamde $\mathrm{vg}-\mathrm{lijst}$ ), die wragen bevat over de oordeelsvorming en begeleiding, namelijk:

1. de daturn van beoordeling;

2. de door de $\mathrm{vg}$ of $\mathrm{ba} / \mathrm{vg}$ gestelde hoofddiagnose (de diagnose die huidige arbeidsongeschiktheid veroorzaakt) en nevendiagnose.

3. het verzekeringsgeneeskundige begeleidingsplan;

4. indien van toepassing: de aard en reden van inschakeling van medisch specialist, werkgever of ba;

5. de verzekeringsgeneeskundige conclusie;

6. de datum van werkhervatting of herbeoordeling;

7. de prognose met betrekking tot de verwachte eindsituatie en de datum waarop die eindsituatie word verwacht;

8. de contacten met de huisarts en de door de huisarts ingestelde therapie, en

9. de contacten met de specialist en de door de specialist ingestelde therapie.

Deze vg-vragenlijst diende door de $\mathrm{vg}$ of ba/vg na iedere beoordeling te worden ingevuld. Deze vragenlijst vormt de basis van dat deel van het onderzoek, dat het registreren wan het handelen van de $\mathrm{Fg}$ " $n$ en ba/vg' $n$ betreft. 
In veel gevallen wordt de begeleiding beëindigd zonder dat de $\mathrm{vg}$ of ba/vg het initiatief hiertoe heeft genomen. Immers, de patiënt dient het werk te hervatten, zodra hij/zij zich daartoe in staat voelt. Daarnaast kan de begeleiding om andere redenen gestaakt worden: bijwoorbeeld wegens verhuizing of overlijden van de patiënt; of wat betreft dit onderzoek wegens overschrijding van de maximale registratieduur. In deze situaties werd door de administratie van de aan het onderzoek deelnemende instellingen de eindlijst (de zogenaamde E-lijst) ingevuld. Deze eindlijst bevat vragen over:

1. de laatste arbeidsongeschiktheidsdag/datum van beëindiging van de registratie;

2. de redlen van beëindiging van de registratie.

\subsubsection{Kenmerken van patiènten}

Verschillen in handelen tussen vg'n dan wel ba/vg'n kunnen hun verklaring vinden in verschillen in patiëntenpopulatie. Om beider handelen te kunnen vergelijken moeten de variabelen, die invloed hebben op dit handelen, zoveel mogelijk uitgeschakeld worden. Tevens zal het handelen van de curatieve artsen invloed kunnen hebben op het handelen van de $\mathrm{vg}$ of $\mathrm{ba} / \mathrm{vg}$.

De vragenlijst patiënten bestaat dan ook uit twee delen:

1. een door de vg of ba in te vullen patiënt-arts-vragenlijst (de zogenaamde B1-lijst), bevattende vragen over globale persoonsgegevens van de patiënt, de eerste arbeidsongeschiktheidsdag en de tot de selectiedag onderhouden contacten met medewerkers van de uitvoerende instelling, curatieve sector en ba.

2. een door de patiënt in te vullen vragenlijst. Nadat de $\mathrm{vg}$ of ba/vg de B1-lijst-gegevens genoteerd had, werd de patiënt-vragenlijst (de zogenaamde B2-lijst) met instructie aan de patiënt uitgereikt met het verzoek deze na het spreekuur (of eventueel thuis) in te vullen en in te zenden met behulp van de bijsloten antwoordenveloppe aan de Rijksuniversiteit Limburg. De $\mathrm{vg}$ of ba/vg had geen inzage in en is niet geïnformeerd over de antwoorden van de patiënt.

De door de patiënt in te vullen patiënt-vragenlijst (B2) bevat vragen over:

1. persoon en levensomstandigheden van de patiënt;

2. de taalbeheersing van de patiënt;

3. de huidige arbeicl en de door de patiënt als hinderlijk ervaren factoren in deze arbeid;

4. het huidige dienstverband en eventuele nevenwerkzaamheden;

5. het arbeidsverleden;

6. de ziekte, die oorzaak is van de huidige arbeidsongeschiktheid, en de behandelingscontacten die nu en in het verleden in verband met deze ziekte zijn geweest, en

7. de contacten, die de patiënt in verband met zijn huidige arbeidsongeschiktheid met de werkgever heeft gehad. 


\subsection{Inleiding}

Vg'n en ba/vg'n zijn veelal werkzaam ten behoeve van de uitvoering van dezelfde soort wetgeving. Behalve wettelijke verschillen zoals ten aanzien van ziekengelduitkering of loondoorbetaling bij arbeidsongeschiktheid of sanctiebepalingen, hebben ook verschillen tussen de uitvoeringsorganisaties invloed op de taken van de $\mathrm{vg}$ en ba/vg. Uitvoeringsorganisaties verschillen onder andere in verzorgde werknemerspopulatie en in inzicht in het ontstaan, het voortduren en in het beperken van ziekteverzuim. Laatstgenoemde verschil uit zich onder meer in de wijze van wetsuitvoering, bijvoorbeeld meer of minder op controle of preventie gericht. De wijze van uitvoering van de wetten door de verschillende instellingen en uitvoeringsorganisaties is, naar verwacht mag worden, van invloed op de wijze van werken van de vg en ba/vg en op beider taakopvatting.

Het antwoord op de vraag of er verschillen in takopvatting bestaan en zo ja, welke deze verschillen zijn, is om twee redenen van belang.

De eerste reden is louter nieuwsgierigheid. De Winter (1984) en Plomp (1985) hebben onderzoek gedaan naar taakopvattingen van ba'n. Niet eerder echter is er vergelijkend onderzoek gedaan naar taakopvattingen van vg'n, ba/vg'n en ba'n.

Op basis van verschillen in specialisatie en taken in relatie met de verzorgde populatie is het aannemelijk te veronderstellen dat er verschillem in takopvatting kunnen bestaan.

De tweede reden ontspruit direct uit de vraagstelling van dit onderzoek. Indien er verschillen in begeleiding van patiënten zijn, in hoeverre kunnen verschillen in taakopvatting hieraan ten grondslag liggen? In deze zin kunnen taakopvattingen beschouwd worden als verklarende variabelen voor waargenomen verschillen in het handelen van $v g$ 'n en ba/vg'n. De ba pur sang valt hier dus buiten, omdat deze geen verzekeringsgeneeskundige taken heeft en op dit punt onvergelijkbaar is. In hoofdstuk 5, waarin verschillen in handelen beschreven en waar mogelijk verklaard zullen worden, wordt hier nader op ingegaan.

Allereerst echter zullen de takopvattingen van de $\mathrm{vg}$, de ba/vg en ba bepaald worden. Vervolgens zullen de betrokken artsen ten opzichte van elkaar gepositioneerd worden wat betreft hun opvattingen over wel omschreven en van elkaar te onderscheiden taakaspecten, zoals de taakomvang, de taakgerichtheid en de inhoud van de taak. 


\subsection{Vragenlijsten}

\subsubsection{Het concipiëren van taakinhoudelijke variabelen: een modelbeschrijving}

Als uitgangspunt voor de maken van de vragenlijst taakopvattingen is gekozen voor het taakopvattingenmodel, zoals ontwikkeld en gehanteerd door Boots en Van Zutphen (1981) ten behoeve van de meting van taakopvattingen van huisartsen. Dit taakopvattingenmodel, dat zijn bruikbaarheid heeft bewezen voor huisartsen, gaat uit van een drietal takaspecten: de taakomvang, de taakgerichtheid en de taakinhoud. De vragenlijst voor de vg" $n$ en ba/vg' $n$ werd volgens deze aspecten ingericht, waarbij specifieke taakaspecten van de huisarts vervangen en aangevuld werden met specifieke taakaspecten van de vg.

Mede naar aanleiding van de sterke groei wan het aantal WAO-uitkeringsgerechigden verrichtte het Gemeenschappelijk Administratiekantoor onderzock naar de taakuitoefening door $\mathrm{vg}^{\mathrm{x}} \mathrm{n}$, resulterend in het rapport "Verzekeringsgeneeskundigen over hun werk $^{*}$ (GAK, 1986). Eén van de vraagstellingen betrof de vraag hoe vg'ñ zèlf tegen hun werk aankijken. Geconstateerd werd dat $\mathrm{vg}^{\prime} \mathrm{n}$ te onderscheiden zijn op basis van hun visie ten aanzien van controle en begeleiding en ten aanzien van hun belangstelling voor kortdurend en langdurend verzuim. Helaas bleef het onderzoek beperkt tot het registreren van vigerende opvattingen als zodanig onder vg'n.

Dit onderzoek strekt zich ook uit tot de vraag, wat de invloed van een taakopvatting op de uiteindelijke ao-duur is. Ten behoeve hiervan moest beschikt kunnen worden over taakopvattingsvariabelen, die voor de met verzekeringsgeneeskundige taken belaste artsen geldigheid bezaten. Met name die taakaspecten, waarover binnen de beroepsgroep discussies gevoerd werden, werden in de vragenlijst opgenomen. Tevens zijn vragen opgenomen om een onderscheid te maken tussen taakgerichtheid (het hanteren van formele procedures) en relatiegerichtheid (patiënt, bedrijf, curatieve sector).

De vragenlijst taakopvatting werd conform bovengenoemde 3 taak-aspecten als volgt ingericht:

* vragen met betrekking tot de taakomvang, gaande van alleen somatische diagnostiek via psychosociale diagnostiek naar begeleiding, reïntegratie en preventie.

* vragen met betrekking tot de taakgerichiheid, gaande van repressief (oneigenlijk gebruik voorkomend) tot het geven van ruimte voor eigen verantwoordelijkheid van de patiënt.

* vragen met betrekking tot de taakinhoud: het in de oordeelsvorming en het te voeren beleid willen betrekken van de anamnestische en fysisch-diagnostische gegevens $\mathrm{t} / \mathrm{m}$ gegevens over de bedrijfsorganisatie, de werkverhoudingen, de situatie op de werkplek het gedrag van de patiënt etc. 
Deze drie vragenclusters bestaan uit stellingen en uitspraken, waarop de respondent moet scoren op een 5-puntsschaal van eens (1) tot oneens (5). De stellingen zijn zowel in bevestigende als ontkennende vorm gegeven. In de vragenlijst betreffende taakopvattingen zijn de vragen niet geclusterd en in willekeurige volgorde opgenomen. Bijlage 3 bevat een overzicht van de taakopvattingenvragen.

Bij de analyse van de onderzoeksgegevens werden op basis wan de bovengenoemde 3 taakaspecten geen inhoudelijk consistente wragenclusters gevonden. De vraag rijst, waarom het taakopvattingenmodel gehanteerd door Boots (1983) en uitgaand van niet vakgebonden aspecten als taakomvang, taakgerichtheid en taakinhoud, in dit geval geen onderscheidend vermogen bezit ten aanzien van de takopvattingen van vg, ba/vg en ba. Vermoedelijk is het ontbreken van een geaccepteerde en énduidige visie op het verzekeringsgeneeskundig handelen hier debet aan. De discussies binnen de Nederlandse Vereniging voor Verzekeringsgeneeskunde over de taken van de $\mathrm{vg}$, uitmondend in het Advies Sociaal Medische Functie Sociaal Verzekeringsgeneeskundige (NVVG, 1987), wijzen hierop. Hoewel dit Advies een grote mate van convergentie suggereert, blijken vg'n in de praktijk een minder scherp beeld te hebben van hun (toekomstige) taken. Het rapport "Verzekeringsgeneeskundigen over hun werk" (GAK, 1986) toont de onzekerheid en onduidelijkheid over de verzekeringsgeneeskundige taakopvattingen, met name waar het om de begeleidende en adviserende taken gaat.

Daarnaast ervaren ba'n en ba/vg'n de verbreding van de verzekeringsgeneeskundige taken tot preventie en advisering van bedrijven als concurrerend en misschien wel bedreigend. Een éénduidige visie onder $\mathrm{vg}^{\prime} \mathrm{n}$ en ba/vg'n ontbreekt op dit moment. Het ontbreken van een éénduidige visie op en consensus over de taken van de vg maakt het noodzakelijk uit te gaan van de dagelijkse werkzaamheden van vg'n en ba/vg'n, voortvloeiend uit hun wettelijke taak en vorm gegeven door de uitvoeringsorganisaties.

Ten behoeve van de analyse van de taakopvattingen is gekozen voor een takenmodel, dat gebaseerd is op het verzekeringsgeneeskundig handellen, zoals beschreven in paragraaf 1.4.3).

De vg'n en ba/vg'n oefenen een viertal taken uit, die zich richten op hetzij de patiënt/ verzekerde, hetzij de groep verzekerden.

Een tweetal taken richten zich op de patiënt, te weten de beoordelende en begeleidende (reintegrerende) taak. In het verzekeringsgeneeskundig jargon spreekt men van gevalsbehandeling. Bij de uitwoering ervan worden niet alleen gegevens betrokken uit eigen onderzoek, maar ook gegevens verkregen van huisarts en/of specialist en/of werkgever. Daarnaast wordt informatie verschaft aan de patiënt, de huisarts en/of specialist en de werkgever.

Daarnaast kent de vg een viertal taken, die zich richten op groepen patiënten/verzekerden en preventie van ziekteverzuim tot doel hebben, te weten een registrerende, anallyserende, informerende en adviserende taak. Deze vier taken worden tezamen aangeduid als preventie. Deze preventie richt zich op een bedrijf, een afdeling van bedrijf, 
cen cluster bedrijven, een bedrijfstak of verzekerden). De registrerende en analyserende taken betreffen het in kaart brengen en interpreteren van het ziekteverzuim in een patiënten- of verzekerdenpopulatie. De informerende en adviserende taken betreffen het informeren en adviseren van werkgevers, uitvoeringsorganisaties sociale verzekeringen en overheid met betrekking tot het waargenomen ziekteverzuim en maatregelen ter beperking wan ziekteverzuim. In figuur 10 zijn deze taken schematische weergegeven.

Uitgaande van deze dagelijks door de vg of ba/vg uitgevoerde taken werden vragenclusters geformeerd naar soort taak en naar condities om deze taken te kunnen vervullen.

Op basis van factor- en betrouwbaarheidsanalyse zijn een aantal clusters gevormd, die in staat geacht moeten worden te onderscheiden tussen taakopvattingen van $\mathrm{vg}, \mathrm{ba} / \mathrm{vg}$ en ba.

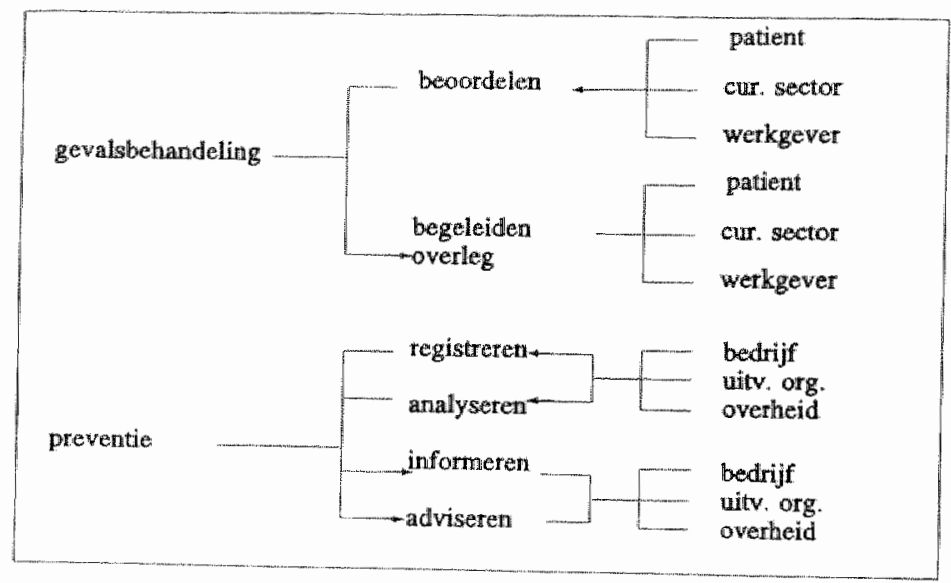

Figurur 10 Taken vg"n en ba/vg'n

\subsubsection{Constructie wan de takinhoudsvariabelen}

\subsubsection{Factor-en betrouwbaarheidsanalyse}

Op basis van de factoranalyse zijn een 8-tal variabelen geconstrueerd, die goed interpreteerbaar en ondubbelzinnig zijn. Een aantal ons inziens relevante items vormden geen onderdeel van deze geconstrueerde factoren. Vandaar dat wij deze resterende variabelen vervolgens op basis van het eerder beschreven takopvattingenmodel zodanig hebben samengevoegd, dat deze items éen taak of én taakkenmerk beschreven. Vervolgens zijn deze op basis van de praktijkervaring gevormde clusters onderzocht op hun interne consistentie. Dit heeft alsnog een 6-tal cluster-variabelen opgeleverd. 
De resultaten van de factoranalyse zijn beschreven in paragraaf 4.22 .2 . De interne consistentie van de 6 overige variabelen is bepaald met behulp van een betrouwbaarheidsanalyse (Cronbach's $\alpha$ ).

Tabel 4.1 bevat een overzicht van de op basis van de factoren betrouwbaarheidsanalyse geconstrueerde variabelen. De variabelen, waarbij de Cronbach's $\alpha$ 's zijn vermeld, zijn geconstrueerd op basis van het eerder beschreven theoretisch model.

Op basis van deze analyses kan worden vastgesteld dat all deze taakwariabelen intern consistent zijn. De variabelen: preventie, bedrijfsrelatie, vertrouwensrelatie en takomvang wijken sterk af van het schaalgemiddelde. Ten aarzien van deze variabelen heeft men in het algemeen een oordeel dat sterk overhelt naar én kant van het continuüm:

- de vg en ba/vg rekenen preventie in mindere mate tot hun taak.

- de ba/vg en ba achten een relatie met het bedrijf belangrijk.

- de ba/vg en vooral de ba vinden een vertrouwensrelatie met de patiënt belangrijk,.

- de ba/wg en ba interpreteren de takopvatting relatief eng.

Tabel 4.1 Statistische kenmerken takopvattingswariabelen $(\mathbb{N}=51$ )

\begin{tabular}{lllllll} 
variabelen & aantal & \multicolumn{2}{c}{ range } & gemid X & SD & Cronb. $\alpha$ \\
& items & hoog & laag & & & \\
\hline 1. controlegerichtheid & 6 & 4.25 & 1.25 & 2.69 & 0.71 & 0.57 \\
2. omgevingsfactoren & 6 & 3.25 & 1.25 & 2.15 & 0.49 & - \\
3. advisering patient & 2 & 5.00 & 0.00 & 2.51 & 1.30 & - \\
4. omgevingsactiviteiten & 6 & 4.25 & 1.25 & 2.42 & 0.63 & 0.61 \\
5. coördinatie & 4 & 5.00 & 1.75 & 3.39 & 0.89 & - \\
6. groepsanalyse & 6 & 4.25 & 1.25 & 2.16 & 0.52 & - \\
7. preventie & 6 & 4.25 & 1.00 & 1.77 & 0.74 & 0.80 \\
8. bedrijfsrelatie & 4 & 4.25 & 1.00 & 1.80 & 0.89 & 0.72 \\
9. hulpmiddelen & 4 & 5.00 & 1.00 & 3.17 & 1.15 & 0.72 \\
10. vertrouwensrelatie & 2 & 4.25 & 1.00 & 1.85 & 0.81 & 0.82 \\
11. relatie cur. sector & 5 & 3.75 & 1.00 & 2.14 & 0.60 & - \\
12. medewerking bedrijf & 2 & 4.25 & 1.00 & 2.37 & 0.68 & - \\
13. talakomvang & 6 & 4.25 & 1.75 & 2.06 & 0.60 & - \\
14. oordeelsvorming & 3 & 4.75 & 1.00 & 2.48 & 0.84 & - \\
\hline
\end{tabular}

\subsubsection{Beschrijving van de taakinhoudelijke variabelen}

De betekenis van de in paragraaf 4.2 .2 .1 beschreven variabelen wordt onderstaand beschreven. Achter tedere variabele is tussen haakjes het variabele-nummer vermeld. ledere variabele bestaat uit 2 to 6 items. De respondenten geven bij iedere stelling op een 5-puntsschaal aan of zij het ermee eens (lage score) of oneens (hoge score) zijn. Per cluster is tussen haakjes de minimaal haalbare (lage) en maximaal haalbare (hoge) score aangegeven, alsook de betekenis van de lage of hoge score. Per taakopvattingscluster zijn de statistische kenmerken weergegeven: het onderscheidend vermogen naar categorie arts. 


\section{a. gevalsbehandeling: beoordeling}

Deze categorie bestaat uit variabelen, die betrekking hebben op de aspecten taakgerichtheid en taakinhoud bij het uitvoeren van de begeleiding: controlegerichtheid en omgevingsfactoren.

De variabele controlegerichtheid [I] geeft aan in welke mate het handelen van de $\mathrm{ug}$ en $\mathrm{ba} / \mathrm{vg}$ in thet licht stalt van de controle. Deze variabele maakt onderscheid wat betreft het aspect takgerichtheid tussen sterk controlerend beoordelen en niet of weinig controlerend beoordelen (tabel 4.2). Een lage score (6) geeft aan dat er sprake is van een sterk op controle gerichte beoordeling. Een hoge score (30) daarentegen geeft aan dat de beoordeling niet of weinig op controle gericht is.

Tabel 4.2 Kenmerken taakopvatingen cluster controlegerichtheid: onderscheidend vemogen naar caltegorie arts: vg $(\mathbb{N}=21), \mathrm{ba} / \mathrm{kg}(\mathrm{N}=14)$ en ba $(\mathrm{N}=16)$

\begin{tabular}{lcccc} 
& laag & midden & hoog & total \\
\hline $\mathrm{vg}$ & 38 & 33 & 29 & 100 \\
$\mathrm{ba} / \mathrm{gg}$ & 19 & 56 & 25 & 100 \\
$\mathrm{ba}$ & & 36 & 64 & 100 \\
\hline totaal & 22 & 41 & 37 & 100 \\
\hline
\end{tabular}

$\mathrm{X}^{2}=10.85$

$p=0.03$

De vg werkt in tegenstelling tot de ba/vg en vooral de ba vanuit een sterk op controle gerichte taakopvatting.

De variabele omgevingsfactoren [2] geeft aan of en in welke mate de vg en ba/vg omgevingsfactoren als werk-, gezins- en familieomstandigheden en sociaal-maatschappelijke omstandigheden laat meewegen bij zijn oordeelsvorming. Dit cluster maakt onderscheid tussen een ruime en enge taakinhoud (tabel 4.3). Een lage score (6) geeft aan dat bij de beoordeling omgevingsfactoren worden meegewogen. Een hoge score (30) geeft aan dat de arts deze ongevingsfactoren niet of nauwelijks meeweegt.

Tabel 4 , Kenmerken takopwattingen cluster omgevingsfatoren: onderscheidend vermogen nuar calcerice arts: $\mathrm{wg}(\mathrm{N}=21)$, ba/vg $(\mathrm{N}=14)$ en ba $(\mathrm{N}=16)$

\begin{tabular}{lcccc} 
& latg & midden & boog & total \\
\hline vg & 10 & 62 & 29 & 100 \\
bat & 38 & 25 & 38 & 100 \\
ba & 14 & 29 & 57 & 100 \\
\hline totalal & 20 & 41 & 40 & 100 \\
\hline
\end{tabular}

$X^{2}=9.42$

$=0.05$ 
De ba/vg weegt de omgevingsfactoren relatief sterker mee in de oordeelsworming dan de ba en $v g$.

\section{b. begeleiding (zogenaamde gevalsbehandeling)}

Deze categorie bevat een drietal variabelen, die betrelkking hebben op de opvatting van de arts over de begeleiding van arbeidsongeschikten. Deze drie variabelen meten resp. de aspecten takomvang en taakinhoud.

De variabele advisering [3] geeft aan of de betreffende arts het adviseren van patienten met betrekking tot het gebruik van medische voorzienimgen tot zijn taak rekent (tabel 4.4). Een lage score (2) betekent dat advisering tot de taak wordt gerekend; een hoge score (10) geeft aan dat de arts deze advisering niet tot de taak rekent.

Tabel 4.4 Kennerken tatakopvattingen cluster advisering: onderscheidend vermogen naar categorie arts: vg $(N=21), b a / v g(N=14)$ en ba $(N=16)$

\begin{tabular}{lcccc}
\hline & laag & midden & hoog & totaal \\
\hline $\mathrm{wg}$ & 19 & 19 & 62 & 100 \\
$\mathrm{ba} / \mathrm{vg}$ & 44 & 25 & 31 & 100 \\
bail & 29 & 21 & 50 & 100 \\
\hline totaal & 29 & 22 & 49 & 100 \\
\hline
\end{tabular}

$\mathrm{X}^{2}=3.78$

$\mathrm{p}=0.44$

Er is geen significant onderscheid met betrekking tot de advisering tussen de 3 categorieën artsen.

De variabele omgevingsactiviteiten [4] geeft aan of de arts de begeleidende activiteiten uitstrekt tot de omgeving van de patiënt en maakt op het aspect taakinhoud onderscheid tussen het bij de begeleiding wel of niet anticiperen op de omgeving van de patiënt.

Tabell 4.5 Kenmerken taskopvattingen cluster ongevingsactiviteiten: onderscheidend verumogen naar categorie arts: $\mathrm{vg}(\mathrm{N}=21)$, ba/vg $(\mathrm{N}=14)$ en ba $(\mathrm{N}=16)$

\begin{tabular}{lcccc} 
& laag & midden & hoog & totaal \\
\hline $\mathrm{vg}$ & 14 & 52 & 33 & 100 \\
$\mathrm{ba} / \mathrm{kg}$ & 50 & 19 & 31 & 100 \\
$\mathrm{ba}$ & 29 & 36 & 36 & 100 \\
\hline totas & 29 & 37 & 33 & 100 \\
\hline
\end{tabular}

$x^{2}=6.76$

$\mathrm{p}=0.15$ 
Met name betreft dit of en in welke mate de curatieve arts en/of de werkgever in voorkomende gevallen betrokken wordt bij de begeleiding (tabel 4.5). Een lage score (6) wijst op een actief beleid ten aanzien van de omgeving van de patient; een hoge score (30) daarentegen geefi aan dat de begeleiding zich beperkt tot de patiënt en diens klachten.

Er is geen significant onderscheid ussen $\mathrm{vg}$, ba/wg en ba wat betreft het wel of niet anticiperen op de omgeving van de patient bij de begeleiding.

De variabele coördinatie 15$]$ geeft aan of en in welke mate de arts de door de huisarts of specialist ingestrlde therapieën wil beinwloeden, met andere woorden: strekt de verzekeringsgeneeskundige begeleiding zich uit tot een afstemming met de curatieve therapie of is er sprake van een strikte scheiding van verzekeringsgeneeskundige begeleiding en curatieve therapie (tabel 4.6). Een lage score (4) geeft aan, dat coördinatie wel tot de taak behoort; een hoge score (20) geeft aan dat coördinatie niet tot de taak behoort.

Tahel 4.6 Kenrnerken taakopwattingen cluster coobdinatie: onderscheidend vermogen naar categorie arts: $v g(N=21)$, balvg $(N=14)$ en bal $(N=16)$

\begin{tabular}{lcccc} 
& larg & midden & hoog & totaal \\
\hline $\mathrm{vg}$ & 38 & 24 & 38 & 100 \\
$\mathrm{ba} / \mathrm{vg}$ & 33 & 27 & 40 & 100 \\
$\mathrm{ba}$ & 36 & 29 & 36 & 100 \\
\hline totaal & 36 & 26 & 38 & 100 \\
\hline
\end{tabular}

$\mathrm{X}^{2}=0.17$

$p=1.00$

Ten aanzien van de coördinatie is er geen significant onderscheidt tussen de $\mathrm{vg}, \mathrm{ba} / \mathrm{vg}$ en ba. De wel of niet op coördinatie gerichte takopvatting komt bij de 3 categorieën artsen in ongeveer dezelfde mate voor.

\section{c. groepsbeoordeling}

Deze categorie bevat vragen over de groepsbeoordeling. Hieronder wordt verstaan het signaleren en analyseren van gegevens over groepen verzekerden: bijvoorbeeld een bedrijs of afdelingspopulatie. Het betreft een aspect van de taakomvang: rekent de arts het hebben van inzicht over arbeid en arbeidsomstandigheden, los van de individuele gevalsbehandeling tot de taak?

Deze categorie bevat efn variabele: groepsanalyse 161. Deze variabele groepsanalyse geeft an of en in welke mate de arts bij de uitoefening van de preventiefunctie behoefte heeft aan informatie vanuit het bedrijf ten behoeve van verzuimpreventie (tabel 4.7). Een lage score (6) geeft aan dat dit wel degelijk tot de taak wordt gerekend; een hoge 
score (30) geeft daarentegen aan dat groepsanalyse niet tot de taak wordt gerekend.

Tabel 4.7 Kemmerken takopwattingen cluster groepsanalyse: onderscheidend wemogen naar categorie arts: $\mathrm{vg}(\mathrm{N}=21)$, ba/vg $(\mathrm{N}=14)$ en ba $(\mathrm{N}=16)$

\begin{tabular}{lcccc}
\hline & laag & midden & hoog & totasl \\
\hline $\mathrm{vg}$ & 33 & 14 & 52 & 100 \\
$\mathrm{ba} / \mathrm{kg}$ & 44 & 25 & 31 & 100 \\
$\mathrm{ba}$ & 29 & 21 & 50 & 100 \\
\hline totaal & 35 & 20 & 45 & 100 \\
\hline
\end{tabular}

$\mathrm{X}^{2}=2.09$

$p=0.72$

Er is geen significant onderscheid met betrekking tot de behoefte aan bedrijfsinformatie ten behoeve van de preventiefunctie. De $\mathrm{vg}$ en ba lijken weinig behoefte te hebben aan deze informatie.

\section{d. groepsbegeleiding: preventie}

Deze categorie betreft de preventie: het actief beïnloeden van het werk en/of de werkomgeving ter voorkoming van ziekteverzuim. Deze categorie bevat een tweetal variabelen, die een taakomvangsaspect en een taakinhoudelijk aspect vertegenwoordigen.

De variabele preventie [7] geeft aan of en in welke mate de arts de preventie, gericht op groepen werknemers tot zijn taak rekent. Dit aspect van de taakomvang betreft die activiteiten, die zich richten op groepen werknemers (bedrijf, afdeling) het optreden van ziekteverzuim door informatie en adviezen te beperken (tabel 4.8).

Een lage score (6) geeft aan dat preventie tot de taak wordt gerekend; een hoge score (30) geeft aan dat preventie niet tot de taak wordt gerekend.

Tabel 4.8 Kenmerken taakopvattingen cluster preventie: onderscheidend vermogen naar categorie arts: $v g(N=21)$, ba/wg $(N=14)$ en ba $(N=16)$

\begin{tabular}{lcccc}
\hline & laag & midden & hoog & total \\
\hline bg & & 24 & 76 & 100 \\
balvg & 19 & 56 & 25 & 100 \\
ba & 36 & 50 & 14 & 100 \\
\hline total & 16 & 41 & 43 & 100 \\
\hline
\end{tabular}

$X^{2}=18.90$

$\mathrm{p} \quad \leq 0.01$

De vg heeft met betrekking tot preventie een zeer expliciete taakopvatting: preventie behoort niet tot de taak. De ba/vg en de ba tonen een veel gedifferentieerder oordeel, waarbij de ba vanuit de taakopvatting het meest op preventie gericht is. 
De variabele bedriffrelotie $[8]$ bevat een taakinhoudelijk aspect en geeft aan of en in welke mate de arts hel noodzakelijk acht het bedrijf te betrekken bij de uitvoering van de preventiefunctie (tabel 4.9). Beschouwt de $\mathrm{vg}$ of ba/vg ondersteuning vanuit en samenwerking met het bedrijf als noodzakelijk en gewwenst?

Een lage score (4) geeft aan dat men het bedrijf wil betrekken bij de uitvoering van de preventiefunctie; een hoge score (20) geeft aan dat deze relatie met het bedrijf niet noodzakelijk cq. wenselijk wordt geacht.

Tabel 4.9 Kenmerken taakopwattingen cluster bedrijfrelatie: onderscheidend vermogen naar categorie arts: $\operatorname{vg}(\mathrm{N}=21)$, bailog $(\mathrm{N}=14)$ en bat $(\mathrm{N}=16)$

\begin{tabular}{|c|c|c|c|c|}
\hline & lasg & midden & hoog & totaal \\
\hline $\mathrm{vg}$ & 5 & 14 & 81 & 100 \\
\hline $\mathrm{ba} / \mathrm{wg}$ & 53 & 33 & 13 & 100 \\
\hline bat & 50 & 50 & & 100 \\
\hline totakal & 32 & 30 & 38 & 100 \\
\hline
\end{tabular}

$\begin{array}{ll}X^{2} & =29.99 \\ p & \leq 0.01\end{array}$

De $\mathrm{vg}$ heeft vrijwel geen behoefte aan informatie van de kant van het bedrijf ten behoeve van de preventiefunctie. De ba/vg en de ba hebben daarentegen wel degelijk behoefte aan deze informatie.

\section{C1. Condities met betrekking tot de gevals-en groepsbegeleiding}

Teneinde de vg taken te kunnen vervullen zal aan een aantal materiële en immateriële condities als hulpmiddelen, vertrouwensrelatie met de patiënt, goede werkrelaties met curatieve sector en werkgevers voldaan moeten worden. Deze categorie bevat een viertal variabelen, die aangeven of men deze condities al of niet noodzakelijk cq. gewenst acht.

De variabele hulpmiddelen [9] geeft aan in welke mate er materiële en immateriële hulpmiddelen ten behoeve van de gevalsbehandeling in de werkomgeving van de arts aanwezig zijn. Het betreft hier niet de vraag of deze hulpmiddelen er zijn, maar de vraag of deze hulpmiddelen er naar de mening van de arts in voldoende of onvoldoende mate zijn (tabel 4.10).

Een lage score (4) geeft aan dat aan de genoemde condities miet of onvoldoende wordt voldaan; een hoge score (20) geeft aan dat aan de genoemde condities in voldoende mate wordt voldaan. 
Tabel 4.10 Kenmerken taakoprattinger cluster hulpmiddefen: onderscheidend vermogen naar catego* rie arts: $\vee g(N=21)$, ba/vg $(N=14)$ en ba $(N=16)$

\begin{tabular}{lcccc}
\hline & lag & midden & hoog & totaal \\
\hline$v g$ & 33 & 33 & 33 & 100 \\
$\mathrm{ba}^{\prime} \mathrm{vg}$ & 13 & 31 & 56 & 100 \\
$\mathrm{ba}$ & 50 & 21 & 29 & 100 \\
\hline totad & 31 & 29 & 39 & 100 \\
\hline
\end{tabular}

$x^{2}=5.60$

$p=0.23$

Hoewel er geen significant onderscheid bestaat met betrekking tot de aanwezigheid van materiële en immateriële hulpmiddelen, lijkt de ba van mening dat de materiële en immateriële hulpmiddelen onvoldoende zijn. Meer dan de helft van de ba/vg'n vindt dat aan deze conditie voldoende wordt voldaan.

Tabel 4.11 Kenmerken taakopvattingen cluster vertrouwensrelatie: onderscheidend vermogen naar categorie arts: $\mathrm{vg}(\mathrm{N}=21), \mathrm{ba} / \mathrm{kg}(\mathrm{N}=14)$ en ba $(N=16)$

\begin{tabular}{lcccc}
\hline & laag & midden & hoog & totaal \\
\hline $\mathrm{vg}$ & 10 & 33 & 57 & 100 \\
$\mathrm{bah} / \mathrm{kg}$ & 19 & 56 & 25 & 100 \\
$\mathrm{bal}$ & 43 & 29 & 29 & 100 \\
\hline totaall & 22 & 39 & 39 & 100 \\
\hline
\end{tabular}

$X^{2}=9.14$
$P=0.06$

De variabele vertrouwensrelatie $[10]$ geeft aan of een vertrouwensrelatie met de patiẻnt noodzakelijk wordt geacht door de arts (tabel 4.11). Een lage score (2) geeft aan dat de vertrouwensrelatie noodzakelijk wordt geacht; een hoge score (10) daarentegen geeft aan dat een vertrouwensrelatie niet noodzakelijk wordt geacht.

Er is geen significant onderscheid met betrekking tot de opvatting over de wenselijkheid van een vertrouwensrelatie tussen $\mathrm{vg}, \mathrm{ba} / \mathrm{vg}$ en ba en patiënt. Meer dan de helft van de vg'n acht een vertrouwensrelatie met de patiënt niet noodzakelijk.

De variabele relatie met curatieve sector [11] geeft aan of en in welke mate de arts een goede werkrelatie met de curatieve sector als voorwaarde beschouwd voor een goede verzekeringsgeneeskundige begeleiding (tabel 4.12). Een lage score (4) geeft an dat deze voorwaarde noodzakelijk wordt geacht; een hoge score (20) geeft aan dat deze conditie niet noodzakelijk is voor een goede verzekeringsgeneeskundige begeleiding. 
Tabel 4.12 Kenmerken taakopwattingen cluster relatie met curatieve sector: onderscheidend vermogen natar caterorie arts: $\mathrm{vg}_{\mathrm{g}}(\mathrm{N}=21)$, ba/ $\mathrm{ge}(\mathrm{N}=19)$ en ba $(\mathrm{N}=16)$

\begin{tabular}{lcccc}
\hline & ladig & midden & hoog & totaal \\
\hline $\mathrm{vg}$ & 29 & 19 & 52 & 100 \\
balvg & 44 & 38 & 19 & 100 \\
bad & 36 & 43 & 21 & 100 \\
\hline total & 35 & 31 & 33 & 100 \\
\hline
\end{tabular}

$X^{2}=6.29$

p $=0.18$

De opvatingen over de noodzaak van een goede werkrelatic met de curatieve sector ligt erg verdeeld binnen de 3 categorieën artsen. Het onderscheid is niet significant. Meer dan de helf wan de $\mathrm{yg}^{\prime} \mathrm{n}$ acht deze relatie niet noodzakelijk.

De wariabele medewerking bedriff 112$]$ geeft aan of en in welke mate er in de relatie met het bedrijf voldoende condities aanwezig zijn om patiènten te kunnen reintegreren (tabel 4.13).

Bij een lage score (2) acht men deze conditie in voldoende mate aawwezig; een hoge score (10) wijst op het ontbreken van deze conditie.

Tabel 4.13 Kenmerken takakopatingen cluster medewerking bedrijf: onderscheidend vermogen naar categorie arts: vg $(N=21)$, batwg $(N=14)$ en ba $(N=16)$

\begin{tabular}{lcccc} 
& laag & midden & hoog & total \\
\hline $\mathrm{vg}$ & 14 & 29 & 57 & 100 \\
$\mathrm{ba} / \mathrm{vg}$ & 31 & 44 & 25 & 100 \\
$\mathrm{ba}$ & 21 & 50 & 29 & 100 \\
\hline totatal & 22 & 39 & 39 & 100 \\
\hline
\end{tabular}

$X^{2}=5.27$

$\beta=0.26$

Ten aanzien van de medewerking van het bedrijf aan reintegraties zijn de opvattingen verdeeld. Het onderscheid is niet significant. Meer dan de helft van de vg'n geeft aan, dat deze condities niet vervuld zijn.

De variabele oordeelsvorming 114$]$ geeft an op welke wijze de tot een oordeel komt en makt onderscheid tussen de zakelijke, sterk op de wetsuitvoaring gerichte oordeels vorming en de anticiperende, meer op de patiënt gerichte oordeelsvorming (tabel 4.14). Een lage score (3) wijst op een op de wetsuitvoering gerichte oordeelsvorming; een hoge score (15) wijst op een anticiperende, meer op de patiënt gerichte oordeelsvorming. 
Tabel 4.14 Kenmerken takkopwattingen duster oordeelswommug: onderscheidend vermogen anar categorie arts: vg $(\mathbb{N}=21)$, ba/vg $(N=14)$ en ba $(N=16)$

\begin{tabular}{lcccc}
\hline & laag & midden & hoog & totaal \\
\hline $\mathrm{vg}$ & 48 & 38 & 14 & 100 \\
$\mathrm{ba} / \mathrm{kg}$ & 25 & 31 & 44 & 100 \\
$\mathrm{ba}$ & 29 & 21 & 50 & 100 \\
\hline total & 35 & 31 & 33 & 100 \\
\hline
\end{tabular}

$X^{2}=6.28$

$\mathrm{p} \quad=0.18$

Er is geen significant onderscheid met betrekking tot de oordeelsvorming. De $\mathrm{vg}$ is wat meer op de wetsuitvoering gericht. De ba/vg en vooral de ba tenderen naar een taakopvating, van waaruit zij meer anticiperen op de patiënt.

\section{Visie op de taakonvang}

De categorie "Visie op de taakomvang" bevat in de variabele taakomvang (13) een aantal uitspraken met betrekking tot de taakomvang. Deze variabele geeft aan of en in welke mate de arts naast de gevalsbehandeling ook de preventie en het verzekeringsgeneeskundig consulentschap ten behoeve van de curatieve sector als taak ziet (tabel 4.15).

Tabel 4.15 Kenmerken taakopvattingen cluster takkomvang: onderscheidend vermogen naar categorie arts: $\operatorname{vg}(\mathrm{N}=21)$, ba/wg $(\mathrm{N}=14)$ en ba $(\mathrm{N}=16)$

\begin{tabular}{lcccc}
\hline & laag & midden & hoog & lotal \\
\hline$v g$ & 5 & 14 & 81 & 100 \\
$\mathrm{ba} / \mathrm{vg}$ & 38 & 38 & 25 & 100 \\
$\mathrm{ba}$ & 71 & 21 & 7 & 100 \\
\hline total & 33 & 24 & 43 & 100 \\
\hline
\end{tabular}

$\mathrm{X}^{2}=25.82$

$\mathrm{p} \leq 0.01$

Een lage score (6) geeft aan dat men opteert voor een enge, beperkte taakomvang in deze; een hoge score (30) daarentegen geeft aan dat men een ruime takomvang wenst.

Er is een significant onderscheid met betrekking tot de taakomvang. De vg toont zich hier alls de arts, die de taakomvang zeer ruim ziet. De ba/vg en vooral de ba zien hun takomvang aanzienlijk beperkter.

Op basis van de hierboven beschreven variabelen worden de takopvattingen van 3 categorieën artsen (vg, ba/vg en ba) en de verschillen in taakopvattingen in kaart gebracht en beschreven in paragraaf 4.3 . 
In paragraat 4.4 zall een herclustering, specifiek gericht op de verschillen in taakopvatting van de vg en ba/vg beschreven worden; de ba wordt in dit deel wan het onderzoek niet betrokken.

Deze herclustering zal in hoofdstuk 5 gebruikt worden bij de effectanalyse ten aanzien van de arbeidsongeschiktheidsduur.

\subsection{Analyse taakopvattingen: resultaten}

In dit hoofdstuk zullen de waargenomen verschillen in taakopvatting tussen de drie categorieën artsen aan de hand van de analyseresultaten besproken worden.

Allereerst zal in paragraaf 4.3.1 worden ingegaan op de resultaten van de $X^{2}$-test. Vervolgens zullen in paragraaf 4.3 .2 de resultaten van de discriminant-analyse worden besproken.

In paragraaf 4.3 .3 zullen ten slotte op basis van de resultaten van de $X^{2}$-test en de discriminant-analyse de verschillen tussen de 3 categorieën artsen op een rij worden gezet en het onderscheid tussen de categorieën worden aangegeven.

\subsubsection{Verschillen in taakopvatting}

Met behulp van de chi-quadraattest $\left(\mathrm{X}^{2}\right)$ is de totale artsenpopulatie onderscheiden in drie groepen: laag, midden en hoog. Vervolgens is deze score per variabele afgezet tegen de 3 categorieën artsen. Hoe meer een bepaalde categorie artsen oververtegenwoordigd is, thoe hoger zal de $\mathrm{X}^{2}$ zijn. Hiermede is het mogelijk te bepalen welke variabelen onderscheid maken tussen de 3 categorieën artsen. In tabel 4.16 is het resultatat van deze analyse opgenomen.

Tabel 4.16 Statistische kenmerken takopvattingen-clusters: onderscheidend vermogen naar categorie arts

\begin{tabular}{|c|c|c|}
\hline variabelen & $x^{2}$ & \\
\hline 1. controlegerichtheid & 10.85 & * \\
\hline 2. omgevingsfactoren & 9.42 & $* *$ \\
\hline 3. Hivisering & 3.78 & \\
\hline 4. ongev nustastivitethen & 6.76 & \\
\hline 5. chordinatie & 0.17 & \\
\hline 6. growestratyse & 2.09 & \\
\hline 7 proventie & 18.90 & w \\
\hline 8. bedrijfsrelatie & 29.99 & 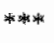 \\
\hline 9. hulpmiddien & 5.60 & \\
\hline 10. vertromwemsrelatie & 9.14 & * \\
\hline 1. rolutie mat cur. seet. & 6.29 & \\
\hline 12. medluwerking bednij & 5.27 & \\
\hline 13. takkomwang & 25.82 & * * * \\
\hline 14. oordeclsworming & 6.28 & \\
\hline
\end{tabular}

*⿻一𠃋十 $0.01<\mathrm{p}<0.05$

$0.05<1 \leq 0.10$ 
De $X^{2}$-test toont een significant verschil in taakopvatting wat betreft de variabelen controlegerichtheid, omgevingsfactoren, preventie, bedrijfsrelatie, vertrouwensrelatie en taakomvang; Het sterkste onderscheid wordt gemaakt op basis van de opvattingen over preventie, bedrijfsrelatie en visie. Op deze 3 variabelen helt het oordeel van de ba/vg en ba sterk naar dezelfde kant over.

$\mathrm{Ba} / \mathrm{vg}$ en ba rekenen beide de preventie tot hun taak en zijn zeer sterk op het bedrijf gericht. De vg daarentegen is vrijwel niet gericht op preventie en acht een relatie met het bedrijf het minder noodzakelijk dan de ba/vg en ba.

Ten aanzien van de takomvang hebben de ba/vg en vooral de ba een beperkte visie; dit in tegenstelling tot de vg, die zijn taakomvang daarentegen juist ruim ziet.

Bovendien is de $\mathrm{vg}$ meer dan de ba/vg en ba van mening dat bij de beoordeling van patiënten het controle-aspect zeer belangrijk is.

\subsubsection{Onderscheid tussen verzekeringsgeneeskundige, bedrijfsarts/verzekerings- geneeskundige en bedrijfsarts}

Vervolgens is onderzocht in hoeverre de variabelen onderscheid kunnen maken tussen de 3 categorieën artsen. Met behulp van de discriminant-analyse is nagegaan of, en zo ja in welke mate een variabele onderscheid maakt tussen de vg en ba, de vg en ba/vg, en de ba en ba/vg. Hierbij is gekozen voor de discriminant-analyse volgens Wilks. In deze paragraaf zullen na een bespreking van de discriminant-analyse achtereenvolgens aan de orde komen:

in paragraaf 4.3.2.1: het onderscheid tussen $\mathrm{vg}$ en ba;

in paragraaf 4.3.2.2: het onderscheid tussen $\mathrm{vg}$ en ba/ $/ \mathrm{kg}$, en

in paragraaf 4.3.2.3: het onderscheid tussen ba/vg en ba.

De discriminant-analyse geeft aan welke variabelen de hoogste voorspellende waarde hebben ten aanzien van de categorieën: $\mathrm{vg}$, ba/vg of ba. Alle 14 variabelen werden betrokken bij de discriminant-analyse (zie paragraaf 4.2.2.2).

Bij de discriminant-analyse is voor iedere categorie arts een discriminant-score gevormd door middell van de discriminant-functie, waarin de scores op de variabelen op dusdanige wijze worden gecombineerd dat het verschil tussen groepen maximaal is. De mate waarin een variabele aan deze discriminant-functie bijdraagt geeft een aanwijzing over de bijdrage van de variabele aan het verschil tussen de beide categorieën.

Bovendien wordt de gemiddelde score van elk der beide groepen aangegeven op de discriminant-functie (de discriminant-functie op groepsgemiddelden).

De analyse leverde een significante discriminant-functie op $(p \leq 0.05)$. De selectie van de variabelen voor deze discriminant-functie geschiedde op grond van de minimale warde van de Wilks-lambda.

Het overall-criterium is de F-ratio voor de test op de verschillen tussen groepsgeniddelden. Deze toets neemt daarbij in de berekening het verschil mee tussen de middel- 
purten en de cohesie (homogeniteit) binnen de groep. Deze analyse is gevolgd voor elk van de 14 variabelen (clusters).

De analyseprocedure werd gestopt, indien

1. de afname van de Wilks lambda niet meer significant was. De Wilks lambda is een inverse maat voor het discriminerend vermogen van de variabelen. Indien deze bij een volgende stap (toevoeging nieuwe variabele) niet significant kleiner wordt, dan wordt evenmin het discriminerend vermogen tussen groepen geselecteerde variabelen groter.

2. de F-waarde van de geselecteerde variabele (cluster) onvoldoende was voor verdere berekening $(p>0.05)$.

\subsubsection{Onderscheid tussen verzekeringsgeneeskundige en bedrijfsarts}

Het verschil in taakopvatting tussen vg en ba wordt vooral bepaald door de opvattingen over de relatie met het bedrijf en een actief beleid ten aanzien van de omgeving bij de begeleiding van patiënten (tabel 4.17). De discriminant-functie op groepsgemiddelden is weergegeven in tabel 4.18 .

Tabel 4.17 Onderscheid $\mathrm{wg}$ - ba, discriminant-functie

\begin{tabular}{lc} 
variabelen & discriminant-functie \\
\hline 3. advisering & -0.40 \\
4. omgevingsactiviteit & -0.98 \\
7. preventie & 0.51 \\
8. bedrijfsrellatie & 2.09 \\
10. vertrouwensrelatie & -0.42 \\
13. taakomwang & 0.90 \\
14. oordeelsvorming & 0.39 \\
\hline
\end{tabular}

Wilks lambda: 0.22

$\mathrm{X}^{2} \quad: 44.62$

$\mathrm{p} \quad \leq 0.01$

De discriminant-functie op groepsgemiddelden geeft de waarde aan op de schaal, waarop de variabelen worden uitgezet tussen vg en ba, afhankelijk van hun waarde op de genoemde variabelen (tabel 4.18). Het verschil in waarde tussen $\mathrm{vg}$ en ba is groot. De ba richt zich vanuit zijn taakopvatting op het bedrijf en is vooral gericht op de preventie. De ba toont zich meer gericht op de omgeving van de patiënt en heeft een engere taakopvatting. Hij lijkt zich vooral te richten op de bedrijfsgezondheidszorg en rekent de verzekeringsgeneeskunde niet tot zijn taak.

Tabel 4.18 Discriminant-functie op groepsgemiddelden

\begin{tabular}{lc} 
categorio arts & discriminant-functie \\
\hline $\mathrm{vg}$ & 1.49 \\
$\mathrm{ba}$ & -2.24 \\
\hline
\end{tabular}


De vg is vooral op de patient gericht en hecht grote waarde aan de wetsuitvoering an, vanuit zijn rume wisie ten aanzien van de takomvang, aan de advisering van de curatieve sector; de vg hecht weing belang aan een vertrouwensrelatie met de patiënt.

Gegeven deze verschillen in taakopvatting ussen vg en ba is het mogelijk op grond van takkopwattingen een voorspelling te doen ten aanzien van de categorie, wartoe de arts behoort. Tabel 4.19 geeft aan in welke mate op basis van de takopvattingsvariabelen een juiste voorspelling kan worden gedaan met betrekking tot de categorie, waar toe de arts behoort. Wat de vg en ba betreft is het in 34 van 35 gevallen (97\%) op basis van de taakopvattingen mogelijk een juiste voorspelling te doen.

Tabel 4.19 Discriminant-analyse: voorspelling op basis wan takkopvatting - ba

\begin{tabular}{|c|c|c|c|}
\hline \multirow[t]{2}{*}{ calegorie arts } & \multirow[t]{2}{*}{ gantal artsen } & \multicolumn{2}{|c|}{ voorspelling } \\
\hline & & $\mathrm{vg}$ & ba \\
\hline $\operatorname{vg}$ & 21 & 20 & 1 \\
\hline ba & 14 & 0 & 14 \\
\hline
\end{tabular}

\subsubsection{Onderscheid tussen verzekeringsgeneeskundige en bedrijfsarts/verzeke- ringsgeneeskundige}

De verschillen in taakopvatting tussen de $\mathrm{vg}$ en ba/ $\mathrm{vg}$ worden in sterke mate bepaald door de opvattingen ten aanzien van de preventie en vertrouwensrelatie (tabel 4.20). De vg vindt een vertrouwensrelatie aanzienlijk minder bellangrijk dan de ba/vg. De $\mathrm{ba} / \mathrm{vg}$ richt zich in tegenstelling tot de $\mathrm{vg}$ sterk op preventie, op groepen patiënten (bijvoorbeeld een bedrijf). In vergelijking met de $v g$ hecht de ba/vg meer belang aan een goede medewerking van het bedrijf, maar bezitt een engere opvatting over de taakomvang. De discriminant-functie op groepsgemiddelden is weergegeven in tabel 4.21 .

Gegeven deze significante verschillen in takopwatting tussen vg en ba/vg is het mogelijk op grond van taakopvattingen een voorspelling te doen ten aanzien van de categorie, waartoe de arts behoort. Tabel 4.22 geeft aan in welke mate op basis van de taakopvattingsvariabelen een juiste woorspelling kan worden gedaan met betrekking tot de categorie, waartoe de arts behoort.

Tabel 4.20 Onderseheid $\mathrm{wg}$ - ba/vg: discriminant-functie

\begin{tabular}{lc}
\hline variabilen & discriminant-furictie \\
\hline 2. omgewingsfactoren & 0.95 \\
6. groepsanalyse & 0.73 \\
7. preventie & 0.43 \\
10. vertrouwensmelatie & 1.10 \\
12. medewerking bedriff & 0.61 \\
13. takkonvang & 1.01 \\
\hline
\end{tabular}

Wiks lambda: 0.53

$\begin{array}{ll}X^{2} & : 19.11 \\ p & \leq 0.01\end{array}$ 
Tabel 4.21 Discriminant-functie op groepsgemiddelden

\begin{tabular}{|c|c|}
\hline ategorie ants & dimoriminant-functie \\
\hline $\mathrm{Pg}$ & 0.75 \\
\hline$b a$ & -1.12 \\
\hline
\end{tabular}

De discriminant-functie op groepsgemiddelden toont tussen $\mathrm{vg}$ en ba/vg een minder groot werschill (tabel 4.21) dan tussen vg en ba (tabel 4.18).

De voorspellende waarde van dexe taakopvattingsvariabelen is minder dan de voorspellende waarde van de analyse van het onderscheid tussen vg en ba. Op zich niet verwonderlijk gelet op de grotere mate van overlap in taken van de vg en ba/vg. Desalniettemin is het in 29 van de 37 gevallen (78\%) mogelijk om op basis van de taakopvattingen een juiste voorspelling te doen ten aanzien van de categorie arts (tabel 4.22).

Tabel 4.22 Discriminant-anallyse: voorspelling op basis van talakopvatting $\mathrm{vg}-\mathrm{ba} / \mathrm{vg}$

\begin{tabular}{|c|c|c|c|}
\hline \multirow[t]{2}{*}{ cutegorie arts } & \multirow[t]{2}{*}{ aantal artsen } & \multicolumn{2}{|c|}{ voorspelling } \\
\hline & & $\mathrm{vg}$ & ba \\
\hline $\mathrm{vg}$ & 21 & 16 & 5 \\
\hline $\mathrm{ba}$ & 16 & 3 & 13 \\
\hline
\end{tabular}

\subsubsection{Onderscheid tussen bedrijfsarts/verzekeringsgeneeskundige en bedrijfsarts}

Het onderscheid in taakopvatting tussen ba/vg en ba wordt bepaald door slechts 4 variabelen (tabel 4,23). De discriminant-functie op groepsgemiddelden is weergegeven in tabel 4.24). De ba/vg kenmerkt zich door een in vergelijking met de ba grote controllegerichtheid en vindt het belangrijk te werken vanuit een vertrouwensrelatie, hoewel ten aanzien van dit laatste het verschil in opvatting tussen ba/vg en ba gering is. De ba heeft een engere visie op taakomvang en acht bovendien de hulpmiddelen te kort schieten.

Tabel 4.23 Onderscheid ba/vg - ba: discriminant-functie

\begin{tabular}{|c|c|}
\hline Variabellen & discriminant-functio \\
\hline 1. contrologerichtheid & -1.05 \\
\hline 9. hulpiriddelen & 0.57 \\
\hline 10. vertrow wensrelatie & -0.41 \\
\hline 13. tankomvang & 0.82 \\
\hline
\end{tabular}

Wilks lambda: 0.60

$x^{2}: 12,06$

p : 0.02 
Tabel 4.24 Discrimingat-functie op groepsgeniddelden

\begin{tabular}{lc}
\hline categorie arts & discrimingentunctie \\
\hline $\mathrm{vg}$ & 0.78 \\
$\mathrm{ba}$ & -0.78
\end{tabular}

De discriminantfunctie op groepsgemiddelden toont tussen ba/vg en ba een gering verschil (tabel 4.24), geringer dan tussen vg en ba en tussen $\mathrm{vg}$ en ba/ $\mathrm{vg}$.

Gegeven deze significante verschillen in taakopvatting tussen ba en ba/vg is het mogelijk op grond van taakopvattingen een voorspelling te doen ten aanzien van de categonie, waartoe de arts behoort. Zoals tabel 4.25 laat zien, is het in 23 van 30 gewallen mogelijk op basis van de taakopvattingsvariabelen een juiste woorspelling te doen met betrekking tot de categorie arts: ba en ba/vg.

Tabel 4.25 Discriminant-analyse: voorspelling op hasis ran taakopratting bu/vg - ba

\begin{tabular}{|c|c|c|c|}
\hline \multirow[t]{2}{*}{ categorie arts } & \multirow[t]{2}{*}{ aantal artsen } & \multicolumn{2}{|c|}{ voorspelling } \\
\hline & & $\mathrm{vg}$ & $b a$ \\
\hline$v g$ & 16 & 11 & 5 \\
\hline bat & 14 & 2 & 12 \\
\hline
\end{tabular}

Het aantal juiste voorspellingen ten aanzien van de categorieën arts: ba/vg en ba, is lager dan het aantal juiste woorspellingen bij $\mathrm{vg}$ - ba en $\mathrm{vg}$ - ba/vg: 23 van de 30 $(77 \%)$ Dit is niet opmerkelijk gelet de grotere overeenkomst in taken tussen ba/vg en ba, waarbij de bedrijfsgeneeskundige taken de verzekeringsgeneeskundige taken lijken the overheersen.

\subsubsection{Samenvatting van de analyse-resultaten}

Aan de hand van de resultaten van $\mathrm{X}^{2}$-test en de discriminant-analyse ontstat het volgende beeld ter aanzien wan de taakopvattingen van de $\mathrm{vg}$, de ba/vg en de ba.

De $v g$ is vooral op de sturing van de patiënt gericht. Hierbij staat de formele taak en de wetsuitvoering voorop. De $v g$ hecht geringe waarde aan het bestaan van cen vertrouwensrelatie en richt zich vanuit een ruime opvatting ten aanzien van de taakomvang op de omgeving wan de patiënt. Bij de reintegratie heeft de $y g$ in mindere mate behoefte aan informatie vanuit het bedrijf. De wg kan op basis van zijn opvattingen als een sturings(taak) gerichte arts worden beschouwd.

$\mathrm{De} \mathrm{ba} / \mathrm{vg}$ is vooral op de omgeving gericht; hieronder worden zowel groepen patiënten als het bedrijf verstaan. Vanuit deze omgevingsgerichtheid is hij geinteresseerd in de preventie. Vanuit deze taakopvatting hecht hij veel waarde aan de relatie met patiënten, het bedrijf en de curatieve sector. De ba/vg kan gekarakteriseerd worden als relatlegericht. 
De ba richt zich vooral op het bedrijf en is erg op resultaat gericht. De ba acht de middelen om zijn doel te bereiken te beperkt. Zijn invalshoek is de preventie. Zijn opvathing over de takomvang is beperkter dan die van de vg en ba/vg. De ba idenwifceert zich meer met de bedrijfsgezondheidszorg dan met de verzekeringsgeneeskunde. De ba kan op basis van de takopvattingen gekarakteriseerd worden als bedrifisgerich.

De verschillen in takapvattingen weerspiegelen de verschillen in taken van de 3 categorieën artsen. Als de takopvattingen van $\mathrm{vg}$ en ba als uitersten - sturings(taak)gericht wersus bedrijfsgericht - worden beschouwd, staat de ba/vg in zijn taakopvatting tussen vg en ba, zij het dichter bij de ba dan bij de vg.

\subsection{Constructie van taakinhoudsvariabelen ten behoeve van de effectmeting}

In de voorgaande paragrafen zijn de verschillen in taakopvatting tussen de $v \mathrm{~g} / \mathrm{ba} / \mathrm{vg}$ en ba beschreven. Dit vormde een nevenvraag, die mogelijk een bijdrage zou kunnen leveren an de centrale vraag van dit onderzoek, namelijk in hoeverre is een bepaalde takopvatting, naast andere aspecten als categorie arts en de door de $\mathrm{vg}$ of ba/vg verrichte activiteiten, van invloed op de arbeidsongeschiktheidsduur. We keren nu dus terug tot de belangrijkste vraagstellingen van dit onderzoek: 1 , bestaan er verschillen in arbeidsongeschiktheidsduur binnen de verzorgde populatie en 2 , bestaat er een samenhang tussen verschillen in arbeidsongeschiktheidsduur en categorie arts (vg of ba/vg), diens taakopvatting en persoons- en werkkenmerken van de arts. De taakopvatting is vanuit deze vraagstellingen een onafhankelijke (artsgebonden) variabele, die van invloed kan zijn op de verzuimduur. Zoals eerder gesteld, zullen we ons in dit deel van het onderzoek beperken tot taakopvattingen van de $\mathrm{vg}$ en ba/vg.

On de taakopwatting als onathankelijke variabele te kunnen gebruiken is een herclus tering noodzakelijk. Deze herclustering is niet gericht op het onderscheid tussen de $\mathrm{vg}$ en ba/vg, maar op het definiëren van de bij vg en ba/vg voorkomende taakopvattingen in relatie tot het effect op de begeleiding en het begeleidingsresultaat. Bovendien is het ondoenlijk en onverstandig een 14-tal clusters als onafhankelijke variabelen te thanteren ten aanzien van de effectmeting met betrekking tot de $2.1 \mathrm{Vg}$ 'n en de $14 \mathrm{ba} / \mathrm{vg}^{\text {"n }}$ (zie tabel 3.2). De kans op kanskapitalisatie is hierdoor te groot. Om deze redenen is besloten de 14 takopvattingenclusters met behulp van de factoranalyse te reduceren tot een 3-tal nieuwe variabelen (tabel 4.26). Indien een van de oorspronkelijke clusters een bijdrage levert aan 2 of 3 factoren, is dit cluster toegerekend aan de factor, waaraan het de hoogste bijdrage levert, mits dat cluster cen betekenis heeft, die consistent is met de andere clusters binnen deze factor. Tevens is per factor de zogenaamd verklaarde variantie aangegeven. Het in deze rij vermelde percentage is een maat van de bijdrage van de betreffende factor aan het verschil tussen de factoren. Een beschrijving van de oorspronkelijke 14 clusters is opgenomen in paragraaf 4.2 .2 .2 . Bijlage 4 bevat de statistische kenmerken van de takopvatingsfactoren. 
Hiermede worden de oorspronkelijke 14 taakopvattingsvariabelen beperkt ten behoeve van de effectmeting tot een 3-tal onafhankelijke factoren. Onderstaand en in hoofdstuk 5, Resultaten, zullen deze factoren aangeduid worden als variabelen. Deze 3 variabelen tezamen verklaren $48 \%$ van de variantie tussen de oorspronkelijke clusters.

Tabel 4.26 Clustering taakopwattingen ten behoeve van effectmeting: factorladingen

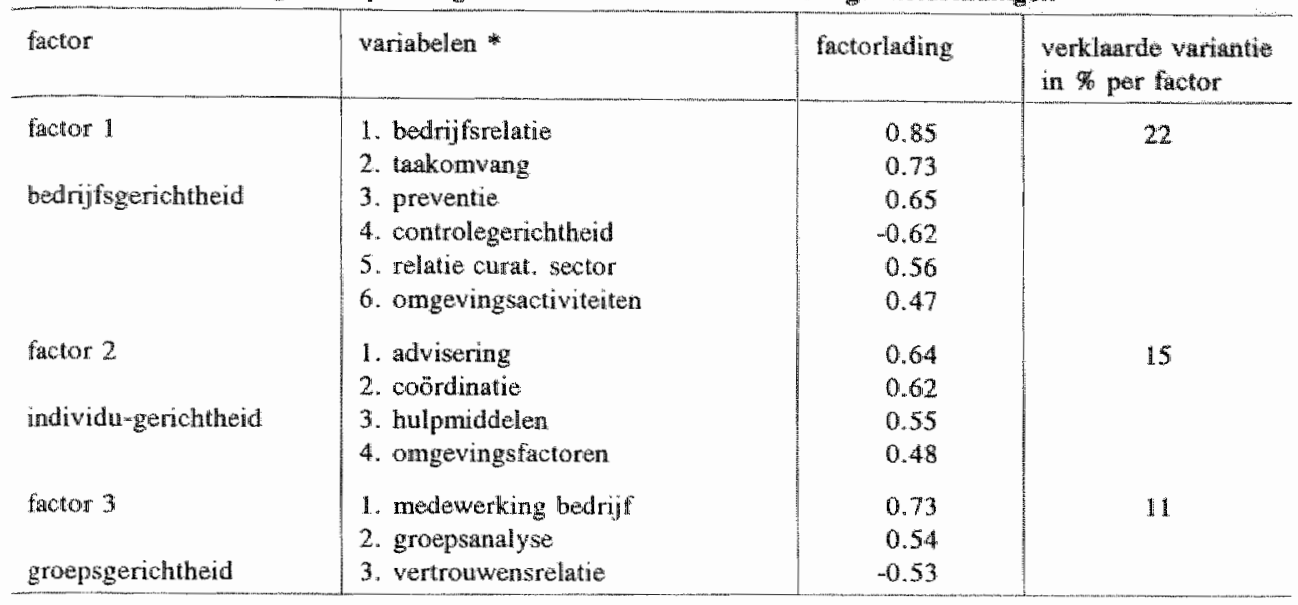

* Variabele 14 (cordleelsvorming) levert onwoldoende bijdrage aan én der factoren en is derhalve niet vernelld.

Inhoudelijk kunnen deze 3 nieuwe factoren alls volgt beschreven worden:

Factor 1 beschrijft de arts met de volgende taakopvatting:

1. sterk/weinig op controle gericht;

2. niet/wel anticiperend op de omgeving van de patiënt;

3. nuiet/wel gericht op de preventie;

4. geen/wel relatie met het bedrijf;

5. geen/wel relatie met de curatieve sector, en

6. een brede/snalle visie op de taakomvang.

Deze factor maakt onderscheid tussen: de actief versus passief op de reïntegratie in het bedrijf gerichte arts. Artsen met een actieve taakopvatting in deze zetten zich in voor de rë̈ntegratie van hun patiënten en preventie van ziekteverzuim; zij betrekken hierbij actief het bedrijf. Deze factor wordt benoemd als bedriffsgerichtheid. Een lage score betekent cen hoge mate van bedrijfsgerichtheid; een hoge score betekent een geringe mate van bedrijfsgerichtheid.

Factor 2 beschrijft de arts met de volgende taakopvatting:

1. niet/wel gericht op de omgeving van de patiënt; 
2. geen/wel advisering van de patient met betrekking tot het gebruk van medische voorzieningen;

3. geen/wel coördinerende taak naar de curatieve sector, en

4. voldoende/onvoldoende hulpmiddelen voor diagnostiek en begeleiding.

Deze factor makt onderscheid tussen de artsen, die zich bij de oordeelsvorming en begeleiding wel versus die zich nief richten op de individuele patiènt én de omgeving van de patient. Artsen met een positieve taakopvatting in deze adviseren hun patienten met betrekking tot het gebruk van medische voorzieningen en trachten een afstemming tussen de verzekeringsgeneeskundige begeleiding en door de curatieve artsen ingestelde therapieen te bewerksteligen. Deze factor wordt benoemd als individu-gerichtheid. Een lage score betekent een hoge mate van individu-gerichtheid; een hoge score betekent een geringe mate van individu-gerichtheid.

Factor 3 beschrijft de arts met de volgende taakopvatting:

1. niet/wel gericht op het bedrijf als informatiebron ten behoeve van de oordeelsworming:

2. hecht veel/weinig belang aan het bestaan van een vertrouwensrelatie met de patiënt, èn

3. de medewerking van het bedrijf is onvoldoende/voldoende.

Deze factor differentieert tussen artsen, die relatief sterk gericht zijn op de analyse op groepsniveau $\mathrm{cq}$. het bedrijf en artsen, die hierop relatief zwak gericht zijn. Bij eerstgenoemden speelt de individuele patiënt geen rol. Ook de vertrouwensrelatie met de patiënt is hier van ondergeschikt belang. Artsen met deze groepsgerichte taakopvatting zijn vooral geinteresseerd in bedrijfsfactoren, die leiden tot een verstoring van de gezondheid van de patiënt en het optreden van arbeidsongeschiktheid. Deze factor wordt benoemd als groepsgerichiheid. Een lage score betekent een hoge mate van groepsgerichtheid; een hoge score betekent een geringe mate van groepsgerichtheid.

Op basis van de bovenstaande 3 factoren zijn taakopvattingswariabelen geconstrueerd doot sommatie van de waarden van de wariabelen, die een hogere factorlading dan 0.45 hebben in de factoranalyse.

Uiteraard rijst de vraag in hoeverre de hiervoor beschreven 3 taakopvattingsvariabelen een onderscheid maken tussen dan wel representatief zijn voor de 3 categorieën artsen: de $v g, b a / v g$ en ba. Met behulp van de $T$ test is nagegaan hoe de 3 categorieen artsen scoren op de 3 taakopvattingswariabelen en of de waargenomen verschillen in score significant zijn. Ter verduidelijking: de taakopvattingsvariabele groepsgerichtheid bestat uit de clusters groepsanalyse, vertrouwensrelatie en medewerking bedriff. De geniddelde score per cluster is gedeeld door het aantal items, waaruit de betreffende cluster bestat. Summerend geeft dit de gemiddelde waarde per item. Deze bewerking is noodzakelijk omdat de range per cluster (afhankelijk van het aantal items per cluster) tenggebracht moet worden tot de gemiddelde waarde per item. Tabell 4.27 bevat 
een overzicht van de resultaten van de T-test. De belangnjkste statistische kenmerken van de taakopwattingsfactoren zijn opgenomen in bijlage 4.

Tabel 4.27 T-toetsgegewens betreffende takkopwattingswariabelen tussen $\mathrm{wg}(\mathrm{N}=21), \mathrm{ba} / \mathrm{vg}(\mathrm{N}=13)$ en ba $(\mathbb{N}=16)$

\begin{tabular}{|c|c|c|c|}
\hline \multicolumn{4}{|c|}{ bedrijtsgerioth heid } \\
\hline$v_{g}$ & baivg & $\mathrm{ba}$ & $T$-waarde \\
\hline $\begin{array}{l}11.14 \\
11.14\end{array}$ & $\begin{array}{l}7.04 \\
7.04 \\
\end{array}$ & $\begin{array}{r}6.08 \\
6.08 \\
\end{array}$ & $\begin{array}{c}6.84 * 4 \\
10.20 \\
1.78\end{array}$ \\
\hline \multicolumn{4}{|c|}{ individu-gerichtheid } \\
\hline $\mathrm{vg}$ & balug & ba & Tuwwarde \\
\hline $\begin{array}{l}11.33 \\
11.33\end{array}$ & $\begin{array}{l}11.05 \\
11.05\end{array}$ & $\begin{array}{l}11.30 \\
11.30 \\
\end{array}$ & $\begin{array}{r}0.34 \\
0.04 \\
-0.30\end{array}$ \\
\hline \multicolumn{4}{|c|}{ groepsgerichtheid } \\
\hline$v g$ & $\mathrm{ba} / \mathrm{kg}$ & ba & T-waarde \\
\hline $\begin{array}{l}2.46 \\
2.46\end{array}$ & $\begin{array}{l}3.16 \\
3.16\end{array}$ & $\begin{array}{l}2.55 \\
2.55 \\
\end{array}$ & $\begin{array}{r}-1.60 \\
-0.18 \\
1.30 \\
\end{array}$ \\
\hline
\end{tabular}

$* * * * * 05<0.01$
$* 0.05 \leq 0.10$

De verschillen tussen de 3 categorieën artsen zijn uitsluitend significant wat betreft de taakopvattingsvariabele: bedrijfsgerichtheid. Hierbij valt op dat wat de taakopvatting bedrijfsgerichtheid betreft het verschil tussen $\mathrm{vg}$ en ba het grootst is.

Een verklaring hiervoor kan gelegen zijn in enerzijds taakverschillen, anderzijds de afstand tussen arts en bedrijf. Wat de taak betreft, de $\mathrm{vg}$ heeft een aan de wet ontleende expliciete verzekeringsgeneeskundige taak: controle en reüntegratie; de ba daarentegen heeft vooral een bedrijfsgezondheidszorgtaak. De vg zal zich vanuit zijn opdracht meer richten op de patiënt en minder op het bedrijf. De vg heeft daarnaast een betrekkelijk grote afstand tot het bedrijf. Is de ba/vg in de regel in dienst van en werkzaam binnen (de bedrijfsgezondheidsdienst van) een of enige bedrijven, de vg werkt vrijwel altijd vanuit de uitvoerende instelling (Bedrijfsvereniging of GAK) en verzorgt een zeer groot aantal bedrijven.

De ba/vg heeft zowel een verzekeringsgeneeskundige als een bedrijfsgezondheidszorg taak. De ba/vg zal overigens net als de ba in de regel verbonden zijn aan een of enkele bedrijven. Het is dan ook niet verwonderlijk dat het onderscheid tussen $\mathrm{vg}$ en ba/vg wat de takopvatting bedrijfsgerichtheid betreft eveneens significant is alls ook het onderscheid tussen ba en ba/vg, zij het in mindere mate. 
De taakopvattingsfactor individu-gerichtheid en groepsgerichtheid maken geen significant onderscheid tussen $\mathrm{vg}, \mathrm{ba} / \mathrm{vg}$ en ba. De verschillen in deze taakopvattingsvariabelen lopen door de 3 categorieën artsen heen. 


\section{RESULTATEN}

\section{$5.1 \quad$ Inleiding}

Dit hoofdstuk bevat de beschrijving wan de analyse en analyseresultaten ten aanzien van de arts- en patiëntgebonden factoren, die de verschillen in arbeidsongeschiktheidsduur kunnen verklaren. Deze factoren kumnen gelegen zijn in de persoon en werk(omgeving) van arts. Omdat ook een aantal patientaspecten als aard van het werk, leeftijd, opleidingsniveau en ernst van de aandoening van invloed kunnen zijn op de ao-duur, zij hiervoor bij het onderzoek naar de relatie tussen ao-duur en de verzekeringsgeneeskundige begeleiding deze patiënt-variabelen als controle-variabelen meegenomen.

Hiermede wordt antwoord gegeven op de probleemstellingen $3 \mathrm{a}$ en $3 \mathrm{~b}$ :

3a. Zijn de verschillen in arbeidsongeschiktheidsduur afhankelijk van de taakopvattingen en activiteiten van de $\mathrm{vg}$ en ba/vg?

3b. Zijn de verschillen in ao-duur afhankelijk van de organisatorische context, waarbirmen de $v g$ en ba/vg werkzaam zijn?

Deze analyse is verricht voor de 2 categorieen artsen, die verzekeringsgeneeskunde in de dagelijkse praktijk beoefenen: de $v g$ en ba/vg.

Het verzekeringsgeneeskundig handelen wordt gemeten aan de hand van een registratie van de begeleiding van patiënten.

Onderstaand volgt een overzicht van de inhoud van dit hoofdstuk.

Paragraaf 5.2 geeft een beschrijving van de overeenkomsten en verschillen in de artsen- en patiëntenpopulaties.

Paragraaf 5.3 geeft een beschrijving van de verschillen in begelleiding tussen $\mathrm{vg}$ en $\mathrm{ba} / \mathrm{wg}$.

Paragraaf 5.4 geeft een beschrijving van de analysemethode en de analyseresultaten in arbeidsongeschiktheidsduren (ao-duren), de verschillen en overeenkomsten, alsook factoren die invloed hebben op de ao-duur.

Paragraaf 5.5 geeft de resultaten weer met discussie en toelichting. Hiermede wordt antwoord gegeven op de probleemstellingen $3 \mathrm{a}$ en $3 \mathrm{~b}$.

\subsection{Beschrijving van de artsen- en patiëntenpopulaties}

\subsubsection{Artsenpopulatie}

Aan de effectmeting nemen $21 \mathrm{vg}$ 'n en $14 \mathrm{ba} / \mathrm{kg}^{\prime} \mathrm{n}$ deel (zie ook tabel 3.2, pag. 51 ). De artsenpopulaties zijn onderzocht op persoons-, opleidings- en werkkenmerken. De artsenpopulaties $\mathrm{vg}$ en ba/vg vertonen, zoals in tabel 5.1 weergegeven, overeenkomst wat betreft de belangrijkste kenmerken als leeftijd, geslacht, jaar van afstuderen, da- 
tum indienstreding en de beschikbare werktijd. Daarentegen bestaan er verschillen: de ba/vg doet significant meer aan bij-en nascholing; de $\mathrm{vg}$ ziet wekelijks meer patiënten op het spreekuur.

Tabel 5.1 Kenmerken $* g(N=21)$ en ba/ $(\mathrm{wg}(\mathbb{N}=14)$

\begin{tabular}{|c|c|c|c|}
\hline Kenmerken & & $\mathrm{vg}$ & $\mathrm{ba} / \mathrm{kg}$ \\
\hline \multirow{2}{*}{ geboortejatar } & $\leq 1945$ & 7 & 6 \\
\hline & $>1945$ & 14 & 8 \\
\hline \multirow[t]{5}{*}{ aantul collega"s } & 0 & 3 & 2 \\
\hline & 1 & 0 & 5 \\
\hline & 2 & 3 & 1 \\
\hline & 3 & 4 & $\mathbb{1}$ \\
\hline & $\geq 4$ & 11 & 5 \\
\hline \multirow[t]{2}{*}{ gestacht } & $\operatorname{man}$ & 18 & 11 \\
\hline & vrous & 3 & 3 \\
\hline \multirow[t]{2}{*}{ jaar afstuderen } & $\leq 1975$ & 9 & 7 \\
\hline & $>1975$ & 12 & 7 \\
\hline \multirow[t]{2}{*}{ datum indiensttreding } & $\leq 1982$ & 14 & 10 \\
\hline & $>1982$ & 7 & 4 \\
\hline \multirow[t]{2}{*}{ besschikbutre werktijd } & voldoende & 15 & 10 \\
\hline & onvolloende & 6 & 4 \\
\hline mascholing en bij- & $\leq 3 \mathrm{~d} / \mathrm{j}$ & 14 & $3 * * *$ \\
\hline scholing & $>3 \mathrm{~d} / \mathrm{j}$ & 7 & 11 \\
\hline wantal patiënten & $\leq 40$ & 3 & 7 .*k \\
\hline per week & $>40$ & 18 & 7 \\
\hline
\end{tabular}

* $\quad p \leq 0.01$

$0.01<p \leq 0.05$

\subsubsection{Patiëntenpopulatie}

Het handelen van de $\mathrm{vg}$ en ba/vg is gevolgd aan de hand van een registratie (door de $\mathrm{vg}$ of ba/vg) van de oordeelsvorming en geplande activiteiten met behulp van de vgvragenlijst (zie paragraaf 3.3 .3 , pag. 59). Om onderzoek te kunnen doen naar de factoren, die verband houden met de ao-duur, moet de ao-duur per patiënt bekend te zijn. De eerste arbeidsongeschiktheidsdag wordt door de vg of ba/vg ingevuld op de zogenaamde patiënt-artsvragenlijst. De laatste ao-dag wordt vermeld op hetzij de vg-vragenlijst, als de patiënt op advies van of in overleg met de $\mathrm{vg}$ of $\mathrm{ba} / \mathrm{vg}$ het werk hervat, hetzij de eindlijst, als de patiënt zelf besluit tot werkhervatting. Dit betekent, dat alleen 
die patiënten in het onderzoek betrokken zijn, waarvan een ingevulde patiënt-artsvragenlijst én de bijbehorende vg-vragenlijst of eindlijst ontvangen zijn.

Bij de opzet van het onderzoek is uitgegaan van het registreren van de begeleiding van 495 patiënten. In werkelijkheid echter zijn gegevens over 489 patiënten ontvangen, waarvan in 480 gevallen een patiënt-artsvragenlijst aanwezig is.

Ten behoeve van de analyses moeten van deze patiënten ook patiëntgegevens beschikbaar zijn. In totaal zijn de gegevens van 337 patiënten ontvangen (de zogenaamde patiëntvragenlijsten). Hieronder blijken 9 patiënten, waarvan geen patiënt-artsvragenlijst zijn ontvangen. Hierdoor kunnen 328 patiënten in het onderzoek meegenomen worden.

Er zijn 978 vg-vragenlijsten ontvangen; afhankelijk van het aantal beoordelingen zijn er één of meer vg-vragenlijsten per patiënt ingevuld. Van de hiervoor genoemde 328 patiënten zijn in totaal $959 \mathrm{vg}$-vragenlijsten ontvangen. 19 vragenlijsten betreffen patiënten, waarvan de patiënt-artswragenlijst en/of de patiënt-vragenlijst niet aanwezig is.

Er zijn in totaal 98 eindlijsten ontvangen; hiervan is in 7 gevallen de patiënt-artsvragenlijst en/of de patiënt vragenlijst niet aanwezig, zodat 91 lijsten in de analyses meegenomen kunnen worden. Deze eindlijst is alleen nodig in gevallen, waarin sprake is van een spontane werkhervatting, waarover de $\mathrm{vg}$ of $\mathrm{ba} / \mathrm{vg}$ niet op een andere wijze geïformeerd is.

Tabel 5.2 geeft een overzicht van het aantal ontvangen vragenlijsten naar soort lijst en, per soort lijst, de aanwezigheid van de patiënt-artsvragenlijst.

Tabel 5.2 Aantal ontvangen vragenlijsten

\begin{tabular}{l|r}
\hline aantal patiẻnten warover gegevens ontwangen & 489 \\
aantal patiëntem met patiënt-artsvragenlijst & 480 \\
aantal patiënten met patiënt-vragenlijst & 328 \\
aantal vg-vragenlijsten van deze patiënten & 959 \\
aantal eindlijsten van deze patiënten & 91 \\
\hline
\end{tabular}

Om de begeleiding van de 480 patiënten te kunnen volgen, zijn de 978 vg-vragenlijsten, zoals weergegeven in tabel 5.3 geordend naar:

a. le vg-vragenlijsten; dit zijn de vragenlijsten die ingevuld zijn bij de le spreekuturbeoordeling na selectie. In totaal zijn 482 le vg-vragenlijsten ontvangen; dit komt in hoge mate overeen met het aantal geselecteerde patiënten (480). Van 2 patiënten bleken geen andere gegevens beschikbaar te zijn. Vermoedelijke is per buis door de arts een vg-vragenlijst ingevuld.

b. de laatste vg-vragenlijsten (233); deze lijsten bevatten de beoordelingstesultaten van de spreekuur(su-)beoordeling, waarna de begeleiding op initiatief van de $\mathrm{vg}$ of $\mathrm{ba} / \mathrm{vg}$ wordt stopgezet, bijv. door een hersteldverklaring. Is de initiatiefnemer van de beëindiging niet de $\mathrm{vg}$ of ba/vg, maar bijv. de patiënt in geval van een spontane werkhervatting, dan werd de reden van beëindiging weergegeven op de zogenaamde eindlijst, waarvan er in totaal 98 zijn ontvangen. 
c. de overige wg-vragenlijsten (263); in deze vg-vragenlijsten zijn de beoordelingresultaten van de tussentijdse (niet eerste, niet latste beoordelingen) weergegeven.

Voor het onderzoek naar de verschillen in oordeelsvorming en begeleiding tussen $\mathrm{vg}$ en ba/vg zijn met name de eerste en laatste vg vragenlijsten van belang.

Tabel 5.3 laat zien, dat de ba/vg relatief meer su-beoordelingen verricht nà de cerste su-beoordeling dan de $\mathrm{vg}$.

Tabel 5.3. Vy-qragenlijsten naar eerste, laatste en overig, per calegorie arts

\begin{tabular}{l|cr|c}
\hline vguragenlijgt & & categorie arts & totaal \\
& $v g$ & $b a / v g$ & \\
\hline le vg-vragenilijst & 406 & 76 & 482 \\
overige vg-vragenlijst & 211 & 52 & 263 \\
laattste vg-vragenlijst & 184 & 49 & 233 \\
\hline Total & 801 & 177 & 978 \\
\hline
\end{tabular}

Zoals hiervoor beschreven zijn van de 480 geselecteerde patiënten in totaal 337 patiënt-vragenlijsten ontvangen: een non-respons van $30 \%$. Dit kan gelegen hebben aan de onderzoeksprocedure en/of de patiënt. Bij de uitvoering van het onderzoek zijn vele personen betrokken: medewerk(st)ers van de administratie van de deelnemende instellingen, die belast waren met de selectie van patiënten, en de artsen, die aan de geselecteerde patiènten de patiënt-vragenlijsten moesten uitreiken. Het is ondanks de bewaking van de selectieprocedure mogelijk dat hier fouten zijn gemaakt. Vermoedelijk echter zijn vele patiënten na het eerste bezoek aan de arts hersteld verklaard zijn of hebben het werk na het eerste spreekuurbezoek spontaan hebben hervat. Waarschijnlijk hebben zij daarom afgezien van het invullen en insturen van de patiënt-vragenlijst. Dit kan betekenen dat er een relatie is tussen de non-respondenten en de korte duur van hun arbeidsongeschiktheid. Hierop wordt in paragraaf 5.3.2 nader ingegaan.

Tenslotte is het mogelijk dat patiènten hebben afgezien van het verstrekken van gegevens uit angst voor onjuist gebruik, ook al ontvingen zij een schriftelijke garantie, welke onjuist gebruik uitsloot.

Wat de non-respondenten betreft is tevens nagegaan in welke mate non-respondenten voorkomen bij de vg en ba/vg. Onder non-respondenten verstaan we patiënten, die geselecteerd zijn en waarvan een patiënt-arts vragenlijst is ingevuld, maar waarvan de (door de patiënt zelf in te vullen) patiënt-vragenlijst niet is ontvangen. In tabel 5.4. is de verdeling over $\mathrm{vg}$ en ba/vg weergegeven van de totaal geselecteerde 480-populatie en de 143 non-respondenten van de 480-populatie. Wat de 480-populatie betreft konden de ontvangen gegevens door het ontbreken van gegevens over de arts in 14 gevallen niet herleid worden tot de categorie arts: $\mathrm{vg}$ of ba/vg.

Het aantal non-respondenten van de vg is hoger dan het aantal non-respondenten van de $b a / v g$. 
Tabell 5.4 Non-respondenten 480-populatie: verdeling naar vg en ba/vg

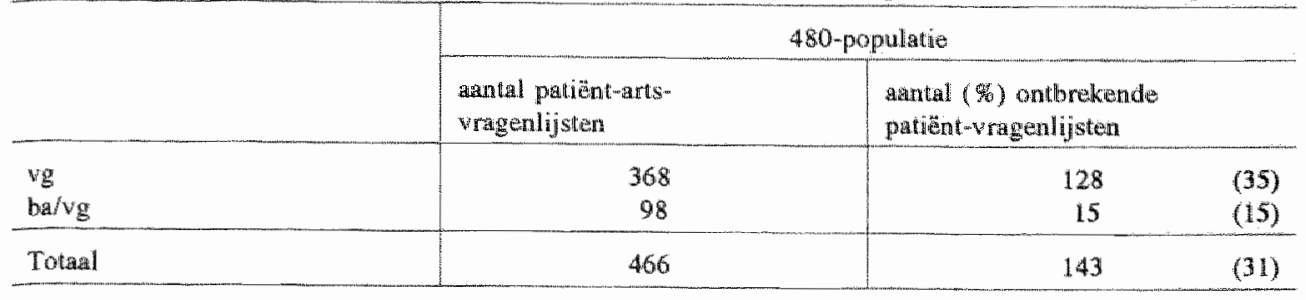

Het meest aantrekkelijke is de analyse uit te voeren op de grootst mogelijke patiëntenpopulatie: de 480-populatie. Zoals hiervoor al aangegeven, is het voor de berekening van de verzuimduur noodzakelijk te beschikken over zowel de patiënt-artsvragenlijst als de patiëntvragenlijst. De patiëntvragenlijst is tevens onontbeerlijk bij de analyse van de samenhang tussen de ao-duur en patiëntkenmerken. De noodzaak te beschikken over de combinatie van patiënt-artsvragenlijst en patiëntvragenlijst beperkt het aantal in de anllyse te betrekken patiënten tot 328. Passen we op deze populatie het leeftijdscriterium toe (geboren tussen/in 1946 en 1966), dan blijken 13 patiënten hieraan niet te voldoen. Van de grootst mogelijke patiëntenpopulatie blijven derhalve 315-patiënten beschikbaar ten behoeve van het onderzoek.

Tabel 5.5 Samenstelling patiëntenpopulatie volgens selectie criteria aan de hand wan het alantal ontvangen wragenlijsten

\begin{tabular}{l|c}
\hline selectiecriteria & aantal patiënten \\
\hline $\begin{array}{l}\text { total aantal ontvangen patiërnt-artsvragen- } \\
\text { lijsten }\end{array}$ & 480 \\
$\begin{array}{l}\text { aantal patiënt-artsv ragenlijst met bijbehorende } \\
\text { patiënt-vragenlijst } \\
\text { geboren tussen/in } 1946 \text { en } 1966\end{array}$ & 328 \\
\hline
\end{tabular}

$\mathrm{Bij}$ het onderzoek naar de samenhang tussen ao-duur en onafhankelijke variabelen met behulp van de multiple regressie-analyse (par. 5.4) kunnen alleen patiënten betrokken worden, waarvan de ao-duur bekend is; dat will zeggen er moet een patiënt-artsyragenlijst zijn, waarin de eerste ao-dag vermeld is en er moet een laatste vg-vragenlijst of eindlijst zijn, waarin de laatste ao-dag vermeld is. Er zijn in totaal 233 laatste vg-vragenlijsten (tabel 5.3) en 91 eindlijsten (tabel 5.2) ontvangen; daar niet in alle gevallen de laatste ao-dag is vermeld, is de omvang van de onderzoekspopulatie bij de analyse van de samenhang tussen ao-duur en onafhankelijke variabelen kleiner dan $315 \mathrm{en}$ varieert, afhankelijk van de diagnosegroep, van 44 (diagnosegroep psychische ziekten) tot 206 (alle diagnosegroepen). 


\subsubsection{Kenmerken van de onderzoekspopulaties}

De in paragraaf 5.2 .2 beschreven onderzoekspopulatie is onderzocht op persoons-, opleidings-en werkkenmerken.

Tabe 5.6 Kenmerken van de onderzoelspopulatie patienten (N $=315$ )

\begin{tabular}{|c|c|c|c|c|}
\hline \multirow[t]{2}{*}{ Patientkenmerken } & & \multicolumn{3}{|c|}{$\begin{array}{c}\text { onderwoekspop. } \\
\qquad \begin{array}{c}N=315 \\
\end{array}\end{array}$} \\
\hline & & $\mathrm{vg}$ & $\mathrm{ba} / \mathrm{vg}$ & \\
\hline \multirow[t]{2}{*}{ geboortedatum } & $1945 \mathrm{~d} / \mathrm{m} \quad 1956$ & 135 & 40 & $*$ \\
\hline & $1957 \mathrm{t} / \mathrm{m} 1966$ & 121 & 19 & \\
\hline \multirow[t]{2}{*}{ geslacht } & man & 157 & 45 & $*$ *** \\
\hline & vrohis & 98 & 14 & \\
\hline \multirow[t]{2}{*}{ butgerlinke start } & gehuwd & 178 & 46 & \\
\hline & ongehuwd & 7.4 & 12 & \\
\hline \multirow[t]{2}{*}{ oplerdingsmiveru } & $\leq \mathrm{MAVO}$ & 185 & 28 & 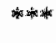 \\
\hline & $\geq \mathrm{MBO}$ & 71 & 31 & \\
\hline \multirow[t]{2}{*}{ diensten } & dagdienst & 187 & 37 & \\
\hline & wisseldienst & 61 & 21 & \\
\hline \multirow[t]{2}{*}{ datum indiensttreding } & $\leq 1985$ & 61 & 7 & $*$ \\
\hline & $>1985$ & 181 & 49 & \\
\hline
\end{tabular}

* $\quad p \leq 0.01$

$0.01<\mathrm{p} \leq 0.05$

* $0.05<\mathrm{p} \leq 0.10$

Tabel 5.6 bevat een overzicht van de meest relevante patiëntkenmerken van de onderzoekspopulatie.

De onderzoekspopulatie toont significante verschillen tussen $\mathrm{vg}$ en ba/vg; deze verschillen betreffen de leeftijd, het geslacht, het opleidingsniveau en de duur van het dienstverband van de patiënten.

De onderzoekspopulatie van de $\mathrm{vg}$ is relatief jonger, bestaat uit meer vrouwen, heeft een relatief laag opleidingsniveau en kenmerkt zich door een relatief. lang dienstverband.

\subsection{Verschillen in begeleiding tussen verzekeringsgeneeskundige en bedrijlsarts/verzekeringsgeneeskundige}

In deze paragraaf zullen de verschillen in begeleiding tussen $\mathrm{vg}$ en ba/vg in kaart worden gebracht. Achtereenvolgens zal worden ingegaan op de verschillen in ao-duur van 
de vg- en ba/vg-popullatie (par. 5.3.1), de verschillen in begeleidingsactiviteit (par. 5.3.2) en de verschillen in oordeelsvorming (par. 5.3.3).

De gegevens worden ontleend aan de patiënt-artswragenlijst en de eerste $\mathrm{vg}$-vragenlijst. We hoeven ons bij deze analyse niet te beperken tot de onderzoekspopulatie, maar kunnen de 480-populatie als uitgangspunt nemen. Per onderzoeksitem kan het aantal patiënten verschillen ten gevolge van missings door onvolledige of ontbrekende invulling van rubrieken.

\subsubsection{Verschillen in arbeidsongeschiktheidsduur}

De voor de hand liggende vraag is: zijn er verschillen in ao-duur tussen de door de vg en ba/vg begeleide patiënten. Uitgaande van de ontvangen patiënt-artsvragenlijsten (480) en le vg-vragenlijsten (482) - zie paragraaf 5.2.2 - is de ao-duur berekend van alle patiënten, die uiteindelijk in het eigen werk hervat hebben $(N=433)$. Vervolgens zijn de patiënten verdeeld naar ao-duurklassen en, zoals weergegeven in figuur 11 , in een percentage van de totale patiëntenpopulatie per $\mathrm{vg}$ of ba/vg weergegeven.
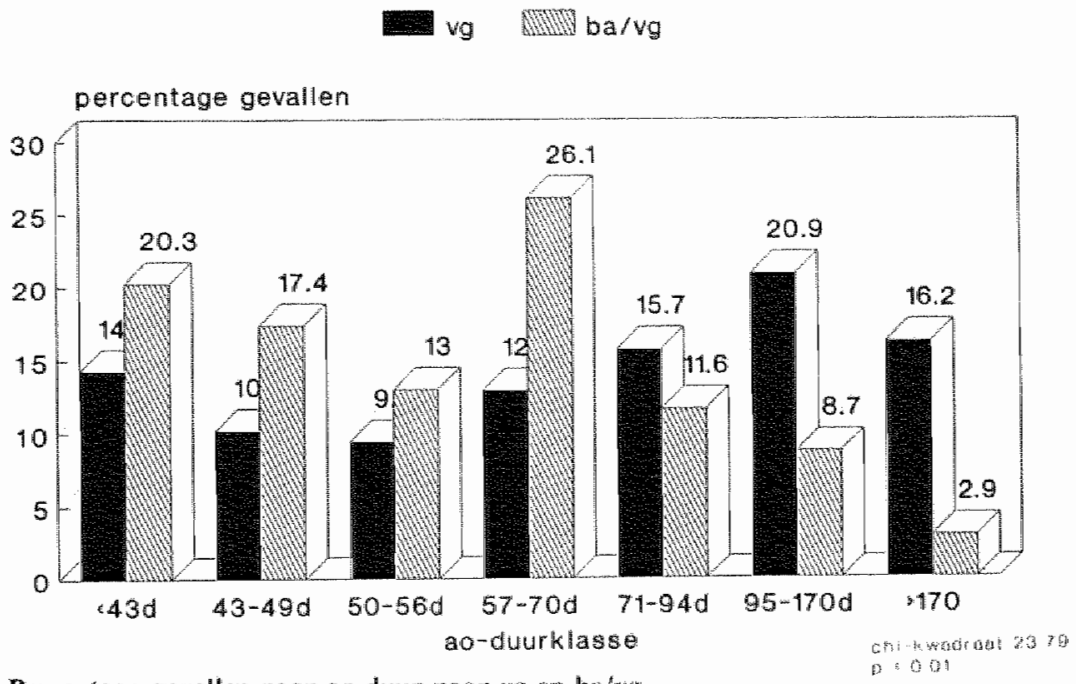

Figuur 11 Percentage gevallen naar ao-duur naar wg en ha/vg

Het meest opvallend is het hoge percentage door de ba/vg begeleide patiënten in de duurklassen $t / \mathrm{m}$ 57-70 dagen met de forse piek in de duurklasse 57-70 dagen versus het hoge percentage door de $\mathrm{vg}$ begeleide patiënten in de duurklassen 71-94 dagen en hoger.

De door de $v g$ begeleide patiënten lijken een grotere kans op een lange ao-duur te hebben dan de door de ba/vg begeleide patiënten.

De vraag is, of hier sprake is van een echt of artificiee] verschil bijvoorbeeld op grond van verschillen in begeleide populaties of op grond van verschillen in wachttijd (de periode tussen 1e ao-dag en le spreekuurbeoordeling). 
In paragraf 5.3 .2 zullen de verschillen in begeleidingsactiviteit (wachtijd, aantal spreekuurbeoordelingen) besproken worden. De oordeelsvorming van de $\mathrm{vg}$ en ba/vg (diagnose, begeleidingsplan) komen in paragraf 5.3 .3 aan bod.

\subsubsection{Verschillen in begeleidingsactiviteit}

De voor de handliggende vraag is op welk moment, gerekend vanaf de le ao-dag, de vg en ba/vg de begeleiding start: wanneer ziet de arts de patiënt voor de eerste maal op het spreekutr? Wij noemen de periode tussen de le ao-dag en de eerste su-beoordeling de wachtijd.

De registratie van de su-beoordeling start echter in de $4 \mathrm{e}$ tot $9 \mathrm{e}$ arbeidsongeschiktheidsweek. De vraag rijst of de, op basis van de eerste geregistreende beoordeling berekende, wachtrijd de werkelijke wachttijd is; of anders gezegd, heeft de arts de patient mogelijk al wór de $4 \mathrm{e}$ week gezien? Hoewel dit inderdaad niet geheel is uit te sluiten, mag er op grond van de regelgeving van de verschillende instellingen en uitvoeringsorganisaties van uit worden gegaan dat beoordelingen vór de 4 e ao-week eerder uitzondering dan regel zijn. Dit wordt mede bepaald door de inschakeling van leken gedurende de eerste weken (onder andere GAK: rapporteurs ziektewet), het inschakelen wan huisartsen gedurende maximal de eerste 3 maanden (BVG) of ingeslepen gewoonten: het toekennen van een grote verantwoordelijk van de patiënt gedurende de eerste verzuimweken (DGD, PTT). Dit laatste wijkt soms af van de formele regelgeving binnen de organisatie, die een snellere le beoordeling voorschrijft. De op basis van de le subeoordeling berekende wachttijd zal dan ook in hoge mate overeenkomen met de werkelijke wachtijid. Hierop wijzen ook de verschillen in moment van le su-beoordeling, die al bij een ao-duur van 4 weken waameembaar zijn. Vanaf het moment van de start van de registratie is er, zoals tabel 5.7 laat zien, een significant verschil. De ba/vg ziet $\mathrm{t} / \mathrm{m}$ de $7 \mathrm{e}$ ao-week de patiënten sneller. De $\mathrm{vg}$ daarentegen ziet een relatief groot aantal patiënten voor de eerste maal na de 7 e ao-week.

Het aantal non-respondenten (zie par. 5.2.2.) vormt geen verstorende factor; elke subgroep is in voldoende mate vertegenwoordigd.

Tabel 5.7 Anntal patiènten per tijdstip wan hun exste contact met yg of ba/vg (N $=480 ;$ migsing 21$)$

\begin{tabular}{|c|c|c|c|c|c|c|c|c|}
\hline \multicolumn{2}{|c|}{ wo-dager } & $\leq 28$ & $29-35$ & $36-42$ & $43-49$ & $50-56$ & $>56$ & totaal \\
\hline \multirow[t]{2}{*}{$v_{g}$} & $\mathbb{N}$ & 20 & 79 & 72 & 60 & 49 & 104 & 384 \\
\hline & $\%$ & 5 & 21 & 19 & 16 & 13 & 27 & 84 \\
\hline \multirow[t]{2}{*}{$\mathrm{bat} / \mathrm{gg}$} & $\mathbb{N}$ & 5 & 17 & 21 & 18 & 8 & 6 & 75 \\
\hline & $\%$ & 7 & 23 & 28 & 24 & 11 & 8 & 16 \\
\hline \multicolumn{2}{|l|}{ Totoul } & 25 & 96 & 93 & 78 & 57 & 110 & 459 \\
\hline
\end{tabular}

$p \leq 0.01$

$x^{2}=15,4$ 
Met name rijst de vraag of de relatief "snelle" su-beoordeling door de ba/vg kan samenhangen met een vroegtijdige inschatting van de vermoedelijke ao-duur van de patiënt. Of anders gezegd: ziet de ba/vg ook patiënten in de verschillende ao-duurklassen sneller.

Om dit te onderzoeken zijn de patiënten verdeeld in duurklassen op basis van de aoduur (verschil tussen hervattingsdatum en le ao-dag); deze ao-duurklassepopulaties zijn, zoals in tabel 5.7 weergegeven, onderzocht op het aantal beoordelingen (én of meer) van de $\mathrm{vg}$ en ba/vg (tabel 5.8).

Tabel 5.8 Aantal (\%) gevallen met een en 2 of meer beoorddingen per duurklassen natr vg en ba/wg $(N=480$; missing 47)

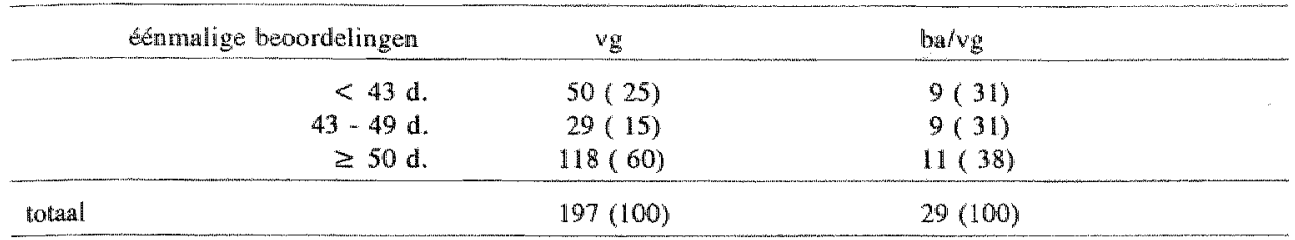

$p \leq 0.04 \quad x^{2}=6.45$

\begin{tabular}{rrrr} 
aantal beoordelingen $\geq 2$ & $v g$ & balwg \\
\hline & $<49 \mathrm{~d}$ & $10(6)$ & $8(20)$ \\
$50-70 \mathrm{~d}$. & $22(13)$ & $16(40)$ \\
& $71-94 \mathrm{~d}$. & $40(24)$ & $8(20)$ \\
& $\geq 94 \mathrm{~d}$. & $95(57)$ & $8(20)$ \\
\hline totaal & & $167(100)$ & $40(100)$ \\
\hline
\end{tabular}

$p \leq 0.01 \quad x^{2}=28.98$

Wat direct opvalt, is het grote aantal énmalige beoordelingen door de vg in alle duurklassen; in de duurklassen boven 70 dagen heeft de ba/vg alle patiënten meer dan éenmaal gezien op het spreekuur; de vg heeft van de patiënten, die meer dan 70 dagen hebben verzuimd, ruim $25 \%$ slechts énmalig op het spreekuur gezien. In figuur 12 is het percentage éénmalige su-beoordelingen per duurklasse naar $\mathrm{vg}$ en ba/vg weergegeven.

Samenvattend blijkt de $\mathrm{vg}$ in de eerste 2 maanden van de arbeidsongeschiktheid minder snel tot een spreekuurbeoordeling te komen dan de ba/vg. Het aantal patiënten, dat slechts énmalig op het vg-spreekuur is gezien, is met name in de duurklassen boven de 70 dagen relatief hoog; daarentegen, de ba/vg-populatie met een ao-duur $>70$ dagen blijkt in alle gevallen minimaal 2 maal op het spreekuur beoordeeld te zijn. 


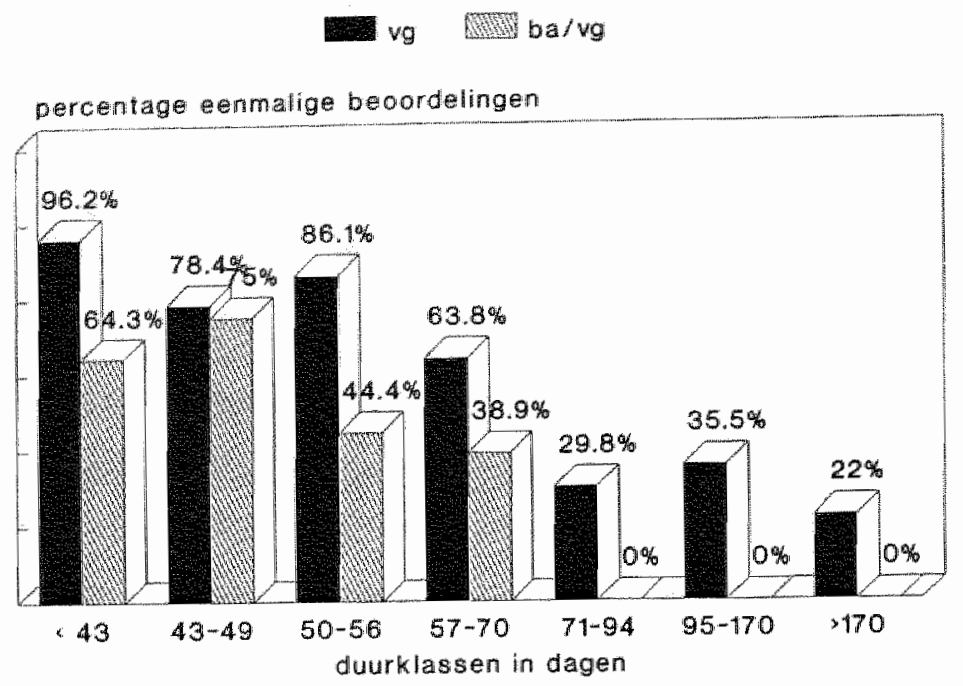

Figuur 12 Percentage eenmalige beoordelingen per a0-duurklasse, vg en ba/vg

\subsubsection{Verschillen in oordeelsvorming}

In deze paragraaf zullen we het beoordelingsproces van de $\mathrm{vg}$ en ba/vg beschrijven aan de hand van de bij eerste en laatste beoordeling gestelde diagnosen, aangegeven begeleidingsplannen, de verzekeringsgeneeskundige conclusie, de prognose met betrekking tot de eindsituatie en de mate waarin huisarts en specialist door de patiënt geraadpleegd zijn. De tabellen $5.9 \mathrm{t} / \mathrm{m} 5.13$ geven een overzicht van de verschillen in beoordeling tussen vg en ba/vg bij do eerste en laatste spreekuurbeoordeling. Zoals al aangegeven bij de inleiding van paragraaf 5.3 zijn deze analyses uitgevoerd op de 480-populatie. Door ontbrekende of onvolledige invulling van de verschillende rubrieken van de vragenlijsten treden er verschillen op in het aantal patiënten per beoordelingselement. In bijlage 6 zijn de statistische kenmerken van de geregistreerde beoordelingselementen opgenomen.

\section{De diagnose}

Alle door de vg en ba/vg gestelde hoofddiagnosen zijn door de vg en ba/vg gecodeerd volgens de zogenaamde ziekte- en ongevalscodering, zoals uitgegeven door de Federathe van Bedrijfsverenigingen (FVB). Deze diagnosecodering is gebaseerd op de International Classification of Diseases (ICD), 9th edition, 1975. De ziekte- en ongevalscodering bevat de hoofdgroepen uit deze ICD voorzover zij wan belang zijn voor de verzekeringsgeneeskundige praktijk. Aan deze codering is door de FBV een (niet-ICD) codering van ongevallen en verwondingen/wergiftigingen toegevoegd. De toegekende 
diagnosen (zie voor een volledig overzicht van de gebruikte diagnosen: bijlage 5) zijn samengevoegd tot diagnosegroepen:

psychische ziekten:

ziekten van het hart- en vaatstelsel:

ziekten van de ademhalingswegen:

ziekten van het bewegingsstelsel:

ongevallen:

overige diagnosen:
$0.290 \mathrm{t} / \mathrm{m} 0.318$

$0.390 \mathrm{t} / \mathrm{m} 0.459$

$0.462 \mathrm{t} / \mathrm{m} 0.519$

$0.710 \mathrm{t} / \mathrm{m} 0.736$

$1.803 \mathrm{v} / \mathrm{m} 9.995$

alle overige diagnosecodes.

Wat betreft de toegekende diagnosegroepen bestaat er geen significant verschil in de verdeling van de gevallen over vg en ba/vg. Dit geldt zowel voor de le als laatste subeoordeling. Verschillen in ao-duur tussen de door vg en ba/vg verzorgde populatie berusten niet op verschillen in gestelde diagnosen (tabel 5.9).

Tabel 5.9 Verschillen in beoordeling on en ba/kg bij le en laatste spreekuurbeoondeling in $\%$ van de totale populatie: diagnosegroepen

\begin{tabular}{l|cc|cc}
\hline & \multicolumn{2}{|c|}{ le beoordeling } & \multicolumn{2}{|c}{ laatste beoordeling } \\
& $\mathrm{vg}$ & $\mathrm{ba} / \mathrm{vg}$ & $\mathrm{vg}$ & $\mathrm{ba} / \mathrm{vg}$ \\
\hline Diagnosegroepen: & $\mathrm{N}=392$ & $\mathrm{~N}=76$ & $\mathrm{~N}=179$ & $\mathrm{~N}=49$ \\
psychische ziekten & 25 & 25 & 28 & 25 \\
ziekte wan het circulatie-apparaat & 2 & 5 & 2 & 4 \\
ziekte van de adlemhal ingswegen & 3 & 3 & 5 & 2 \\
ziekte van het bewegingsapparaat & 36 & 33 & 37 & 35 \\
ongevallen & 11 & 11 & 6 & 8 \\
overig & 23 & 24 & 22 & 27 \\
\hline
\end{tabular}

\section{Het begeleidingsplan}

Het begeleidingsplan geeft de voorgenomen activiteiten aan, welke de $\mathrm{vg}$ of ba/vg zal ondernemen in het kader van de reïntegratie van de patiënt. Dit kan bestaan uit: louter afwachten, inschakeling en/of beïnvloeding van de curatieve sector, contacten met werkgever $\mathrm{t} / \mathrm{m}$ thet overdragen van de begeleiding aan GMD of het advies vragen aan het $A B P$. In de praktijk blijken artsen vaak verschillende begeleidingsacties tegelijk te plannen, bijw. overleg met de huisarts en overleg met de werkgever. Daaron konden de $\mathrm{vg}$ en ba/vg met betrekking tot het begeleidingsplan kiezen tot maximaal drie alternatieven. Indien men méer dan 1 alternatief gekozen heeft, is deze gerubriceerd onder het alternatief, dat de meest verregaande verzekeringsgeneeskundige activiteit vraagt.

Met betrekking tot de activiteiten die de $\mathrm{vg}$ of ba/vg voomemens is te ondernemen naar aanleiding van hetzij de le hetzij de laatste su-beoordeling bestaan significante verschillen (tabel 5.10). Beperken we ons allereerst tot de le su-beoordeling, dan zien we dat de $\mathrm{vg}$ in ruim $77 \%$ van de gevallen geen begeleidingsactiviteiten ontplooit: de patiënt wordt hersteld verklaard of men wacht de medische eindtoestand af. 


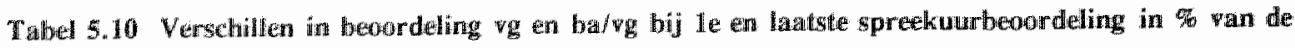
totalk populatie: begeleidingsplan

\begin{tabular}{|c|c|c|c|c|}
\hline & \multicolumn{2}{|c|}{ Ie beowrdeling } & \multicolumn{2}{|c|}{ lakatste beoordeling } \\
\hline & $v g$ & bakg & $v g$ & $\mathrm{ba} / \mathrm{vg}_{\mathrm{g}}$ \\
\hline Begeleidingsplan: & $\mathbb{N}=390$ & $N=76$ & $N=177$ & $N=49$ \\
\hline hersteld verklaren & 36 & 18 & 52 & 33 \\
\hline wathen op med. endroestand & 41 & 30 & 26 & 22 \\
\hline insthaling med. specialist & 7 & 1 & 4 & 0 \\
\hline beinvloeding cur. sector & 3 & 13 & 2 & 12 \\
\hline overleg wg: lijdelijke matatr. & 2 & 25 & 2 & 20 \\
\hline overleg wg: blijvende maatr. & $\mathbb{1}$ & 5 & 1 & 6 \\
\hline inschakelling $G M D$ of $A B P$ & 10 & 7 & 14 & 6 \\
\hline
\end{tabular}

$$
p \leq 0.01 \quad p \leq 0.01
$$

De balvg, die zich overigens in bijna $50 \%$ van de gevallen in feite afwachtend opstelt, is in rum $13 \%$ van de gevallen van plan invloed te gaan uitoefenen op de door de curatieve sector ingestelde therapieën; de vg slechts in een kleine $3 \%$. In $30 \%$ van de gevallen plant de ba/vg contact met de werkgever over maatregelen van tijdelijke of blijvende aard, welke de reintegratie naar verwachting zullen bespoedigen. De vg daarentegen slechts in $3,1 \%$ van de gevallen. De $\mathrm{vg}$ is overigens vijfmaal vaker van plan een medisch specialist te raadplegen dan de ba/vg.

Het door de $\mathrm{vg}$ en ba/vg bij de laatste su-beoordeling aangegeven begeleidingsplan komen overeen. De $v g$ is bij de laatste su-beoordeling vaker van plan de GMD te raadplegen dan bij de eerste su-beoordeling.

Samengevat: de $\mathrm{vg}$ is, wat betreft de geplande begeleidingsactiviteiten per patiënt, minder actief dan de ba/vg. Hierbij moet wel opgemerkt worden dat de afstand tussen $\mathrm{vg}$ en bedrijf groter is dan bij de ba/vg, de reintegratiemogelijkheden daarentegen kleiner zijn (veel kleine bedrijven), de vg de patiënten gemiddeld later op het spreekuur ziet en het aantal door de vg op het spreekuur beoordeelde patiènten in vergelijking met de ba/vg significant groter is (tabel 5.8). De $\mathrm{vg}$ is over het geheel minder actief ten aanzien van de individuele werknemer.

\section{De vertekeringsgeneeskundige conclusie}

De verzekeringsgeneeskundige conclusie bevat het eindoordeel van de $\mathrm{vg}$ en ba/vg na een su-beoordeling. Deze conclusies zijn vervat in termen van ziekte en beperkingen. De conclusies lopen van "geen ziekte, geen beperkingen (dus arbeidsgeschikt) lot "blijvende beperkingen, prognose voor alle arbeid infaust".

De vragenlijst bevat een 8 al conclusies. Deze 8 conclusies zijn limitatief, dat wil zeggen andere dan de aangegeven conchusies zijn niet mogelijk. De conclusies 7 en 8 (mu arbeidsongeschikt, prognose onbekend cq. prognose infaust) zijn samengevoegd. Ten aanzien van de conclusies bij le su-beoordeling kon geen significant verschil tus- 
sen vg en ba/vg worden waargenomen (tabel 5.11). Dit geldt niet voor de conclusies bij de laatste su-beoordeling. Kijken we wat de $\mathrm{vg}$ betreft naar het verschil tussen de le en laatste beoordeling, dan valt op dat de $\mathrm{vg}$ bij de laatste beoordeling optimistischer is ten aanzien van het aantal geen ziekte en/of geen beperkingen en arbeidsgeschiktheid te zijnertijd, maar toch een relatief groot aantal patiënten niet meer in het arbeidsproces ziet tenugkeren.

Het percentage: prognose onbekend", van de vg daalt van $9 \%$ bij de eerste spreekuurbeoordeling naar $3 \%$ bij de laatste spreekuurbeoordeling; bij de ba/vg is deze daling vrijwel afwezig: van $5 \%$ naar $4 \%$. Het oordeel van de vg bij de laatste su-beoordeling is in vergelijking met de le beoordeling gedifferentiëerder.

Tabel 5.11. Verschillen in beoordeling $\mathrm{rg}$ en ba/vg bij $1 \mathrm{e}$ en laatste spreekuurbeoordeling in $\%$ van de totale populatie: conclusie

\begin{tabular}{|c|c|c|c|c|}
\hline & \multicolumn{2}{|c|}{ le beoordeling } & \multicolumn{2}{|c|}{ laatste beoordeling } \\
\hline & $v g$ & $\mathrm{ba} / \mathrm{vg}$ & $\mathrm{vg}$ & $\mathrm{bat} / \mathrm{g}$ \\
\hline Conchusie: & $N=380$ & $\mathbb{N}=76$ & $\mathrm{~N}=173$ & $\mathbb{N}=49$ \\
\hline geen ziekte/geen beperkingen & 12 & 11 & 25 & 20 \\
\hline wel ziekte/geen beperking & 6 & 9 & 10 & 4 \\
\hline geen ziekte/wel beperking & 5 & 12 & 4 & 14 \\
\hline nu so, geneest zonder beperk. & 61 & 55 & 42 & 49 \\
\hline rus ao, zall beperkingen houden, well ti.z.t. & & & & \\
\hline geschikt & 5 & 3 & 9 & 4 \\
\hline nu a, niet meer geschilkt & 3 & 5 & 8 & 4 \\
\hline nu ao, prognose onbekend & 9 & 5 & 3 & 4 \\
\hline
\end{tabular}

* voor thet eigen werk

$$
p=0.07
$$

\section{De prognose ten aanzien wan de eindsituatie}

Bij iedere su-beoordeling is de $\mathrm{vg}$ en ba/vg gevraagd wat de prognose is wat betreft werkhervatting. De $\mathrm{vg}$ of $\mathrm{ba} / \mathrm{vg}$ moet $\mathrm{zijn} / \mathrm{haar}$ verwachting aangegeven: volledige werkhervatting te verwachten bij eigen of andere werkgever, gedeeltelijke werkhervatting te verwachten bij eigen of andere werkgever, zal nog uitsluitend kunnen werken als arbeidstherapie (geen verdiencapaciteit) bij eigen of andere werkgever, of zal niet meer kunnen werken.

Wat de prognose na eerste su-beoordeling betreft bestaat er een significant verschil tussen de vg en ba/vg (tabel 5.12). Dit betreft vooral de mate waarin gedeeltelijk werken voorzien wordt; de ba/vg acht dit ruim 8 maal vaker waarschijnlijk dan de vg. De $\mathrm{vg}$ is bovendien somberder dan de ba/vg: bij eerste beoordeling acht de $\mathrm{vg}$ "niet meer werken" in ruim $7 \%$ van de gevallen waarschijnlijk; de ba/vg stelt deze prognose bij eerste beoordeling in geen enkele geval. Overigens is de vg wat optimistischer ten aanzien van de mogelijkheid van een volledige werkhervatting. 
Tabel 5.12 Venchullen in beoordeling we en ba/vg bij le en latste spreekurtbeoordeling in to wan we totalle populatie: prognose

\begin{tabular}{|c|c|c|c|c|}
\hline & \multicolumn{2}{|c|}{ le beoordeling } & \multicolumn{2}{|c|}{ laatste beoordeling } \\
\hline & $v g$ & $\mathrm{ba} / \mathrm{vg}$ & vg & bailvg \\
\hline Pragnose: & $N=296$ & $\mathbb{N}=60$ & $\mathrm{~N}=122$ & $N=32$ \\
\hline hervatting geheel in eigen of ander werk & 91 & 82 & 82 & 81 \\
\hline hervatting gedeeltelijk in eigen of ander werk & 2 & 17 & 17 & 9 \\
\hline werken als arbeidstherapie & 0 & 2 & 0 & 3 \\
\hline niet werken & 7 & 0 & 11 & 6 \\
\hline
\end{tabular}

$$
\mathrm{p} \leq 0.01
$$

Bij de latate su-beoordeling bestaan er geen significante verschillen meer tussen $\mathrm{vg}$ en $\mathrm{ba} / \mathrm{vg}$. De prognoses ten aanzien van volledige werkhervatting door vg en ba/vg zijn gelijk. De werschillen in prognose wat betreft gedeeltelik werken en niet meer werken zijn aanzienlijk kleiner. Het is aannemelijk dat het oordeel bij de laatste su-beoordeling dichter ligt bij de werkelijkheid dan bij de le su-beoordeling. Betekent dit dat de ba/vg zijn aanvankelijk optimisme laat varen? Waarschindijk niet. Vermoedelijk is deze waarneming het gevolg van grotere overeenkomst in patiëntenpopulatie wat de ernst en aard van de ziekte betreft. Daarnaast kunnen vg en ba/vg hun oordeel bij de laatste subeoordeling stoelen op vele voorgaande beoordelingen al of niet aangevuld met informatie van de curatieve sector en werkgever.

\section{Inschakeling curatieve sector}

Alvorens in te gaan op de verschillen tussen $\mathrm{vg}$ en ba/wg wat de mate betreft waarin huisarts en/of specialist geraadpleegd zijn, is het opvallend hoe vaak curatieve artsen door patiënten geraadpleegd zijn. Op grond van eerdere onderzoeken (onder andere Soeters, 1983) werden minder contacten tussen patiënten en curatieve artsen verwacht.

Ongetwijfeld speelt de selectie op ao-dwur hier een rol: hoe langer de ao-duur, hoe groter de kans op contact tussen patient en curatieve arts. Tussen de vg en ba/vg bestaan geen significante verschillen wat betreft de mate waarin huisarts en specialist door de patiënt geraadpleegd zijn, noch bij de eerste, noch bij de laatste spreekuur beoordeling (tabel 5.13). 


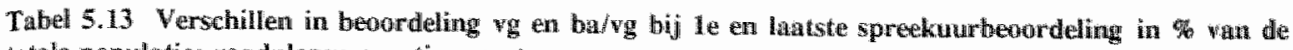
totale populatie: raadplegen curatiewe sector

\begin{tabular}{|c|c|c|c|c|c|}
\hline & \multicolumn{2}{|c|}{ le beoordeling } & \multicolumn{2}{|c|}{ laatste beoordoling } \\
\hline & & $\mathrm{vg}$ & batrg & $v g$ & balvg \\
\hline Curatieve sector: & & $\mathbb{N}=389$ & $\mathbb{N}=75$ & $N=163$ & $N=40$ \\
\hline \multirow[t]{4}{*}{ ha gertadpleegd. } & $\mathrm{ja}$ & 81 & 88 & 76 & 85 \\
\hline & neen & 14 & 11 & 18 & 5 \\
\hline & onbekend & 5 & 1 & 6 & 10 \\
\hline & & $\mathbb{N}=378$ & $N=72$ & $N=167$ & $N=43$ \\
\hline \multirow[t]{2}{*}{ specialist geraadpleegd } & ja & 55 & 66 & 66 & 70 \\
\hline & neen & 46 & 34 & 34 & 30 \\
\hline
\end{tabular}

\subsubsection{Samenvatting}

Zetten we de in de voorgaande paragrafen beschreven verschillen tussen $v \mathrm{~g}$ en ba/vg op een rij, dan ontstaat het volgende beeld:

Met betrekking tot de arbeidsongeschiktheidsduur: de door de vg begeleide patiëntenpopulatie heeft een grotere kans op langdurige ao-heid $(>70 \mathrm{~d}$.) dan de door de ba/vg verzorgde populatie. Als mogelijke verklaringen hiervoor kan gedacht worden aan verschillen in patientenpopulatie, activiteiten wan de arts, in relatie hiermee de regelgeving van de uitwoeringsorganisatie, en de grotere afstand tot het bedrijf.

De door de $v g$ verzorgde populatie is jonger, minder geschoold en bestaat uit relatief veel vrouwen (zie tabel 5.6). Bovendien ziet de vg de patiënten op een relatief laat tijdstip De vg-populatie heeft een grotere kans op langduriger verzuim (zie tabel 5.7). Hierbij spelen een aantal factoren een mogelijk verklarende rol.

Allereerst vormen de GAK-vg"n ongeveer $75 \%$ van de totale vg-populatie (zie tabel 3.1). De werkwijze van het GAK - de inschakeling van een niet-medicus/rapporteur ziektewet - kan leiden tot een late inschakeling van de $\mathrm{vg}$. De ba/vg beschikt weliswaar ook over de mogelikheid tot het inschakelen van genoemde rapporteurs, doch zal hiervan in de praktijk slechts incidenteel gebruik maken.

Het effect van deze werkwijze kan door het grote aantal GAK-vg"n de waarneming beinwloeden. Daarnaast betrekken $v g$ 'n hun patienten wit een zeer groot aantal bedrijwen. Deze bedrijven zullen vaak klein zijn en kenmerken zich door een lage organisatiegraad. De ba/ $/ \mathrm{g}$ daarentegen is veelal verbonden aan én of enige (tot tientallen) bedrijuen per ba/vg.

De afstand tussen bedrijf en $\mathrm{vg}$ is derhalve relatief groot, de informatie over het werk en werkomstandigheden is moelijker te vergaren en medewerking van de werkgever bij de reintegratie is val moeizaam te verkrijgen. Daarnaast zal de werkgever - ook voor hem immers is de afstand tot de vg veel groter dan die tot de ba/vg - minder en minder vaak druk op een snelle werkhervating kunnen uitoefenen. Kortom, zowel de 
vg als de werkgever van de door de vg begeleide patienten hebben minder wederzijdse informatie- en beinvloedingsmogelijkheden.

Het opleidingsniveau van de vg-patientenpopulatie is relatief hag: nim $60 \%$ van de patienten heeft maximaal een MAVO opleiding. Verwacht mag worden deze patienten relatief veel lichamelijk belastende arbeid verrichten, hetgeen allicht, samen met de geringe omvang van de bedrijven en de grotere afstand tot de bedrijven, een verlengend effect heeft op de ao duur van de door de $v g$ verzorgde populatie.

Met betrekking tot de begeleiding: de vg neemt in vergelijking met de ba/vg een afwachtende houding aan. Dit kan niet verklaard worden door meer interventies van de curatieve sector. De ba/vg richt de begeleidingsactiviteiten sterk op de werkgever cq. het bedrif: het trachten te realiseren wan tijdelijke of blijvende werkaanpassingen. De ba/vg ziet patiënten eerder en vaker dan de $\mathrm{wg}$. Na de $70 \mathrm{e}$ arbeidsongeschiktheidsdag zijn alle ba/vg-patiënten minimaal 2 maal op het su beoordeeld; de door de vg begeleide patienten hebben ook bij een ao-duur van meer dan 70 dagen hebben in ruim een kwart van de gevallen slecht énmaal het spreekuur bezocht. Ongetwijfeld speelt ook hier de regelgeving wan de uitvoeringsorganisatie en de geringere reintegratiemogelijkheden door het grote aantal (kleine) bedrijven een rol. In dit verband is het niet ondenkbaar, dat het moeten overdragen van de begeleiding aan de GMD bij blijvende aoheid, plaatsvindt op het moment dat de prognose zo helder mogelijk is. Het ontbreken wan reïtegratiemogelijkheden en de gedwongen overdracht van de begeleiding aan de GMD kunnen een verklaring zijn voor de geringere activiteit van de $v g$ en de relatief lange ao-duur. De 70e ao-dag lijkt een cruciale grens, zowel wat betreft de duur- als activiteitsverschillen tussen de $\mathrm{vg}$ en ba/vg.

Met betrekking tot de oordeelsworming: er bestaan significante verschillen wat betreft de conclusies/prognose tussen $\mathrm{vg}$ en ba/vg. De prognose van de ba/vg ten aanzien van werkhervatting is optmistischer dan die van de $\mathrm{vg}$. Overigens worden deze verschillen mussen de wat de prognose betreft optimistische ba/vg en de pessimistische $\mathrm{vg}$ door de tijd achterhaald: de prognose bij de laatste su-beoordeling toont geen significante verschillen meer.

In dit hoofdstuk zijn de verschillen in begeleiding van de $\mathrm{vg}$ en ba/vg in kaart gebracht en is, vooruitlopend op de bespreking van de analyseresultaten (par. 5.5), een eerste verklaring voor de waargenomen verschillen gegeven. In paragraaf 5.4 wordt getracht een antwoord te geven op de vraag welke arts-en patiëntgebonden factoren van invloed zijn op de aoduur en in welke mate deze factoren het verschil in ao-duur verklaren. Het gaat hier niet meer om het verschil in ao-duur tussen de patiënten van de $\mathrm{vg}$ en ba/vg, maar om de verschillen in ao-duur van de totale, door $\mathrm{vg}$ en ba/vg verzorgde patientenpopulatie. 


\subsection{Analyse-resultaten}

In deze paragraaf wordt onderzocht welke variabelen invloed hebben op de arbeidsongeschiktheidsduur; achtereenwolgens wordt ingegaan op:

- de onafhankelijke variabele wachttijd (par. 5.4.1);

- de overige onafhankelijke wariabelen (par. 5.4.2);

- de correlatie tussen de onafhankelijke variabelen en de arbeidsongeschiktheidsduur (par. 5.4.3), en

- de multiple regressie-analyse: inleiding (par. 5.4.4) en resultaten (par. 5.4.5).

\subsubsection{De onafhankelijke variabele: wachttijd, in relatie tot de ao-duur}

Onder wachttijd wordt verstaan de tijdspanne tussen het moment van ziekmelding en het eerste contact tussen patiënt en vg of ba/vg in het kader van dit onderzoek. Dit betekent, dat het mogelijk is dat vóór de start van de registratie in het kader van dit onderzoek reeds contact tussen patiënt en $\mathrm{vg}$ of $\mathrm{ba} / \mathrm{vg}$ is geweest. Op grond van de regelgeving en werkwijze bij de deelnemende instellingen is het niet te verwachten dat contacten vóór de 4e week veelvuldig voorkomen: zij zijn eerder uitzondering dan regel. Dit betekent, dat de wachttijd overeenkomt met de periode, waarin geen sprake is van enige vorm van verzekeringsgeneeskundige begeleiding (Soeters, 1983). Bovendien is de wachttijd zowel in relatie tot het ziekteverzuim alsook beleidsmatig een uitermate relevant gegeven. Wat het ziekteverzuim betreft: de wachttijd kan een mat zijn voor de emst van de ziekte en kan tegelijkertijd bijdragen tot langdurig ziekteverzuim. Wat het beleidsmatige belang betreft, dient met name gedacht te worden aan het streven van de overheid naar volumebeperking van de sociale verzekeringen en - in dit kader - de discussie rond de herinrichting van de uitvoering van de sociale verzekeringen. Waar het uitblijven van verzekeringsgeneeskundige interventies bij ernstige ziekten terecht en onvermijdelijk kan zijn, bestaat de indruk dat een snelle verzekeringsgeneeskundige interventie vaak de ao-duur kan bekorten door het in stand houden of herstel van de relatie tussen patiënt en bedrijf en het treffen van reintegratiebevorderende maatregelen. De onafhankelijke variabele: wachttijd, is niet in de navolgende multiple regressie-analyse meegenomen. De wachttijd is namelijk ten dele logisch gerelateerd met de verzuimduur. Een zeer lange wachttijd impliceert een lang verzuim. Bovendien kan bij een aantal aandoeningen bewust het beleid gevoerd worden om af te wachten, bijvoorbeeld gezien de ernst van de aandoening. Desalniettemin is het interessant om na te gaan of de wachttijd zelf ook van invloed is op de totale verzuimduur. Daartoe zijn de correlaties berekend tussen wachtijd en verzuimduur op de onderzoekspopulatie. De onderzoekspopulatie omvat de patiëntenpopulatie, waarvan patiëntgegevens beschikbaar zijn (zie paragraaf 5.2.2) en die voldoet aan het leeftijdscriterium (20-40 jaar). Tabel 5.14 bevat een overzicht van de correlatie tussen wachttijd en ao-duur van de onderzoekspopulatie $(\mathrm{N}=315)$. 
Tahel 5.14 Correlate-coufficienten (Pearson) tussen wachthijd en a0-duur wan de ondersoekspopulatie $(N=315)$ nar diagnosegroep

\begin{tabular}{lccc} 
onderzokspopulatie & $r$ & & N \\
\hline alle diagnosen & 0.90 & $* *$ & 214 \\
$Z$. van bet bewegingsitelgat & 0.93 & $* *$ & 86 \\
overige diagnosen & 0.87 & $* *$ & 82 \\
\hline
\end{tabular}

Hin $\mathrm{p} \leq 0.01$

De correlatie tussen wachtijd en ao-duur in de onderzoekspopulatie is significant voor de diagnosegroepen: alle diagnosen, ziekten van het bewegingsstelsel en averige diagnosen. De diagnosegroep: psychische ziekten is te gering van omwang $(\mathrm{N}=46)$ om in deze analyse mee te nemen.

De wachttijd kan op een tweetal manieren aan de verzuimduur gerelateerd zijn. In de eerste plaats kan de wachttijd aanleiding zijn tot een uitstel van hersteldverklaring of wan andere activiteiten, die herstel bevorderen. In dit geval kan beïnvloeding wan de wachttijd leiden tot een verkorting wan de verzuimduur. In de tweede plaats kan de wachtijd cen indicatie zijn voor de ernst van de aandoening, zoals deze bijv. aangegeven kan zijn door de rapporteur/controleur. In dit laatste geval bepaalt de ernst van de ziekte in hoge mate de wachttijd en de uiteindelijke ziekteduur.

Een voor de hand liggende vraag is of en zo ja in welke mate er een relatie is tussen wachitijd en ao-duur in de verschillende ao-dunrklassen. Om dit te onderzoeken in de patiëntenpopulatie verdeeld in ao-duurklassen, en wel: kort ( $\leq 57 \mathrm{~d}$.), middellang $(58 \mathrm{t} / \mathrm{m} 70 \mathrm{~d}$.) en lang ( $>70 \mathrm{~d}$.). Per diagnosegroep is de relatie tussen wachttijd en aoduur onderzocht. Tabel 5.15 bevat een overzicht hiervan.

De relatie tussen wachttijd en aomduurklasse in de onderzoekspopulatie is voor de korte ( $\leq 57 \mathrm{~d}$ ) en lange ( $>70 \mathrm{~d})$ duurklassen significant voor alle diagnosegroepen; hierbiy valt op dat de relaties bij de lange duurklasse sterker zijn dan bij de korte duurklasse. Deels wordt dit veroorzaakt door de wachtijid zelf, die mede de plaats in de duurklassen beinvloedt.

Bij de middellange $(58 \mathrm{l} / \mathrm{m}$ 70d) duurklasse is geen significante correlatie aantoonbaar. Dit laatste kan het gevolg zijn van de geringe orrvang van de duurklasse (12 dagen) en de daardoor geringere variantie. De samenhang tussen wachttijd en verzuimduur van maximaal 57 dagen kan hoogst waarschijnlijk werklaard worden door de regelgeving van de uitvoeringsorganisaties.

Deze regelgeving, die in vele gevallen bepaalt dat een rapporteur/controleur de eerste controles verricht, leidt ertoe, dat de arts relatief laat bij de begeleiding wordt betrokken. Dit geldt vermoedelijk ook voor de emstiger gevallen. Ook de aan de patiënt toegekende eigen verantwoordelijkheid voor hun ziekteverzuim, zeker bij kortdurende ziekten, zal vele artsen weerhouden van een snelle interventie. De verzuimduur in de klasse $\leq 57$ dagen hangt in hoge mate samen met de wachttijd. 
Tabel 5.15 Correlatie-coefficiènten (r) tussen wachttijd en ao-duurklassen naar diagnasegroep van de onderzockspopulatie $(\mathrm{N}=315)$

\begin{tabular}{|c|c|c|c|c|c|c|c|c|}
\hline \multirow[t]{2}{*}{ onderzoekspopulatie } & \multicolumn{3}{|c|}{$\leq 57 \mathrm{~d}$} & \multicolumn{2}{|c|}{$58 \mathrm{u} / \mathrm{m} 70 \mathrm{~d}$} & \multicolumn{3}{|c|}{$>70 \mathrm{~d}$} \\
\hline & $r$ & $\mathbb{N}$ & & $r$ & $\mathbb{N}$ & r & $\mathrm{N}$ & \\
\hline alle diagnosen & 0.60 & 85 & 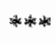 & 0.03 & 38 & 0.91 & 91 & $* * *$ \\
\hline psychische ziekte & 0.58 & 16 & $*$ & 0.32 & 11 & 0.90 & 19 & 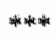 \\
\hline bewegingsstelsel & 0.47 & 32 & $* *+*$ & 0.14 & 12 & 0.95 & 42 & $* * * *$ \\
\hline
\end{tabular}

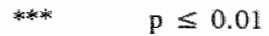

*** $0.01<p \leq 0.05$

Opvallend is de hoge correlatie tussen wachttijd en ao-duur in de onderzoekspopulatie bij de duurklasse > 70d: een lange wachtijj gaat daar gepaard met een relatief lange ziekteduur. Dit kan het gevolg zijn van het late contact tussen $v g$ en patiënt ingeval van ernstige ziekte: de emst bepaalt dan de duur én de wachttijd. Daarnaast is het mogelijk, dat in de duurklasse $>70$ dagen zich vele gevallen bevinden, waarop de arts weinig grip heeft en die niet actief begeleid (kunnen) worden. De vg en ba/vg laten hun beleid wellicht in deze duurklasse veelal afhangen van de interventies van de curatieve sector; interventies van de curatieve sector worden dan als legitimatie gebruikt voor non-interventie van de vg of ba/kg.

De wachttijd wordt beïnvloed door de ernst van de ziekte, de interventies van de curatieve sector en de beleidsruimte van de $\mathrm{vg}$ of $\mathrm{ba} / \mathrm{vg}$. Hoewel de ernst van de ziekte noch de beleidsruimte van de $\mathrm{vg}$ of ba/vg bekend zijn, kan de hoge correlatie tussen wachttijd en ao-duur bij de ziekten van het bewegingsstelsel in de duurklassen $\leq 57 \mathrm{~d}$. en 58-70d. pleiten voor een snelle beoordeling; hiervan gaat mogelijk een verkortend effect uit op de ao-duur. De interventies van de curatieve sector, bijv. het voorschrijven van fysiotherapie, kunnen mede oorzaak zijn van de lange wachttijd. Hierbij dient bedacht te worden, dat fysiotherapie in de regel voor een periode van 6 weken wordt voorgeschreven of gepraktiseerd. De behandelend huisarts zal alvorens te besluiten tot fysiotherapie eerst gedurende enige weken het eigen beleid niet met succes bekroond hebben gezien. Het ontbreken van een significant werband tussen wachttijd en ao-duur bij de duurklasse $>70$ dagen bij de diagnosegroep ziekten van het bewegingsstelsel kan een gevolg zijn van het beëindigen cq. niet verlengen van de fysiotherapie. Ook bij de groep psychische ziekten is geen significante correlatie ussen wachttijd en ao-duur aantoonbaar; blijkbaar heeft hier een relatief snelle vg-beoordeling geen effect op de uiteindelijke ao-duur.

\subsubsection{De onafhankelijke variabelen}

Op de ao-duur is invloed te verwachten van onder andere de volgende arts- en patiëntgebonden factoren: de soort arts en omvang van zijn dienst, de werkwijze en werkervaring van de arts, de taakopvatting van de arts, de gezondheidstoestand van de patiënt en de aard en inhoud wan het werk van de patiënt. Onderstaand wordt een be- 
schrijving gegeven van de onafhankelijke variabelen, welke deze factoren vertegenwoordigen. De variabelen zijn gegroepeerd conform de indeling ten behoeve van de multiple regressie-analyse met groepen variabelen.

soort arts

omvang dienst vg: deze variabele geeft an of de arts $\mathrm{vg}$ of $\mathrm{ba} / \mathrm{vg}$ is.

aantal collega's: Deze variabele geeft inzicht in de omvang wan de dienst, waarbinnen de arts werkzaam is. Een hoge waarde betekent een groot aantal collega $\mathrm{vg}^{3} \mathrm{n}$ of ba/vg'n op de werkplek.

werkwijze/-ervaring datum indienstreding: een mat voor de duur van het dienstverband. Hoe hoger de waarde is, des te korter de duur van het dienstverband.

aamial su-patienten: het aantal spreekuurbeoordelingen per week. Het geaft inzicht in de werkwijze en de werkervaring van de arts. Hoe hoger de waarde is, des te meer patiënten ziet de vg of ba/vg op het spreekuur.

professionaliteit

intercollegiale toetsing: hoe hoger de waarde is, des te meer intercollegiale toetsingsactiwiteiten er worden ontplooid.

scholingsactiviteiten: bij- en nascholingsbijeenkomsten en klinische bijeenkomsten zijn een maat voor de professionalisering van de arts.

Hoe hoger de waarde, des te meer bij- en nascholingsactiviteiten worden er ontplooid.

werkbeleving/ taakopvatting

tevredenheid met werk: hoe hoger de waarde is, des te ontevredener de $\mathrm{vg}$ of ba/vg is met zijn werk. bedriffs-vg: een lage waarde vertegenwoordigt een sterk op de reintegratie gerichte en ten behoeve hiervan een bedrijfsgerichte taakopvatting van $\mathrm{wg}$ of ba/vg.

groeps-vg: een lage waarde vertegenwoordigt een sterk op de groepspreventie gerichte takopvatting van $\mathrm{vg}$ of ba/vg.

indiv.-vg: een lage waarde vertegenwoordigt een sterk op controte en individuele begeleiding gerichte taakopvatting van $\mathrm{vg}$ of $\mathrm{ba} / \mathrm{vg}$.

Bovenstaande variabelen zijn een maat voor de werkbeleving en taakopvattingen van de artsen.

gezondheid patiënt Specialist geraadpleegd: een hoge waarde betekent dat de specialist niet is geraadpleegd. 
geboortejaar patient: hoe hoger de waarde, des te jonger is de patiènt.

Laatstgenoemde variabelen zijn een maat voor de gezondheidstoestand en herstelkansen van de patient.

Tabel 5.16 Correlatie tussen onafhamkelijke variabelen en afhankelijke variahele (avo-duur) en onafhankelijke variabelen onderling van de onderzoekspopulatie, alle diagnosegroepen $(N=206)$

afhankelijke variabele:

onafluankelijke wariabele:

ao-duer

0. verzekeringsgeneeskundige

1. aankal collega-artsen

2. zantal su-patzënten per week

3. daturn indiensttreding

4. bij en nascholing

5. intercollegiale toetsing

6. teverdentheid met werk

7. bedrijfs-vg

8. indiv.-th

9. groeps $\vee \mathrm{gg}$

10. geboortejaar patient

11. specialist geraadpleegd door patient

12. opleidingsniveau patient

13. zwarte werk patiënt

\begin{tabular}{|c|c|c|c|c|c|c|c|c|c|c|c|c|c|c|c|}
\hline & ao-duur & 0 & 1 & 2 & 3 & 4 & 5 & 6 & 7 & 8 & 9 & 10 & 11 & 12 & 13 \\
\hline 0 & .17 & & & & & & & & & & & & & & \\
\hline 1 & -.22 & -.01 & & & & & & & & & & & & & \\
\hline 2 & .23 & .38 & .09 & & & & & & & & & & & & \\
\hline 3 & .07 & -.16 & .08 & -.22 & & & & & & & & & & & \\
\hline 4 & -.24 & -.40 & .07 & -.02 & .34 & & & & & & & & & & \\
\hline 5 & -.07 & -.10 & .14 & .08 & .07 & .22 & & & & & & & & & \\
\hline 6 & -.07 & .17 & .06 & 12 &. .07 & -.17 & -.02 & & & & & & & & \\
\hline 7 & .24 & .63 & .05 & .03 & .02 & -.23 & .09 & .03 & & & & & & & \\
\hline 8 & .04 & .05 & -.26 & .03 & -.47 & .03 & -.17 & .11 & .15 & & & & & & \\
\hline 9 & .09 & -.14 & -.06 & -.19 & -18 & -10 & -.07 & -.11 & -.26 & .06 & & & & & \\
\hline 10 & .02 & .09 & .11 & -.04 & .07 & -.03 & .02 & .04 & .06 & -.09 & .08 & & & & \\
\hline 11 & $\ldots 12$ & .02 & .05 & .08 & .00 & .04 & .02 & .04 &. .03 & .04 & -.06 & -.02 & & & \\
\hline 12 & .10 & -.17 & -.13 & -.38 & -.01 & -10 & .00 & -.15 & -.03 & .13 & .16 & .09 & -.09 & & \\
\hline 13 & -.09 & -.17 & -.03 & -.15 & -.13 & -.04 & -.02 & -.01 & $-\| 1$ & .13 & .10 & -.02 & -.07 & .27 & \\
\hline
\end{tabular}

aard/inhoud werk

zwaarte werk: deze variabele is een maat voor de zwaarte van de arbeid naar de mening van de patiënt. Hoe hoger de waarde, des te lichter is de arbeid.

opleidingsniveau: deze variabelle is een maat voor het opleidingsniveau van de patiënt. Een hoge waarde betekent een hoge opleiding. 
Deze variabelen zing een maat voor de aard en de inhoud van het door de patuent verrichte werk.

In tabel 5.16 is weergegeven of en zo ja, in welke mate de onafhankelijke variabelen onderling samenhangeri. Er bestaat een sterke samenhang wssen de onafhankelijke variabele: $v g$, en de onafhankelike variabele: bedrijs-vg.

Om een tweetal redenen is besloten bij de multiple regressie-analyse uitsluitend gebruik te maken van de onafhankelijke variabele: bedrijfs-vg, en wel

1. ondat de variabele bedrijfs vg geen dichotone variabele is, en

2. omdat de variabele bedrifs-vg sterker samenhangt met de ao-duur dan de variabele vg.

\subsubsection{De correlatie tussen de arbeidsongeschiktheidsduur en de onafhankelijke variabelen: onderzoekspopulatie}

In deze paragraaf wordt het verband aangegeven tussen de arbeidsongeschiktheidsduur en de onafhankelijke variabelen. De correlatiecoëfficiënt (r) geeft aan hoe sterk het lineaire verband is ussen de variabelen; hoe hoger de $r$, hoe sterker het verband. Het teken $(+$ of - geeft de richting van het verband aan. Deze analyse is uitgevoerd op de onderzoekspopulatie $(\mathrm{N}=315$ ). Uiteraard kunnen alleen die patiënten van de onderzoekspopulatie in de analyse betrokken worden, waarvan de ao-duur en de verschillende onafhankelijke variabelen bekend zijn. Deze gegevens zijn miet in alle gevallen beschikbaar. Het aantal aan de analyse deelnemende patienten ligt om deze reden lager dan 315 .

Uit tabel 5.17 blijkt, dat voor de diagnosegroep: alle diagnosen, van de onderzoekspopulatie geldt, dat een lange ao-duur samenhangt met:

1. een relatief klein aantal collega-artsen op de werkplek wan de $\mathrm{vg}$ en ba/vg,

2. een relatief gering aantal spreekuturpatienten,

3. relatief weinig bij- en nascholing,

4. een relatief gering op het bedrijf en de reintegratie van de patient gerichte taakopvalting, en

5. het radplegen van een specialist door de patient.

De cortelaties tussen de onathankelijke variabelen onderling van de verschillende diagnosegroepen zijn opgenomen in bijlage 7. De correlaties tussen de onafhankelijke variabelen en de ao-duur wan de verschillende diagnosegroepen is weergegeven in par. 5.4 .5 
Tabel 5.17 Correlatie-coëficiënten tussen onafhankelijke variabelen en ao-dlutur wan de onderzokspopulatie, diagnosiegroep: alle diagnosen $(\mathrm{N}=200)$

\begin{tabular}{|c|c|c|}
\hline \multirow[t]{2}{*}{ onderzoekspopulatie } & \multicolumn{2}{|c|}{ allo diagnosen } \\
\hline & i & $p$ \\
\hline \multicolumn{3}{|l|}{ organisarie } \\
\hline $\begin{array}{l}\text { 1. aantal arts-collega's } \\
\text { werkowijze }\end{array}$ & -0.22 & and \\
\hline 2. datum indienstreding & 0.07 & \\
\hline 3. amtal su-patienten & -0.23 & 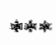 \\
\hline \multicolumn{3}{|l|}{ professionalisering } \\
\hline 4. intercollegiale toetsing & -0.07 & \\
\hline $\begin{array}{l}\text { 5. bij-en nascholing } \\
\text { opwating/werkbelewing }\end{array}$ & -0.24 & wat \\
\hline 6. tevredenheid & -0.07 & \\
\hline 7. taakopvatting bedr, -vg & 0.24 & 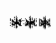 \\
\hline 8. taakopvatting groeps $\vee \mathrm{g}$ & 0.09 & \\
\hline 9. taakopv indiy & 0.04 & \\
\hline \multicolumn{3}{|l|}{ gezondheid patien } \\
\hline 10. spec. geraadpleegd & -0.12 & * \\
\hline 11. geboortejaar & 0.02 & \\
\hline \multicolumn{3}{|l|}{ kenmerken werk pariënt } \\
\hline 12. Zwarte werk & -0.09 & \\
\hline 13. opleidingsniveau & 0.10 & \\
\hline
\end{tabular}

**** $\quad \mathrm{p} \leq 0.01$

$* 0.01<p \leq 0.05$

* $0.05<p \leq 0.10$

\subsubsection{De multiple regressie-analyse: onderzoekspopulatie}

\subsubsection{Inleiding}

De multiple regressie-analyse is een methode om de effecten en de grootte van de effecten op één afhankelijke variabele per onafhankelijke variabele te bepalen. Dit betekent dat de richting en de grootte van de effecten van elk der in paragraaf 5.4.2 beschreven onafhankelijke variabelen op de afhankelijke variabele arbeidsongeschiktheidsduur bekeken is onder constanthouding van alle andere onafhankelijke variabelen. Hierdoor is het mogelijk aan te geven welke onafhankelijke variabelen een eigen invloed hebben op de arbeidsongeschiktheidsduur en hoe groot dit effect is ( $\beta$ eta).

Om inzicht te krijgen of en in welke mate de categorie arts invloed heeft op de aoduur, is de multiple regressie-analyse uitgevoerd op de totale patiëntenpopulatie; daarnaast is de multiple regressie-analyse uitgevoerd op de $\mathrm{vg}$ - en ba/vg-populaties.

In welke mate een variabele de verschillen in arbeidsongeschiktheidsduur verklaart wordt aangegeven door de $\mathrm{R}^{2}$-coëfficiënt. De $\mathrm{R}^{2}$-coëfficiènt is het kwadraat van de waargenomen en voorspelde waarde van de afhankelijke variabele (ao-duur). Indien een variabele of groep variabelen in de analyse wordt ingevoerd, geeft de $R^{2}$ aan of 
deze nieuw toegevoegde variabele of groep variabelen een hogere verklaring geeft. Naarmate de $\mathrm{R}^{2}$ meer de walarde van 1 benadert, draagt de betreffende onafhankelijke variabele meer bij aan de verklaring van de variantie in de afhankelijke variabelen.

De multiple regressie-analyse is toegepast op de onderzoekspopulatie en de verschillende diagnosegroepen van de onderzoekspopulatie.

De multiple regressie-analyse is op een tweetal manieren uitgevoerd:

a. de stapsgewijze analyse ter bepaling van de rangorde van de mate waarin de diverse onafhankelijke variabelen het werschil in ao-duur verklaren $(\mathrm{p} \leq 0.05)$.

b. de analyse met groepen variabelen: de onafhankelijke variabelen zijn geordend naar omschreven kenmerken van de arts en patiënt; vervolgens is per soort kenmerk onderzocht in welke mate deze groepen wariabelen verschillen in ao-duur werklaren. Dit biedt de mogelijkheid aan te tonen of solitaire variabelen, die op zich het verschil in ao-duur niet verklaren, als groep variabelen eventueel wel significant verklarend kunnen zijn.

Achtereenvolgens wordt de multiple regressie-analyse uitgevoerd op de verschillende diagnosegroepen van de onderzoekspopulatie, te weten:

1. de diagnosegroep: alle diagnosegroepen (zie hieronder $2 \mathrm{t} / \mathrm{m} 4$ );

2. de diagnosegroep: zickten van het bewegingsstelsel, en

3. de diagnosegroep: overige diagnosen. Hieronder vallen de ziekten van de ademhalingswegen, ziekten van het hart- en vaatstelsel en ongevallen.

De diagnosegroep: psychische ziekten, is te gering van ormvang om aan de analyses te kunnen deelnemen.

De multiple regressie-analyses zijn uitgevoerd met de in paragraaf 5.4.2 opgenomen onafhankelijke variabelen. Allereerst is wat de onderzoekspopulatie betreft onderzocht welke onafhankelijke variabelen een samenhang hebben met de verschillen in ao-duur. Deze stapsgewijze analyse is beschreven in par. 5.4.4.2). De multiple regressie-analyse met groepen variabelen is voor wat de onderzoekspopulatie betreft beschreven in par. 5.4.4.3. Tot slot is de multiple regressie-analyse, stapsgewijs en met groepen variabelen, uitgevoerd op de verschillende diagnosegroepen van de onderzoekspopulatie, uiteraard voorzover de omvang van deze deelpopulaties analyse toelaten. Deze analyse is beschreven in par. 5.4.5. In deze paragraaf zijn tevens de correlaties tussen onafhankelijke variabelen voor de verschillende diagnosegroepen van de onderzoekspopulatie beschreven.

\subsubsection{Multiple regressie-analyse: stapsgewijs}

De stapsgewijze multiple regressie-analyse van de onderzoekspopulatie (tabel 5.18) toont een samenlang tussen een relatief korte ao-duur en 
a. een taakopvatting, wan waaruit de $\mathrm{vg}$ of ba/vg zich richt op de reintegratie, waarbij sterk geanticipeerd wordt op het werk en de werkomstandigheden van de patient: de taakopvating bedrijfs-vg;

b. het op het dagelijks spreekur zien van een relatief groot aantal patienten;

c. een relatief groot aantal collega-artsen op de werkplek van de $\mathrm{vg}$ of ba/vg, en

d. het relatief veelvuldig volgen van bij- en nascholing door de vg of ba/vg.

Onderzoeken we uitsluitend het door de vg verzorgde deel van de onderzoekspopulatie (tabel 5.19), dan blijkt de taakopvatting bedrijfs-vg geen significante samenhang meer te bezitten met de ao-duur. Dit wordt verklaard door de al eerder waargenomen hoge correlatie tussen de categorie arts: vg, en de taakopvatting: bedrijfs-vg (tabel 5.16).

Tabel 5.18 Multiple regressie-analyse, stapsgewijs: samenhang tussen ao-duur en onafhankelijke variabellen van de onderzoekspopulatie, alle diagnosegroepen $(N=206)$

\begin{tabular}{|c|c|c|c|}
\hline on athankelijke variabelen & $B$ & $\mathrm{R}^{2}$ & \\
\hline \multicolumn{4}{|l|}{ onderzoekspopulatie } \\
\hline bedrijfs-vg & 0.24 & 0.06 & 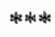 \\
\hline alnntal su-patiënten & -0.24 & 0.11 & 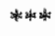 \\
\hline astntal arts-collega"s & -0.22 & 0.16 & 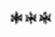 \\
\hline bij. en nascholling & -0.18 & 0.19 & 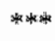 \\
\hline
\end{tabular}

****: $p \leq 0.01$

Tabel 5.19 Multiple regressie-analyse, stapsgewijs: samenthang tussen su-duur en onathankelijke variabelen van het door de vg verzorgde deel van de onderzoekspopulatie, alle diagnosegroepen $(\mathrm{N}=$ 163)

\begin{tabular}{l|ccc}
\hline onafhankelijke wariabelen & B & $\mathbf{R}^{2}$ & \\
\hline vo-onderzoekspopulatie & & & \\
aantal su-patiënten & -0.37 & 0.14 & $* * *$ \\
aantal arts-collega"s & -0.18 & 0.17 & $* * *$ \\
bij-en nascholing & -0.15 & 0.19 & $*$ *w* \\
\hline
\end{tabular}

* $0.01<p \leq 0.05$

\subsubsection{Multiple regressie-analyse met groepen variabelen}

De groepen variabelen, welke gebruikt worden bij dit deel van de multiple regressieanalyse, zijn - zoals in paragraaf 5.4 .2 weergegeven - de arts-variabelen: de omvang van de dienst, de werkwijze, de mate van professionalisering, de werkbeleving en takopwatting, en de patiënten-variabelen: gezondheid en aard/inhoud wan het werk. De variabelen worden in de analyse in een vaste volgorde ingevoerd; allereerst de artsenvariabelen, vervolgens de patiënten-variabelen. Tot deze volgorde is besloten om de volgende reden: dit onderzoek richt zich op het handelen van artsen en het effect daarvan; de artsgebonden variabelen staan centraal. 
De groepsgewijze multiple regressie-analyse toont wat de totale onderzoekspopulatie betreft (tabel 5.20) eenzelfde beeld als de stapsgewijze multiple regressie-analyse. Evenals bij de stapsgewijze multiple regressie-analyse (tabellen 5.18 en 5.19) is ook hier sprake van een samenhang tussen een relatief korte ao-duur en een groot aantal collega-artsen op de werkplek van de arts, een groot aantal spreekuurpatiënten, het veelvuldig volgen van bij-en nascholing en de taakopvatting bedrijfs-vg.

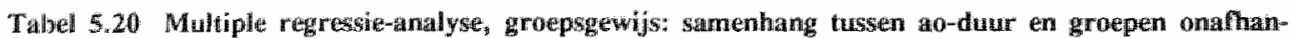
Wellike variabulen: van de onderoukspopulatie $(N=206)$

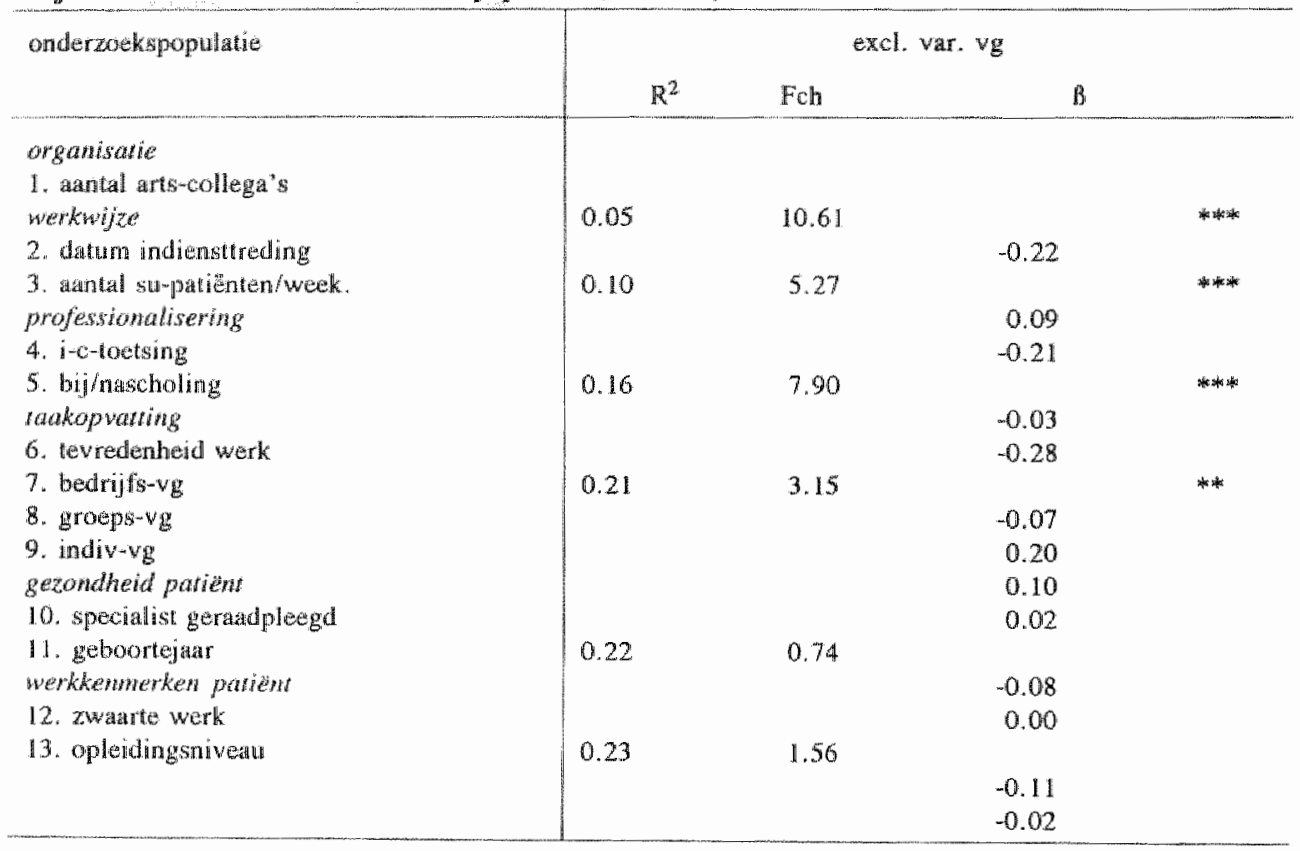

$\begin{aligned} 0.01<0 & \leq 0.01 \\ 0 & \leq 0.05\end{aligned}$

Als de analyse wordt uitgevoerd op het door de vg verzorgde deel van de onderzoekspopulatie (tabel 5.21), verdwijnt de samenhang tussen de ao-duur en de taakopvatting: bedrijfs-vg. Dit is een gevolg van de hoge correllatie tussen onafhankelijke variabelen: categorie arts: vg, en de takopvalting: bedrijfs-vg (tabel 5.16). 
Tabel 5.21. Multiple regressie-analyse, groepsgewijs: samenhang tussen av-duur en grocpen onafhankelijke variabelen op het door de vg verzorgde deel wan de onderzockspopulatie $(\mathrm{N}=163$ )

\begin{tabular}{|c|c|c|c|c|}
\hline onderzoekspopulatie & $\mathbb{R}^{2}$ & Foh & 䟥 & \\
\hline organisatie & 0.05 & 8.74 & & * \\
\hline 1. aantal arts-collega's & & & -0.23 & \\
\hline werkwiple & 0.18 & 11.92 & & $*$ \\
\hline 2. dstum indiensttreding & & & 0.13 & \\
\hline 3. aantal su-patiênten/week. & & & -0.34 & \\
\hline $\begin{array}{l}\text { professionalisering } \\
\text { 4. intercollegiale toetsing }\end{array}$ & 0.21 & 3,46 & -0.07 & *** \\
\hline 5. bij-en/mascholing. & & & -0.21 & \\
\hline opwating/werkbelewing & 0.24 & 1.32 & & \\
\hline 6. verredenheid met werk & & & -0.11 & \\
\hline 7. taakopvatting bedr. -vg & & & 0.10 & \\
\hline 8. thakopvatting groeps-ug & & & 0.07 & \\
\hline 9. thatkopvatting indiv-vg & & & 0.08 & \\
\hline gezondheid parient & 0.24 & 0.68 & & \\
\hline 10. patiënt: specialist geraadpleegd & & & -0.08 & \\
\hline 11. patient: geboortejaar & & & 0.00 & \\
\hline kemmerken werk patiëm & 0.26 & 1.36 & & \\
\hline 12. patient: zwalrte werk & & & -0.12 & \\
\hline 13. patiënt: opleidingsnivent & & & 0.00 & \\
\hline
\end{tabular}

$* * * * 0.01<0$
$* 0.01$

\subsubsection{De diagnosegroepen}

\subsubsection{De correlatie tussen ao-duur en de onafhankelijke variabelen in de ver- schillende diagnosegroepen}

De correlatie tussen de diagnosegroepen: ziekten van het bewegingsapparaat en overige diagnosen, van de onderzoekspopulatie is weer gegeven in tabel 5.22.

Bij de diagnosegroep ziekten wan het bewegingsstelsel bestaat er een correlatie tussen een relatief korte ao-duur en een groot aantal collega-artsen op de werkplek van de vg of ba/vg en een bedrijfsgerichte taakopvatting. Bij de diagnosegroep: overige diagno sen, vinden we een zeer sterke samenhang tussen een relatief lange duur van het dienstverband van de $\mathrm{vg}$ of ba/vg en een korte ao-duur. Vermoedelijk speelt ervaring hier een belangrijke rol. Daarnaast bestaat er in de diagnosegroep: overige diagnosen een samenhang tussen een korte ao-duur en een relatief hoge mate van bij- en nascholing en een bedrijfsgerichte taakopvatting van de arts. Er bestaat een samenhang tussen een lange ao-duur en het raadplegen van een specialist door de patiënt en een relatief hoge opleiding van de patiènt. 
Tabel 5.22 Correlatie-coafficinten tussen onathanketijhe wariabelen en ao-duw wan de onderwoekspopulatie, diagnosegroepen: ziekten wan het bewegingsstelsel $(\mathrm{N}=83)$ en overige diagnosen $(\mathbb{N}=78)$

\begin{tabular}{|c|c|c|c|c|}
\hline \multirow[t]{2}{*}{ Onderzoekspopulate } & \multicolumn{2}{|c|}{ Ziekten v. bewegingsatelsel } & \multicolumn{2}{|c|}{ owenge diagnosen } \\
\hline & $\mathbb{1}^{\mathbf{t}}$ & $p$ & I & $\mathrm{p}$ \\
\hline \multicolumn{5}{|l|}{ argansarie } \\
\hline $\begin{array}{l}\text { 1. aratal arts-collegats } \\
\text { werkwijge }\end{array}$ & -0.28 & *** & .0 .10 & \\
\hline 2. datum indienstreding & -0.08 & & .0 .50 & $* *$ \\
\hline 3. aanulal su-paljerten & 0.13 & & 0.01 & \\
\hline \multicolumn{5}{|l|}{ profestionalisering. } \\
\hline 4. intercollegiale toetsing & -0.08 & & -0.09 & \\
\hline 5. bijm en nascholing & -0.07 & & -0.39 & wa* \\
\hline \multicolumn{5}{|l|}{ opwationg werkbeleving } \\
\hline 6. tevredenheid & 0.06 & & -0.08 & \\
\hline 7. takopwatting bedr.wg. & 0.19 & * & 0.33 & $* * m$ \\
\hline 8. taakopvatting groeps-vg & -0.07 & & 0.30 & \\
\hline 9. taakopw indiv. vg & 0.14 & & -0.15 & \\
\hline \multicolumn{5}{|l|}{ gezondheid pariena } \\
\hline 10. sperial ist geraadplezgd & -0.10 & & -0.23 & *w* \\
\hline 11. geboortejant & 0.15 & & -0.01 & \\
\hline \multicolumn{5}{|l|}{ kemmerk werk partent } \\
\hline 12. zwantte werk & 0.15 & & 0.08 & \\
\hline 13. opleidimgsniveau & -0.08 & & 0.25 & $* *$ \\
\hline
\end{tabular}

$$
\begin{aligned}
& * \quad p \leq 0.01 \\
& * 0.01<\mathrm{p} \leq 0.05 \\
& * 0.05<\mathrm{p} \leq 0.10
\end{aligned}
$$

\subsubsection{Multiple regressie-analyse: diagnosegroepen}

De multiple regressie-analyse is niet alleen uitgevoerd op de totale onderzoekspopulatie, maar ook op de 2 belangrijkste diagnosegroepen van deze onderzoekspopulatie, te weten:

a. de diangnosegroep: ziekten van het bewegingsstelsel, en

b. de diagnosegroep: overige diagnosen, bevattende de ziekten van de ademhalingswegen, het hart- en vaatstelsel en ongevallen. De onvang van de diagnosegroep: psychische ziektien was te beperkt $(\mathrm{N}=44)$ om aan de analyses te kunnen deelnemen.

De stapsgewijze multiple regressie-analyse toont (tabel 5.23) voor wat de diagnosegroep: ziekten van het bewegingsapparaat, betreft een samenhang tussen een relatief korte aomduur en

1. een groot aantal collega-artsen op de werkplek van de $v g$ of $b a / v g$, en

2. de taakopvatting: bedrijfs-vg. 
Tabel 5.23 Multiple regressic-analyse, stapsgewijs: samenhang tussen ao-duur wn orathankelijke pariahelen van de onderzoekspopulatie, diagnasegroepen: ziekten van het bewegingsstellsel $(\mathrm{N}=83)$ en overige diagnosen $(\mathbb{N}=78)$

\begin{tabular}{|c|c|c|c|}
\hline Onafhankeligke wariabelen & $B$ & $\mathrm{R}^{2}$ & \\
\hline \multicolumn{4}{|c|}{$\begin{array}{l}\text { diagnosegroep: ziekten van het bewegings- } \\
\text { stelisel }\end{array}$} \\
\hline antal arts-collega's & -0.27 & 0.08 & $*$ \\
\hline bedrijts-vg & 0.21 & 0.12 & $* *$ \\
\hline \multicolumn{4}{|l|}{ diagnosegroep: overige diagnosen } \\
\hline aantal su-patiënten & -0.50 & 0.25 & * * \\
\hline bij-en nascholing & -0.34 & 0.36 & * \\
\hline bedrijfs-vg & 0.24 & 0.42 & 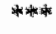 \\
\hline patiënt: specialist geraadpleegd & -0.19 & 0.46 & ** \\
\hline
\end{tabular}

$$
\begin{aligned}
& * * 0.01 \\
& * * 01<\mathrm{p} \leq 0.05
\end{aligned}
$$

Tabel 5.24 Multiple regressie-analyse, groepsgewijs: samenhang tussen awo-dur en onafhankelijke

\begin{tabular}{|c|c|c|c|c|}
\hline \multirow[t]{2}{*}{ Onderzoekspopulatie } & \multicolumn{4}{|c|}{ ziekten $v$. bewegingsstelsel } \\
\hline & $\mathrm{R}^{2}$ & Fch & $B$ & \\
\hline organisatie & 0.08 & 6.62 & & * \\
\hline 1. aantal arts-collega's & & & -0.27 & \\
\hline werklajize & 0.10 & 2.17 & & \\
\hline 2. diatum indiensttreding & & & -0.10 & \\
\hline 3. aantal su-patiênten/week & & & 0.13 & \\
\hline professionalisering & 0.13 & $\mathbb{1 . 1 9}$ & & \\
\hline 4. intercollegiale toetsing & & & -0.05 & \\
\hline 5. bij-en nascholing & & & -0.18 & \\
\hline taakopwating & 0.19 & $\mathbb{1 1 . 3 5}$ & & \\
\hline 6. tevredenheid werk & & & -0.07 & \\
\hline 7. bedrijfs-ug & & & 0.22 & \\
\hline 8. groeps-vg & & & -0.01 & \\
\hline 9. indiv-wg & & & 0.115 & \\
\hline gezondheld patient & 0.21 & 1.03 & & \\
\hline 10. specialist geraadpleegd & & & 0.15 & \\
\hline 11. geboortejaar & & & -0.03 & \\
\hline werkkevimerken patiem & 0.22 & 0.54 & & \\
\hline 12. Zwarte werk & & & 0.12 & \\
\hline 13. opleidingsniveau & & & -0.01 & \\
\hline
\end{tabular}
variabelen van de onderzoekspopulatie, diagnosegroep: ziekten wan het bewegingsstelsel $(\mathrm{N}=83)$ 
De samenhang tussen een korte ao-duur en de onafhankelijke variabelen: bij- en nascholing en het aantal spreekuurpatienten is in tegenstelling tot de waarneming bij de totale onderzoekspopulatie niet meer significant.

Wat de diagnosegroep: overige diagnosen, betreft bestaat er een samenhang tussen een korte ao-duur en een groot aantal spreekuurpatiënten, een hoge mate van bij- en nascholing van de $\mathrm{vg}$ en ba/vg en en bedrijfsgerichte taakopvatting. Het raadplegen van een specialist door de patiënt heeft een samenhang met een relatief lange ao-duur.

Bij de groepsgewijze multiple regressie-analyse (tabel 5.24) wan de diagnosegroep: ziekten van het bewegingsstelsel, bestaat er uitsluitend een samenhang tussen een korte ao-duur en een groot aantal collega-artsen op de werkplek van de $\mathrm{vg}$ of $\mathrm{ba} / \mathrm{vg}$.

Bij de groepsgewijze multiple regressie-anallyse van de diagnosegroep: overige diagnosen, bestaat er een samenhang tussen een korte ao-duur en een groot aantal collegaartsen op de werkplek van de vg of ba/vg, een langdurig dienstverband van de $\mathrm{vg}$ of $\mathrm{ba} / \mathrm{vg}$ en het veelvuldig volgen van bij- en nascholing (tabel 5.25 ).

Uit de analyses ontstaat het volgende beeld:

a. Er is een samenhang tussen een relatief korte ao-duur en een hoge mate van professionaliteit van de $\mathrm{vg}$ en ba/vg. Hierbij wordt het veelvuldig volgen van bij- en nascholing beschouwd als een hoge mate voor de professionaliteit. Deze samenhang vinden we bij zowel de totale onderzoekspopulatie alsook bij de diagnosegroep: overige diagnosen. $\mathrm{Bij}$ de diagnosegroep: ziekten van het bewegingsstelsel, wordt deze samenhang met bij- en nascholingsactiviteiten niet gevonden. Bij deze diagnosegroep is er wel een samenhang tussen een relatief korte ao-duur en een groot aantal collega-artsen op de werkplek. De verklaring van deze samenhang kan gelegen zijn in de nuimere mogelijkheden tot overleg met collega's en tot toetsing van het eigen beleid aan dat van collega's.

b. Er bestaat een samenhang tussen een korte ao-duur en een relatief groot aantal patiënten op het spreekuur. Deze samenhang wordt gevonden bij de diagnosegroep: alle diagnosen, van de totale onderzoekspopulatie en het door de vg verzorgde deel van de onderzoekspopulatie, en bij de diagnosegroep: overige diagnosen. De verklaring kan gelegen zijn in de een grote mate van routine van de $\mathrm{vg}$ of $\mathrm{ba} / \mathrm{vg}$, waarvan een groot aantal spreekuurpatiènten een uiting kan zijn.

c. Er bestaat zowel bij de totale onderzoekspopulatie als de verschillende diagnosegroepen een samenlang tussen een relatief korte ao-duur en de taakopvatting: bedrijfs-vg. Naarmate de $\mathrm{vg}$ of ba/vg zich meer richt op de reintegratie en het bedrijf hierbij betrekt, zal de ao-duur relatief korter zijn.

d. Het raadplegen van een specialist heeft uitsluitend bij de diagnosegroep: overige diagnosen, een samenhang met een relatief lange ao-duur. Ongetwijfeld kan het raadplegen van een specialist beschouwd worden alls een maat voor de ernst van de ziekte, hetgeen de samenhang met een langere ao-duur kan verklaren. Bovendien 
spelen wachtijden in het curatieve circuit alsmede de tijd, die een specialist nodig heeft woor onderzoek en therapie hierbij een niet te onderschatten rol.

Tabel 5.25 Multiple regressie-analyse, groepsgewijs: samenhang tussen an-duur en onathankelijke variabelen van de onderzoekspopulatie, diagnosegroep: overige diagnosen $(\mathrm{N}=78$ )

\begin{tabular}{|c|c|c|c|c|}
\hline Overige dimgnosen & $\mathbb{R}^{2}$ & $\mathbb{F O H}$ & $\mathbb{M}$ & \\
\hline organisatie & 0.01 & 0.79 & & \\
\hline 1. antal arts-collega's & & & -0.10 & \\
\hline Wathowze & 0.27 & 13.00 & & $* *$ \\
\hline 2. datum indiensttreding & & & -0.10 & \\
\hline 3. zantal su patientuen/week & & & -0.50 & \\
\hline professionalisering & 0.37 & 5.72 & & $* * * * *$ \\
\hline 4. intercollegiale toetsing & & & -0.04 & \\
\hline 5. bij-en nascholing & & & -0.35 & \\
\hline opvaring/werkbeleving & 0.49 & 3.91 & & *wow \\
\hline 6. tevredenheid met werk. & & & -0.08 & \\
\hline 7. thakopvalting bedr.-vg & & & 0.26 & \\
\hline 8. thakopvatting groeps-vg & & & 0.20 & \\
\hline 9. taakopvatting undiv, - $\mathrm{vg}$ & & & -0.20 & \\
\hline gezondhetd patient & 0.50 & 1.98 & & \\
\hline 10. specialist geraadpleegd & & & .0 .17 & \\
\hline 11. geboortejar & & & -0.05 & \\
\hline kentmerken werk partent & 0.52 & 0.20 & & \\
\hline 13. zwalrte werk & & & -0.03 & \\
\hline 14. opleidingsniveau & & & 0.06 & \\
\hline
\end{tabular}

* $\quad 0.01$

\subsection{Bespreking van de analyse-resultaten}

In dit hoofdstuk worden de resultaten van de analyses, zoals beschreven in de paragrafen 5.3 en 5.4 op een rij gezet. In paragraaf 5.5.1 worden de verschillen in begeleiding tussen $\mathrm{vg}$ en ba/vg besproken; paragraaf 5.5 .2 bevat een bespreking van de relatie tussen ao-duur en wachttijd. In paragraaf 5.5.3 wordt ingegaan op de variabelen, welke samenhangen met een korte of lange ao-duur.

\subsubsection{Verschillen in begeleiding tussen verzekeringsgeneeskundige en bedriffs- arts/verzekeringsgeneeskundige}

De verschillen in begeleiding kunnen beschreven worden aan de hand van de waargenomen spreekuuractiviteiten van $\mathrm{vg}$ en ba/vg, de oordeelsvorming naar aanleiding van de su-beoordelingen, de begeleidingsplannen en het uiteindelijke effect op de arbeidsongeschiktheidsduur van de door $\mathrm{vg}$ en ba/vg verzorgde populaties. 


\section{De spreekuuractiviteiten}

De spreekuuractiviteiten zijn in kaart gebracht aan de hand van de registratie van het tijdstip van de eerste spreekuurbeoordeling, het aantal herbeoordelingen en de relatie tussen ao-duur en le su-beoordelingen.

De eerste spreekuurbeoordeling. Wat de le su-beoordeling betreft wordt geconstateerd dat de ba/vg eerder een le su-beoordeling verricht dan de vg. Bepalen we het moment van le su-beoordeling als de tijdspanne tussen de le ao-dag en de datum van 1e subeoordleling, dan blijkt de ba/vg de meeste patiënten voor de $50 \mathrm{e}$ ao-dag voor de eerste maal beoordeeld te hebben; het verschil met de vg ( $81 \%$ versus $60 \%)$ is groot. Dit betekent niet, dat de vg pas op dat moment betrokken is bij de arbeidsongeschiktheid; de $\mathrm{vg}$ beschikt immers vaak over lekenrapporteurs. De GAK-vg, $\pm 75 \%$ van de vgonderzoekspopulatie, beschikt altijd over lekenrapporteurs, die - althans ten tijde van dit onderzoek - iedere arbeidsongeschikte op de eerste of tweede dag na de ziekmelding bezochten. De overige Vg'n van het SFB en BVG beschikken in mindere mate over lekenrapporteurs; deze lekenrapporteurs worden echter slechts in bepaalde gevallen, bijv. bij twijfel aan de betrouwbaarheid - ingezet. Op grond van de rapportage van deze lekenrapporteurs kan de vg besluiten dat een le beoordeling op een eerder moment niet zinvol is. Het verschil in moment van le su-beoordeling kan niet verklaard worden uit verschil in ziekten. Op grond van de bij le su-beoordeling gestelde diagnosen is er geen significant verschil tussen de door de $\mathrm{vg}$ en ba/vg begeleide populaties. De grotere afstand van de $\mathrm{vg}$ tot bedrijven en het dientengevolge ontbreken van kennis over specifieke reüntegratiemogelijkheden en contacten met de bedrijfsleiding leidt tot een a-specifieke, niet op de bedrijfsnoden en -mogelijkheden gerichte, begeleiding van de patiënt door de $v g$. Het late tijdstip van le su-beoordeling kan hier een uiting van zijn.

De spreekuurfrequentie. Hoe vaak wordt een patiënt op het spreekuur gezien? Wat betreft de frequentie van su-beoordelingen bestaan significante verschillen tussen de vg en ba/vg (zie tabel 5.8). Zowel het aantal eerste spreekuurbeoordelingen alsook het aantal herhalingsbeoordelingen door de ba/vg ligt significant hoger dan het aantal door de vg verrichte beoordelingen.

Dit lijkt in tegenspraak met het aantal door de vg op het spreekuur beoordeelde patiënten, dat significant hoger ligt dan bij de ba/vg. Ongetwijfeld speelt hier het verschil in omvang van de verzorgde populatie een rol. De vg verzorgt in de regel een werknemerspopulatie van rond de 7.000 werknemers, die per jaar \pm 10.000 à 11.000 ziekmeldingen opleveren; de ba/vg zal in het algemeen ongeveer 2.000 werknemers tot zijn zorg rekenen. Bovendien heeft de ba/vg naast vg ook bedrijfsgeneeskundige taken als onder andere het verrichten van aanstellingskeuringen en periodiek geneeskundig onderzoek en advisering in het kader van de ARBO-wet. Dit betekent dat, hoewel het totaal aantal door de vg begeleide werknemers en het aantal verrichte beoordelingen groter is, het aantal beoordelingen per patiënt lager is. 
Relatie spreekuurbeoordelingen en ao-duur. Het significant hogere percentage door de vg in vergelijking met de ba/vg verrichte énmalige beoordelingen kan niet liggen aan een vroegtijdige melding aan de GMD ter reïntegratie in aangepast of ander werk. Het grote aantal énmalige beoordelingen, dat vooral opvalt bij de langere ao-duurklassen, kan een gevolg zijn van de regelgeving van de uitvoeringsorganisatie, op grond waarvan de vg - en dit geldt met name voor de GAK-wg - relatief laat met de begeleiding start. Dit betekent niet, dat er de eerste maanden niets gebeurt: in veel gewallen is er sprake van inschakeling van huisartsen of niet-medici zoals controleurs en rapporteurs.

De oordeelsvorming en het begeleidingsplan. De oordeelsvorming is in kaart gebracht aan de hand van de le (na ziekmelding) en laatste (voor werkhervatting) su-beoordeling. Wat betreft de oordeelsvorming bestaan er geen significante verschillen tussen vg en ba/vg ten aanzien van de gestelde diagnosen en de verzekeringsgeneeskundige con clusie (arbeidsongeschikt, blijvend of tijdelijk, of niet arbeidsongeschikt) noch ten aanzien van de mate waarin de huisarts en een specialist door de patiënt zijn ingeschakeld.

Wel bestaan er significante verschillen met betrekking tot de geplande begeleidingsactiviteiten en de prognose: de door $\mathrm{vg}$ of $\mathrm{ba} / \mathrm{vg}$ aangegeven verwachting ten aanzien van well of geen hervatting van de patiënt in eigen of ander, al dan niet aangepast, werk.

Het meest opmerkelijke zijn de verschillen in de door de $\mathrm{vg}$ en ba/vg aangegeven begeleidingsplannen: de in het specifieke geval te ondernemen activiteiten, welke gericht zijn op een zo snel en adequaat mogelijke reïntegratie van de patiënt. Ten aanzien van het begeleidingsplan bestaan er significante verschillen tussen $\mathrm{vg}$ en ba/vg, zowel bij le als laatste su-beoordeling. Deze verschillen betreffen met name de gepercipiëerde beïnvloeding van de curatieve sector en de contacten met de werkgever over de te nemen tijdelijke of blijvende reïntegratiemaatregelen.

Wat betreft het overleg met de werkgever over het treffen van tijdelijke maatregelen ter reïntegratie van de patiënt blijkt de $b a / v g$ aanzienlijk actiever dan de vg. Hier speelt ongetwijfeld opnieuw het grote aantal door de $\mathrm{vg}$ verzorgde bedrijven en de grotere afstand tussen $\mathrm{vg}$ en deze bedrijven een belemmerende rol; daarnaast zijn deze bedrijven in de regel kleiner van omvang (minder werknemers) en bieden zij daardoor vaak minder mogelijkheden tot werkaanpassingen. Ook is het mogelijk dat het relatief zware werk in de bouw en de gezondheidszorg, waarmee vg'n van resp. het SFB en de BVG te maken hebben, minder aanpassingsmogelijkheden bieden.

Tevens is de hoge mate, waarin de $\mathrm{vg}$ besluit de curatieve sector, met name de medisch specialist te raadplegen, opvallend. Is de vg zo onzeker, ontbreekt het de vg aan diagnostische mogelijkheden of "vertaalt" de grote afstand tussen vg en bedrijf en het ontbreken van kennis over reïntegratiemogelijkheden zich in een grote behoefte aan medische onderbouwing van de uiteindelijke beslissing: arbeidsgeschikt of arbeidsongeschikt? Of bepaalt de juridische vraag naar het voldoen aan de ziektewetcriteria - arbeidsongeschikt door ziekte of gebrek voor zijn of haar laatstelijk verrichte arbeid - de werkwijze van de $v g$ ? Ook is het mogelijk, dat het grote aantal patiënten, dat de vg per week op het spreekuur ziet (het verschill met de ba/vg is groot) door tijdgebrek leidt tot 
een globalere diagnostick en een groter beroep op de curatieve sector. Dit grote bercep op de curatieve sector maakt de vg in zekere mate afhankelijk van het oordeel van de curatieve arts. Dit curatieve oordeel zal veelal betrekking hebben op de aan- of afwezigheid van ziekte. De vg daarentegen moet oordelen over arbeidsongeschiktheid ten gevolge van ziekte (of gebrek). Dat wil zeggen niet het bestaan van ziekte, maar het bestaan van door ziekte veroorzaakte arbeidsongeschiktheid bepaalt of iemand arbeidsgeschikt of arbeidsongeschikt is. Door zich afhankelijk op te stellen van de curatieve sector en hun oordeel over te nemen, kan de ao-duur onnodig verlengd worden door het gebruik van het onjuist criterium "ziekte" in plaats van "arbeidsongeschiktheid". Opvallend is dat de bovengenoemde verschillen in begeleidingsplan tussen vg en ba/vg niet alleen bij de le, maar ook bij de laatste su-beoordeling waarneembaar zijn.

Het tweede significant werschil in oordeelsvorming betreft de prognose ten aanzien van werkhervatting bij de le su-beoordeling. Het vg-oordeel in deze kenmerkt zich door uitersten: de vg verwacht of een volledige werkhervatting of hij verwacht geen werkhervatting zelf te kunnen realiseren en besluit tot inschakeling van de GMD. Gedeeltelijke werkhervattingen worden door de $\mathrm{vg}$ in tegenstelling tot de ba zelden als een serieuze mogelijkheid gezien. Ziet de vg in vergelijking met de ba/vg bij de le spreekuurbeoordeling relatief weinig mogelijkheden tot werkaanpassing, bij de laatste spreekuurbeoordeling bestaat er geen significant verschil meer tussen de $\mathrm{vg}$ en ba/vg.

\section{De arbeidsongeschilktheidsduur}

Het meest opvallende is het significante verschil in ao-duur tussen de door de $\mathrm{vg}$ en $\mathrm{ba} / \mathrm{vg}$ begeleide arbeidsongeschikte werknemers. Ruim $75 \%$ van de door de ba/vg begeleide patiënten blijkt het werk vóór de $71 \mathrm{e}$ ao-dag te hebben hervat; ongeweer eenderde van deze populatie valt in de ao-duurklasse 57-70 dagen. Van de door de vg begeleide patiëntenpopulatie blijkt slechts $45 \%$ vóór de $71 \mathrm{e}$ ao-dag het werk te hervatten. De grootste groep "hervatters", ruim $20 \%$, bevindt zich in de ao-duurklasse 95 170 dagen.

\section{Resumerend}

De verschillen in begeleiding door $\mathrm{vg}$ en ba/vg betreffen de begeleidingsactiviteiten en oordeelsvorming van de $\mathrm{vg}$ en ba/vg en de gerealiseerde ao-duur.

Wat de begeleidingsactiviteiten betreft kenmerkt de vg zich door een late le su-beoordeling en een relatief gering totaal aantal su-beoordelingen per patiënt. De vg is in vergelijking met de ba/vg passief en afwachtend. Het aantal contacten met de bedrijf is laag. De vg doet darentegen relatief vaak een beroep op de curatieve sector en maakt zich daardoor in grote mate afhankelijk van de curatieve sector. Dit lijkt in contrast te staan met het significant groter aantal su-beoordelingen dat de vg in vergelijking met de $\mathrm{ba} / \mathrm{vg}$ verricht. De verklaring voor een en ander is te vinden in het grote aantal door de vg verzorgde werknemers: de vg-werknemerspopulatie is aanzienlijk groter dan de door de ba/vg verzorgde werknemerspopulatie. 
Wat de oordeelsworming betreft is de ba/vg genuanceerder dan de vg en ziet de ba/vg in tegenstelling tot de $\mathrm{vg}$ relatief meer reintegratiemogelijkheden binnen het bedrijf. Bij de laatste su-beoordeling is er echter geen significant verschil tussen vg en ba/vg met betrekking tot de verwachte reintegratiemogelijkheden. Wat betreft de ao-duur bestat er een significant verschil tussen $\mathrm{vg}$ en ba/vg: de door de $\mathrm{vg}$ begeleide populatie verzuimt langer dan de door de ba/vg begeleide populatie. Bij dit verschil speelt waarschijnlijk een verschil in kennisniveau (mede) een rol, gezien het feit dat de ba/vg aanzienlijk meer bij- en nascholing volgt dan de $\mathrm{vg}$. De ba/vg is wat dat betreft professioneler dan de vg.

\subsubsection{De relatie tussen wachttijd en arbeidsongeschiktheidsduur}

Onder wachttijd wordt verstaan de periode tussen de eerste ao-dag en het eerste verzekeringsgeneeskundig spreekuurbezoek. De wachttijd wordt mede bepaald door het selectiecriterium ao-duur: om aan het onderzoek te kunnen deelnemen diende een patiënt minimaal 4 weken, maximaal 8 weken arbeidsongeschikt te zijn. In de verzekeringsgeneeskundige praktijk zijn spreekuurbeoordelingen vóór de $4 \mathrm{e}$ ao-week eerder vitzondering dan regel. De wachttijd, zoals deze gedefinieerd is binnen het kader van dit onderzoek, komt in hoge mate overeen met de door Soeters (1983) gedefinieerde wachttijd: de periode, waarin geen sprake is van verzekeringsgeneeskundige begeleiding.

De wachttijd en de ao-duur hebben een zeer hoge correlatie. Om deze reden is de wachttijd niet als onafhankelijke variabele meegenomen in de multiple regressie-analyse. De correlatie (Pearson) tussen wachttijd en ao-duur is onderzocht voor de onderzoekspopulatie (selectiecriterium leeftijd). De correlatie tussen wachttijd en ao-duur is significant voor alle diagnosegroepen van de onderzoekspopulatie.

Wordt de onderzoekspopulatie verdeeld in ao-duurklassen, dan blijkt in de duurklassen $\leq 57$ dagen en $>70$ dagen een significante correlatie tussen ao-dur en wachtrijd te bestaan. Er mag worden verondersteld, dat deze correlatie bij de duurklasse $\leq 57$ dagen in hoge mate bepaald wordt door het selectiecriterium: ao-duur bij start van het onderzoek. Bij de duurklasse $>70$ dagen is het aannemelijk dat de ernst van de ziekte van de patiënt de samenhang met een lange ao-duur verklaart. Een relatief ernstige ziekte immers zal vrijwel altijd leiden tot een interventie door curatieve artsen, waardoor het verzuim gelegitimeerd is. De noodzaak of wenselijkheid van een vroegtijdige interventie door de $\mathrm{vg}$ of ba/vg ontbreekt. Dit resulteert veelal in een relatief late eerste interventie door de $\mathrm{vg}$ of $\mathrm{ba} / \mathrm{vg}$. De afwezigheid van een significante correlatie tussen wachttijd en ao-duur bij de duur-klasse $58 \mathrm{t} / \mathrm{m} 70$ dagen kan mede veroorzaakt worden door de geringe omvang van deze duurklasse.

\subsubsection{De relatie tussen variabelen en de arbeidsongeschiktheids-duur}

\subsubsection{De correllatie tussen variabelen en arbeidsongeschiktheids-duur}

De correlatie tussen de onafhankelijke variabelen en de ao-duur is onderzocht. De richting van deze correlaties in de onderzoekspopulatie zijn in tabel 5.26 weergegeven. 
Tabel 5.26 Positieve en neyatieve richting van de correlaties tussen mafhankelijke variabelen ent aoduur, onderanekspopulatie

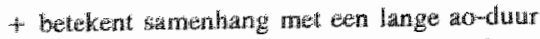

- betelkent samenharig net een korte an-duur

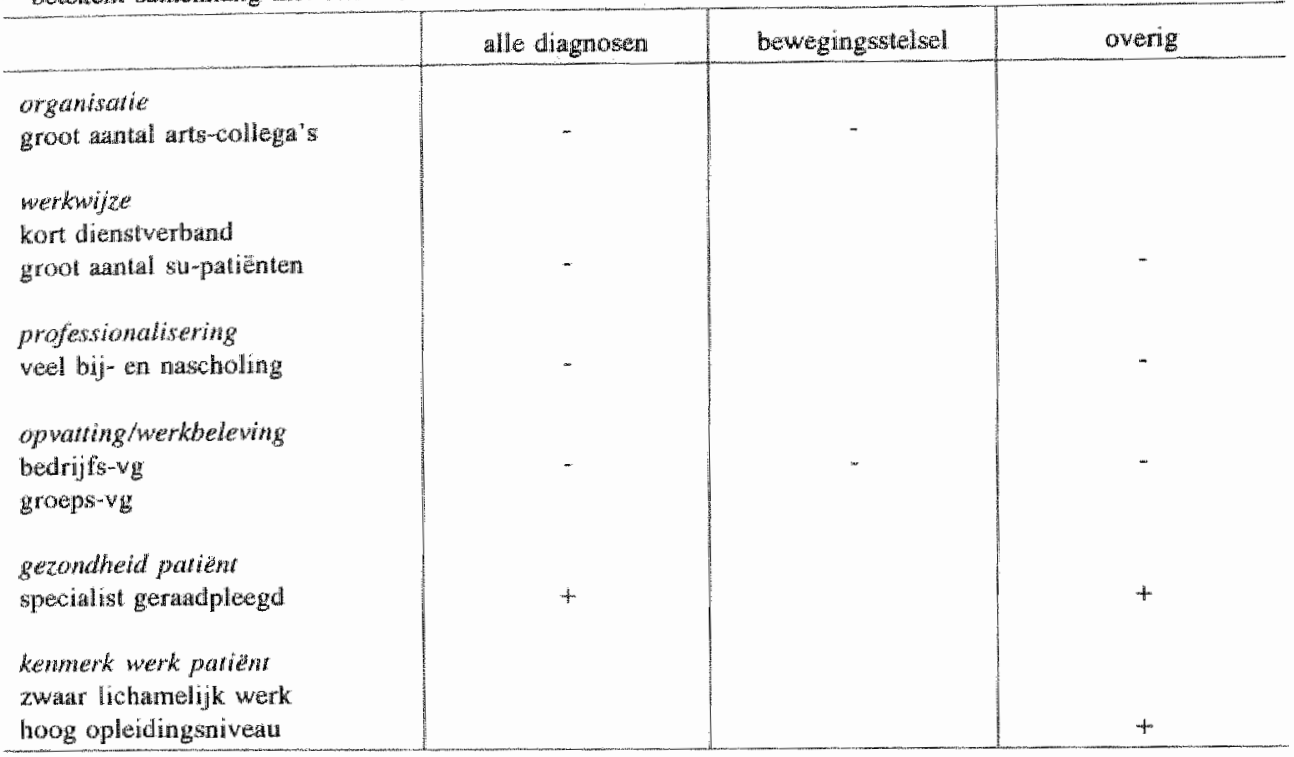

Er bestaat een samenhang tussen de ao-duur en

* het opleidingsniveau van de patiënt. Zowel bij de diagnosegroepen: psychische ziekten en overige diagnosen, bestaat er een significante correlatie tussen een hoog opleidingsniveau van de patiënt en een lange ao-duur. Tot de diagnosegroep: overige diagnosen, behoren de ziekten van het hart- en vaatstelsel, de ademhalingswegen alsook ongevallen. Hoewel de aard van de ziekte (psychische ziekten, harten vaatziekten, bronchiale afwijkingen) reden kan zijn voor langdurig ziekteverzuim, speelt vermoedelijk de opleiding van de patiënt ook een rol. Vermoedelijk bezit de $\mathrm{vg}$ en de ba/vg minder overtuigings- en overredingskracht ingeval van een gering of geen verschil in opleiding tussen patiënt en arts. De patiënt op zijn beurt zal meer invloed op de beslissing van de $\mathrm{vg}$ of ba/vg kunnen uitoefenen, zeker als de $\mathrm{vg}$ of ba/vg aanstuurt op werkhervatting en de patiënt daarentegen juist streeft naar titstel van werkhervatting.

* De bedrijfsgerichte taakopvatting toont in alle diagnosegroepen een samenhang met een korte ao-duur. Of anders gezegd: hoe geringer de afstand tussen de arts en het bedrij? is, des te geringer is de kans op een langerdurend verzuim.

* Eveneens bestaat er in de onderzoekspopulatie bij de diagnosegroep: alle diagnosen, een samenhang tussen een kortere ao-duur en de arts-variabelen: een groot 
aantal collega's in de werkomgewing van de arts, een groot aantal spreekuurpatiën ten en het volgen van bij-en nascholing. Wellicht hangt dit samen met de ruimere mogelijkheden tot intercollegiaal overleg, de werkervaring en een relatief professionele houding van de arts. Voor de groep; overige diagnosen, blijkt de richting van dit verband echter ongekeerd in de zin dat genoemde arts-variabelen samenhangen met een langere ao-duur. De verklaring is vermoedelijk gelegen in de objectiveerbaarheid en ernst van deze ziekten. Het gaat hier om hart- en vaatziekten, ziekten van de ademhalingswegen en ongevallen. Vermoedelijk zal bij deze ziekten zo niet al direct bij het optreden erwan, dan toch vrijwel zeker na 4 tot 8 weken arbeidsongeschiktheid de hulp van een specialist zijn ingeroepen. Deze relatief hoge mate van objectiveerbaarheid alsmede de verzuimlegitimatie, die uitgaat van de inschakeling van een specialist verklaren vermoedelijk de samenhang met een relatief lange arbeidsongeschiktheidsduur.

\subsubsection{De multiple regressie-analyse}

Met behulp van de multiple regressie-analyse is onderzocht welke factoren cq. variabelen invloed hebben op de ao-duur en of deze invloed verlengend of verkortend is. Bij deze analyse is gebruik gemaakt van arts- en patiëntvariabelen.

De arts-variabelen vertegenwoordigen de volgende aspecten:

* categorie arts: vg of ba/vg;

* omvang van de dienst, waarbinnen de arts werkzaam is: aantal arts-collega's;

* de werkwijze en werkervaring: duur dienstverband en aantal su-patiënten;

* de mate van professionalisering: deelname aan intercollegiale toetsing en het volgen van bij- en nascholing;

* de werkbeleving en taakopvatting: de tevredenheid met het werk en de gerichtheid op het individu (controlerend-begeleidend), het bedrijf (reïntegrerend) en de groep (preventief-analyserend).

De patiënt-variabelen vertegenwoordigen de volgende aspecten:

* gezondheid: het radplegen van een specialist en de leeftijd van de patiënt;

* aard en inhoud van het werk: de zwaarte van het werk en het opleidingsniveau.

De multiple regressie-analyse is uitgevoerd met de individuele variabelen: de zogenaamde stapsgewijze multiple regressie-analyse, en met behulp van groepen variabelen, die één der bovenstaande aspecten vertegenwoordigen: de zogenaamde groepsgewijze multiple regressie-analyse.

De stapsgewijze multiple regressie-analyse levert als meest in het oog springende bevinding de grote invloed, die arts-variabelen hebben op de ao-duur (tabel 5.27). Dit geldt voor de diagnosegroepen: alle diagnosen, psychische ziekten, ziekten wan het bewegingsstelsel en overige diagnosen (ziekten van de ademhalingswegen, ziekten van 
het hart-en watstelsel en ongevallen). Alleen bij deze laatste diagnosegroep blijken de patiènt-variabele: het raadplegen van een specialist, een significante relatie met de aoduut te hebber. De arts-gebonden variabelen, die een samenhang hebben met de aoduur, hebben dit in de richting van werkoring van de ao-duur. Dit betreft de volgende variabelen:

* de hoge mate van het op het bedrijf en de reïntegratie gericht zijn van de arts;

* een groot antal spreekuurpatiènten;

* cen groot aantal collega's, en

* een hoge mate van bij- en nascholingsactiveiten.

Dit betekent, dat naarmate de kennis van de arts groter is, er meer afstemmingsmogelijkheden bestaan met collega's en veel op het bedrijf gerichte reïntegratieactiviteiten ontplooid worden, de kans op een kortere ao-duur groter lijkt.

Dit is opmerkelijk, daar vg'n en ba/vg'n, gevraagd naar de verklaring van het hoge verzuim, grote en vaak owerheersende invloed toekennen aan buiten hen gelegen factoren als het de aard en zwaarte van het werk, de werkomstandigheden en de interventies van de curatieve sector. De invloed van de curatieve sector is alleen significant bij de diagnosegroep: overige diagnosen, en is verzuimverlengend. Dit verzuimverlengend effect kan een gevolg zijn van:

* de verzuimlegitimatie, die uitgaat van een verwijzing naar een specialist en het opvolgen van de adviezen van de specialist.

* de ernst en duur van de ziekte, die een verwijzing naar een specialist tot gevolg heeft.

In de praktijk zullen zowel de ernst van de ziekte als de wens van de patiënt tot legitimatie van het verzuim leiden tot het raadplegen van een specialist en een relatief lange ao-duur.

De groepsgewijze mra is uitgevoerd met de hiervoor genoemde groepen variabelen. De volgorde, waarin de variabelen in de mra zijn ingevoerd, is bepaald door de vraagstelling van het onderzoek. Allereerst zijn de arts-variabelen (organisatie, werkwijze, professionalisering, taakopvatting/werkbeleving) in de mra ingevoerd, daarna de patiënt-variabelen (gezondheid en kenmerken van het werk). De gezondheidsvariabelen hebben bij de 149-populatie een significante relatie met de ao-duur, indien ze eerder in de mra worden ingevoerd. Dit is zichtbaar in de bevindingen van de in paragraaf 5.4.4 beschreven multiple regressie-analyse. 
Tabel 5.27 Multiple regressie-analyse, stapsgewijs: samenhang tussen wariabelen en wowdunr, onderzoekspopulatie $(\mathrm{p} \leq 0.05$ )

+ betekent ao-duur verlengend

- betekent ao-duur verkortend

\begin{tabular}{|c|c|c|c|c|}
\hline & alle diagnosen & $\mathrm{vg}_{\mathrm{g}}$ & $\begin{array}{l}\text { z. v. bewa- } \\
\text { gingsstelsell }\end{array}$ & $\begin{array}{l}\text { overige } \\
\text { diagnosen }\end{array}$ \\
\hline $\begin{array}{l}\text { organisarie } \\
\text { groot aantal arts-collega's }\end{array}$ & - & - & - & \\
\hline $\begin{array}{l}\text { werkwize } \\
\text { groot aantal su-patienten }\end{array}$ & - & - & & - \\
\hline $\begin{array}{l}\text { professionalisering } \\
\text { veel bij- en nascholing }\end{array}$ & - & - & & - \\
\hline $\begin{array}{l}\text { vakopwating } \\
\text { bedrijfs-wg }\end{array}$ & - & & - & - \\
\hline $\begin{array}{l}\text { gezondheid patient } \\
\text { specialisil geraadpleegd }\end{array}$ & & & & + \\
\hline
\end{tabular}

Tabel 5.28 Multiple regressie-analyse, samenhang tussen groepen variabelen en an-duur, onderzoekspopulatie $(\mathrm{p} \leq 0.05)$

* betekent samenhang met een lange aom duu"

- betekent samenhang met een korte ao-duur

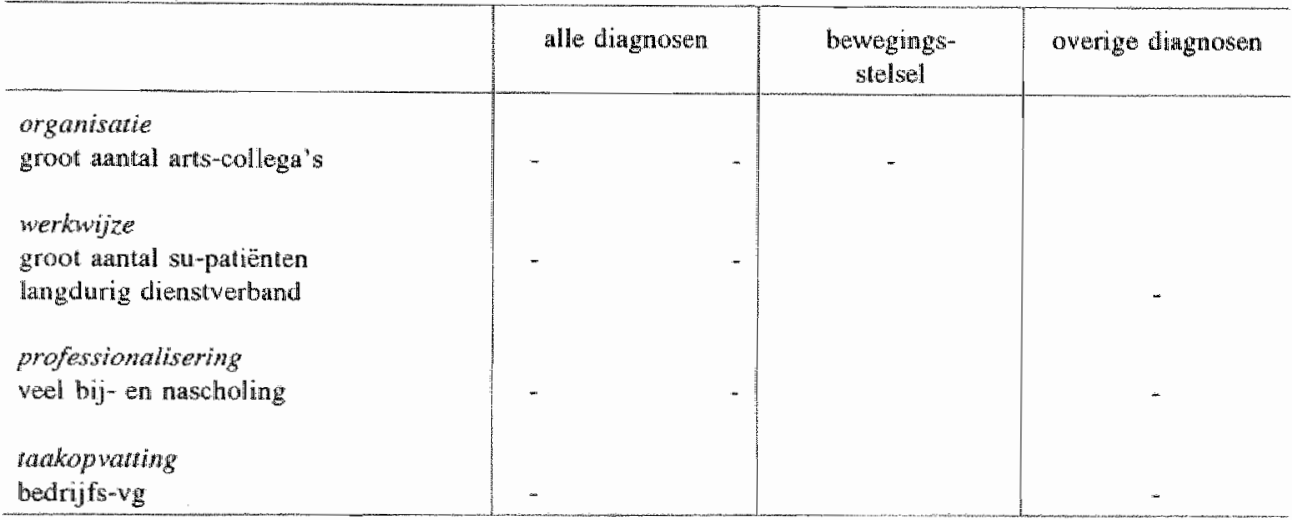

De resultaten van de multiple regressie-analyse met behulp van groepen variabelen in een vastgestelde volgorde komen in hoge mate overeen met de resultaten van de stapsgewijze multiple regressie-analyse. In tabel 5.28 zijn de significante relaties en de richting van hun invloed op de ao-duur van de groepsgewijze multiple regressie-analyse weergegeven. Voor op één na alle diagnosegroepen van de onderzoekspopulatie geldt, dat uitsluitend de arts-variabelen een samenhang hebben met de ao-duur. Dit betreft de groepen variabelen: organisatie, werkwijze, professionalisering en taakopvatting. Ook hier is er sprake van een samenhang tussen een relatief korte ao-duur en veel 
collega-artsen in de werkomgeving, een groot aantal spreekuurpatienten, het veelvuldig volgen van bij-en nascholing en de arts, die zich sterk richt op het bedrijf en de reintegratie van de patiënt.

De diagnosegroep: overige diagnosen, van de onderzoekspopulatie evenwel toont op het kenmerk: werkwijze, een afwijkend beeld: niet een groot aantal su-patiënten, maar een langdurig dienstverband wan de $\mathrm{vg}$ of ba/vg blijkt samen te hangen met een korte ao-duur.

De resultaten van de multiple regressie-analyse leveren een stevige ondersteuning van de stelling, dat er een samenhang is tussen een relatief korte arbeidsongeschiktheidsduur en een hoge mate van professionaliteit van de $\mathrm{vg}$ en ba/vg door meer bij- en nascholing, meer contacten tussen de artsen onderling door het vermijden van soloposten alsmede het werken vanuit een op het bedrijf gerichte taakopvatting. Uiteraard alleen, wanneer het realiseren van de reïntegratie van de patiënt in arbeid het doel van het handelen van de $\mathrm{vg}$ en ba/vg is. Wat het realiseren van reïntegraties betreft verkeert de $\mathrm{vg}$ in vergelijking met de ba/vg in een relatief ongunstige positie, zowel door het in vergelijking met de ba/vg grote aantal te begeleiden patiënten alsook door het grote aantal bedrijven en de daarmee samenhangende relatief grote afstand tot deze bedrijven. Toename van de mate van professionalisering en een directere relatie met het bedrijf kunnen een wezenlijke bijdrage leveren aan de reductie van het ziekteverzuim. 


\section{SLOTBESCHOUWING: ONDERZOEKSRESULTATEN IN SOCIAAL-VERZEKERINGSGENEESKUNDIG PERSPECTIEF}

\subsection{Reikwijdte en beperkingen van het onderzoek}

In de eerste paragrafen van dit hoofdstuk worden de onderzoeksresultaten samengevat om op basis daarvan nader in te gaan op de consequenties voor het verzekeringsgeneeskundig handelen. Tevens worden de onderzoeksresultaten geplaatst in een maatschappelijk perspectief. Bij deze beschouwingen moeten een tweetal kanttekeningen worden geplaatst.

1. Het onderzoek heeft plaatsgevonden in de jaren $1986 / 1988$ in de regio Zuid-Limburg. Het beperkt aantal aan het onderzoek deelnemende artsen alsook de beperking van het onderzoek tot één regio, laten absolunt geldende conclusies niet toe.

2. Bij de opzet van het onderzoek staat het verzekeringsgeneeskundig handelen centraal. Patiëntkenmerken en werkkenmerken zijn geen onderwerp van onderzoek geweest. De conclusies met betrekking tot het verzekeringsgeneeskundig handelen mogen echter niet de indruk wekken dat patiëntkenmerken en werkkenmerken van minder belang zouden zijn.

Het onderzoek is vooral indicatief van karakter en bevat veel elementen, die nader onderzocht zullen moeten worden. Het verdient zeker aanbeveling om het verzekeringsgeneeskundig handelen en werkkenmerken in een onderzoek samen te brengen.

\subsection{Opzet en uitvoering van het onderzoek}

Het onderzoek is opgezet met het doel inzicht te krijgen in relatie tussen enerzijds de werkwijze van met verzekeringsgeneeskundige taken belaste artsen: de $\mathrm{vg}$ en ba/vg, en anderzijds de invloed van hun handelen op de arbeidsongeschiktheidsduur (ao-duur) van de door hen begeleide patiënten.

Hoewel er veel onderzoek is verricht naar oorzaken van het ontstaan en voortduren van arbeidsongeschiktheid, is nimmer expliciet onderzoek gedaan, gericht op verschillen in taakuitoefening van de $\mathrm{vg}$ en ba/vg en de invloed daarvan op de arbeidsongeschiktheidsduur. Gelet op de cruciale rol van de $v g$ en ba/vg bij het sanctioneren van verzuim en thet realiseren wan reintegraties in het arbeidsproces, is inzicht in het handelen van de $\mathrm{vg}$ en ba/vg alsook in het effect van hun handelen onontbeerlijk. De verzekeringsgeneeskundige werkzaamheden van de vg en ba/vg zijn in kaart gebracht. Hierbij is gebruik gemaakt van het aan Timmer (1985) ontleende en aan de dagelijkse praktijk aangepaste verzekeringsgeneeskundig referentiekader. Het antwoord op de vraag: welke handelingen verrichten $\mathrm{vg}^{\prime \prime} \mathrm{n}$ en ba/vg'n en wat is het effect van hun handelen op de ao-duur, is onvolledig als niet tevens de taakopvattingen van de artsen 
in kaart worden gebracht. Immers, de wijze, waarop zij denken over hun werk en hun werk beleven, is van invloed op hun takkuitvoering en de door hen te leveren prestatie. Eèn van de vraagstellingen betreft dan ook de vraag: hoe kijken vg'n en ba/vg'n zèlf tegen hun werk aan. Bij de opzet van dit deel van het onderzoek is onder andere gebruik gemaakt van onderzoek naar taakopvattingen bij huisartsen (Boots, 1983) en onderzoek naar de taakuitoefening door vg'n (GAK, 1986).

Besloten is nader onderzoek te verrichten naar de verschillen in taakopvattingen tussen $\mathrm{vg}^{\prime} \mathrm{n}$ en ba/vg'n; Bij deze vergelijking is ook de ba meegenomen. De taakopvattingen van en de verschillen in taakopvatting tussen $\mathrm{vg}$, ba/vg en ba zijn in kaart gebracht en beschreven.

De registratie van de artsgegevens is geschied door middel van gestructureerde interviews wan alle aan het onderzoek deelnemende artsen. Hierbij werd gebruik gemaakt van een standaardvragenlijst.

De taakopvattingen zijn in kaart gebracht door het door de $\mathrm{vg}$, ba/vg en ba laten waarderen van een 68-tal stellingen en uitspraken op een vijfpuntsschaal van eens tot oneens.

De begeleidingsactiviteiten en oordeelsvorming van de $\mathrm{vg}$ is in kaart gebracht door de $v g$ en ba/vg na iedere spreekuurbeoordeling een vragenlijst te laten invullen.

De informatie over de patiënt is verzameld door de voor het onderzoek geselecteerde patiënten een vragenlijst uit te reiken met het verzoek deze zo spoedig mogelijk ingevuld in te zenden.

\subsection{Taakopvattingen: resultaten en conclusies}

In deze paragraaf worden de resultaten en conclusies van het onderzoek naar de taakopvattingen van $\mathrm{vg}^{\prime} n$, ba/vg'n en ba'n beschreven.

Met behulp van een 14-tal taakopvattingsclusters zijn de vg, ba/vg en ba naar takopvatting te onderscheiden. De taakopvattingen van de $\mathrm{vg}, \mathrm{ba} / \mathrm{vg}$ en ba blijken aanzienlijk uiteen te lopen.

De $\mathrm{vg}$ is vooral op de sturing van de patiënt gericht. Hierbij staat de formele taak en de wetsuitvoering voorop. De $\mathrm{vg}$ hecht geringe waarde aan het bestaan van een vertrouwensrelatie en richt zich vanuit een ruime opvatting ten aanzien van de taakomvang op de omgeving van de patiẻnt. Bij de reïntegratie heeft de $\mathrm{vg}$ in mindere mate behoefte an informatie vanuit het bedrijf. De $\mathrm{vg}$ kan op basis van zijn opvattingen als een sturings(raak)gerichte arts worden beschouwd.

De ba/vg is vooral op de omgeving gericht; hieronder worden zowel groepen patiënten als het bedrijf verstaan. Vanuit deze ongevingsgerichtheid is hij geïnteresseerd in de preventie. Vanuit deze taakopvatting hecht hij veel waarde aan de relatie met patiënten, het bedrijf en de curatieve sector. De ba/vg kan gekarakteriseerd worden als relatiegericht. 
De ba richt zich vooral op het bedrijf en is erg op resultaat gericht. De ba acht de middelen om zijn doel te bereiken te beperkt. Zijn invalshoek is de preventie. Zijn opvatting over de takomvang is beperkter dan die van de vg en ba/vg. De ba identificeert zich meer met de bedrijfsgezondheidszorg dan met de verzekeringsgeneeskunde. De ba kan op basis van de takkopvattingen gekarakteriseerd worden als bedrilfsgericht.

De taakopvattingen van $\mathrm{vg}$, ba/vg en ba zijn, zoals uit het voorgaande blijkt, duidelijk te onderscheiden. De vg en ba blijken het sterkst te verschillen. Vermoedelijk spelen zowel eigen opvattingen alsook de cultuur van de organisatie, waarbinnen de vg en $\mathrm{ba} / \mathrm{vg}$ werken, een rol. Hier ligt dan ook een aangrijpingspunt: veranderingen in taakopvatting kunnen door cultuurveranderingen binnen de uitvoeringsorganisaties mede tot stand worden gebracht.

Op grond van verdere factor-analyse zijn uiteindelijk drie taakopvattingsvariabelen gekozen: bedrijfsgericht, individugericht en groepsgericht.

Onder bedrijfsgericht wordt verstaan de mate waarin artsen zich sterk richten op de reintegratie en daarbij sterk anticiperen op de omgeving van de patiënt, het bedrijf en de curatieve sector.

Vanuit deze bedrijfsgerichte taakopvatting stelt de arts zich actief op naar patiënt en bedrijf en tracht dié maatregelen te nemen, die een reïntegratie in werk bevorderen.

Onder individugericht wordt verstaan de mate waarin artsen zich sterk richten op de begeleiding van de individuele patiënt; ten behoeve van deze begeleiding wordt de coördinatie met de curatieve sector van belang geacht. Vanuit deze individugerichte taakopvatting zal de vg of ba/vg zich meer controlerend opstellen en zich minder inlaten met het werk en de werkomgeving van de patiënt. Hij richt zijn aandacht meer op de ziekte dan op de arbeidsongeschiktheid.

Onder groepsgericht worden verstaan de mate warin artsen zich sterk op de groepsbenadering richten. Vanuit deze groepsgerichte takkopvatting zal de arts zich relatief meer met de preventie dan met de begeleiding of reïntegratie bezighouden. Een arts met deze taakopvatting is relatief minder op resultaat in de zin van werkhervatting gericht.

Deze drie taakopvattingen zijn als onafhankelijke variabelen meegenomen bij de verklaring van de verschillen in arbeidsongeschiktheidsduur (ao-duur).

Uiteraard is eveneens onderzocht in hoeverre deze taakopvattingsvariabelen een onderscheidend vermogen hebben naar de categorie arts: $\mathrm{vg}$, ba/vg en ba. Alleen de taakopvattingsvariabele bedrijfsgericht maakt een significant onderscheid tussen $\mathrm{vg}$, ba/vg en ba.

\subsection{Verschillen in begeleiding tussen verzekeringsgeneeskundige en bedrijfsarts/verzekeringsgeneeskundige}

In deze paragraaf worden de resultaten en conclusies wan het onderzoek naar de verschillen in begeleiding en arbeidsongeschiktheidsduur tussen $\mathrm{vg}$ en ba/vg (par. 6.4.1) 
duur apart onderzocht. Vervolgens is de samenhang tussen organisatie-, arts- en palientvariabelen en de verzumdur onderzocht.

In de onderzokspopulatie bestaat er een sterke samenhang wssen de verzuimduur en de wachtijd. Deze samenhang kan samenhangen met zowel de regelgeving van de uitvoeringsorganisaties als de emst van de ziekte van de patiênt. Op basis van de regelgeving zal - door inschakeling van een lekencontroleur - het eerste contact tussen patient en $\mathrm{vg}$ of $\mathrm{ba} / \mathrm{vg}$ in het algemeen pas na enige tijd tot stand komen. Een ernstige ziekte zal veelal leiden tot interventie van een curatieve arts. Dit leidt er toe dat een snelle verzekeringsgeneeskundige interventie niet noodzakelijk wordt geacht of, bijvoorbeeld in geval van opname in het ziekentwis niet mogelijk is. Verwacht mag worden, dat met name het doorbreken van de regelgeving door een snelle eerste spreekuurbeoordeling een werkortend effect op de ao-duur zal hebben.

De belangrijkste factoren, die in dit onderzoek gemeten zijn en die de verzuimduur beinvloeden, zijn gelegen bij de positie van de arts. Een groot aantal collega-artsen op de werkplek van de vg en ba/vg, een groot aantal sumpatiẻnten, een hoge mate van professionaliteit (intercollegiale toetsing, bij- en nascholing) én de taakopvatting van waar-wit op het bedrijf gerichte reintegratie-activiteiten worden ontplooid, hebben een sterke samenhang met een kortere ao-duur. Of anders gezegd, naarmate er meer mogelijkheden op de werkplek van de $\mathrm{vg}$ en ba/vg bestaan tot toetsing van het eigen beleid, de vg en ba/vg meer ervaring en kennis bezitten en deze door bij-en nascholing op peil kunnen houden of verbreden en de $\mathrm{vg}$ en $\mathrm{ba} / \mathrm{vg}$ vanuit een bedrijfsgerichte taakopvatting werken aan de reintegratie wan de patiënt, zal de gerealiseerde verzuinduur korter zijn.

Tegen de achtergrond van wat bekend is uit de literatuur is dit een niet onbelangrijke constatering. De invloed van factoren als de arbeidssituatie (Smulders en Draaisma, 1978), de kwalliteit van de arbeid (Nijhuis en Soeters, 1982) en de gezondheidszorg (Buys, 1988) op thet ziekteverzuim is bekend. Vg'n en ba/vg'n ervaren deze factoren als nauwelijks of niet beïnvloedbaar en verklaren daarmee hun beperkte invloed op het ziekteverzuim. In de publicaties in de pers over het volumebeleid verwijzen artsen dan ook al te snel naar de rol van de werkgever en de afthankelikheid van de curatieve sector, wanneer zij aangesproken worden op het hoge ziekteverzuim in Nederland. Zij leiden tot een onderschatting van de eigen invloed op de verzuimduur en een misken ning van de mogelijkheid tot beinvloeding van de arbeidsongeschiktheidsduur. Immers, uit dit onderzoek blijkt, dat een hoge mate van professionaliteit, contact met de curatieve sector en een bedrijfsgerichte instelling leidt tot invloed uitoefenen op de arbeidssituatie en arbeidsomstandigheden en daling van het verzuim. Dit gevoegd bij de werkervaring betekent, dat $\mathrm{vg} n$ en ba/vg"n wel degelijk invloed kunnen uitoefenen op de verzuinduur.

Van de patientkenmerken is uitsluitend de vraag of een patiënt een specialist geraadpleegd heeft gerelateerd aan de verzuimduur. 
Het raadplegen van een specialist hangt samen met een langere ao-duur. Dit verzuimverlengend effect kan een gevolg zijn van:

* de verzuimlegitimatie, die uitgaat van een verwijzing naar een specialist en het opvolgen van de adviezen van de specialist. Zowel de patiënt als de vg of ba/vg kunnen een verwijzing naar en behandeling door een specialist gebruiken als verzuimlegitimatie.

* de ernst en duur van de ziekte, waarvan een verwijzing naar een specialist het logisch gevolg is.

In de praktijk zullen zowel de ernst van de ziekte als de wens van de patiënt en arts tot legitimatie van her verzuim leiden tot het raadplegen van een specialist en een relatief lange ao-duur.

Verklaren de hiervoor genoemde variabelen de ao-duur in hoge mate en is de richting van hun invloed - ao-duur verkortend of verlengend bekend - ook bepaalde overige variabelen een samenhang vertonen met de ao-duur.

Bij de diagnosegroep: overige diagnosen, bestaat een samenhang tussen een langere aoduur en een hoog opleidingsniveau van de patiënt. Hoewel een hoog opleidingsniveau (van de patiënt) vermoedelijk samengaat met het verrichten van lichte lichamelijke arbeid en samenhangt met een korte ao-duur, bestaat bij de diagnosegroep: overige diagnosen (ziekten van het hart- en vaatstelsel/ademhalingswegen en ongevallen), juist een samenhang tussen een hoge opleiding en lange ao-duur. Wat het opleidingsniveau van de patiënt betreft: het is mogelijk dat hoger opgeleiden meer invloed kunnen uitoefenen op het beleid van de $\mathrm{vg}$ of ba/vg vanwege geen of gering verschil in opleidingsniveau. Voorts beschikken hoger opgeleiden in de regel door de aard van hun werk over meer mogelijkheden tot aanpassing van de werkdruk en werktempo. $\mathrm{Zij}$ zullen zich niet zo snel ziek behoeven te melden. Melden zij zich toch ziek, dan zal door het uitgeput zijn van de aanpassingsmechanismen een werkhervatting moeilijker te bereiken zijn. Deze twee mechanismen, die overigens niets zeggen over de arbeidsmotivatie, resulteren mogelijkerwijs in een langere ao-duur van deze groep patiënten.

De samenhang tussen een langere ao-duur en een korte duur van het dienstverband van de arts, wijst mogelijkerwijs op het ontbreken van ervaring bij de arts.

De belangrijkste constatering naar aanleiding van deze analyse is, dat artsgebonden factoren wel degelijk invloed hebben op de ao-duur. $\mathrm{Vg}$ en ba/vg blijken, overigens ten onrechte, een te grote waarde toe te kennen aan externe factoren als werk, werkomstandigheden en de interventies van de curatieve sector. Dit betekent, dat vg en $\mathrm{ba} / \mathrm{vg}$ hun werk en functioneren op een aantal punten moeten bijstellen:

1. Een snellere eerste spreekuurbeoordeling kan leiden tot een kortere ao-duur. Deze snellere eerste beoordeling dient dan niet zozeer gericht te zijn op de controleaspecten. Nadruk op controle, blijkend uit een meer individugerichte taakopvatting, heeft geen relatie met de ao-duur. Een vroegere start van de begeleidling en 
de reintegratie-acciviteiten vormen een voorwaarde voor het realiseren van een relatief korte ao-duur.

2. Een snellere eerste beoordeling ressorteert meer effect, indien de relatie tussen vg of ba/vg enerzijds en het bedrijf anderzjids intensiever en indringender is. De thans bestaande afstand tussen de $\mathrm{vg}$ en ba/vg en bedrijven vormt momenteel een forse belemmering voor de terugdringing van de verzuimduur. De vg verkeert in deze in ten veel ongunstiger positie dan de ba/vg. Het verdient aanbeveling de huidige werkwijze kritisch door te lichten en in bovengenoemde zin bij te stellen: er moet gestreefd worden naar een één op én relatie tussen arts en bedrijf.

3. Meer kennis over ziekten, werk en werkomstandigheden en hun onderlinge relaties stellen de vg in staat gerichter te begeleiden. Gezien de noodzaak de bestaande kennis op peil te houden en nieuwe kennis te verwerven, dient het volgen van bijen nascholing geen wrijblijwende zaak te zijn. Helaas is dat nu vaak het geval. De beroepsgroep danwel de uitvoeringsorganisatie, waar de $\mathrm{vg}$ en ba/wg werkzaam is, dienen bij- en nascholing verplicht te stellen. De samenhang tussen hoge mate van professionaliteit en een relatief korte ao-duur geeft hier alle aamleiding toe. De mogelijkheden om kennis en ervaring te toetsen aan en uit te wisselen met collega's dienen vergroot te worden door het stimuleren van intercollegiale contacten.

4. Artsen op soloposten bezitten in het algemeen weinig mogelijkheden hun beleid te toetsen aan dat van collega's en gebruik te maken van de kennis en ervaring van collega's. Het werken op een solopost, zonder collega-artsen in de directe werkomgeving, leidt tot een relatief lange ao-duur in wergelijking met vg"n en ba/vg'n, die op hur werkplek meer collega's aantreffen. Soloposten dienen dan ook zoveel mogelijk vermeden te worden.

\subsubsection{Samenvatting wan de resultaten}

$\mathrm{Vg}$, ba/vg en ba blijken te onderscheiden op basis van hun taakopvattingen. De vg is een sterk op de patiënt gerichte arts en houdt zich sterk aan de regels en procedures, zoals bepaald in de wet en door de regelgeving van de uitvoeringsorganisatie. Vanuit een formele opstelling zal de $\mathrm{vg}$ vooral controlerend begeleiden. De ba/vg richt zich vooral op de reintegratie van de patient en ten behoeve daarvan op het bedrijf. Daarnaast richt de ba/vg zich op de preventie. De ba is relatief sterker gericht op de preventie en is minder gericht op de controle en reintegratie in het werk.

Het onderscheid in taakopvatting is het grootst ussen vg en ba.

Overigens valt op basis van de taakopvattingen een duidelijk onderscheid te maken tussen enerzijds vg en ba/vg en anderzijds ba/vg en ba.

Tussen $\mathrm{vg}$ en ba/ $\mathrm{vg}$ bestaan grote verschillen in begeleidingsactiviteiten en gerealiseerde ao-duur. De vg start de begeleiding relatief latat, toont relatief weinig op het bedrift gerichte activiteiten en is somberder over de prognose ten aanzien van werkhervatting dan de ba/vg. De door de $\mathrm{vg}$ begeleide patiënten verzuimen in de regel langer 
dan de door de ba/vg begeleide patiënten. Een verklaring voor deze verschillen is niet uitsluitend te vinden in de werkwijze van de $\mathrm{vg}$, die mede onder invloed van de regelgeving van de uitvoeringsorganisatie niet altijd adequaat is ten aanzien van de ao-duurverkorting. Veeleer is dit een gevolg van de relatief grote afstand tot en de geringe kennis over het bedrijf. De $\mathrm{vg}$ heeft de zorg voor patiënten wit een (te) groot aantal bedrijven uit de meest uiteenlopende bedrijfstakken; de ba/vg daarentegen heeft enige tot maximaal tientallen bedrijven uit een beperkt aantal bedrijfstakken. Bovendien ontlenen vele bij een $\mathrm{BV}$-aangesloten bedrijven aan de verzekeringsvorm geen prikkel om actief aan reïntegraties mee te werken.

De factoren die de ao-duur verklaren blijken, een uitzondering daargelaten, artsgebonden factoren. Dit is opmerkelijk, daar gemeenlijk aan buiten de arts gelegen factoren, zoals het werk, de werkomstandigheden, de medewerking van het bedrijf alsook het ontbreken van voldoende sterke financiële prikkels voor de patiënt, een overheersend en niet te weerhouden verzuimbevorderend effect wordt toegekend. Een te verklaren relatie met een korte ao-duur hebben de onderstaande artsgebonden factoren:

- een groot aantal collega's op de werkplek van de vg. Vermoedelijk biedt dit de vg en ba/vg de mogelijkheid tot collegiaal overleg.

ervaring en routine van de $\mathrm{vg}$ of $\mathrm{ba} / \mathrm{vg}$ in het werk.

een hoge mate van professionalisering. Het regelmatig volgen van bij- en nascholing en het daardoor beschikken over actuele kennis over ziekten, therapieën en reïntegratiemogelijkheden.

- een taakopvatting, van waaruit de $\mathrm{vg}$ of $\mathrm{ba} / \mathrm{vg}$ zich richt op de reïntegratie van de patiënt en het bedrijf hierbij betrekt.

De taakopvatting, van waaruit de $\mathrm{vg}$ zich sterk richt op de controle van de individuele patiënt heeft geen enkele samenhang met de ao-duur; deze samenhang met een langere ao-duur bestaat wel voor de, en dan vooral analyserend, op preventie gerichte $\mathrm{vg}$ of $\mathrm{ba} / \mathrm{kg}$.

\subsection{De maatschappelijke relevantie}

Meer dan ooit tevoren staat het hoge ziekteverzuim en het grote aantal arbeidsongeschikten in het middelpunt van de belangstelling. Naast de bezorgdheid over de kosten, die resulteren uit ziekteverzuim en arbeidsongeschiktheid, bestaat er grote bezorgdheid over de toenemende scheefgroei tussen het aantal inactieven en actieven. Onder deze unactieven rekent man niet alleen de arbeidsongeschikten, maar ook de werklozen en bijstandtrekkers. Het ontstaan van een tweedeling in de maatschappij - actieven en niet actieven - is een weinig aantrekkelijk perspectief. Ook de komende Europese eenwording, die op langere termijn mogelijkerwijs leidt tot een integratie van de verschillende nationale sociale wetgevingen, vraagt nu reeds om aanpassingen van de sociale verzekeringswetten. De aantrekkelijkheid en toegankelijkheid wan de regelingen in de verschillende Europese landen zullen op een gelijker niveau moeten worden gebracht om een ongewenste groei wan het gebruik van de sociale verzekeringen in Nederland te 
voorkomen. Om de concurrentiepositie van het Nederlandse bedrijfsleven op Europees niveau in stand te houden is het gewenst de hoogte van de sociale verzekeringspremies (en lonen) op een min of meer gelijk niveau te houden met de ons omringende landen. Met name is dit laatste voor werkgevers een belangrijk argument om het ziektevercuim en het grote aantal arbeidsongeschikten terug te dringen. Op dit moment zijn maatregelen, die ingrijpen op de uitkeringshoogte en uitkeringsduur van de ziektewet en de WAO in voorbereiding of in uitvoering. Hieronder vallen financiële stimulansen voor werkgevers en werknemers om het ziekteverzuim terug te dringen en de instroom WAO te verminderen, meer mogelijkheden voor aangepast werk en intensivering van de reïntegratieactiviteiten van de uitvoeringsorganisaties. Vanuit de uitvoeringsorganisaties bestaat daarnaast in toenemende mate aandacht voor preventie; het is tenslotte beter arbeidsongeschiktheid te voorkomen dan op te heffen. Het besluit van de uitvoeringsorganisaties GAK en GMD tot integratie kan vanuit deze doelstellingen verklaard worden.

Het volumebeleid - het terugdringen van het ziekteverzuim en het verminderen van het aantal arbeidsongeschikten - krijgt thans op een tweetal manieren vorm:

1. Verkleining van de kans op arbeidsongeschiktheid en vergroting van de mogelijkheden tot herinpassing in arbeid. Door middel van aanpassingen in de bestaande wetgewing en invoeren van nieuwe wetten (bijv, voorontwerp van wet Terugdringing Arbeidsongeschiktheidsvolume-TAV, Terugdringing Ziekteverzuim-TZ) worden maatregelen voorbereid, die zich richten op werkgevers, werknemers en uitvoeringsorganisaties. Deze maatregelen beogen een verbetering van werkomstandigheden, een verkleining van uitvalkans (preventie) en vergroting van mogelijkheden tot aanpassing van arbeid en arbeidsomstandigheden.

2. Verbetering van de efficiency en effectiviteit van de uitvoeringsorganisaties sociale verzekeringen, onder andere door aampassingen van de Organisatiewet Sociale Verzekeringen, veranderingen in de taken en bevoegdheden van de Federatie van Bedrijfsverenigingen (FBV) en de Sociale Verzekeringsraad (SVR) en de integratie van GAK en GMD.

Onvermijdelijk rijst hierbij de vraag welke bijdrage de sociaal-medische begeleiding kan leveren aan een volumebeleid. In het midden van de tachtiger jaren stond ten aanzien van de opvang van de stijging van het ziekteverzuim en het toenemend aantal langdurig arbeidsongeschikten de vraag centraal of de sociaal-medische begeleiding in deze kon worden verbeterd. Aan de Nationale Raad voor de Volksgezondheid werd advies gevraagd over een drietal modellen: het huisartsenmodel, het verzekeringsgeneeskundig model en het uitgebreid verzekeringsgeneeskundig model. Onder dit laatste werd verstaan de bundeling van bedrijfs- en verzekeringsgeneeskundige kennis in één arts. Kenmerk van al deze modellen is dat de coördinatie van behandeling en begeleiding bij éen arts gelegd wordt.

De vraag naar verbetering van de sociaal-medische begeleiding heeft tot op heden niets van haar maatschappelijke relevantie verloren. Vanuit de wens tot verbetering van de sociaal-medische begeleiding ten behoeve van de volumebeheersing is het van het 
grootste belang inzicht te hebben in de rol van de met verzekeringsgeneeskundige taken belaste arts en de invloed hiervan op de arbeidsongeschiktheidsduur. Daar komt bij, dat in het Najaarsoverleg 1990 tussen werkgevers, werknemers en overheid naatregelen zijn overgekomen gericht op een intensivering van de gevalsbehandeling: een snellere en betere verzekeringsgeneeskundige begeleiding. Maar welke aspecten met betrekking tot deze begeleiding moeten sneller en welke moeten beter? of anders gezegd: op welke wijze kunnen de met verzekeringsgeneeskundige taken belaste artsen hun activiteiten zodanig inrichten, dat het leidt tot een beperking van ziekteverzuim en arbeidsongeschiktheidsduur? Dit onderzoek heeft door middel van onderzoek onder artsen, die vanouds betrokken zijn bij de beoordeling en/of begeleiding van arbeidsongeschikten: de $v g$ en de ba/vg, getracht een antwoord te geven op de volgende vraag: welke factoren en omstandigheden betreffende de arts, de uitvoeringsorganisaties, de patiënt en het bedrijf hebben een verlengende danwel verkortende invloed op de arbeidsongeschiktheidsduur?

De uitkomsten van dit onderzoek bevestigen de belangrijke rol die de vg en ba/vg vervult als bewaker van de toegang tot de regelingen/voorzieningen ingevolge de sociale verzekeringen, in het bijzonder de ZW en in het verlengde hiervan de WAO. Wat de diagnostiek betreft zijn er geen verschillen tussen $\mathrm{vg}$ en ba/vg. De verschillen tussen de werkwijzen van beide tekenen zich af in de reïntegratie-activiteiten en hun samenwerking met het bedrijf. Deze twee elementen zijn niet los van elkaar te zien. Zij resulteren in een grotere kans op langdurige ao-heid van door de vg begeleide patiënten.

De grootste handicap voor de vg vormt het grote aantal bedrijven, waarmee hij te maken heeft. Dit belemmert de $\mathrm{vg}$ in het opdoen en onderhouden van specifieke kennis over een bedrijf of een bedrijfstak. Dit leidt ertoe dat gerichte reïntegratieactiviteiten in samenwerking met het bedrijf niet of nauwelijks gerealiseerd kunnen worden.

Daarnaast leidt de heersende regelgeving van de uitvoeringsorganisaties vaak tot het inschakelen van lekencontroleurs, waardoor de interventie van de $\mathrm{vg}$ of ba/vg onnodig laat start.

Verklarend bleken de artsgebonden factoren, welke op een uitzondering na namelijk: individu-gerichte taakopvatting wan de $\mathrm{vg}$, een samenhang met de ao-duur blijken te bezitten.

Wat kunnen vg"n en uitvoeringsorganisaties doen ter beperking van het ziekteverzuim? Op grond van dit onderzoek kunnen de volgende aanbevelingen geformuleerd worden:

1. een snellere interventie van vg en ba/vg is noodzakelijk. Naast een adequatere toegangsbewaking tot de $\mathrm{ZW}$ biedt dit tevens de mogelijkheid eerder to starten met reïtegratie-activiteiten en resulteert in een kortere ao-duur. In dit verband verdient het aanbeveling te onderzoeken in hoeverre de thans vigerende wetgeving (bijvoorbeeld Ziektewet, ARBO-wet, WAGW) voldoende mogelijkheden tot reïntegratie bieden. 
2. Gegeven de positieve bijdrage aan de ao-duurverkorting van het werken met meerdere collegae op een werkplek van $\mathrm{vg}^{\prime} \mathrm{n}$ en ba/vg'n dienen soloposten zo veel mogelijk te worden vermeden.

3. Zowel voor $\mathrm{vg}$ als ba/vg is het op peil houden van de vakinhoudelijke dat wil zeggen algemeen medische en verzekeringsgeneeskundig alsook arbeidskundige kennis middels het periodiek volgen van bij- en nascholing onmisbaar. Aangezien de beroepsgroep nascholing (nog) niet verplicht stelt, zullen de uitvoeringsorganisaties zorg moeten dragen voor een regelmatige bij- en nascholing.

4. De relatie tussen vg en ba/vg en bedrijf is van grote invloed op de ao-duur van de verzorgde populatie. De $v g$ verkeert wat dat betreft in een relatief ongunstige positie. De vg heeft met zoveel bedrijven te maken, dat specifieke kennis over bedrijven en/of bedrijfstakken niet tot stand kan komen, laat staan in stand kan worden gehouden. Tevens zullen door de relatief grote afstand tussen bedrijf en vg de reïntegratiemogelijkheden onvoldoende onderkend en benut kunnen worden.

De beoordeling wan arbeidsongeschikten (toegangsbewaking) alsook de begeleiding naar werkhervatting wordt bij ontbreken van voldoende specifieke kennis over het bedrijf, de arbeid en de arbeidsomstandigheden sterk bemoeilijkt.

De relatie vg - bedrijf behoeft indringend een verandering om een vergroting van de kennis over bedrijfstakken en de reïntegratiemogelijkheden binnen bedrijven mogelijk te maken. Dit kan bereikt worden door vg'n in te zetten ten behoeve van bepaalde bedrijven of bedrijfstakken. De door de $\mathrm{vg}$ (en ba/vg) verzorgde patiëntenpopulatie bestaat in een dergelijke situatie uit bedrijfspopulaties.

Binnen de uitvoeringsorganisaties is indertijd om redenen van efficiency gekozen voor geografische rayons; d.w.z. de vg ontvangt zijn patiënten uit een bepaald gebied (regio, stad). Voordelen van deze werkwijze zijn een voor de patiënt relatief geringe reisafstand naar de uitvoerende instantie i.c. de $\mathrm{vg}$ en wat de $\mathrm{vg}$ betreft geringe reistijden bij huisbezoeken. Op dit moment is er sprake van een tendens de $v g$ te koppelen aan bedrijven. Het vervangen van geografische rayons door be-

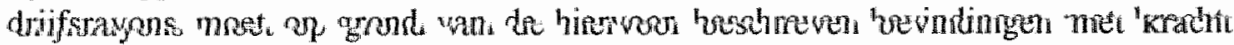
worden bevorderd en is voorwaardelijk voor het realiseren van een volumebeleid: beheersing en beperking van het ziekteverzuim en langdurige arbeidsongeschiktheid en de kosten van de sociale verzekeringen.

Uiteraard staan tegenover de voordelen ook nadelen. Een belangrijk nadeel is het minder efficiënt kunnen inzetten van artsen en anderen door vergroting van het geografische werkgebied (afhankelijk van de woonplaats van de patiënten). Dit zal resulteren in minder patiënten per arts en ten gevolge hiervan een stijging van de uitvoeringskosten. Indien echter een substantiële daling van het ziekteverzuim optreedt en deze daling zich vervolgens vertalt in lagere premies voor werkgevers en werknemers, kunnen ondanks een stijging van de uitvoeringskosten de totale kosten van de sociale verzekeringen dalen. Een vervolgonderzoek zal zich dan ook 
niet mogen beperken tot het verzekeringsgeneeskundig handelen, maar zal ook de effecten op de omvang van de uitkeringen en premies moeten omvatten.

5. De vg en ba/vg zijn in hoge mate afhankelijk van de medewerking van de werkgever bij het realiseren van reintegraties. Het huidige premiestelsel bevat voor vele werkgevers onvoldoende financiële prikkels actief mee te werken aan reintegraties. Vervolg onderzoek zal zich dan ook moeten uitstrekken tot de vrag hoe binnen het premiestelsel effectieve prikkels tot verzumbeperking kunnen worden opgenomen.

Deze conclusie sluit nauw aan bij de maatregelen, zoals afgesproken in het overleg tussen de sociale partners (werknemers, werkgevers en overheid (Najaarsoverleg 1990). Deze maatregelen richten zich op een versnelling en intensivering van de begeleiding door vg'n en ba/vg'n en het betrekken van de werkgever bij de reintegratie met als doel een betere beheersing en beperking van het ziekteverzuim en het aantal langdurig arbeidsongeschikten. Op basis van de resultaten van dit onderzoak moet een snellere interventie van de $\mathrm{vg}$ of ba/vg en een intensievere relatie met werkgevers met kracht worden nagestreefd. 


\section{SUMMARY}

In 1990 sickness absenteeism is one of the major political and economical problems in the Netherlands. An average sickness absenteeism-percentage of 8.5 and nearly 900.000 long-termed disabled people reveal the problem in its sharpest form. Laws concerning sickness absenteeism and disabled (Sickness Insurance Act and the Disability Benefits Act) are executed by the Social Security Institutions, that determine whether or not an employee can be declared able to return to work. This study presents the results of a study concerning the functions and activities of the doctors of the Social Security Institutions and the relation between their taskperceptions and activities and the duration of sickness absenteeism.

The origin of this study is described in chapter 1. The most important starting point is to be found in the policy of the Dutch Government to reduce sickness absenteeism and the number of disabled.

Since the mid fifties intensive research into the origin of sickness absenteeism has been published. Nevertheless, the role of the social insurance-doctors has never been investugated, allthough several studies have appeared in which some aspects of their work have been covered. Relevant studies concerning this problem are described in chapter 2. In the Netherlands are two types of social insurance-doctors:

1. the social-insurance doctors of the Social Security Institutions (Bedrijfsverenigingen), that determine whether or not an employee can be declared able to return to work and perform all kind of measures regaining ability for work, and

2. occupational health-doctors, that perform also the task of the social insurance-doctor. These doctors are in general employees of an company or employer.

This study is based on the Dutch situation. The differences between Social Security Systems in the European countries makes comparison nearly impossible. The position of the social insurance-doctor in the Netherlands has two distinguishing caracteristics:

1. an uncoupling of care/cure and the sanctioning of sickness absenteeism, and

2. an uncoupling of Occupational Health Services and Social Security Institutions.

For this reason comparision with taskperception and taskfull-fillment of doctors in other countries is nearly impossible; usable international literature on this subject is limited.

The probllem is placed in the framework of the relevant literature in chapter 2 and concerns:

1. Which activities have social insurance-doctors (sid) and occupational health-/social insurance-doctors (ohd/sid) developed in the context of control and counselling?

2. Do differences exist in the type of activities and taskperception between these two groups of doctors? 
3a. Do the differences in the duration of sickness absenteeism depend on the taskperceptions and activities of the sid and ohd/sid?

$3 b$. Do the differences in the duration of sickness absenteeism depend on the type of organization in which the sid and ohd/sid do their work?

The research design and the manner in which it was executed are described in chapter 3. The activities of 35 social-insurance doctors were recorded during the "treatment" of 482 patients from the second till the ninth month of absenteeism.

\section{The taskperceptions}

As described in chapter 4 the questionnaire concerning the taskperceptions was not only presented to 35 social-insurance doctors (sid and ohd/sid), but also to 16 doctors of the Occupational Health Services (ohd).

Using 14 clusters of taskperception the sid, ohd/sid and ohd can be differentiated as to total taskperception.

The taskperception of the sid is mainly directed at observing the laws and have as object the individual. The existence of a relation of trust between patient and sid is seen to be important. The sid is also strongly interested in the environment of the patient. The relation with the company or employer, also for the purpose of reintegration, is seen as less important. The sid can be characterized as a patient-oriented doctor, working with formal rules.

The taskperception of the ohd/sid appeared to be strongly oriented towards the environment of the patient. He is interested in the company for which the patient is working and aims at prevention. The ohd/sid addresses relatively more groups of patients. The relation with patients, companies and the curative sector is important for the ohd/sid. The ohd/sid can be characterized as a rellation-oriented doctor.

The taskperception of the ohd is company oriented with the emphasis on prevention. Due to the fact that he is strongly result-oriented he considers the means he can employ as too limited. The ond can be characterized as a company-oriented doctor.

The largest difference exists between the taskperceptions of the sid en ohd, by which basis they can be correctly differentiated in $97 \%$ of the cases. This is not surprising, the tasks of the sid and ohd are completely different. The ohd has a company-medical, not an insurance-medical task. The sid has exclusively an insurance-medical task. On the other hand the ohd/sid fulfills both tasks: company-medical and insurance-medical. The difference between sid - ohd/sid and ond/sid - olad is less strong than between sid and ohd.

The taskperception of sid, ohd/sid and ohd can be differentiated, as follows form the preceding paragraph. The question can be asked if this perception is an autonomous opinion of the doctors or an expression of the culture of the organization in which they function. Presumably both: their own opinions as well as the culture of the organization, play a role. More than the ohd/sid the sid will be restricted by existing legislation 
and rules in judging the ability to work. Due to his double task the ohd/sid will be less confined to the existing legislation and rules.

Investigation of the factors that influence the duration of sickness absenteeism needs consideration of the taskperception of the doctors charged with the execution of the Sickness Insurance Act.

To include the taskperception of sid and ohd/sid in the investigation of the relation between the duration of sickness absenteeism and doctor- and patient-variables, it will be necessary to construct variables for taskperception. These variables should reflect the taskperception of the doctors engaged in social-insurance practice. In this part of the investigation occupational-health-doctors are included.

With the help of factorial analysis three taskpercaption-variables were composed: company-oriented, person-oriented and group-oriented.

Company-oriented is defined as the degree to which doctors are aiming at reintegration and thereby strongly anticipate on the environment of the patient, the company and the curative sector of the health care. Departing from this company-oriented task-perception the doctor is actively interested in patient and company and tries to take measures that will promote reintegration in the workforce.

Person-oriented is defined as the degree to which doctors are aiming and counselling the patient; for the benefit of this process the coordination with the curative sector is estimated to be important. Due to this person-oriented taskperception the sid or ohd/sid will assume a more controlling position and be less concerned with the work and work-environment of the patient. He pays more attention to the illnes than to the disability to work.

Group-oriented is defined as the degree in which doctors are aiming to work at categories of people. From this group-oriented taskperception the doctors attention is more focussed on prevention of disability, rather than guidance or reintegration. A doctor with this perception of his task is relatively less resultoriented in the sense of resumption of work.

These three taskperceptions have been included as independent variables in the analysis of the difference in the duration of sickness absenteeism. The dicriminating power of these taskperception-variables as to the three categories of doctors has been investigated: it appears that only the variable: company-oriented, distinguishes between sid, ohd/sid and ohd.

\section{The social-insurance medical counselling}

The differences in social-insurance medical counselling (chapter 5) between sid and ohd/sid concern:

1. Counseling activities, both the time of the first appointment as well as the number of appointments. The ohd/sid starts counseling at an earlier point in time and performs more appraisals than the sid. The ohd/sid does more first appraisals 
during the frrst 7 weeks of sickness absenteeism. The odh/sid has at least seen twice all patients whose inability to work has a duration of more than 70 days. On the contrary the sid assesses only once $20 \%$ of the patients with an disability to work of more than 170 days.

2. The forming of an opinion. The ond/sid is rather optimistic about the chance to regain abilitiy to work and actively approaches companies with the intention of taken measures to stirmulate a resumptiom to work. Compared to the ohd/sid the sid has a more pessimistic view of the prognosis concerning the resumption of work.

3. The duration of the the sickness absenteeism. Patients counseled by the ohd/sid are absent of work during a shorter period of time than patients counseled by the sid.

Distance to the employer of the patient appears to be an important factor. The activities of the sid and ohd/sid are primarily aimed at influencing the work and workenvironment. The distance between company and doctor is an important factor. The sid takes care of a small number of companies, while the sid is concerned with a large number of mainly snaller companies. This could be in the order of hundred to a thousand companies per sid. Apart from the difference in the number of companies the sid is also concernd with different types of companies, each with their specific problems. For the sid the contacts with employers are undeniably more difficult as compared to the ahd/sid. Also the companies of the sid-patients are often smaller and have fewer possibilities to take measures promoting an early resumption to work.

\section{The duration of sickness absenteeism}

The total duration of absence can be differentiated in waiting time (this is the time between the moment of reporting ill and the first contact with the sid or ohd/sid) and the counseling period (the time between the first contact between patient and sid or ohd/sid and the end of the counseling). A strong relation exists between waiting time and the duration of disability. For de duration-class shorter than 57 days the waiting time isinfluenced by the regulations of the controlling agency (f.i. the use of lay-controllers); for the duration-class longer than 70 days the seriousness of the disease forms a possible explanation for this relation.

Bij means of multiple regression analysis (mra) the factors cq. variables were investigated, which infuence the duration of sickness absenteeism. It appears that, with only a few exceptions, the factors determining the duration are doctor-related. This is surprising, because usually the non adoctor-related factors, such as type of work, workenvironment, cooperation of the employer as well as insufficient financial incentives for the patient, are considered to be of crucail importance and to have a non-preventable negative influence on absenteeism. The following doctor-related factors have a direct relation with a short duration of sickness absenteeism: 
- a large number of colleagues in the workenvironment of the sid and ohd/sid. Presumably this gives the sid and ohd/sid the opportunity to consult colleagues and compare counseling strategies.

- a high degree of professionalism: regular attendance of post academic courses and the resulting knowledge about illness, therapies and possibilities of reintegration. a taskperception from which the sid and ohd/sid aims at reintegration of the patient and involvement of the employer.

The results of this study confirm the important role of the sid and ohd/sid as a guardian of the entrance to the facilities and benefits of the social security system, especially the Sickness Insurance Act (Ziektewet) and it's extension the Disability Insurance Act (Wet op de Arbeidsongeschiktheidsverzekering).

In diagnostic practices there are no differences between sid and ohd/sid. The differences between their two approaches mainly concern reintegration-activity and cooperation with the employer attended with an higher probability of a long sickness absenteeism for patients counseled by the sid. For the sid the biggest disadvantage is the large number of companies with which he has to deal. This limits the sid in the acquisition and maintenance of specific knowledge about a company or branch of industry an therefor in his reintegration activities in cooperation with the company. Moreover the existing rules of the control-agencies very often lead to the use of lay-controllers, so intervention of the sid or ohd/sid is unnecessarily delayed. Doctor-related factors, like the number of colleagues and the attendance of post academic courses, are significantly correlated with a short duration of sickness absenteeism. As a result of this investigation we can formulate the following recommendations for sid's and control-agencies to reduce tabsence due to illness:

1. Faster interventioning by sid and ohd/sid is required. Apart from a more adequate monitoring of entrance to the Sickness Insurance Act it gives the opportunity of an earlier start of reintegration-activities and results in a shorter duration of sickness absenteeism. In this context it is recommended to investigate to what extent the present legislation offers sufficient opportunities for reintegration.

2. Given the positive contribution to reduction of the sickness absenteeism resulting from concentrating colleagues in one workarea, the working in isolation of sid and ohd/sid should be avoided. Consultation of colleagues and comparision of counseling strategies should be promoted.

3. Both for sid as well as ohd/sid it is imperative to maintain high professional standards: both in general as well as insurance-and occupational medicine by periodic attendance of post-academic tuition.

4. The relation between sid and company urgently needs to be changed. A better knowledge of the different branches of industry and the reintegration possibilities is required to better control and shorten the duration of sickness absenteeism. 


\section{SAMENVATTING}

In 1990 worden het hoge ziekteverzuim en het grote aantal langdurig arbeidsongeschikten beschouwd als een van de belangrijkste politieke en economische problemen in Nederland. Een gemiddeld ziekteverzuimpercentage van $8,5 \%$ en een aantal langdurig arbeidsongeschikten, dat de 900.000 nadert, maken de omvang van het probleem duidelijk. Of werknemers arbeidsongeschikt worden beschouwd wordt bepaald door de bedrijfswerenigingen, die belast zijn met de uitwoering van onder andere de ziektewet (ZW) en de wet op de arbeidsongeschiktheidsverzekering (WAO). Zij baseren zich hierbij op adviezen van artsen: verzekeringsgeneeskundigen (vg'n) en bedrijfsarts/verzekeringsgeneeskundigen (ba/vg'n) Deze studie geeft de resultaten weer van het onderzoek naar het handelen van vg'n en ba/vg'n en de relatie tussen hun handelen en de arbeidsongeschiktheidsduur.

In hoofdstuk 1 is de aanleiding voor deze studie beschreven. Het belangrijkste vertrekpunt vormt het streven van de overheid naar een reductie van het ziekteverzuim en het terugdringen van het grote aantal langdurig arbeidsongeschikten. Sedert het midden van de jaren vijftig is uitgebreid onderzoek gedaan naar de oorzaken van ziekteverzuim. Desalniettemin is de rol van de verzekeringsgeneeskundige of met verzekeringsgeneeskundige taken belaste artsen nooit expliciet onderzocht.

In Nederland zijn twee categorieën artsen belast met de uitvoering van de ziektewet en soortgelijke regelingen voor ambtenaren:

1. verzekeringsgeneeskundigen van de bedrijfsvereniging, die de advisering en begeleiding in het kader van de ziektewet uitvoeren, de vg'n, en

2. de bedrijfsartsen, die - in dienst van een bedrijf, instelling of bedrijfsgezondheids" dienst - maast hun bedrijfsgeneeskundige ook een verzekeringsgeneeskundige taak hebben: de ba/vg'n.

Deze studie is geënt op de Nederlandse situatie. De verschillen in sociaal verzekeringsstelsel tussen de verschillende Europese landen is zo groot, dat een vergelijking vrijwel onmogelijk is.

De plaats van de verzekeringsgeneeskundige in Nederland kenmerkt zich door:

1. een scheiding tussen behandeling en controle, en

2. een scheiding tussen bedriffsgezondheidszorg en verzekeringsgeneeskunde.

Dit betekent, dat vergelijkingen tussen de taakuitwoering van artsen in de verschillende landen vrijwel onmogelijk is. De internationale literatuur op dit terrein is dan ook slechts beperkt bruikbaar.

De probleemstelling, zoals weergegeven in hoofdstuk 2 , is uitgewerkt in een viertal vragen:

1. Welke activiteiten ontplooien verzekeringsgeneeskundigen en bedrijfsarts/verzekeringsgeneeskundigen in het kader van de controle en begeleiding? 
2. Zijn er verschilien in activiteiten en takopvatting tussen deze twee groepen artsen?

3a. Zijn de verschillen in arbeidsongeschiktheidsdur afhankelik wan de takopvatuingen en activiteiten van de verzekeringsgeneeskundige en bedrijfsarts/verzekeningsgeneeskundige?

3b. Zijn de werschillen in ao-duur afhankelijk van de organisatorische context, waarbinnen de vg en ba/vg werktaam zijn?

De opzet en wifvoering wan het onderzoek is beschreven in hoofdstuk 3. Het handellen van $35 \mathrm{vg} n$ en ba/ $\mathrm{vg}$ ' $\mathrm{n}$ is gevolgd alan de hand van de begeleiding van 482 patienten vanaf de tweede t/m de negende arbeidsongeschiktheidsmaand.

\section{De taakopvattingen}

Het onderzoek naar taakopwattingen (Hoofdstuk 4) beperkt zich niet uitsluitend tot de $35 \mathrm{vg}$ 'n en ba/vg"n, maar is ook gehouden onder 16 bedrijfsartsen. Met behulp van een 14-tal taakopvattingen-clusters zijn de drie categorieen artsen te onderscheiden.

De verzekeringsgeneeskundige is vooral op de sturing van de patiënt gericht. Hierbij staat de formele tak en de wetsuitvoering voorop. De vg hecht geringe waarde aan het bestaan van een vertrouwensrelatie en richt zich vanuit een ruime opvatting ten aanzien van de taakomvang op de omgeving van de patiënt. Bij de reïntegratie heeft de $v g$ in mindere mate behoefte aan informatie vanuit het bedrijf. De $\mathrm{vg}$ kan op basis van zijn opvattingen als een sturings(taak)gerichte arts worden beschouwd.

De bedrijfsarts/verzekeringsgeneeskundige is vooral op de omgeving gericht; hieronder worden zowel groepen patiënten als het bedrijf verstaan. Vanuit deze omgevingsgerichtheid is thij geinteresseerd in de preventie. Vanuit deze taakopvatting hecht hij veel waarde aan de relatie met patiënten, het bedrijf en de curatieve sector. De ba/vg kan gekarakteriseerd worden als relatiegericht.

De bedrijfsarts richt zich wootal op het bedrijf en is erg op resultaat gericht. De ba acht de middelen om zijn doel te bereiken te beperkt. Zijn invalshoek is de preventie. Zijn opvatting over de takomvang is beperkter dan die wan de vg en ba/vg. De ba identificeert zich meer met de bedrijlsgezondheidszorg dan met de verzekeringsgeneeskunde. De ba kan op basis van de takkopvattingen gekarakteriseerd worden als bedriffsgericht.

Op basis van de taakopvattingen is het onderscheid tussen $v g$ en ba het sterkst. Niet verwonderlijk gellet op de sterk uiteenlopende taken van deze twee categorieèn artsen. De ba immers heeft uitsluitend een bedrijfsgeneeskundige taak; de vg een uitsluitend verzekeringsgeneeskundige taak. De ba/vg evenwel heeft zowel een bedrijfsgeneeskundige als verzekeringsgeneeskundige taak; het onderscheid in takkopvattingen tussen ba/vg en vg alsook tussen ba/vg en ba is dan ook minder sterk. 
De takopvattingen van $\mathrm{vg}$, ba/vg en ba zijn te onderscheiden. De vraag rijst of wij hier te maken hebben met autonome opvattingen van artsen of opvattingen, die geent zijn op de culnur van de organisatie, waarbinnen deze artsen werkzaam zijn. Baide spelen vermoedelijk een rol. De vg zal meer dan de ba/vg gebonden zijn aan wetgeving en regelgeving.

Onderzoek naar factoren, die van invloed zijn de arbeidsongeschiktheidsdur, is on volledig als de taakopvattingen van de met de wirvoering belaste artsen buiten beschouwing blijven. Om de taakopwattingen van verzekeringsgeneeskundige en bedrifisarts/verzekeringsgeneeskundige in het hierna te bespreken onderzoek naar de sannenhang ussen arbeidsongeschiktheidsdunr en arts- en patiëntwariabelen mee te kunnen nemen, zijn met behulp van de factoranalyse een drietal taakpvattingsvariabelen samengesteld: bedrijfsgericht, individugericht en groepsgericht.

Onder bedrifsgericht wordt verstaan de mate waarin artsen zich sterk richten op de reïntegratie en daarbij sterk anticiperen op de omgeving van de patiënt, het bedrijf en de curatieve sector.

Vanuit deze bedrijfsgerichte taakopvatting stelt de arts zich actief op naar patiënt en bedrijf en tracht dié maatregelen te nemen, die een reüntegratie in werk bevorderen.

Onder individugericht wordt verstaan de mate waarin artsen zich sterk richten op de begeleiding van de individuele patient; ten behoeve van deze begeleiding wordt de coördinatie met de curatieve sector van belang geacht. Vanuit deze individugenichte taakopvatting zal de $\mathrm{vg}$ of ba/vg zich meer controlerend opstellen en zich minder inlaten met het werk en de werkomgeving van de patiënt. Hij richt zijn aandacht meer op de ziekte dan op de arbeidsongeschiktheid.

Onder groepsgericht worden verstaan de mate waarin artsen zich sterk op de groepsbenadering richten. Vanuit deze groepsgerichte taakopvatting zal de arts zich relatief meer met de preventie dan met de begeleiding of reintegratie bezighouden. Een arts met deze taakopvatting is relatief minder op resultaat in de zin van werkhervatting gericht.

Deze drie taakopvattingen zijn als onafhankelijke variabelen meegenomen bij de verklaring van de verschillen in arbeidsongeschiktheidsduur (ao-duur). Uiteraard is onderzocht in hoeverre deze taakopvattingsvariabelen een onderscheidend vermogen hebben naar de categorie arts. Alleen de taakopvattingsvariabele bedrifsgericht maakt een significant onderscheid tussen de drie categorieèn artsen.

\section{De verzekeringsgeneeskundige begeleiding}

De verschillen in verzekeringsgeneeskundige begeleiding (hoofdstuk 5) tussen de vg en ba/vg betreffen:

1. De begeleidingsactiviteiten. Er bestaan verschillen met betrekking tot het moment van de eerste verzekeringsgeneeskundige beoordeling als het aantal beoordelingen. De ba/kg start zijn activiteiten eerder, met name in de eerste 7 arbeidsongeschiktheidsweken, en verticht meer vervolgbeoordelingen. De ba/vg heeft alle patienten 
met cen arbeidsongeschiktheidsduur van meer dan 70 dagen minimaal tweemaal op het spreekuur gezien. De vg daarentegen heeft $20 \%$ van de patiënten met een arbeidsongeschiktheidsduur van meer dan 170 dagen slechts éénmaal op het spreekuur gezien.

2. De oordeelsvorming. De ba/vg is in vergelijking met de vg relatief optimistisch ten aanzien van de werkhervattingskansen en zoekt meer dan de vg contact met bedrijven voor het treffen van maatregelen, die een werkhervatting kunnen bevorderen.

3. De arbeidsongeschiktheidsduur. De door de ba/vg begeleide patiënten verzuimen korter dan de door de $\mathrm{vg}$ begeleide patiënten.

De afstand tussen arts en bedrijf lijkt een belangrijke factor. Wat dat betreft bestaan er grote verschillen tussen $\mathrm{vg}$ en ba/vg. Waar de $\mathrm{vg}$ te maken heeft met een zeer groot aantal en vooral kleinere bedrijven uit zeer verschillende bedrijfstakken, heeft de ba/vg in de regel de zorg voor werknemers van een beperkt aantal en wat het aantal werknemers betreft grotere bedrijven.

Ook zijn de mogelijkheden tot werkaanpassingen of andere de werkhervatting bevorderende maatregelen in kleinere bedrijven in de regel geringer. De $\mathrm{vg}$ beschikt om deze redenen over minder mogelijkheden dan de ba/vg.

\section{De arbeidsongeschiktheidsduur}

De arbeidsongeschiktheidsduur kan worden onderscheiden in de wachttijd: de periode tussen het moment van ziekmelden en heet eerste contact tussen patiënt en $\mathrm{vg}$ of ba/vg, en de begeleidingsperiode: de periode tussen het eerste contact patiënt - vg of ba/vg en het beëindigen van de begeleiding. Er bestaat een sterke samenhang tussen de wachttijd en de arbeidsongeschiktheidsduur. Voor de duurklasse $\leq 57$ dagen wordt deze vermoedelijk bepaald door de regelgeving van de uitvoeringsorganisatie (bijvoorbeeld de inschakeling van lekencontroleurs); voor de duurklasse $>70$ dagen is de ernst van de ziekte en thet in verband hiermee vaker moeten consulteren van een specialist een mogelijke verklaring voor deze samenluang.

Met behulp van de multiple regressie-analyse is onderzocht welke factoren een samenhang hebben met een relatief korte of lange arbeidsongeschiktheidsduur. Er bestaat een samenhang tussen een relatief korte arbeidsongeschiktheidsduur en een hoge mate van professionaliteit van de $\mathrm{vg}$ of ba/vg, het kunnen onderhouden van contacten met collega-artsen en vooral het werken vanuit een bedrijfsgerichte taakopvatting.

De uitkomsten van dit onderzoek bevestigen de belangrijke rol die de $\mathrm{vg}$ en ba/vg vervullen als toegangsbewakers tot de sociale verzekeringen: ziektewet en in het verlengde hiervan de wao, en vergelijkbare regelingen voor ambtenaren.

De verschillen tekenen zich af in de werkwijzen: de reïntegratie-activiteiten en de samenwerking met het bedrijf. De door de $\mathrm{vg}$ begeleide patiënten hebben een grotere kans op langerdurende arbeidsongeschiktheid. 
Op grond van dit onderzoek kunnen de volgende aanbevelingen geformuleerd worden:

1. een snellere interventie door $\mathrm{vg}$ en ba/vg is noodzakelijk, niet alleen als toegangsbewaking maar vooral om de begeleiding zo snel mogelijk te kunnen starten hetgeen resulteert in een kortere arbeidsongeschiktheidsdwur. Het verdient aanbeveling na te gaan in hoeverre de thans vigerende wetgeving voldoende mogelijkheden biedt tot het ontplooien en ondersteunen van reïntegratie-activiteiten.

2. Gegeven de positieve bijdrage aan de verkorting van de arbeidsongeschiktheidsduur, die uitgaat van het werken met meerdere collega-artsen op de werkplek van de $v g$ en ba/vg dienen soloposten zoveel mogelijk vermeden te worden.

3. Zowel voor de vg als ba/vg is het op peil houden van de vakinhoudelijke d.w.z. de algemeen medische en verzekeringsgeneeskundige alsook arbeidskundige kennis door het volgen van bij- en nascholing onmisbaar. Aangezien de beroepsgroep bijen nascholing (nog) niet verplicht stelt, zullen de uitvoeringsorganisaties zorg moeten dragen voor een regelmatige bij $\propto$ en nascholing.

4. De relatie tussen bedrijf en $\mathrm{vg}$ of ba/vg is van grote invloed op de arbeidsongeschiktheidsduur van de verzorgde populatie. Een grote kennis van de verschillende bedrijfstakken en branches zal leiden tot een kortere arbeidsongeschiktheidsduur door een betere toegangsbewaking en meer mogelijkheden tot het treffen van reïntegratie-bevorderende maatregelen.

5. Bij de reïntegratie zijn patiënt, arts en werkgever betrokken. Het verdient aanbeveling om in het verzekeringsstelsel op reïntegratie gerichte financiële prikkels op te nemen voor zowel patient als werkgever. 



\section{LITERATUUR}

Algemeen Burgerlijk Pensioenfonds (ABP), Beleidsinformatiegids Arbeidsongeschiktheidsregelingen Ambtenaren. ABP, Heerlen, 1985.

Algemeen Rijksmabtenaren Reglement (ARAR), Ambtenarenwet 1929. Tjeenk Willink, Zwolle, 1985.

Bax, E.H., De stijging van de arbeidsongeschiktheid in de jaren zeventig. Beleid en analyse. Mens en Maatschappij, 1982 (57) 117-144.

Behrend, $\mathbb{H}$., Absence and Labour turnover in a changing economic dimate. Occupational Psychology, 1953 (27) 69-79.

Bergink, A.H., Samuel Senior Coronel. Van Gorcum \& comp. N.V., Assen, 1960.

Bijlsma, T, en Koopmans, F., Bedrijfsverenigingen en arbeidsongeschiktheid. Tijdschrift voor Sociale Geneeskunde 1984 (62) 535-544.

Bohm, W.Th., Begeleiding ziekteverzuim door de bedrijfsarts. Medisch Contact, 1981 (36) $186-188$.

Bommel, G. van, Vergelijking van het ziekteverzuim van Belgische en Nederlandse werknemers. Scriptie SSG. Stichting Sociale Gezondheidszorg, Utrecht, 1986.

Boorder, Tj. de, Zou Coronel nu tevreden zijn? Tijdschrift voor Sociale Geneeskunde, 1983 (61) $487-491$.

Boots, J.M.J., Het werk van de huisarts. Dissertatie. Rijksuniversiteit Limburg, Maastricht, 1983.

Boots, J. en W. van Zutphen, Taakopvattingen van de huisarts. Medisch Contact, 1981 (36) $65-68$.

Broeder, A.L. den, Taak en toekomst van de verzekeringsgeneeskunde; Tijdschrift voor Verzekeringsgeneeskunde, 1985 (23) 6-7.

Broeder, A.L. den, Herziening van de organisatie van de sociale zekerheid. Sociaal Maandblad Arbeid, 1988 (43) 352-362.

Bruin, P. de, Invloed van ziektewetuitvoering op het ziekteverzuim. Cahier 85-05. GAK, Amsterdam, 1985. 
Buhring, E., Ziekteverzuim en conjunctuur in de lextelindustrie. I. Tijdschrift voor Sociale Geneeskunde, 1977 a (55) $186-189$.

Buhring, $\mathbb{E}$, Zlekteverzuim en conjunctuur in de textielindustrie II. Tijdschrift voor Sociala Geneeskunde, $1977 \mathrm{~b}$ (55) $225-228$.

Buis, H.A.M., De ontwikkeling van het begrip "ziekte of gebrek" in de literatuur en jurisprudentie. Tijdschrift voor Verzekeringsgeneeskunde, 1986 (24) 134-135 en 150.

Butger, G.C.E., Gerritsen, W.B., De Groot, J., Kuiper, J.P. en Zielhuis, R.L., Arbeidsen Bedrijfsgeneeskunde. Sterfert Kroese, Leiden, 1974.

Buys, P.C., Curatieve gezondheidszorg, ziekteverzuim en arbeidsongeschiktheid. CCOZ, Ansterdam, 1985.

Buys, P.C., Sociaal-medische begeleiding. Medisch Contact, 1988 (38) 1131-1136.

Commission of the European Communities, Comparative tables of the Social Scurity schemes, 14 th edition. EC, Brussel, 1988.

Commissie Samenwerking Verzekerings- en Bedrijfsgeneeskunde, Naar cen verbeterde samenwerking. Tijdschrift voor Verzekeringsgeneeskunde, 1988 (26) 60-63.

Crousen, A.M.F.B., Analyse van het werk van een controlerend geneeskundige voor de ziektewet. Dissertatie. Katholieke Universiteit Nijmegen, Mijmegen, 1968.

Crowther, In, Absence and turnover in the division of one company, 1950-1955. Joumal of Occupational Psychology, 1957 (31) 256-265.

Doeleman, F., De plats van de sociale geneeskunde in de gezondheidszorg. In Tordoir (red.) $1980,1-26$.

Draaisma, D. en P.G.W. Smulders, Ziekteverzuim en het bedrijf. NIPG/TNO, Leiden, 1978.

Duming, A.J., Het medisch handelen als proces. Medisch Contact, 1984 (39) $269-271$.

Dijk, J.F.J. van, Haselen, D.A. van, Lenshoek, D.E., Hellinga, P., Boer, S. de, en Koffeman, C., WAO-toetreding: trends en risicogroepen in een groot industrieel bedrijl. Tijdschrift voor Sociale Geneeskunde, 1987 (65) 654-662.

Dijkstra, A. en W.F. Tordoir, Samenwerking tussen bedrijfsarts en huisarts. Medisch Contact., 1974 (29) 680-684.

Eck, M.A.A. van, Het beslissingsproces van de medische functie van het GAK. Dissertatie. Universiteit van Amsterdam, Amsterdam, 1990. 
Emanuel, H., Moet de Gemeenschappelijk Medische Dienst opgeheven worden? Sociaal Maandblad Arbeid, 1988 (43) 375-388.

Engers, R.W. van, M.A.J. van Groenestijn en W.T van der Knaap, Ziekteverzuim van vrouwen en mannen; de invloed van persoons- en werkfactoren op verzuim in cen groot administratief bedrijf. GAK, Amsterdam, 1987.

Epker, W., Vg en curatieve sector. GAK, Amsterdam 1986.

Financiële Nota Sociale Zekerheid 1990. Ministerie wan Sociale Zaken en Werkgelegenheid, "s-Gravenhage, 1990.

Galan, C. de en H. Windmuller, Arbeidswerhoudingen in Nederland. Spectrum, Utrecht, 1974.

Geers, A.J.C.M., Recht en humanisering van de arbeid. Dissertatie. Rijksuniversiteit Limburg, Maastricht, 1988.

Gemeenschappelijk Administratiekantoor (GAK), Informatiesysteem Medische Dienst. GAK, Amsterdam, 1985.

Gemeenschappelijk Administratiekantoor (GAK), Informatiesysteem Medische Dienst; Amsterdam, 1987.

Gemeenschappelijk Administratiekantoor (GAK), ZWB 1989.

Gemeenschappelijk Administratiekantoor (GAK), Verzekeringsgeneeskundigen over hun werk: Taakopvattingen en contacten met de curatieve en bedrijfsgeneeskundige sector. GAK, Amsterdam, 1986.

Gemeenschappelijk Medische Dienst (GMD), Statische Informatie 1985. GMD, Amsterdam, 1986.

Gemeenschappelijk Medische Dienst (GMD), Jaarverslag 1986. GMD, Amsterdam, 1987.

Gemeenschappelijk Medische Dienst (GMD): Statistische informatie 1989. GMD, Amsterdam, 1990.

Gerritsma, J.C.M. en J.A. Smal, Besliskunde, een nieuwe loot aan de boom van het medisch onderwijs. Medisch Contact, 1984 (39) 179-182.

Gill, K., Protocollaire geneeskunde, Keurslijf of aanwinst voor de huisarts? Medisch Contact, 1983 (38) 1057-1059.

Graaf, A. de, Saciaal-medische begeleiding van arbeidsongeschikte werknemers. Tijdschrift voor Verzekeringsgeneeskunde, 1987 (25) 70-75. 
Graaf, L. de, Verzuimbestrijding en hunanisering van de arbeid. Tijdschrift voor Sociale Geneeskunde, 1980 (58) 490-493.

Graaf, L. de, Het belang van deeiname aan arbeid door gehandicapte mensen. Tijdschrift woor Verzekeringsgeneeskunde, 1987 (25) $162-163$.

Grond, J.Th.H., De scheiding van behandeling en controle. Tijdschrift voor Sociale Geneeskunde, 1980 (58) 669-678.

Grond, J.Th.H. en D. de Pater, Arts en arbeidsongeschiktheid. Medisch Contact, 1980 (37) $1131-1136$.

Groot, J.W. de, Verhandelingen XXXIII: Kwantitatieve benadering van het verzuim door neurosen bij Nederlandse fabrieksarbeiders. NIPG, Leiden, 1958.

Groothoff, J.W., Gezondheidszorg en 3e-maandsverzuimgevallen. Tijdschrift voor Sociale Geneeskunde, 1981 (59) 42-49.

Heuperman, H.J.J., Sociale verzekeringsgeneeskunde als wetenschap. Tijdschrift voor Verzekeringsgeneeskunde, 1986 (24) 191-192.

Heuvel, van de F.G., W.A. Sinnighe Damsté en T.K. Westerduin, Aan de slag; de toekomst van arbeidsongeschikten en werklozen. Stichting Maatschappij en Onderneming, "s-Gravenhage, 1990.

Hoof, J.A.P. van en P. Nas, Enkele karakteristieken van het ziekteverzuim in een aantal bedrijven uit Maastricht en omgeving. Katholieke Universiteit Nijmegen, Nijmegen, 1967.

Horst, F.G.E.M. van der, Gezondheid en niet werken. Dissertatie. Rijksuniversiteit Limburg, Maastricht, 1988.

Hullenaar, R.H.J, van, en Koningsveld, D.B.J. van, Afgebrand of afgedankt; een onderzoek naar oorzaken van arbeidsongeschiktheid. Sets en Zeitlinger, Lisse, 1986.

International Committee of Medical Journal Editors, Uniform requirements for manuscripts submitted to biomedical journals. British Medical Journal, 1982 (284) 17661770.

International Classification of Diseases, 9th revision, 1975.

Jong, E.P. de en W.M. Levelt-Overmans, L'histoire se répète: verband tussen uitvoering en stelsel van sociale verzekeringen. Sociaal Maandblad Arbeid, 1988 (43) 363-374.

Kagenaar, D.B., Omzien en vooruitzien, een afscheid. Tijdschrift voor Verzekeringsgeneeskunde, 1985 (23) 81 . 
Kastelein, A. en H.H.M. Willens, Diagnostische werrichtingen en algorithmen. Medisch Contact, 1980 (35) 304-306.

Kesteloo, A., Bedrijfsgeneeskundige aspecten van een dreigende bedrijfssluiting. Dissertatie. Katholieke Universiteit Nijmegen, Nijmegen, 1974.

Keuring, D. en D.J. Eppink, Management en organisatie. Stenfert Kroese, Leiden/Antwerpen, 1987.

Klerk, J.M. de, G.C. Diependaal en C.J. Petersen, Psychische stoornissen en arbeidsongeschiktheid. Tijdschrift voor Verzekeringsgeneeskunde, 1986 (24) 136-142.

Kruidenier, H.J., Ziekteverzuim en conjunctuur. Stichting CCOZ, Amsterdam, 1981.

Lammers, C.J., Uiterlijke samenhang en bindingskracht van de organisatie. Van Gorcum, Assen, 1964.

Lancée, W.H.J., Psychologisch onderzoek inzake arbeidsongeschiktheid. Dissertatie. Rijksuniversiteit Limburg, Maastricht, 1988.

Landelijke Huisartsenvereniging, Landelijke Vereniging voor Sociale Geneeskunde, model voor sociaal medische begeleiding. Medisch Contact, 1986 (41) 88-90.

Mansvelt, J. van, R.C. Brunsting, B.M.J. Delamarre en H.A. van der Wall, Een onderzoek naar oorzakelijke factoren en bijzondere kenmerken bij het langerdurend arbeidsverzuim. Medisch Contact, 1975 (30) 79-84.

Mayo, E., The social problems of an industrial civilization. Harvard, Boston, 1945.

Meems, A., Een onderzoek naar de effecten van een dreigende bedrijfssluiting ( 7 recidivi en 70 primi). Tijdschrift voor Sociale Geneeskunde, 1981 (59) 565-571.

Merens-Riedstra, H.S, en W.J. van Ende, Verslag van een onderzoek naar samenwerking tussen artsen. Medisch Contact, 1973 (28) 717-721.

Merens-Riedstra, H.S., Leven zonder werk; een sociaalwetenschappelijk onderzoek naar arbeidsongeschiktheid. Dissertatie. Rijksuniversiteit Limburg, Maastricht, 1981.

Mertens, A.Th.L.M. en J.C. Streng, Eindverslag werkzaamheden commissie "Bestrijding Ontwikkeling Ziekteverzuim". SVR, Zoetermeer, 1981.

Ministerie van Sociale Zaken en Werkgelegenheid, Adviesaanvrage sociaal-medische begeleiding aan de Nationale Raad voor de Volksgezondheid bij ziekte en arbeidsongeschiktheidsregelingen. Z.pl. 1983. (Kenmerk SZ/BO no. 52.548: juli 1983). Ministerie van SoZaWe, 's-Gravenhage, 1983. 
Molendijk, A.D., Verzum en invalidisering bij Rotterdamse gemeente-ambtenaren in 1979. Trjdschrift voor Sociale Geneesunde, 1980 (58) supplement 68-70.

Nederlandse Vereniging voor Arbeids- en Bedrijfsgeneeskunde (NWAB), Bedrifsgezondheidszorg in perspuectief. NVAB, Budel, 1988.

Nederlandse Vereniging voor Verzekeringsgeneeskunde (NVVG), Advies sociaal-medische functle social verzekeringsgeneskundige: rapport van de commissie sociaal-medische functie van de NVVG inzake het samenwerkingsverband tussen medische diensten van $B V^{5} n$ en $G M D$, alsmede organisatorische consequenties. Tijdschrift woor Verzekeringsgeneeskunde, 1987 (25) supplement nr. 1.

Nelson, E.C., A.R. Jacobs en P.E. Breer, A study of the validity of the Task Inventory Method of Job-analysis. Medical Care, 1975 Vol. XIII nr. 2 104-113.

NIPG/TNO, Ziekteverzuim, WAO-intrede en verzekeringsvorm in de Ziektewet; een onderzoek onder 119 bedrijven naar achtergronden van verschillen in arbeidsongeschiktheid buj Afdelingskassen, Eigen-risicodragers en Omslagleden. NIPG/TNO, Leiden, 1983.

NIPG/TNO, Het ziekteverzuim in 1989. NIPG/TNO, Leiden, 1990.

Nijhuis, F.J.N., Beoordelingen van organisatiekenmerken; Dissertatie. Rijksuniversiteit Limburg, Maastricht, $1984 \mathrm{a}$.

Nijhuis, F.J.N., Economische achteruitgang in bedrijven en ziekteverzuim. Mens \& Onderneming, Tijdschrift voor Organisatiekunde en sociaal beleid, $1984 b$ (38) $400-412$.

Nijhuis, F.J.N. en J.M.L.M. Soeters, Werk en Ziekte. Rijksuniversiteit Limburg, Maastricht, 1982.

Pater, D. de, Verzekeringsgeneeskundige aspecten. Medisch Contact, 1982 (37) 13471348.

Philipsen, H. Enkele aspecten van het stijgend ziekteverzuim. 2. De beslissing om ziek te worden en veranderde opvattingen over de verzuimnoodzaak. Mens en Ondememing, $1966(20) 280-291$.

Philipsen, H., Afwezigheid wegens ziekte. Wolters-Nordhoff, Groningen, 1969.

Philipsen, H., Levensfase, generatie en ziekteverzuim. Rijksuniversiteit Limburg/Nederlands Instituut woor Praeventieve Geneeskunde TNO, Maastricht/Leiden, 1977.

Plomp, H.N., Werknemers en bedrijfsgezondheidsdiensten. Vrije Universiteit Amsterdam, Amsterdam, 1985. 
Plomp, H.N., Bedrijven en bedriffsgezondheidsdienster. Vrije Universiteit Amsterdam, Amsterdam, 1987.

Plummer, N. en L.E. Hinkle, Sickness Absenteeism. Archives of Industriall Health, 1955 (11) $218-230$.

Poelstra, P.A.M., J. Dronkers en A.M. Jacobi, Verschillen in ziektewetcontrole tussen bedrijfsverenigingen. Federatie van Bedrijfsverenigingen (FBV), Amsterdam, 1985.

Poelstra, A.M., De fictie van de omvang van het grijze verzuim. "Tijisschrift voor Verzekeringsgeneeskunde, 1987 (25) 105-107.

Polak, B.S., Het begrip ziekte in de zin der ziektewet. Medisch Contact, 1979 (34) 1018. 1020 .

Polak, B.S., Nagekomen reactie op de verzekeringsgeneeskundige studiedagen 1981. Tijdschrift voor Sociale Geneeskunde, 1982 (60) 148.

Polak, B.S., Samenvatting van studiedagen sociale verzekeringsgeneeskunde 1983; Tijdschrift voor Sociale Geneeskunde, 1983 (61) 678-681.

Polak, B.S., De begeleiding en conflict-voorkomende rol van de huisarts bij de uitvoering van de sociale verzekeringsgwetten (Ziektewet, AAW/WAO); Nederlands Tijdschrift voor Geneeskunde, 1984 (128) 408-412.

Prins, R., Sickness Absence in Belgium, Germanu (FR) and the Netherlands, a comparative study. Dissertatie. Rijksuniversiteit Limburg, Maastricht, 1990.

Rijks Geneeskundige Dienst (RGD), Structuurnota Rijks Geneeskundige Dienst "82". RGD, "s-Gravenhage, 1982.

Sluijs, E.M., J.P. Dopheide en J, wan der Zee, Overzichtsstudie Onderzoek Eerstelijn; Stand van het wetenschappelijk onderzoek in en over de eerstelijnsgezondheidszorg en haar raakvlakken. Nederlands Instituut voor onderzoek van de eerstelijnsgezondheidszorg (NIVEL), Utrecht, 1985.

Smulders, P.G.W., Bedrijfskenmerken en ziekteverzuim in de jaren zestig en tachtig. Dissertatie. Rijksuniversiteit Limburg, Maastricht, 1984 a.

Smulders, P.G.W. Balans wan 30 jaar ziekteverzuimonderzoek. NIPG-TNO, Leiden, $1984 \mathrm{~b}$.

Smulders, P.W.G. en Veerman, Handboek Ziekteverzuim; güds voor de bedrijfspraktijk. DELWEL, 's-Gravenhage, 1991. 
Social Economische Rad (SER): Onwerpadvies over de herziening wan de uitwoering wan de sociale verzekering. R no. 1872. SER, Zoetermeer, 1990.

Sociale Verzekeringsrad (SVR), Statistiek, Ontwikkeling arbeidsongeschiktheid 19851986. SVR, Zodtermeer, 1988 .

Soeters. I., Afwezightid wegens ziekte in het herstructureringsgebied Zuid-Limburg. Rijksuniversiteit Limburg, Mastricht, 1980.

Soeters, J.M.L.M., Patient, gezondheidszorg en langdurige ziekte. Dissertatie. Rijksuniversiteit Limburg, Maastricht, 1983.

Speller, I.M.J.L. en E.J. Hulscher-Hijszeler, Het kontakt-vg-schap als methode van bedrijfsgericht werken. Tijdschrift voor Verzekeringsgeneeskunde, 1986 (24) 103-105.

Steenberge, J. van, Het arbeidsongeschiktheidsbegrip in evolutie. Tijdschrift voor Verzekeringsgeneeskunde, 1986 (24) 212-219.

Steers, R.M. and S.R. Rhodes, Major influences and employee attendance; a process model. Journal of Applied Psychology, 1978 (63) 391-407.

Streng, J.C., Het handelen van artsen bij ziekteverzuim; Tijdschrift voor Sociale Geneeskunde, 1983 (19) 646-651.

Streng, J.C., Sterke en zwakke kanten van de beroepsrevalidatie in Nederland. Tijdschrift voor Verzekeringsgeneeskunde, 1987 (25) 193-195.

Swaan, A. de, Zorg en de staat. Bakker, Amsterdam, 1989.

Taylor, P.J. and Pocock, S.J.: Postwar trends in sickness absence and unemployment in Great Britain. Lancet, 1969 nr. 2 1120-1123.

Timmer, M., Verzekeringsgeneeskundig referentiekader, aanzet tot een verdere professieontwikkeling. Tijdschrift voor Verzekeringsgeneeskunde, 1985 a (23) 22-24.

Timmer, M.: Verzekeringsgensskundig referentiekader. Stoornissen in de verzekeringsgeneeskundige zin. Tijoschrift voor Verzekeringsgeneeskunde, $1985 \mathrm{~b}$ (23) $40-42$.

Timmer, M., Sociale verzekeringsgeneeskunde als wetenschap. Universiteit van Amsterdam, Amsterdam, 1986.

Tordoir, W.F., M.M. van der Klaauw EN C.M.J. van Maanen-Boekestein, Gezondheidszorg en lange ziekteduren. NIPG/TNO, Leiden, 1978.

Tordoir, W.F., Sociale geneeskunde in de praktijk. Bohn, Scheltema \& Holkema, Utracht, 1980. 
Verbaan, D. Sociale ongelijkheid en ziekteverzuim; Tijdschrift voor Sociale Geneeskunde, 1980 (58) supplement 77-79.

Verbond van Nederlandse Ondernemingen, Najaarsoverleg 1990; tripartite akkoord inzake arbeidsongeschiktheid. Onderneming, 1990.

Verhaak, P.F.M., Interdoktervariantie bij psychosociale problematiek: eerste interimrapport. Nederlands Huisartsen Instituut, Utrecht, 1983.

Verhaak, P.F.M., Interdoktervariantie bij psychosociale problematiek: tweede interimrapport. Nederlands Huisartsen Instituut, Utrecht, 1984a.

Verhaak, P.F.M., Het waarnemen van psychosociale probiematiek: waarom ziet de ene huisarts wat de andere niet ziet? Gezondheid en Samenleving, 1984b (5) 242-251.

Vissers, T.C.G.M., Protocollaire geneeskunde. Medisch Contact, 1983 (38) 685-688.

Vroege, D., Ziekteverzuim in Nederland, een bedrijfsgeneeskundige visie. Bedrijfsgezondheidsdienst Rotterdam. Rotterdam, 1982.

Vroege, D., Ziekteverzuim, arbeidsongeschiktheid en sterfte in relatie tot het Nederlandse arbeidsproces. Tijdschrift voor Sociale Gezondheidszorg, 1983 (61) 920-927.

Winter, C.R. de en A. Dijkstra, De bedrijfsarts over zijn werk. NIPG-TNO, Leiden, 1984.

Zwam, H.J. van, Fabriek of werkplaats: arbeidswet 1919, veiligheidswet 1934, arbeidsomstandighedenwet; Sociaal Maandblad Arbeid, 1988 (43) 389-394. 



\title{
Bijlage 1. Overzicht sociale verzekeringswetten in Nederland in 1989 en de uitvoeringsorganisaties
}

\author{
Sociale Verzekeringswetten:
}

Zlektewet (1930) ZW

verzekering van werknemers tegen de geldelijke gevolgen van kortdurende (maximaal 52 weken) arbeidsongeschiktheid wegens ziekte of gebrek.

Ziekenfondswet (besluit 1941; wet 1966$)$ ZFW

verzekering wan werknemers en hun gezinsleden tegen de kosten van genees" en heelkundige behandeling.

Algemene Ouderdomswet (1957) AOW

verzekering van werkmemers en hun gezinsleden tegen de kosten van genees- en heelkundige behandeling.

verzekering van ingezetenen tegen de geldelijke gevolgen van ou derdom.

Algemene Weduwen- en Wezenwet (1959) AWW

Algemene Kinderbijslagwet (1941, 1963) AKW

Wet op de Arbeidsongeschiktheidsverzekering (1967) WAO

Algemene Wet Bijzondere Ziektekosten (1968) AWBZ

Wet Arbeidsongeschiktheidsvoorziening Militairen (1972)

WAMIL

Algemene Arbeidsongeschiktheidswet (1976) AAW

Nieuwe Werkloosheidswet (1987) (N)WW

werzekering van ingezetenen tegen de geldelijke gevolgen wan overlijden van echtgenoot $(\mathrm{m} / \mathrm{v})$ of ouders.

verzekering van ingezetenen tegen onderhoudskosten van kinderen.

verzekering wan werknemers tegen de geldelijke gevolgen van langdurige arbeidsongeschiktheid.

verzekering wan ingezetenen tegen kosten van behsudeling van langdurige ziekten of ermstige gebreken.

Uitkering aan dienstplichtige militairen na het verlaten wan de dienst op voet van de $Z W$ en de WAO.

verzekering van ingezetenen tegen de geldelijke gevolgen van langdurige arbeidsongeschiktheid en tot het verstrakken van voorzieningen ten behoeve wan da bevordering van de arbeidsges schiktheid en de levensonstandigheden.

verzekering van werknemers fegen de geldelijke gevolgen van werkloosheid. 


\begin{tabular}{|c|c|}
\hline Wat & Uitwoeringsorganisatie \\
\hline \multicolumn{2}{|c|}{ Volkswerzekeringen: } \\
\hline MOW & SVB (Sociale Verzekeringsbank \\
\hline AWW & SVB \\
\hline $\mathrm{AKW}$ & SVB \\
\hline AWBZ & $\begin{array}{l}\text { Ziekenfiondsen, Partículire Ziektekosten- } \\
\text { werzekeraars }\end{array}$ \\
\hline AAW & BW (Bedrijfswereniging) \\
\hline \multicolumn{2}{|c|}{ Werknemersverzekeringen: } \\
\hline $2 W$ & $B V$ \\
\hline WAO & BV \\
\hline NWW & BV \\
\hline ZFW & Ziekenfondsen \\
\hline WAMLL & BV voor de overheidsdiensten \\
\hline
\end{tabular}

Sociale Zekerheidswetten (niet zijnde werzekeringen):

Algemene Bijstandswet (1965) AlBW

Wet Werkloosheidswoorziening (1965) WWV

Rijksgroepsregeling Werklkze Werknemers (1965) RWW

Wet Inkomenswoorziening Oudere en gedeeltelijk Arbeidsongeschikte Werklloze werknemers (1987) IOAW

Wet Inkomenswoorziening Oudere en gedeeltelijk Arbeidsongeschikte Zetfstandigen (1987) IOAZ

Toeslagenwet (1987) TW financiële ondersteuning op minumumaiveau (bijstand) aan ingezetienen, die niet over de middelen beschikken om in de noodzaw kelijke kosten van het bestaan te voorzien.

inkomenswoorzicaing voor werkloze werknemers in aansluiting op of in plaats van WW-uitkering. Deze wet is per 1 januari 1987 vervallen.

bijstandsuitkering voor diegenen die voor hun levensonderhoud zijn aangewezen op arbeid in loondienst.

inkomensvoorziening op minimumniveau woor bedoelde personen, onafhankelijk van de omvang van het persoonlijke vermogen.

inkomensvoorziening op minimumniveau voor bedoelde groep. onafhankelijk van de omvang van het persoonlijke vermogen.

inkomensaanvulling tot aan het sociale minimum op uitkering op grond wan de ZW, WW, WAO en AAW. 
Naast deze wetten, die uitkeringen werstrekken, kunnen nog worden genoemd:

Wet Sociale Werkwoorziening (1969) WSW

Wet Arbeid Gehandicapte Werknemers (1986) WAGW geven van gelegenheid tot verrichten van betaalde arbeid onder aangepaste omstandigheden voor hen die er niet in slagen on onder normale omstandigheden arbeid te werrichten.

bevordering van de deelname van gehandicapten aan het reguliere arbeidsproces, ondermeer door bet treffen van voorzieningen tot aanpassen van de werkplek en de verplichting tof indienstneming.

\begin{tabular}{l|l}
\hline Wet & Uitvoeringsorganisatie \\
\hline ABW & GSD (Gemeentellike Sociale Dienst) \\
RWW & GSD \\
(WWV) & GSD \\
IOAW & GSD \\
IOAZ & GSD \\
WSW & de Gemeenten \\
TW & BV (Bedrijfsvereniging) \\
WAGW & BV \\
\hline
\end{tabular}


Bijlage 2. Overzicht Bedrijfsvereningen naar administratiewijze: zelfstandig administrerend $(\mathrm{ZA})$ of administratie opgedragen aan het Gemeenschappelijk Administratiekantoor (GAK), onder vermelding van $B V$-nummer

1. Bedrijfsvereniging voor de Tabaksverwerkende en Agrarische Bedrijuen (BV TAB)

2. Bedriffswereniging voor de Zuiwelindustrie

3. Bedrijfsvereniging woor de Bouwnijverheid (BV BOUW)

GAK

4. Bedriffswereniging woor de Hout- en Meubelindustrie en Groothandel in Hout

GAK

8. Graftsche Bedriffsvereniging

GAK

10. Bedriffsvereniging voor de Metaalindustrie en de Electro-technische Industrie

GAK

11. Bedrijfswereniging woor de Metaalnijwerheid

GAK

15. Bedrijfswereniging woor het Bakkersbedrijf

16. Bedrijfsvereniging woor het Slagers- en Vleeswarenbedrijf, de Groothandel in Vlees en Pluimveeslachterijen "De Samenwerking"

18. Bedrijfsvereniging voor de Detaillhandel, Ambachten en Huishoudelijk Personeel (DETAM)

19. Bedrijfsvereniging voor de Haven- en aanverwante bedrijven, Binmenscheepvaart en Visserij

20. Bedriffswereniging woor de Koopvaardij

21. Bedrijfswereniging voor het Verwoer

22. Bedrijfswereniging voor Hotel-, Restaurant-, Café, Pension-en Aanverwante Bedrijwen

23. Bedrijfswereniging voor de Gezondheid, Geestellike en Maatschappelijké Belangen ( $B V G$ )

24. Berlrijfsvereniging voor de Overheidsdiensten

25. Bedrijlswereniging voor Bank- en Verzekeringswezen, Groothandel en Vrije Beroepen

27. Nieuwe Industriêlle Bedriffsvereniging (NIBv)

- De Bedrijfsvereniging voor de Tabakverwerkende en Agrarische Bedrujven is per 01.04.91 ontstaan uit de stmenvoeging wan de voormalige Bedrijfswereniging voor het Agrarisch Berijf (BV Iy en de Bedrijtsvereniging voor de Tabakwerwerkende Industrie (BV 14).

* De Nieuwe Industriele Bedrijfsvereniging is per 1.1 .91 ontstaan uit de voormalige Bedrijfsvereniging voor de Textelindustrie (BV 5), Bedrijfsvereniging voor de Steen-, Cement-, Glas- en Keramische Industrie (BV 9), Bedrijfsvereniging voor de Chemische Industrie (BV 13), Bedrijfsvereniging voor de Voedings- en Genotsmiddelenindustrie (BV 17) en delen van de Nieuwe Algemene Bedrijfsvereniging (BV 26). 


\section{Bijlage 3. Taakopvattingen, overzicht vragenclusters}

4. gevalshehandielling, beoordelen.

Cluster 1: controlegerichtheid. Dit cluster geeft aan in welke mate het handelen wan de verzekeringsgeneeskundige en bedrijfsarts/verzekeringsgeneeskundige in het licht stat van de controle. Dit cluster maakt onderscheid in taakgerichtheid tussen sterk controlerend beoordelen en niet of weinig controlerend beoordelen en bevat de volgende stellingen:

5.2 Ten aanzien van frequent kortdurend verzuim wind ik actieve vg interventie door mij gewenst.

5.5 Mijn woornaamste taak is het voorkomen van oneigenlijk gebruik van zw/wao/ip.

5.6 Ik wind dat er tegenwoordig bij veel werknemers de neiging bestaat oneigenlijk gebruik te maken van de ziektewet.

5.7 Mijn taak is de periode van arbeidsongeschiktheid zo kort mogelijk te houden.

5.12 Ik behoor in de regel patiënten binnen een ao-duur van twee weken niet the beoordelen.

5.35 Door de hoogte van de uitkering of behoud wan salaris tijdens arbeidsongeschiktheid worden patienten niet of onwoldoende gestimuleerd tot werkhervatting.

Cluster 2: het betrekken wan omgevingsfactoren bij de beoordeling. Dit cluster geeft aan of en in welke mate de werzekeringsgeneeskundige en bedrijfsarts/verzekeringsgeneeskundige omgevingstactoren als werk-, gezins- en familieonstandigheden en sociaal-maatschappelijke omstandigheden laat meewegen bij zijn oordeelsvorming. Dit cluster maakt onderscheicl tussen een ruïme en enge taakinhoud en bevat de volgende stellingen:

5.9 Ik acht familie- en gezinsomstandigheden in voorkomende gevallen een legitieme reden woor ziektewerzuim bij een overigens gezonde patiënt.

5.16 Ik dien meer wandacht te besteden aan diagnostiek dan aan andere zaken.

5.17 Ik behoor zoveel mogelijk gebruik te maken van diagnostische gegevens mij verstrekt door de huisarts of specialist.

5.29 Ik behoor een duidelijk beeld te hebben van de werkplek van een verzekerde.

5.50 Inzicht in het verzuim in een afdeling/bedrijf is nodig om cen patiënt goed te kunnen begelejden.

5.66 Om gericht te kunmen begeleiden streef ik naat imzicht in de sociale en matschappelijke achtergronden van de patiênt.

b. gevalsbehandeling, begeleiding

Cluster 3: het adviseren van de patiennt. Dit cluster geeft asn of de verzekeringsgeneeskundige of bedriffsarts/verzekeringsgeneeskwndige het adviserem van patiënten met betrekking tot het gebruik van medische woorzieningen tot zijn/har taak rekenen. Het maakt wat de taakomvang betreft onderscheid 
tussen wel of niel willen adwiseren.

Het cluster beval de volgende stellingen:

5.67 Mijn taka is hei stimuleren van werzekerden on selectief gebruik te maken van medische voorzieningen.

$5.68 \mathrm{lk}$ wind dat ik verzekerden moet stimuleren orn verantwoord gebruik te maken wan medische woorzieningen.

Cluster 4: het betrekken van omgevingsfactoren bij de begeleiding. Dit cluster geeft aan of de verzekeringsgeneeskundige of bedrijfsarts/verzekeringsgeneeskundige zijn begeleidende activititen uilstrekt tot de omgeving wan de patiënt. Het maakt op hat aspect taakinhoud onderscheid wel of niet op de omgeving van de patiët anticiperende begeleiders en bevat de volgende stellingen:

5.11 Ik moet de patient duidellik maken dat ik mij in hoofdzaak bezig houd met zijn/haar lichamelijk welbevinden.

5.18 lk behoor de patiènt te informeren over de sociale wetgeving (arbeidsongeschiktheidswetten)

5.35 Ik behoor bij tijdelijke werkanpassingen owerleg te plegen met de directe chef van verzekerdie.

5.37 $\mathrm{lk}$ moet in woorkomende gevalten aktief een gesprek tussen werkmemer en leiding bevorderen.

$5.53 \mathrm{lk}$ bemoei mij in de regel niet met de oplossing van relationele problemen tussen werknemer en werkgever.

5.56 Zolang een werzekerde onder behandeling is bij huisarts of specialist, wacht ik af en intervenieer niet.

Cluster 5: het coördineren van curatieve interventies. Dit cluster geeft aan of en in welke mate de verzekeringsgeneeskundige of bedrijfsarts/verzekeringsgeneeskundige de door de huisarts of specialist ingestelde therapiën wil beïnvloeden. Het geeft zicht op een taakinhoudelijk aspect: strekt de verzekeringsgeneeskundige begeleiding zich uit tot een afstemming met de curatieve therapie of is er sprake van een strikte scheiding van verzekeringsgeneeskundige begeleiding en curatieve therapie. Dit cluster maakt onderscheid tussen de opvattingen dat coördinatie wel of niet noodzakelijk wordt geacht. Dit cluster bevat de volgende stellingen:

5.14 Het is mijn voornatmste tak ervoor zorg te dragen dat de behandeling door de curatieve sector zoveel mogelijk op de werkhervatting gericht is.

5.25 Ik heb geen of nauwelijks inwloed op de door de huisarts of specinalist ingestelde behandeling.

5.47 De coördinatie wan interventies, ingesteld door de curatieve sector, behoort tot mijn takak.

5.48 Het behandelingsheleid van de curatieve sector moet actief door mij beinvloed kunnen worden.

\section{c. Groepsbehandeling: oordelen}

Cluster 6: het willen betrekken van bedrijtsinformatie bij de oordeelsvorming. Dit cluster geeft aan of en in welke mate de verzekeringsgeneeskundige of bedriffsarts/werzekeringsgeneeskundige bij de witoefening van de preventiefunctie behoefte heef aan bedrifsinformatie uit andere bron dan de 
patient. Het betreft hier aen aspect van de takonvang: reken ith de verzumpreventie al of aiet tot mijn taak. Dit cluster bevat de volgende stellingen:

5.1 Om mign preventie goed te kumen witvoeren zou ik de beschikking moeten hebben over verzuimcijfers wan de aan mijn zorg toevertrouwde bedrijpen.

5.3 Frequent kortdurend wercuim beschouw ik als een viting wan een slechte, inefficiènte orgatuisatie van het bedriff.

5.4 Freguent kortdurend verzuim beschouw ik als een viting wan relationele problemen in het werk.

5.10 Inzicht in het verzujm van een bedrijf is noodzakelijk om het bedrijf adequaat te kumen adviseren.

5.34 Door contacten net werknemers heb ik voldoende inzicht in de aard en omwang wan het verzuim in het bedriff.

$5.61 \mathrm{lk}$ vind dat ik maatschappelijke factoren als oorzak wan ziekteverzuim behoor te signaleren.

\section{d. groepsbehandeling, preventie}

Cluster 7: in hoeverre wordt preventie tot een van de taken gerekend. Dit cluster geeft asn of en in welke mate de verzekeringsgeneeskundige of bedrijfsarts/verzekeringsgeneeskundige de prewentie, gericht op groepen werknemers tot zijn/haar taak rekent. Dit aspect van de taakomvang betreft die activiteiten welke zich richten op groepen werknemers (bedriff, afueling) een het voorkomen wan ziekteverzuim door informatie en adviezen te bewerkstelligen. Dit cluster bevat de volgende stellin gen:

5.13 Ik reken preventie tot een van mijn taken.

5.15 Overleg met de bedrijfsleiding over verbetering van de arbeidsomstandigheden behoort tot mijn taak.

5.28 Tot een belangrijke taak behoren activiteiten, gericht op verandering van de arbeidsomgeving.

5.40 lk moet een verzekerde kunnen oproepen, ook indien er geen sprake is van een zieknelding.

5.54 Het voorkomen wan ziekteverzuim reken ik tot mijn belangrijkste taak.

5.60 Tot mijn taak behoon het geven van ergonomische adviezen (zoals: werkhouding, dragen wan gehoorbescherming).

Cluster 8: het betrekken van het bedrijf bij de uitvoering wan de preventietaak. Dit cluster bevat een tawkinhoudelijk aspect en geeft aan of en in welke mate de verzekeringsgenecskundige of bedijfsarts/ verzekeringsgeneeskundige bereid is het bedrijf te betrekken bij de uitwoering van de proventiefunctie.

Beschouw hij ondersteuning vanuit en samenwerking met het bedrijf als noodzakelijk en gewenst? Dit cluster bevat de volgende stellingen: 
5.36 thehoor in workomende gevallen het bedrift te adviseren naar anleiding van niet optimale werkomstundigheden.

$5.39 \mathrm{lk}$ wind het nuttig in de bedrijwen waarwoor ik werkzaam ben spreekuur te houden.

5.41 Ik vind dat ik betrokken moet worden in het social-ieam-overleg (personeelszaken, bedrijfsmatschappelijk werk, leiding binnen het bedrijt.

5.43 Voor een gerichte ziektebegeleiding is een goede relatie met de bedrijfsleiding noodzakelijk.

\section{C1 Condities met betrekking tot de gevals- en groepsbehandeling}

Cluster 9: materiale en immaterielle hulpmiddelen. Dit clustar geeft aan of en in welke mate er materiële en immateriatle hulpmiddelen ten behoeve wan de gevallsbehandeling in de werkomgeving van de werzekeringsgeneeskundige en bedrijfsarts/verzekeringsgeneeskundige aanwezig zijn. Het betreft hier niet de wraag of deze hulpmiddelen er zijn, wel of deze hulpmiddelen er naar de mening van de verzekeringsgeneskundige of bedrijfsarts/verzekeringsgeneeskundige in voldoende of onvoldoende mate zijn. Dit chuster bevat de volgende stellingen:

5.22 Nanar mijn mening kan mijn diagnostiek door tijdsgebrek niet zo uitgebreid zijn als ik wel zou willen.

5.31 Naar mijn mening beschik ik over onvoldoende hulpmiddelen om mijn diagnostiek zo te ver-richten als ik wel zou willen.

5.33 Ik beschik in mijn dagelijks werk vaak over te weinig tijd om een gerichte reïntegratie tot stand te brengen.

5.65 Bij de uitoefening van mijn taak beschik ik over onvoldoende diagnostische hulpmiddelen.

Cluster 10: Vertrouwensrelatie met de patiënt. Dit cluster of sen vertrouwensrelatie met de patient noodzakelijk wordt geacht door de verzekeringsgeneeskundige of bedrijfsarts/verzekeringsgeneeskundige. Dit cluster bewat de volgende stellingen:

5.23 Ik vind een vertrouwenstelatie tussen arts en patiënt een voorwaarde voor een goede verzekeringsgeneeskundige begeleiding.

5.24. Door het ontbreken van een vrije artsenkeuze in de sociale geneeskunde komt deze vertrouwenstelatie onwoldoende tot stand.

Cluster 11: de relatie met de curaticve sector en het bedrijf. Dit cluster geeft aan of en in welke mate de verzekeringsgeneeskundige of bedrijfsarts/verzkkeringsgeneeskundige een goede werkrelatie met de omgeving (bedrijf, curatieve sector) als voorwarde beschouwd voor een goede verzekeringsgenetskundige begeleidng. Dit clusier bevat de volgende stellingen:

5.44 Ik wind het ongewenst dat een bedrijf invloed uitoefent op mijn ziektebegeleiding.

5.57 Om gericht te kunnen begeleiden acht ik esn goede professionele relatie tussen mij en de behandelend arts onontbeerlijk.

5.58 Mijn beleid wordt vauk doorkruist door een anders gerichte hulpverlening van de huisarts of specialist. 
5.59 IK beschouw de scheiding wan behandeling en controle een voorwatrde voor gericht vertekeringsgeneeskundig begeleiden.

5.64 Ik vind dat bet beleid bij ziekteverzum nieer het resultaat moet zijn wan gezanienlijk owerleg tussen huisarts en socialal geneeskundige ( $\mathrm{g} / \mathrm{ba}$ )

Cluster 12: de relatie met het bedrij. Dit cluster geft aan of en in welke nate er in de relatie met het bedrijf woldoende condities aanwezig zijn om patiënten te kunnen reintegreren. Dit cluster bevat de volgende stellingen:

5.20 Ik ervaar bij het tot stand brengen van reintegraties in de regel te weinig medewerking van de kant van het bedrijf.

5.42 Ik moet de bekwaamheid hebben om ergonomische adviezen uit te brengen.

Cluster 14: de oordeelsvorming. Dit cluster geeft aan op welke wijze de verzekeringsgeneeskundige of bedrijfsarts/verzekeringsgeneeskundige tot een oordeel komt en maakt onderscheid tussen de zakelijke, sterk op de wetsuitwoering gerichte oordeelsvorning en de anticiperende, mees op de patiënt gerichte oordeelsworming. Dit cluster bevat de volgende stellingen:

5.8 Ik moet in mijn oordeelsworming niet alleen de anamnestische gegevens en onderzoeksresultaten betrekken, maar ook het gedrag van de patiënt.

5.26 Mijn diagnostiek moet in hoofdzaak gericht zijn op het onderkennen van potentiëel-langdurig arbeidsongeschikten.

5.45 In mijn oordeelsworming over arbeidsongeschiktheid laat ik mij sterk leiden door de mening van de patiënt.

\section{Visie op de taakonvang}

Cluster 13: meting van de takomvang. Dit cluster geeft aan of en in welke mate de werzekeringsgeneeskundige of bedrijfsarts/verzekeringsgeneeskundige naast gevalsbehandeling preventie en het verzekeringsgeneeskundig consulentschap ten behoeve van de curatieve sector als taak ziet. Dit cluster bevat de volgende stellingen:

5.19 Het analyseren wan de werksituatie behoort tot mijn taak.

$5.27 \mathrm{lk}$ heb geen of nauwelijks invloed op de arbaidsongeschiktheidsduur.

5.38 In bedrijwen, waaraan geen bedrijfsarts verbonden is, behoort prewentie tot een der verzekeringsgeneeskundige taken.

5.46 $\mathrm{lk}$ dien ten aanzien van mijn handelen directe verantwoording verschuldigd te zijn asn het bedrijf.

5.62 Ik wind dat huisartsen zich onvoldoende met werkproblemen bezighouden.

5.63 lik vind mijzelf de consulent bij uitstek mat betrekking tot sociale verzekeringen ten behoove van de eerste en tweede lijns gezondheidszorg. 
Bijlage 4. Statistische kenmerken taakopvattingsclusters: items en factorladingen op geroteerde factormatrix.

\begin{tabular}{|c|c|c|c|}
\hline items & factor 1 & factor 2 & factor 3 \\
\hline 1. controlegerichtheid & -0.62 & 0.15 & 0.13 \\
\hline 2. omgevingstactoren & -0.01 & 0.48 & 0.12 \\
\hline 3. advisering & 0.16 & 0.64 & -0.30 \\
\hline 4. omgewing gactiviteiten & 0.47 & 0.19 & 0.20 \\
\hline 5. coordinatie & 0.06 & 0.62 & 0.12 \\
\hline 6. groeppsanalyse & -0.10 & -0.01 & 0.54 \\
\hline 7. preventie & 0.65 & 0.53 & 0.13 \\
\hline 8. bedrigfsrelatie & 0.85 & 0.23 & 0.06 \\
\hline 9. hulpmiddelen & -0.22 & 0.55 & -0.08 \\
\hline 10. vertrouwenstalate & 0.39 & -0.27 & -0.53 \\
\hline 11. relatie met curatieve sector & 0.56 & -0.32 & -0.03 \\
\hline 12. medewerking bedrijf & 0.31 & -0.04 & 0.73 \\
\hline 13. trakopvang & 0.73 & -0.10 & -0.13 \\
\hline 14. oordeelsvorming & -0.43 & 0.43 & -0.39 \\
\hline verklaarde wariantie in $\%$ per factor & 22.4 & 15.0 & 10.5 \\
\hline $\begin{array}{l}\text { gesemmearde verklatrde variantie in } \\
\text { o per facton }\end{array}$ & 22.4 & 37.4 & 47.9 \\
\hline
\end{tabular}




\section{Bijlage 5. Overzicht van in onderzoek betrokken diagnosen, geco- deerd volgens International Classification of Diseases, 9th revision, 1975.}

\begin{tabular}{|c|c|c|c|}
\hline 0 & $*$ & $*$ & $*$ \\
\hline
\end{tabular}

\section{PSYCHISCHE ZIEKTEN}

0290 dementie

0295 schizofrenie

0296 manisch-depressieve psychosefinvolutie depressie

0298 overige en niet gespecificeerde psychosen

0300

$$
\begin{array}{ll}
\text { neurosen; } \quad \text { inclusies: } & \text { phobies } \\
& \text { hysterie } \\
& \text { neurotische depressie } \\
& \text { neurasthenie } \\
& \text { poging tot zelfoding }
\end{array}
$$

0301

persoonlijkheidsstoomissen (personality disorders)

inclusies: psychopathie

gestoorde karakterstructuur (cyclothym,

dystym, agressief, querulerend)

exclusies: constitutionele nervositas

alcolholwerslaving drugverslaving fysiologische functiestoornissen door psychische onrzaken

$\begin{array}{ll}\text { inclusies: } & \text { hyperventilatie syndroom } \\ & \text { hartneurose } \\ & \text { psychosomatose } \\ \text { exclusies: } & \text { migrane } \\ & \text { hyperemesis grawidarum } \\ & \text { functiestoonissen darm }\end{array}$

anorexia nervosa

situatieve of exogene reactie inclusies: reactieve depressie reactie op stress (echtscheiding, ontslag, fiallisement) surmenage door overbellasting

0317 zwakbegaafdheid/debilitas

031.8 imbecilitas en idiotie 


\section{ZIEKTEN VAN HET HART-EN VATSTELSEL}

0390 acult reumb zonder harkfwijkingen

0391 achut reumet wet hartatwitingen

0396 reumatische hariziakten

inclusic: chorea minor

0401 hypertensie

0410 acuut myocandinfarct

0413 angine pectoris

0414 overige chronische ischemische bartiekten

inclusie: coromairsclerose

$0415 \quad$ Hongernbolie

0416 cor pulmonale

0427 ritmestoornissen

0428 decompensatio cordis

0429 overige en niet gesperficeerde hartxiekten

$0430 \quad$ subarachnoüdate blowing

0426 werebrowasculair accident exclusie: parese door andere andoeningern

0437 overige en niet gespecificeerde andowningen van de hersenvaten.

$0440 \quad$ atherousclerose

0443 ziekte van Raynat, ziekte van Buerger (tromboangitis oblitenans) acrocyanose, acroparesthesie, elaudicatio intermintens

045 : flebitis of tromboflebitis

0454 waricosis van de benen met en zonder ulceratie

0455 hemorroïden

0456 varices elders: oesofugus, waricocele

0458 hypotensie n.n.o.

0459 overige en niet gespecificeerde ziekten wan het hat- en vaatstelsel.

\section{ZIEKTEN VAN DE ADEMHALINGSWEGEN}

0462 acute faryngitis

0465 overige an met gespecificerde acute infecties van de bo-wenste luchtwegen

0472 chronisehe faryngitis

0473 sinusitis

0474 chronisehe tonsillitis

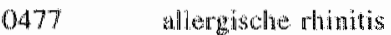

0486 prenmonie

$$
\text { inclusie: hooikoorts }
$$

$048^{*}$ influenza

0490 acute bronchitis

0491 chronische bronchitis

0492 enfyseem

0493 astma

$$
\begin{array}{ll}
\text { inchusies: } & \text { atopic } \\
& \text { allergisch } \\
& \text { gecombineard met hooikoorts }
\end{array}
$$


0512 pneumothorax

0519 overige en niet gespecificerde ziekten van de adembilingswegen

$\begin{array}{lll}\text { exclusies: } & \text { ziekte van Besmier-Boeck } & 0135 \\ & \text { hyperventilatie } & 0306 \\ & \text { longembolie } & 0415 \\ & \text { astma cardiale } & 0428\end{array}$

\section{ZIEKTEN WAN HET BEWEGINGSSTELSEL}

0710 collageenziekten

0712 jicht

0714 primair chronisch reuma (c.q. chronische reumatische artritis)

0715 artrosis deformans

0717 meniscuslaesie van de knie

0719

0720

0721

0722

0723

0732

0737

0724

0726

0728

0729

0730

0732

0733

0736

overige en niet gespecificeerde gewrichtsklachten

exclusies: acuut reuma zonder hartafwijkingen acuut reuma met hartafwijkingen

ziekte wan Bechterew (spondylosis ankylopoëtica)

spondyloartrosis

discopathie met of zonder complicaties

nekklachten

ziekte van Scheuermann

kyfoscoliose

overige en niet gespecificeerde rugaandoeningen

inclusies: lumbago

ischias

exclusies: neuritis van de $\mathrm{n}$. ischiadicus

0355

aangeboren misvormingen als

0756

spondylolysis, spondylolysthesis,

cong. kyfoscoliose

pees-en spierranhechtingsklachten, o.a.

periartritis humeroscapularis

tenniselleboog

tendo-vaginitis Achillewa

ziekte wan Dupuytren

myalgie, neuralgie

osteomyelitis, niet specifiek.

ziekte van Osgood-Schlatter en andere osteochondropathieën

osteoporose

overige verworven afwijkingen van de extremiteiten exclusies: aangeboren miswormingen als: congenitale heupluxatie

pes equinuss 


\section{ONGEVALLEN}

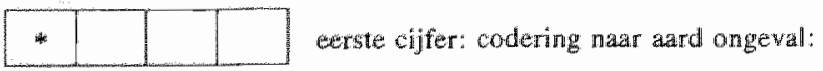

0 geen ongeval

1 bedrijfsverkeersongeval

2 owerig bedriffongeval

3 overig verkeersongeval, geen bedriffsverkeersongewal zijnde

4 sportongeval buiten het bedrijf

5 huisonigeval

6 ongewal in openbare gelegenheid

8 overige ongevallen

9 ard/oorzaak onbekend

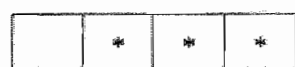

Fracturen 803

807

808

809

810

813

816

817

818

821

822

823

824

825

826

827

829

Luxaties 831

834

835

839

cijter $2 t / m$ : codering ongewalsdiagnose:

schedel

rib of ribben

bekken

overige rompfracturen

clavicula

onderarm en/of pols

alleen vinger(s)

middenhand + vinger(s)

overige en niet specificeerde armfracturen

femur

patella

onderbeen

enkel

middenwoet + teen (tenen)

teen(tenen) alleen

overige en niet gezpecificeerde beenf racturen

overige en niet gespecifieerde fracturen van beenstukken.

schouder

vinger(s)

heup

overige en niet gespecificeerde luxaties:

Verstuikingen en verrekkingen

845

847

enkel of woet

whiplash

848

overige en niet gespecificeerde verstuikingen en verrekkingen

Inwendig letsel

850

854

commotio cerebri

869

overige en niet gespecificeerde intracraniële letsels

borst, buik en bekken 
Open wondan

\begin{tabular}{|c|c|}
\hline 871 & $\operatorname{ogg}$ \\
\hline 873 & boofd an hals \\
\hline 879 & romp \\
\hline 884 & arm \\
\hline 891 & $\begin{array}{l}\text { been } \\
\text { axclusie: }\end{array}$ \\
\hline
\end{tabular}

Traumatische amputaties (ook partiee)

$\begin{array}{ll}885 & \text { duin } \\ 886 & \text { vinger(s) } \\ 887 & \text { arm } \\ 895 & \text { teen(tenen) } \\ 896 & \text { voet } \\ 897 & \text { been }\end{array}$

Oppervlakkige wonden

919 oppervlakkige wonden

Contusies en kneuzingen

$\begin{array}{ll}924 & \text { contusies } \\ 929 & \text { "crush"letsel }\end{array}$

Verbrandingen (warmte, straling, etsing)

$\begin{array}{lll}940 & \begin{array}{l}\text { oog } \\ \text { exclusie: lasogen }\end{array} \\ 941 & \text { hoofd en hals } \\ \text { romp } & \\ 942 & \text { arm } \\ 943 & \text { hand en/of pols } \\ 944 & \begin{array}{l}\text { been } \\ \text { inclusies: }\end{array} \\ 945 & \text { meervoudige localisaties }\end{array}$

Vergiftigingen

977 geneesmiddelen intoxicatie

989 overige intoxicaties

Allergische reacties

995

allergische reachies

axclusies: allergische rhinitis n.n.o., incl. hooikoorts

astma, incl. atopie, allergisch, gecombineerd met hooikonts

(contact)dermatitis 
Bijlage 6. Statistische kenmerken beoordelingsitems vg en ba/vg bij le en laatste su-beoordeling.

\begin{tabular}{|c|c|c|c|c|c|}
\hline & & \multicolumn{2}{|c|}{ w-beoordeling } & \multicolumn{2}{|c|}{$\mathrm{ba} / \mathrm{vg}$-beoordeling } \\
\hline & & le & labaste & le & laatste \\
\hline \multicolumn{6}{|l|}{ diagnose } \\
\hline \multirow[t]{2}{*}{ range } & hoog & 6.00 & 6.00 & 6.00 & 6.00 \\
\hline & laag & 1.00 & 1.00 & 1.00 & 1.00 \\
\hline gemiddelde $X$ & & 3.75 & 3.58 & 3.70 & 3.78 \\
\hline SD & & 1.84 & 1.85 & 11.87 & 1.89 \\
\hline \multicolumn{6}{|c|}{ begeleidingsplan } \\
\hline \multirow[t]{2}{*}{ range } & hoog & 7.00 & 7.00 & 7.00 & 7.00 \\
\hline & laag & 1.00 & 1.00 & 1.00 & 1.00 \\
\hline gemiddalde $X$ & & 2.37 & 2.33 & 3.38 & 3.08 \\
\hline SD & & 1.81 & 2.08 & 1.90 & 2.02 \\
\hline \multicolumn{6}{|l|}{ conclusie } \\
\hline \multirow[t]{2}{*}{ range } & hoog & 7.00 & 7.00 & 7.00 & 7.00 \\
\hline & laag & 1.00 & 1.00 & 1.00 & 1.00 \\
\hline gemiddelde $X$ & & 3.87 & 3.33 & 3.68 & 3.41 \\
\hline SD & & 1.53 & 1.71 & 1.44 & 1.55 \\
\hline \multicolumn{6}{|l|}{ prognose } \\
\hline \multirow[t]{2}{*}{ range } & hoog & 4.00 & 4.00 & 3.00 & 4.00 \\
\hline & laag & 1.00 & 1.00 & 1.00 & 1.00 \\
\hline geniddelde $X$ & & 1.24 & 1.40 & 1.20 & 1.34 \\
\hline $\mathrm{SD}$ & & 0.78 & 0.94 & 0.44 & 0.83 \\
\hline \multicolumn{6}{|c|}{ raadplegen huisarts } \\
\hline \multirow[t]{2}{*}{ range } & hoog & 2.00 & 2.00 & 2.00 & 2.00 \\
\hline & latag & 1.00 & 1.00 & 1.00 & 1.00 \\
\hline gemiddelde $x$ & & 1.15 & 1.19 & 1.08 & 1.17 \\
\hline $\mathrm{SD}$ & & 0.36 & 0.49 & 0.31 & 0.25 \\
\hline \multicolumn{6}{|c|}{ rundplegen specislist } \\
\hline \multirow[t]{2}{*}{ range } & hoog & 2.00 & 2.00 & 2.00 & 2.00 \\
\hline & litag & 1.00 & 1.00 & 1.00 & 1.00 \\
\hline gemiddelde $X$ & & 1.46 & 1.34 & 1.40 & 1.30 \\
\hline $\mathrm{SD}$ & & 0.50 & 0.48 & 0.49 & 0.47 \\
\hline
\end{tabular}




\section{Bijlage 7 Correlatie tussen onafhankelijke variabelen en de afhanke- lijke variabele (ao-duur) én onafhankelijke variabelen onderling van de onderzoekspopulatie.}

1. Onderzoekspopulatie, alle diagnosegroepen, $\mathrm{N}=206$

afhankelijke varabele:

onafhankelijke wariabele: ao-duur

0. verzekerngsgentekkundige

1. wamtal college-artsen

2. axantal su-patienten per weok

3. datum indienstreding

4. bij-an nascholing

5. intercollegiale toetsing

6. tevredentheid met werk

7. bedrajts-wg

8. indiv., $-v g$

9. groeps $-\mathrm{vg}$

10. geboortejaar patiönt

11. specialist geradpleegd door put.

12. opleidingsnivean patiënt

13. zwaste wark patient

\begin{tabular}{|c|c|c|c|c|c|c|c|c|c|c|c|c|c|c|c|}
\hline & ao-dunr & 0 & 1 & 2 & 3 & 4 & 5 & 6 & 7 & 8 & 9 & 10 & 11 & 12 & 13 \\
\hline 0 & 17 & & & & & & & & & & & & & & \\
\hline 1 & -22 & -.01 & & & & & & & & & & & & & \\
\hline 2 & -.23 & 38 & .09 & & & & & & & & & & & & \\
\hline 3 & .07 & -.16 & .08 & -.22 & & & & & & & & & & & \\
\hline 4 & -.24 & -.40 & .07 & -.02 & .34 & & & & & & & & & & \\
\hline 5 & -.07 & -.10 & .14 & .08 & .07 & .22 & & & & & & & & & \\
\hline 6 & .07 & .17 & .06 & 12 & -.07 &. .17 & .02 & & & & & & & & \\
\hline 7 & .24 & .63 & .05 & .03 & .02 & -.23 & .09 & .03 & & & & & & & \\
\hline 8 & .04 & .05 & -.26 & -.03 & -.47 & .03 &. .17 & .11 & .15 & & & & & & \\
\hline 9 & .09 & -14 & -.06 & -.19 & -.18 & -10 &., 07 & -.11 & -.26 & .06 & & & & & \\
\hline 10 & .02 & .09 & .11 & .04 & .07 & .03 & .02 & .04 & .06 & -.09 & .08 & & & & \\
\hline 11 & -12 & .02 & .05 & .08 & .00 & .04 & .02 & .04 & -.03 & .04 & -.06 & -.02 & & & \\
\hline 12 & .10 & -.17 & -.13 & -.38 & -.01 & -.10 & .00 & -.15 & -.03 & .13 & .16 & .09 & -.09 & & \\
\hline 13 & -.09 & -.17 & -.03 & -.15 & -.13 & .04 &., 02 & -.01 & -.11 & .13 & .10 &. .02 & -.07 & .27 & \\
\hline
\end{tabular}


2. Onderzoekspopulatie, witshitend door $\mathrm{kg}$ verzorgd, alle diagnosegroepen, $\mathbb{N}=163$

afhankeligke variabele:

onathankelijke variabele: aoduer

1. aantal college-artsen

2. aantal su-patiënten per week

3. datum indiensttreding

4. bij-en nascholing

5. intercolleginle toetsing

6. tewredenheid met werk

7. bedrijfs-vg

8. indiv. $-\mathrm{wg}$

9. groeps-vg

10. gebortejaar pattênt

11. specialist geraadpleegd door pat.

12. opleidingsniveau patiënt

13. zwaarte werk patiènt

\begin{tabular}{|c|c|c|c|c|c|c|c|c|c|c|c|c|c|c|}
\hline & aondur & 1 & 2 & 3 & 4 & 5 & 6 & 7 & 8 & 9 & 10 & 11 & 12 & 13 \\
\hline 1 & -.23 & & & & & & & & & & & & & \\
\hline 2 & -37 & .13 & & & & & & & & & & & & \\
\hline 3 & .12 & .04 & -20 & & & & & & & & & & & \\
\hline 4 & -.22 & .10 & .16 & .36 & & & & & & & & & & \\
\hline 5 & .09 & .20 & .03 & .11 & .38 & & & & & & & & & \\
\hline 6 & -.10 & .08 & .03 & -.06 & -.16 & -.03 & & & & & & & & \\
\hline 7 & .19 & .10 & -.38 & .14 & -.10 & .22 & -14 & & & & & & & \\
\hline 8 & .03 & -.34 &. .02 & -.51 & -.02 & .09 & .12 & 15 & & & & & & \\
\hline 9 & .13 & -.04 & -.16 & -.22 & -.08 & -.21 & -.08 & -13 & .12 & & & & & \\
\hline 10 & .02 & .10 & -.09 & .08 & .01 & -.01 & .03 & .04 & -12 & .09 & & & & \\
\hline 11 & -.13 & .03 & $\$ 1$ & .00 & .05 & .07 & .05 & .04 & .01 & -.06 & .02 & & & \\
\hline 12 & .18 & -.17 & -36 & -.06 & -.20 & .03 &. .08 & .19 & .15 & .14 & .07 & -.09 & & \\
\hline 13 & -.07 & -.06 & -.10 & -.17 & -11 & -10 & .05 & .02 & .19 & .09 & -.03 & -.07 & .25 & \\
\hline
\end{tabular}


3. Onderzokspopulatie, diagnosegroep: ziekten van het bewegingsstelsel, $N=83$

athankelijk wariabele:

cnafhankelijke variabele:
Do-dunir

1. cantal colloge-urtsen

2. asntal su-phtienten per week

3. dathm indienstreding

4. bij- en nascholing

5 , intereollegialle toetsing

6. tevnedenheid met work

7. bedrijf $\mathrm{s}-\mathrm{vg}$

8. indiw $-v g$

9. groeps-vg

10. geboortejar patient.

11. specialist geradpleegd door pat

12. opleidingsnveau patient

13. cwaarte werk patient

\begin{tabular}{|c|c|c|c|c|c|c|c|c|c|c|c|c|c|c|}
\hline & aomdunr & 1 & 2 & 3 & 4 & 5 & 6 & 7 & 8 & 9 & 10 & 11 & 12 & 13 \\
\hline 1 & -28 & & & & & & & & & & & & & \\
\hline 2 & -.08 & -.06 & & & & & & & & & & & & \\
\hline 3 & .13 & .07 & -.25 & & & & & & & & & & & \\
\hline 4 & -.07 & -.02 & -.23 & .40 & & & & & & & & & & \\
\hline 5 & .08 & .13 & .04 & .08 & .24 & & & & & & & & & \\
\hline 6 & -.06 & .00 & .06 & -.08 & -.16 & -.02 & & & & & & & & \\
\hline 7 & .19 & .07 & .17 & .06 & -.10 & .12 & .02 & & & & & & & \\
\hline 8 & .14 & -.32 & .03 & -.46 & -.04 & -.18 & .10 & .18 & & & & & & \\
\hline 9 & -.07 & -.05 & -.22 & -.24 & -.02 & -.05 & -.10 &. .34 & .17 & & & & & \\
\hline 10 & .15 & .10 & -.14 & .06 & .06 & -.00 & -.10 & -.03 & -.11 & .09 & & & & \\
\hline 11 & -10 & .05 & .18 & -.01 & .18 & .03 & -.05 & -.09 & .02 & -.00 & .01 & & & \\
\hline 12 & .15 & -.08 & -.31 & .03 & -.01 & .13 & -.08 & -.18 & .01 & .23 & .16 & -.14 & & \\
\hline 13 & .08 & .05 & .07 & -.09 &. .08 & .15 & .25 & -.13 & .02 & .18 & -.14 & -.18 & .14 & \\
\hline
\end{tabular}


4. Onderzoekspopuatie, diagnosegrop: owerige diagnosen, $N=78$

andankelijke variabel

ond afankelijke variabele:
an-dusur
1. axintal college-artsen

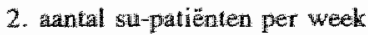
3. datum indienstureding
4. bij- En nascholing
5. untereoullegiale toetsing
6. Hevedentid met werk
7. bedrijfs-vg
8. indiv, -
9. groeps-Wg
10. geboortejaar pationt
11. specialist geraadpleegd door par.
12. opleidingsmiveau patient
13. zwaarte werk patiênt

\begin{tabular}{|c|c|c|c|c|c|c|c|c|c|c|c|c|c|c|}
\hline & ac-duur & 1 & 2 & 3 & 4 & 5 & 6 & 7 & 8 & 9 & 10 & 11 & 12 & 13 \\
\hline 1 & -.10 & & & & & & & & & & & & & \\
\hline 2 & -.50 & .02 & & & & & & & & & & & & \\
\hline 3 & .01 & .09 & $-.2 \|$ & & & & & & & & & & & \\
\hline 4 & -.39 & .14 & .12 & .36 & & & & & & & & & & \\
\hline 5 & -.09 & .18 & .07 & .07 & .20 & & & & & & & & & \\
\hline 6 & -.08 & .07 & .12 & -.07 & -.17 & -.02 & & & & & & & & \\
\hline 7 & .33 & .11 & -.06 & .09 & -.19 & .11 & .02 & & & & & & & \\
\hline 8 & -15 &. .12 &. .01 & -.45 & .07 & -.17 & .14 & .03 & & & & & & \\
\hline 9 & .30 & .06 & -.25 & -.18 & -.23 & -.11 & -.14 & -.14 & .09 & & & & & \\
\hline 10 & -.01 & .12 & -.02 & .07 & -.01 & .15 & .03 & .17 & .04 & .05 & & & & \\
\hline 11 & -.23 & -.03 & .05 & .05 & .02 & .03 & .13 & .05 & .05 & -.08 & .02 & & & \\
\hline 12 & .25 & -.11 & -.37 & -.04 & -.22 & -.16 & -.16 & .04 & .18 & .16 & .08 & .10 & & \\
\hline 13 & .08 & -.11 & -19 & -16 & -.10 & -.16 & -.14 & .14 & .22 & .09 & -.05 & .20 & .24 & \\
\hline
\end{tabular}




\section{LIJST VAN AFKORTINGEN}

\begin{tabular}{|c|c|}
\hline AAW & Algemene arbeidsongeschiktheidswet \\
\hline ABP & Algemeen Burgerlijk Pensioenfonds \\
\hline ABP-wet & Algemeen Burgerlijke Pensioenwet \\
\hline AOW & Bedriffseenheid Arbeidsongeschiktheidsverzekering \\
\hline ARAR & Algemeen Rijksambtenarenreglement \\
\hline ARBO-wet & Arbeidsomstandighedenwet \\
\hline aker & afdelingskas of eigen risicodrager \\
\hline ao-duur & arbeidsongeschiktheidsduur \\
\hline bat & bedrijfsarts \\
\hline balvg & bedrijfsarts/verzekeringsgeneeskundige \\
\hline $\mathrm{BGD}$ & Bedrijfs Gezondheidsdienst \\
\hline BNG & Bedrijfsvereniging voor de Gezondheid, Geestelijke en Maatschappelijke Belangen \\
\hline $\mathrm{CCOZ}$ & $\begin{array}{l}\text { Stichting Coördinatie wan Communicatie met betrekking tot Onderzoek inzake Ziek- } \\
\text { teverzuim }\end{array}$ \\
\hline BV & Bedrijfsvereniging \\
\hline BVG & Bedrijfsvereniging voor de Gezondheid, Geestelijke en Maatschappelijke Belangen \\
\hline DETAM & Bedrijfswereniging voor de Detailhandel, Ambachen en Huisvrouwen \\
\hline DGD & Districtsgezoncheidsdienst \\
\hline DSM & De Staatsmijnen \\
\hline FBV & Federatie wan Bedrijfsverenigingen \\
\hline GAK & Gemeenschappallijk Administratiekantoor \\
\hline $\mathrm{GMD}$ & Gemeenschappelijk Medische Dienst \\
\hline $\mathbb{I C D}$ & International Classification of Diseases \\
\hline ILO & Intermational Labour Office \\
\hline IP & Invaliditeitspensioen \\
\hline mra & multipele regressie-analyse \\
\hline NIA & Nederlands Instituut voor Arbeidsomstandigheden \\
\hline NIBV & Nieuwe Industriële Bedrijfsvereniging \\
\hline NIPG & Nederlands Instituut voor Praeventieve Gezondheidszorg \\
\hline ohd & occupational health-doctor \\
\hline ohd/sid & occupational health-/social insurance-doctor \\
\hline RBB & Rijks Bedrijfsgezondheids- en Bedrijfsveiligheidsdienst \\
\hline RGD & Rijks Geneeskundige Dienst \\
\hline SER & Social Economische Raad \\
\hline SFB & Sociaal Fonds Bouwnijverheid \\
\hline sid & social insurance-doctor \\
\hline$S V_{r}$ & Sociale Verzekeringsraad \\
\hline TAB & Bedrijfsvereniging voor de Tabakswerwerkende en Agrarische Bedrijven \\
\hline vg & verzekeringsgeneeskundige \\
\hline WAO & Wet op de arbeidsongeschiktheidsverzekuring \\
\hline WHO & World Health Organisation \\
\hline WW & Werkloosheidswet \\
\hline ZA-BV & Zelfadministrerende bedrijfsvereniging \\
\hline $\mathrm{ZW}$ & Ziektewel \\
\hline
\end{tabular}




\section{CURRICULUM VITAE}

De auteur van dit proefschrift werd op 7 oktober 1948 geboren te Hilversum. Hij volgde de Middelbare Schoolopleiding aan het Aloysius College te 's-Gravenhage, waar hij in 1968 het eindexamen gymnasium B behaalde.

In dat jaar begon hij aan de Rijksuniversiteit Leiden de studie Geneeskunde. Deze studie werd, na enige jaren onderbroken te zijn wegens het vervullen wan bestuursfuncties op universitair en faculteitsniveau, in januari 1979 afgesloten met het behallen van het artsexamen.

Sedert 1977 was hij werkzaam als hoofd van het Diagnostisch Centrum Utrecht, onderdeel van de Stichting Centraal Artsen Laboratorium, en belast met de coördinatie en uitvoering van bedrijfsonderzoeken en bevolkingsonderzoeken.

Sedert mei 1979 is hij werkzaam bij het Gemeenschappelijk Administratiekantoor (GAK), aanvankelijk als verzekeringsgeneeskundige, vanaf juli 1982 als adviserend geneeskundige van de districtskantoren Maastricht en Heerlen.

In de periode 1984 - 1986 gaf hij leiding aan de projectgroep Informatieplan Medische Dienst GAK.

In de periode 1984 - 1987 heeft hij het initiatief genomen tot het opzetten van de stage verzekeringsgeneeskunde voor lhuisartsen in opleiding aan de Rijksuniversiteit Limburg en was namens de KNMG lid van de Commissie Postacademiaal Onderwijs Sociale Geneeskunde van de Rijksuniwersiteit Limburg.

Sedert mei 1987 is hij werkzaam als adviserend geneeskundige van het districtskantoor Den Haag van het Gemeenschappelijk Administratiekantoor en had in de periode 1987 $\mathrm{t} / \mathrm{m} 1990$ als projectmanager de leiding van de projectgroep, die belast was met de bouw van het Informatiesysteem Medische Functie.

In 1988 heeft hij in samenwerking met de Basisgezondheidsdienst Zuid-Holland Noord te Leiden meegewerkt aan de opzet van het co-assistentschap Sociale Geneeskunde. 